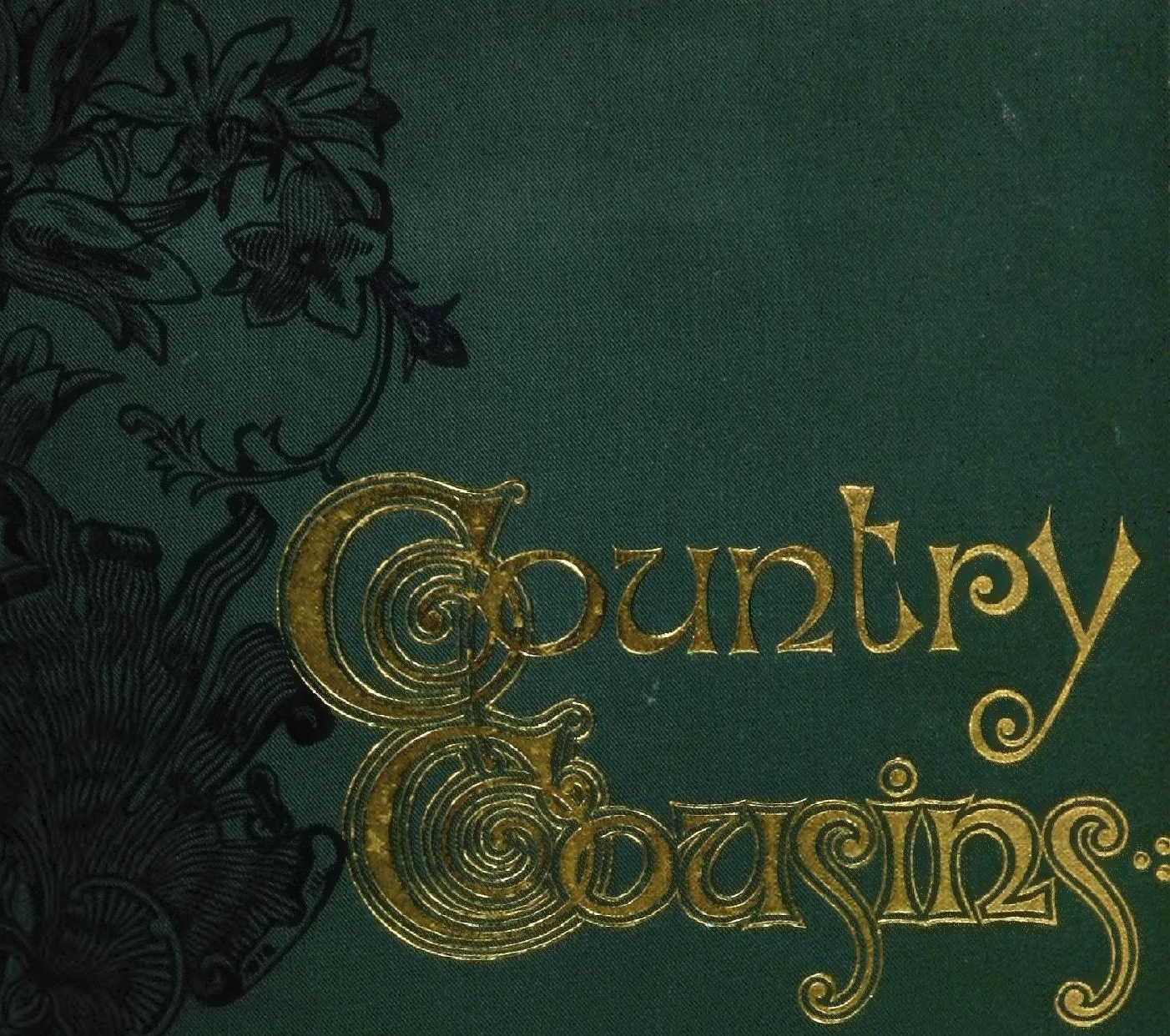

7.5

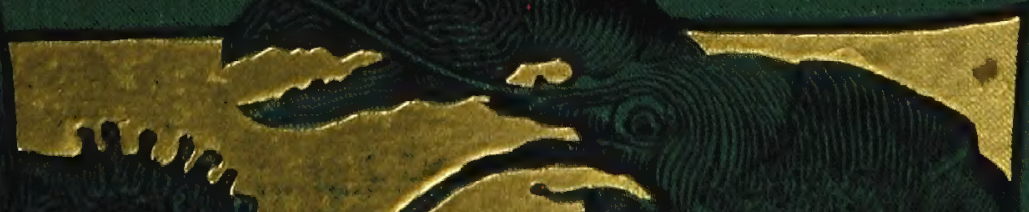




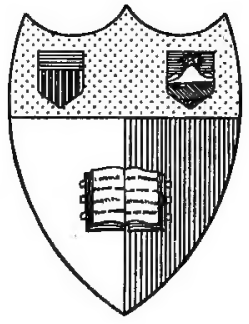

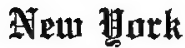 \\ Sitate Gallege af Anrirulture \\ At Gánell Jniumesity \\ Jithara, 赫.}

\section{Jiluraxy}


QL 81.146 ${ }^{\text {Cornell University Library }}$

Country cousins; short studies in the nat

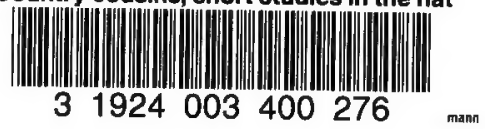




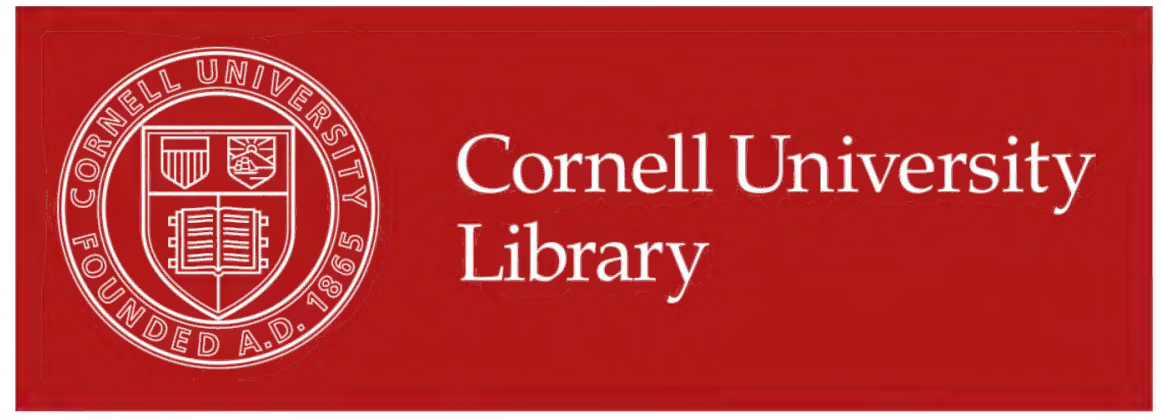

The original of this book is in the Cornell University Library.

There are no known copyright restrictions in the United States on the use of the text. 





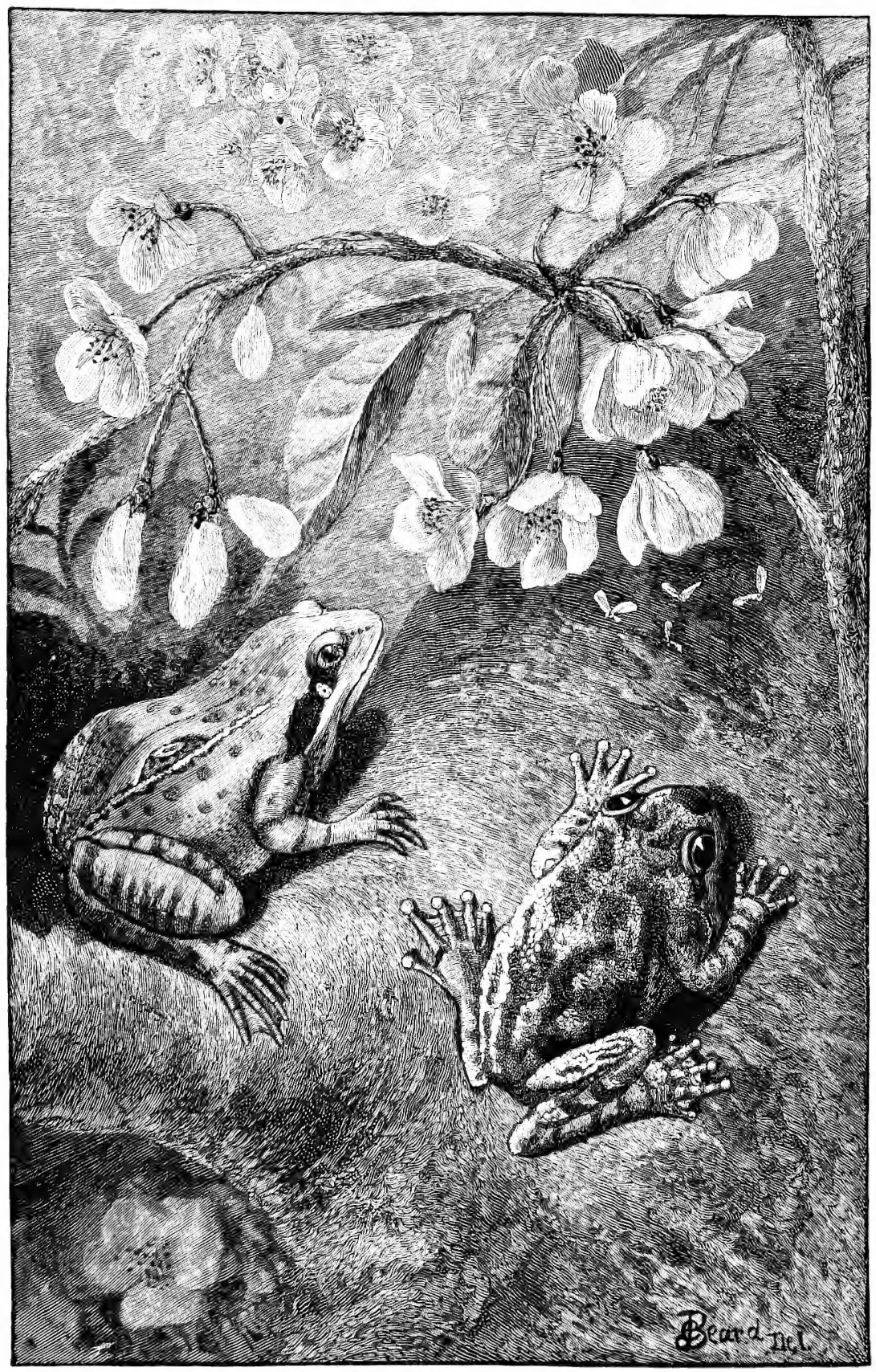

THEE-TONDS. 




\title{
COUNTRY COUSINS
}

\section{SHORT STUDIES IN THE NATURAL HISTORY OF}

\section{THE UNITED STATES}

\author{
BY \\ ERNEST INGERSOLL \\ AUTHOR OF " FRIENDS WORTH KNOWING" "KNOCKING ROUND THE ROCKIES" \\ "THE ICE QUEEN" ETC.
}

ILLUSTRATED

NEW YORK

HARPER \& BROTHERS, FRANKLIN SQUARE 1884 
Entered according to Act of Congress, in the year 1884, by

HARPER \& BROTHERS,

In the Office of the Librarian of Congress, at Washington.

All rights reserved. 
沺edicated

To

MY FATHER 



\section{NOTE BY THE AUTHOR.}

THE substance of the greater part of this book has been printed hereto1 fore in various periodicals, and is now republished by the kind permission of the proprietors of The Century, St. Nicholas, The Manhattan, The American Naturalist, Appleton's Journal, Science Neros, The Field (London), The Current, The Congregationalist, and Good Cheer.

In all cases, however, the articles have been carefully revised, and to some of them extensive additions have been made. It is hoped that the result will contain not only some entertainment, but also helpful suggestions for those who take delight in out-door studies.

New Haven, Conn., August 1, 1884. 



\section{CONTENTS.}

I.

PAGR

My First Tree-chopping

II.

A Wet Day with the Birda . .

III.

The Least of the Mammals .

IV.

Birdg of the Brookside

V.

WINTER WORK FOR NATURALISTS

VI.

A Model Freld-naturalist

VII.

NATURE IN WIITER-QUARTERS .

VIII.

At a Sea-side Laboratory

IX.

Rattlegsatems in Fact and Fanct . . . . . . . . . . . . . . . . . 90

$\mathrm{X}$.

“Mine Orster's" Battle of Life. 
XII.

Periwinkles and Other Orster-pests

XIII.

The History of a Mavgrove Key.

XIV.

The Pompano-shells .

XV.

a Practical View of Devil-Fishes

XVI.

Elk ANTLERs

XVII.

A Сеat abott Bob White. . . . . . . . . . . . . 175

XVIII.

Seals and Seal-hunting in the North Atlantic . . . . . . . . . . . 182

XIX.

The Caverns at Luray and at Pike's Peak . . . . . . . . . . . . 203

$\mathrm{XX}$.

The Abalone and its Utility . . . . . . . . . . . . . . . . 221

XXI.

The Shell-MoNey of the Native Americans. . . . . . . . . . . . 227

$\operatorname{INDEX}$. . . . . . . . . . . . . . . . . . . 249 


\section{ILLUSTRATI ONS.}

TAGE - PAGT

Tree-toads. . . . . . . Frontispiece Bones of the Upper Jaw . . . . . . 103

"Bright Dots of Goldfinches" . . . 15 Relation of Temporal Muscles to the

The Great Carolina Wren . , . . 26 Gland . . . . . . . . . 104

The Retreat of the Towhee. . . . . 29 Oyster's Egg, immediately after Fertili-

Blarina-the Short-tailed Shrew . . . 33

Skull of a Shrew (magnified), showing Character of the Teeth . . . . . 35

Neosorex-the Long-tailed Shrew . . 37

"The Edge of a Brook in the Country" 40

"Pebbly Shallows just above the Cataract". . . . . . . . . . . 45

Brook Blossons . . . . . . . . 48

Moths . . . . . . . . . . 53

Trying its Wings . . . . . . . . 54

The Struggle for Existence in Winter . 59

Thick-shelled Paludinæ . . . . . 62

Partridges in Winter . . . . . . . 69

A Vigilant Hare . . . . . . . . 71

After a Sleet Storm . . . . . . . 73

The Fox's Winter Prey . . . . . . 75

Alexander Agassiz . . . . . . . . . 79

Materials for Laboratory Study . . . $\quad$. 89

A Typical Rattlesnake . . . . . 93

Head of the Copperhead - upper and under views . . . . . . . . . 95

Head of the Copperhead-side and face views

Cranium of Crotalus, with Muscles concerned in the Venom Stroke. . . . 103 zation . . . . . . . . . 113

Egg three Hours after Fertilization . . 114 Egg at a Later Stage . . . . . . 114

Egg in its Final Stage . . . . . 114

First Appearance of the Embryo . . 115

An Oyster One Year Old, showing Embryonic Shell at the Apex, and Lines of subsequent Additions . $\quad .115$

The Slipper Limpet . . . . . . . 118

Star-fishes (lower figure showing under side and ambulacræ) . . . . . 121

Egg of the Star-fish, after Fertilization. 124 An Egg nearly ready to Hatch . . 124

An Embryo Star-fish at an early Stage, seen edgewise . . . . . . . . 124

A more advanced Embryo, swimming by Rows of Cilia along the Protuberances . . . . . . . . 125

A Young Star-fish . . . . . . . . 125

Dining upon an Oyster . . . . . . 129

Reproducing four lost Arms . . . . 133 Shell of Fulgur carica . . . . . . 138

A "Sea-necklace"-Egg-cases of Fulgur 140 Sycotypus canaliculatus . . . . . . 141 Purpura lapillus . . . . . . . . 145 


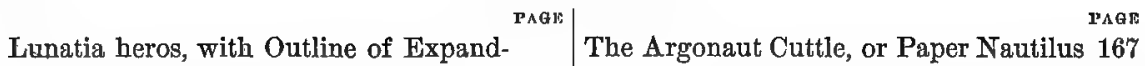
ed Foot. . . . . . . . . . 145

Egg-capsules of the Drill . . . . . 145

Ilyanassa obsoleta . . . . . . 146

Tritia trivitata . . . . . . . 146

Urosalpinx cinerea . . . . . . . 146

Blue, or Soft-shelled Crab-Callinectes hastatus . . . . . . . . . $14 \%$

Common Shore Crab-Cancer irroratus 147

At the Margin of a Mangrove Key . . 154

Shell Mounds, Fort George Island . . 155

Pompano-shells . . . . . . . . 158

Under Surface of the Common SquidLoligo pealei . . . . . . . . . 162

The Giant Squid (Architeuthis) of Newfoundland . . . . . . . . 164 A Wapiti "Bunl" and "Calf" A. Wapiti "Bull" and "Calf". . . . 169 Elk Antlers of Regular Growth . . 171 An Irregular Pair of Horns . . . . 172 Extinct!. . . . . . . . . 174 The Harbor-seal . . . . . . . 183 Panic-stricken by a Sword-fish . . 187 A Harp-seal Mother and her Little One . . . . . . . . . . . 189 The Hooded Seal-Cystophora cristata . 191 Floating on an Ice-pan . . . . . 193 A "Seal Meadow," or Herd upon the Ice . . . . . . . . . . . 195 The Sealing-fleet entering the Ice . . . 197 Dragging Bundles of Pelts . . . . . 200. The Abalone, fully Expanded . . . . 223 


\section{COUNTRY COUSINS.}

I.

MY FIRST TREE-CHOPPING.

. HAVE cut down my first big tree to-day, and am the possessor of 1 my first axe. These two important events came about in this way: Opposite my house is a small grove of splendid trees. One of them, a fine, large, red oak, was badly decayed near the roots, and would surely fall in some high wind next winter. So my neighbor, who is never so happy as when he can get me hard at work ont-of-doors, said he would give me the tree for three dollars, if $I$ would cut it down and bring it across to my own domain without asking any help.

"I suspect there are three cords of wood in that tree," said the Doctor, "and I'll lend you an axe."

I accepted, and this afternoon we went at it.

"I guess we'd better grind the axe a bit," the Doctor remarked, fingering its already keen edge. "A good woodsman always minds that his axe is sharp. I knew a man once who would chop four cords of wood a day all winter long; he never wasted a blow, and each time he struck he half buried his axe, but it was ground every day."

Accordingly, I turned the grindstone behind the barn while the Doctor, in his great green dressing-gown and New Hampshire moccasins, held the axe. By-and-by I began to think he was too scrupulous about that edge, and hinted as much.

"Do you remember Franklin's story about the speckled axe? It is in one of his early letters."

I did not, and the Doctor repeated it. He pointed no moral-he is not the kind of a man to do that-but I kept on turning in silence until he brought the edge to his idea of perfection. Then he swung.it throngh the weeds, and it cut them off as a new sickle might have done. 
The tree was nearly eight feet in circumference, where $I$ was to cut it, close to the ground. It was straight, and pretty tall, but leaned well out over some low, clear ground, upon which I proposed to drop it, or "fall it," as most lumbermen would say, in a confusion of the verbs "to fell" and "to fall." On that side it was very solid, but on the upper side a deep cavity had been eaten in, which I thought would lessen my labor immensely.

Laying aside my coat, I struck a blow at the tough bark; the axe sank deeply through it into the white sap-wood. A second, and a triangular chip flew ont, while a flicker, uttering his shrill, healthy cry, darted from the topmost limb in sudden fright. A third blow easily dislodged a great yellow fragment and seemed to make a big gap.

"Why, this is fun!" I said to myself. "I'll have it down in a few minutes."

But as I got farther into the brown heart-wood the chips grew smaller, and the constantly broadening cut seemed to deepen very slowly. Half an hour passed, and there was no sign of a tremble in the tree, or apparent approach to the hollow heart on which I had counted to help me. It was a cool September day, but the perspiration had by this time started plentifully, and I divested myself of collar and waistcoat. The Doctor lay stretched on the grass near by, his bushy gray head strongly printed against a splendid clump of golden-rod.

"Go on," he said, "yon've done the worst of it. You've got lines to guide your axe now!"

It seemed to me that I needed something more than those lines to make my strokes go true. Nearly half the blows were wasted, becaise I could not hit precisely what I aimed at.' Growing nervous, my axe once shied off and came within a hair's-breadth of laying open my foot. With a sardonic grin the Doctor came to my assistance, and with practised hand cleared up some of the hackings with which I had disfigured the stump.

"I had an uncle," he said, pausing after a little, "who was a famous chopper up in the Mohawk Valley. When he was past seventy, he had a man working for him who thought himself pretty smart, and my uncle offered to 'butt' him."

"What's that?" I interrupted, thinking of negroes and rams.

"In 'butting,' a man proposes to cut off the butt end of a prostrate tree-trunk while his rival is cutting through the diminished diameter at the upper end of a log's length. My uncle beat the workman, in spite of his three score and ten." 
After another spell at the axe, during

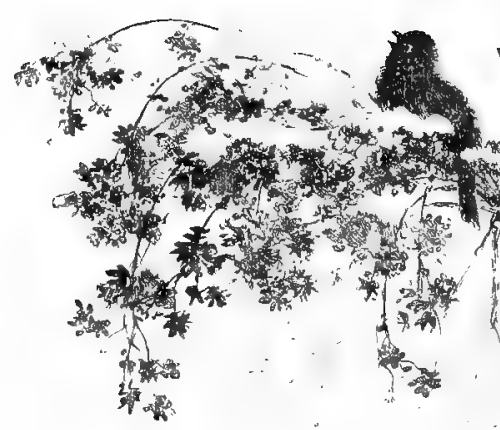
which I began to make two cuts, one a few inches above the other, and to split off the intervening portion, thus saving work, I found my right arm in good shape, but my left al'm very tired, while I could not control the fingers of iny left hand at all, but had to straighten them out one

"BRIGHT DOTS OF GOLDFINCHES,"

by one with the other hand, as though they were attachments quite apart from my own anatomy. A beautiful blister was lising on the ball of the second digit.

Just as I was returning to work, a protuberance on the bark canght my eye. It seemed to be a large cocoon of some unknown moth. Placing my hand upon it, it moved quickly, and I was astonished to find a yellow-breeched tree-frog in my grasp. His back was exactly the color of the bark, mottlings and all, and it was only by chance I had caught sight of him. Ile was finely disguised, and protected against his enemies by his invisible dress-far different from the bright dots of goldfinches, whose gleaming yellow coats I could detect in the thicket a long distance up the hill. This frog's immobility, while his perch was being felled, was a good illustration of the western phrase that describes a man who is stolid, when excitement wonld be more in place, as "sitting like a bump on a log." That was precisely the case with this calm hyla-well surnamed versicolor-whose portrait appears in the frontispiece, beside that of his neighbor the wood-frog. 
Something over an hour had now passed, and the bronze-red pepperidge across the street had become scarlet and royal purple in the fierce light of the almost level sun. The Doctor walked round and round the tree encouraging me.

"She'll come in a minute-in a minute! Hit her again-she hasn't any friends! She's a-coming !"

But, bless you! my repeated whacks, littering the whole neighborhood with chips (which already had attracted a swarm of carpenter bees), seemed to have no more effect than would the cracking of hickory-nuts at the base of Pompey's Pillar. The harder I worked, the more I sweat; and the oftener a blow went wild the more that wicked neighbor of mine hugged himself with glee, and exasperated me by personal remarks and unfounded encouragement.

"All great men," he said, with evenly shared flattery, "have been chopper's. There's Horace, and Gladstone, and Grévy, and Greeley, and-"

"R. B. Hayes," I interrupted. "Go on-pretty soon you'll disprove your own statement."

"Oh no," he answered, unruffled, "you and I are enough to keep up the average. Now, Brother I.," he continued, changing the subject, "I've another idea. You see those trees over there? I have just bought them."

He pointed to another part of the grove where four great trunks diverged from the same root. They were oaks of huge size and fine symmetry, and had been highly prized by every one near, until some angelforsaken miscreant kindled a fire in their midst and burned the heart ont of the whole group. That man will be hanged yet if Nature has her dues! Now that they had become feeble it was necessary to take them down, in order to save their crushing other ornaments of the bosky knoll by an unguarded fall.

As I carefully straightened out my nerveless fingers, and slowly unbent my stiffened arm, I replied, "What of it?"

"This," said the Doctor. "I'll give you those four big trees for eight dollars if you will remove them."

"I won't do it," I said; "but I'll tell you what I will do. I'll give you six dollars for the trees, and then I'll give you half the wood, if you will place the other half, piled up, in my back yard."

He smiled blandly; but declined. That man don't know a good bargain when he sees it.

It was now nearly two hours since the work had been begun, and I was getting tired. What sufferings Robinson Clusoe must have had in 
hewing down the great tree for his boat; and how the red men must have toiled with their old stone adzes to fell the big logs they needed for their dug-outs! I never understood it before. The hollow heart of this oak was a frand. It is a frequent occurrence to think a tree sound and find it rotten; but to think it rotten and find it sound is a thousand times worse. I was a victim of misplaced confidence. At last, however, I thought I had gone deep enough into the undercut, for the gash yawned like a grave, and there seemed to be several bushels of chips. Whether, however, I should have had the pluck to treat myself to a fair rest is uncertain; but I was saved the trial, and given the needed recreation, by the occurrence of an incident which took us to another part of the grove, and taught us a new lesson in brute kindliness-words that seem to contain a paradox only because we have allowed a perverted notion of things to possess our minds.

Upon the large estates in the eastern part of the city are enclosed groves of oak, hickory, chestnut, and other mast-bearing trees-the "Sachem's Woods" of the poet, James Hillhonse-where many gray squirrels rear their families in almost entire security.

For the dozen or more pairs that inhabit our particular grove the Doctor had put boxes in convenient tree-crotches, which the squirrels at once took possession of. He also hoisted a suspension-bridge between two large trees much frequented by them, and we all have derived a great deal of amusement in watching the antics of the little fellows upon this aerial road. It is sixty-five feet long, swings about twenty feet above the ground, and consists of short poles, wired into a cable.

Some families of squirrels, however, live in another grove beyond the fence, and make nests in wild fashion of leaves and twigs, lined with leaves and shredded bark. This grove is open to the public, and there the squirrels suffer in spite of all onr vigilance: only a small portion of humanity have become civilized up to the present time.

Just as I was giving the last stroke to the finished undercut, I saw my friendly monitor spring to his feet and hasten towards a boy who had just come from the farther grove. Underneath the boy's coat could be heard faint squeakings, and pouncing upon the frightened youth the Doctor claimed and instantly received two young squirrels, while the plunderer took to his heels with the greatest alacrity.

The little rodents were now in the hands of a well-wisher, but they were orphans and homeless. What could be done with them? In size they were half as large as the adults, but they had hardly been weaned, and were totally innocent of the world. Bronght into my friend's big 
yard, as the first step towards help, one of the rash pair darted from the Doctor's gentle grasp, and scrambled up a tree to the first crotch, where it lay liugging the limb.

With the other we walked towards the house. It uttered frequently a piteous little $\mathrm{cr}^{\mathrm{y}}$, and this attracted in an instant the attention of a mother squirrel, who, with her half-grown family, occupied a box in the oak. She rushed out in a flurry of excitement, and hastened down to the bridge, where, as the Doctor came underneath, she seemed almost ready to jump down upon his shoulders, so great was her distress at the wailing of the frightened youngster he carried.

Thinking he could do no better, he placed the little one on the ground, and we retired to watch what might follow. As soon as the old squirrel saw him do this (the whole agile tribe have become very tame towards us) she ran swiftly down the chestnut-trunk to the ground, and thence to the side of the lost infant, which she could not find in the tall grass without standing on her hind-legs two or three times, and gazing carefully around.

No sooner was the orphan discovered than the motherly heart of the old one decided to take it at once to her own home. Putting her arms abont it in the most touching way, she spent a few seconds by its side, and then trotted off, bidding the stranger follow. But the grass was tall, and the little one was timid. Again and again it would lose the way or give up, requiring the older one to go back and call to and encourage it. Finally, the base of the chestnut was reached, and the ascent of its broad trunk and great out-stretching branch was an easy task.

Here, however, an immense difficnlty awaited the anxious mother, and a seemingly impossible task confronted the timid foundling. Out beyond the broad avenue of the chestnut-limb stretched the slender pathway of the long bridge, with its steep slope at the other end, npward to where the snug haven of "home" nestled invitingly in the lofty oak. To an adult sciurus, leaping from spray to spray among the topmost twigs of the tallest trees, this was the most pleasant and easy of runways; even to Mother Squirrel's half educated bairns, one of which now sat almost invisible upon the roof of its box watching the proceedings with curious black eyes, this bridge had lost its terrors, for they had practised it by easy stages under parental guidance; but for the baby so rudely thrown upon its own resources, that wavering cable offered too thin and dizzy a foothold to be thought of for a moment as a means of transit, however alluring might be the prospect at the other end.

There was a pause. The old squirrel ran nimbly out a few feet and 
looked back. The trembling youngster had not followed. She called to him in low chatterings, but he did not dare to forsake the security of the big limb. Then she went back and caressed the small stranger. One can imagine all the fond, re-assuring things she said to him, squirrel fashion, while she licked his ruffled fur and quieted lis fears. The delay was so long that we began to fear she would fail, but presently she marched slowly out on the bridge, looking over her shonlder, and the young one timidly followed, creeping with great caution and fear.

Seemingly everything was going well, but in the middle of the bridge the little fellow's courage failed, and all the old gray's coaxing could not induce him to take another step. She was by no means at the end of her resources, nevertheless. Darting across to her house, she came back with one of her own children, and introduced him to the terror-stricken little orphan. "See!" she said to it, in effect, " here's a kitten not much bigger than you, who can run along the bridge as fine as anything. You need only to be brave." Thus stimulated, the foundling made a desperate attempt to go on, attended and coaxed by its two hosts. Once it faltered, and then the mother squirrel tried a final expedient. Stretching her legs wide apart, she placed herself completely over the young one's flattened body, holding it on, as it were, and moving along with it as it crawled forward, until the pluck of the baby revived; the last quarter of the bridge was more nimbly traversed, and the safety, warmth, and, doubtless, food of the new hospice were gained.

Subsequently we caught the other orphan and carried him to the root of the oak, where he was invited to share the same hospitality without having to pass the ordeal of the bridge.

This incident seemed remarkable to us who witnessed it.

In the first place, that a squirrel should exhibit so intense an anxiety at distress ontside her own circle, and slow so genuine and persistent a desire to give aid, ending in adopting two outcasts without hesitation.

Next, that she should show so much sagacity in accomplishing this kind purpose. Her patience in leading the nervous little stranger along through the grass and ont npon the bridge seemed inexhaustible. When she found that it was too timid and inexperienced to cross the long cable (for squirrels must learn to climb as seals learn to swim and men learn to walk), it was a mancuvre dictated by little less than reason to bring her own kitten as an example of what little squirrels, as well as big, might do, if they had enough resolution. So far as we conld see, all her coaxing and aid would hare been futile had not this last expedient been brought to bear. 
Meanwhile my tree was only half severed. Returning to it an incision was begun on the upper side. I had been solicitous about the straightness and smoothness of the undercut-that the "corners" should be squarely at right angles to the line of fall, etc.; but I gave all that worry up now, and cared only that somehow the tree should be got down. The scientific work I had seen in the great red-wood forests of California might apply here, or might not; I didn't care. So long as the Doctor lay idly gazing at me with an amused smile, I was anxious only to bring that obstinate oak to the ground as speedily as possible. But this uppercut I had thought would be so easy proved another frand. The decayed part of the wood was only skin-deep; under it lay a mass, dead, to be sure, but hard and dry-nearly as tough as iron. I chopped at it until I was nearly ready to drop with fatigue.

"Don't work so rapidly," my monitor called out; "you should strike no faster than you can keep up all day, never stopping to rest at all."

At last, however, there came a faint cracking sound of overstrained fibre. I jumped back, but the tree stood there, its great green head rustling unconcernedly as of old. "Keep at it," said the Doctor, and I did so, working with exasperated energy at the points I thought gave the strongest support all around the trunk. Fibres cracked, but there was no shivering for a long time. It was astonishing how that enormously heavy, far-leaning, mass of wood aud foliage held its erect position. Finally, a sharp report of rending tendons was heard-a sudden lurch of the topmost boughs was seen; then a second's pause, as though the giant was about to recover itself-a slow swaying forward-a swiftly-gathered force and unotion-a tremendous, swinging crash to the shaken ground.

The tree was down, and I climbed upon the log with intense satisfaction.

"I must buy an axe!" I exclaimed, feeling that whole forests were ahead of me.

"There is one," said the smiling Doctor, picking up the tool I had just thrown aside, "for which I paid one dollar and a quarter. What will you give for it ?"

"Seventy-five cents," I answered.

"Done!" said he, and handed it over.

"Now you will get a new one," I remarked.

"Perhaps so-by-and-by," he replied, slowly, with that provoking twinkle in his eyes; "but as you have been borrowing mine for a while, I think I'll borrow yours when I want one this winter-eh?" 


\section{II.}

\section{A WET DAY WITH THE BIRDS.}

\section{D}

$\mathrm{OWN}$ in Virginia I was once delayed four hours at a little railway junction right in the woods. It was June, and so onght to have been sunny, but, on the contrary, the air was chilly, the sky was covered. with heavy clouds, and now and then came dashes of cold rain. This is by no means the sort of weather birds feel gay in, and when they are chilly and blue, they are no more likely to sing with spirit and move in a sprightly way than are we ourselves. Certainly it was a poor day for ornithology, but I started down the track to see what I could find, and discovered a few of this race of my country consins abroad.

The first one I met was a yellow warbler, showing his salmon-striped vest very plainly, but keeping very quiet. Then I struck a bunch of sparrows, which are always great favorites of mine. There were two or three song-sparrows and half a dozen chippies, or hair-birds, as they are sometimes called in New England because they nse so much horse-hair in building their nests. The chippies kept down near the ground, running through the grass, and in and out between the mossy rails of the fence, but the favorite perch of the song-sparrows was high up on the telegraph wires. I watched one a long time. He sat there right through a shower, and fairly spouted his short but most musical song, the black patch on his spotted breast (by which you may always know him from the other streaked sparrows) rising and falling as he sang in a way plainly visible to me as I stood down on the rails. His ditty, often repeated, was precisely the same every time, except in the introductory chatter, which was cut short now and then, as though he couldn't wait to give the prelude before letting you hear the varied notes to follow. Some other songsparrows not far away sang in a decidedly different way from him, though evidently attempting the same tune; and I should say there was as much variety in their voices as among the girls and boys in a school-room.

Every now and then the sparrows would fly down into the brush and grape-vines between the track and the fence, and stay a little while, prob- 
ably hunting for food. They would disappear under the foliage, but in half a minute were ont again, peering around to see that no danger was near. This incessant vigilance is very characteristic of all birds whose way of living brings them close to the ground, where enemies are liable to be lurking. No matter how quiet and safe all appears, they stop work every few seconds to stretch up their heads and gaze anxiously around them, flirting their tails and half lifting their wings as though ready to take instant flight. This constant half-decided terror influences their whole lives, and the cat which catches a bird must be stealthy and quick,-hence of course they are so.

Another busy and garrulous little group at the junction was formed by a pair of great Carolina wrens, a bird that unfortunately the Northern States cannot count on their lists, except as a rare stranger. In the middle districts, however, it is an annual visitor, if not a permanent resident, for as far north as central New Jersey and southern Ohio they not only breed every summer, but remain through the coldest winters.

About the rocal powers of this wren much has been said and written. That little fellow to which I listened on the occasion I am speaking of trilled a song all his own--a loud, rollicking warble, not at all like the exclamatory roundelay of his neighbor the sparrow, which was full of Polish kats, utterly unpronounceable withont a twist and snap of the voice that nothing less slender than ä bird's tongue or a whip-lash conld hope to produce. But in addition to this music of his own composition, he is credited with powers of vocal mimicry-with being an accomplished and tireless imitator of woodland melodies, and is more often called the mocking wren than by any other name.

In the elaborate "History of North American Birds"-which ought to have filled "a great want," but failed to do so, apart from its technical half-the late Dr. T. M. Brewer makes this statement in respect to the Carolina wren: "This species possesses a great variety and power of song. It is also said to have and to exhibit remarkable powers of imitation, with a great variety in its appropriated notes of other birds, giving, with modulations, the hoar'se rattle of the kingfisher, the lively notes of the tufted titmouse, the simple refrain of the ground-robin, with those of the gralkles, the meadow-lark, the bluebird, and others."

- Now where did Dr. Brewer get this information, and how did the reputation become fastened upon the little bird? for certainly there is no good evidence to be found in the writings of modern observers that this wren ever truly mimics the voices of other birds, as do the mockingbird, the cat-bird, the sage-thrish of the Rocky Mountains, and some others. 
Alexander Wilson's testimony is as follows: "It occasionally utters a loud, strong, and singular twitter, resembling the word chirr-rup, dwelling long and strongly on the first syllable, and so loud that I at first mistook it for the redbird ( $L$. cardinalis). It has also another chant, rather more musical, like 'Sweet William, Sweet William,' much softer' than the former."

Audubon seems to regard the habit of singing from the roof of a flatboat on the river as the most noticeable point of its vocalism.

None of the more modern biographers of the bird, as I have already hinted, enlarge upon this alleged power; in fact, it is not mentioned at all by them.

In his admirable "Birds of the North-west," Dr. Elliott Coues gives us a charming account of the bird, dwelling on its voice. "It frequents shrubbery," he writes, "and undergrowth of all sorts, where it hides with great pertinacity, and is oftener heard than seen. Not that it is purticularly a timid bird, for it often comes about the gardens and out-houses; but it is retiring and unfamiliar, courting privacy and seclusion. If we attempt to penetrate its hidden resorts, it hurries away into deeper recesses, with a low fluttering near the ground, or scrambling and hopping from one bush to another, very likely mocking us with its rollicking song as soon as it feels perfectly secure. It shares, however, the restlessness and prying curiosity of its tribe; and if we keep still in a favolable spot we may often see it returning slyly to take a look at us, peering from among the leaves with an inquisitive air, all the while 'teetering' its body, and performing odd, nervous antics, as if it were possessed with the very spirit of unrest. At such times it chatters in a harsh, querulous tone, as if resenting the intrusion; and this is its ordinary note when angry, alarmed, or otherwise disturbed in mind. Its song is quite another thing-loud, clear, strong, and highly musical; indeed, I hardly know what bird possesses a richer voice, though many are sweeter songsters. The song is a rapid sncession of whistling notes, delivered with great energy and accent; it closely resembles that of the cardinal grosbeak, styled in some parts the Virginia nightingale, and meriting the compliment. In still weather the wren can be heard several hundred yards, but it is not easy to trace the music up to its source, because the resonant quality of the notes makes the whole copse seem to ring with the sound, and because the restless songster is constantly changing his position."

Of the many men who have given us "local lists" of the avifauna here and there in the Southern States none bring forward different testimony. In the gathering of the material for one of the most extended of 
these pamphlets, I had a part: I refer to Mr. William Brewster's paper in the "Annals" of the Lyceum of Natural History of New York City (now the Academy of Sciences), vol. xi., June, 1875, pages 129-146, on birds observed in Ritchie County, West Virginia. The memoranda of Mr. Brewster, Mr. Ruthven Deane, and myself (in my case combined with notes made during previous visits to the same locality) were united in this paper. None of us could hear any mockery in the little bird's vivid and always entertaining concert, from which the cat-bird was not slow to enrich his plagiarized repertory. "The song of the male," Mr. Brewster recorded, "is a beautifully clear and pure one, but it is so always and invariably the same [the italics are mine] that one soon tires of it. Heard in some deep, silent glen or ravine, its loudness is positively startling, the rocks taking up and flinging back the sound till the air is fairly filled with the ringing melody."

Lastly, in an extremely interesting paper on this species, contributed to The American Naturalist for January, 1884, Dr. C. C. Abbott describes the year's life of one of these wrens that took up its atoode most familiarly upon his farm near Trenton, N.J. In regard to its voice, Dr. Abbott remarks: "Carefully as I have listened to this wren for a year, I have never heard a note that I should consider as not its own, and not borlowed."

Evidently Thomas Nuttall is responsible for this wren's reputation as an imitator: "remarkable, mimicking, and musical," he calls the bird, and devotes nearly the whole of his biography to a graphic representation of the wren's striking gifts in this direction.

By means of those queer phonetic syllables of which Nuttall was so fond, he strives to describe in succession the way in which the bird recalls the kingfisher, the tnfted titmouse, "his industrious neighbor the ground-robin," the "tremulous trill of the pine-warbler," the blackbird, and several others, many of which had not returned from the far South at the early season when $N$ uttall became acquainted with onr subject; so that, as he says, the notes "would appear to be recollections of the past season." None of the examples given are more than a few notes here and there, brief snatches of the songs of the varions birds, which, I should say, were suggested rather than imitated; but it is stated that once the squalling of a child in a cottage was mimicked by a wren at the door. Let me quote a paragraph from Nuttall's charming story:

"Amidst these imitations and variations, which seem almost endless and lead the stranger to imagine himself, even in the depth of winter, surrounded by all the quaint choristers of the summer, there is still, with our capri- 
cious and tuneful mimic, a favorite theme more constantly and regularly repeated than the rest. . . . This sweet and melodious ditty, tsee-toot tsee-toot tsee-toot, and sometimes tsee-toot tsee-toot seet, was usually uttered in a sornewhat plaintive or tender strain, varied at each repetition with the most delightful and delicate tones, of which no conception can be formed without experience. ... In most cases it will be remarked that the phrases of onr songster are uttered in $3 \mathrm{~s}$; by this means it will generally be practicable to distinguish its performance from that of other birds, and particularly from the cardinal grosbeak, whose expressions it often closely imitates both in power and delivery. I shall never, I believe, forget the soothing satisfaction and amusement I derived from this little constant and unwearied minstrel, my sole vocal companion through many weary miles of a vast, desolate, and otherwise cheerless wilderness. Yet, with all his readiness to amuse by his Protean song, the epitome of all he had ever heard or recollected, he was still studious of concealment, keeping busily engaged near the ground, or in low thickets, in quest of food; and when he mounted a log or brush-pile, which he had just examined, his color, so similar to the fallen leaves and wintry livery of nature, often prevented me from gaining a glimpse of this wonderful and interesting mimic."

With all respect to $\mathrm{Mr}$. Nuttall, I cannot but believe that the peculiar circumstances under which he listened to the song of the Carolina wren influenced his imagination too strongly. Undoubtedly, one may hear in its loud and extremely varied nuptial song many notes that, singly, might suggest the elements and the quality of the songs of various other birds; but it is my opinion that if these are ever voluntarily produced by the bird outside of its own native song, as imitations, the instances are far less rare than Mr. Nuttall's enthusiastic and sentimental description would have us believe. The song of the wren is "Protean," truly, but, generally speaking, I do not believe it is mimicry in the proper sense of the word.

They were as active and inquisitive-my pair of Carolina wrens-as any of their excitable race. A bridge which carried one railway over the tracks of another formed their favorite perch, and I suspected that they had their nest stuffed into some cranny among its braces, but I could not find it, and it may have been behind one of the loose clapboards of a tumbled-down shanty not far away. While I was searching, the wrens became greatly excited, flitting about close to me and scolding much like angl'y kittens. "If shot at and missed," says Brewster, in the paper I have referred to, "they seemed at once to become very angry, hopping nimbly from twig to twig with tail erect, and uttering, almost incessantly, 
a shrill chirr-ree, chir-r-r, chir-r-r, chirr-ree, and occasionally a harsh chatter."

Evidently the small songsters enjoy hugely what they do, and you can fairly see the notes bubble out of their swelling gray bosoms, like water

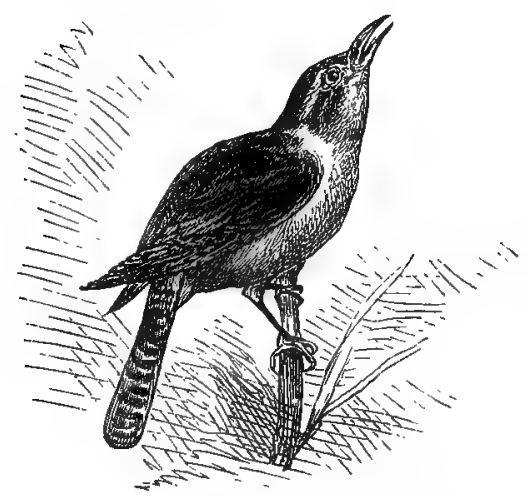

THE GREAT CAROLINA WREN. in a spring. Audubon's picture of one of them, standing. with outstretched head and bulging throat, always seemed an exaggeration until I saw the living bird. I do not know a louder singer than this wren, notwithstanding lis diminutive form; indeed, size has nothing to do with power of voice in birds-witness the noisy music of the pigmy kinglets.

They have long, curved bills, serviceable in picking insects out of crannies abont old wood-work, and out of the bark of trees or off the ground and leaves. I never saw one of them catch an insect on the wing, and I fancy their fare is mainly made up of a variety of helpless grubs.

Here were robins, too.

It is one of the good points of the robin that he sings when the weather is cloudy rather more than during sunshine, and you hear all day the fine music which in cloudless weather he reserves for the evening time of shadows. Two or three of them were now tuneful in an orchard near me, and once in a while I wonld catch sight of a meadow-lark or a grass-finch hovering uncertainly over the sodden fields, as thongh disliking to drop into the wet grass. From the woods, half a mile away, carne the cawing of crows and the complaint of a very melancholy dove indeed-a mournful croon which many persons mistake for that of an owl. Down in the ditch beside the track an orange-vested barn-swallow was taking advantage of the moist condition of the soil to gather mud for his nest somewhere in the neighborhood. Some of this he rolled with his bill into little pellets for the "bricks" of his structure; some he kneaded with bits of grass into small lumps, which he carried away grasped in his claws.

Occasionally an azure spot against the leaden sky showed a blue-bird sitting silently overhead, and I thought of Mrs. Whitney's poem, begin. ning, 
"Little birds sit on the telegraph wires,

And chitter and flitter and fold their wings;

And perhaps they think that for them and their sires

Stretched always on purpose these wonderful strings."

Between the showers one of those royal fellows, the king-bird (which Southern people call "bee-martins"), came over the ficlds with a selfconfident swing in his flight, and alighted on a sapling. He had stood there not a minute - no, not half a minute - when up sprang my two wrens from their perch on the highest beam of the bridge, and dashed at him like little furies. The surprise and impetnosity of that attack was too mnch for him, and though he asserted that more than once he had driven the miglity eagle to find safety in the clouds, yet these little tormentors upset his courage, and he fled as fast as his wings conld carry him. The wrens, still unsatisfied, rushed after, and I could hear the sharp snipping of their bills, like the quick shutting of scissors. It must have sounded very terrible indeed to the poor king-bird, for the pursners kept close to his ears in spite of all he could do.

It seems to be almost a law among birds that their "spirit" is in direct proportion to their littleness. Warblers, kinglets, and wrens are all plucky and pugnacious, while the daring courage of hummingbirds has often been marked with surprise by those who have studied them. They will fight anything whatever that interferes with them, and dart with such lightning rapidity at the object of their hatred, picking at the eyes with their needle-like beaks, that they drive away the enemy by small but persistent torments as effectually as. if they did it by force. Nor is this a useless quality in the least of the feathered host, for he has to defend his home quite as often, probably, as his larger associates.

In the case of many of the hummingbirds, the nest is tucked into a little bag formed by folding over the edges near the point of a long, drooping leaf. This makes them inaccessible to most enemies, and very secure. Other species place their homes in a crotch of a bush between upright twigs; while the ruby-throat-the

"Bright little, light little, slight little hummer, Lover of sunshine and lover of summer,"

who visits the "odorous bowers" of our northern greenhouses and gardens--constructs a.cup of vegetable shreds, matted and glued together, with a downy bed within, and saddles it npon the upper side of a limb of some orchard or forest tree. Only about twice as large as a thimble, and covered with wood.lichens and bits of green moss, it looks so very 
much like an old knot, or scar, or excrescence on the bark, that few persons-provided they canght sight of it at all-would think of its being the home of a bird, unless they happened to espy the owner entering or leaving it.

But in spite of the great care with which this tiny dwelling is hidden, snakes' sharp eyes sometimes find it, as they do the nests of almost all other birds, and they stealthily crawl out on the bending branches, grasping stronger ones with their tails, lest the slenderer supports should break, until they are able to devour the callow young, or to suck the eggs.

Frequent contests between birds and serpents, in which the reptile sometimes comes off victor, and afterwards eats the bird, have given rise to a widespread notion that the snake's eye has a singular and irresistible influence over most small birds, causing them, in spite of every effort, to draw nearer and nearer, and at last fall senseless into the reptile's open jaws. It has even been said that our common blacksnake "draws" catbirds down from the tops of tall trees to certain death, by a charm which they had no power to break; and other incidents, equally hard to believe, are told of the fascination of a serpent's eye. The older these tales are, the more they savor of the marvellous; for they began to be believed long before any books were written. At last the ancient poets imagined an animal called the basilisk, or the cockatrice, as it is translated in the Bible. They described it as born from an egg laid by a very old cock, and hatched by a reptile. In general shape this fabulons animal was like a chameleon; but it had a head and eight feet like a cock, and short wings on its shoulders. Its very presence was fatal to all other animals, including man; its breath poisoned the air, and its glance was death. Presently sceptics began to deny, one by one, these malignant powers, since few fatal cases could actually be traced to that source, until at last the basilisk was bereft of all except the fabulous power to lure any animal to destruction by the fascination of its glittering eye. 'This idea survives even to this day. People who believe that the really rather dull eye of the blacksnake, or rattlesnake, or tiny grass-snake can charm an active bird into dropping into its jaws, conld have believed easily in the griffins and harpies, coquetting sirens, and incombustible phœnixes of the old Greeks.

At the same time there is a grain of truth in each of these marvellous tales of imaginary animals and their deadly qualities. The bird knows perfectly well the danger which lies in getting too near that gently waving head, with its gleaming scales and flaming tongue; it knows the power of that snake to spring at it and strike it a fatal blow; and the 
mere presence of the terrible danger might be so attractive to the bird that it would venture too near, and so fall a prey to its recklessness. Love of danger for its own sake is certainly a characteristic of many men, and some do not seem able to resist encountering the greatest risk, and doing themselves positive larm, for no reason except that they have a good opportunity. Many persons commit snicide, doubtless, under the same strange longing to throw one's self off some precipice, or into deep water, which most of us have felt when standing on the top of a big building, or close to swift and turbuleut rapids, like those at Niagara.

It may be that the fearful peril-and there is no danger a bird can better appre-
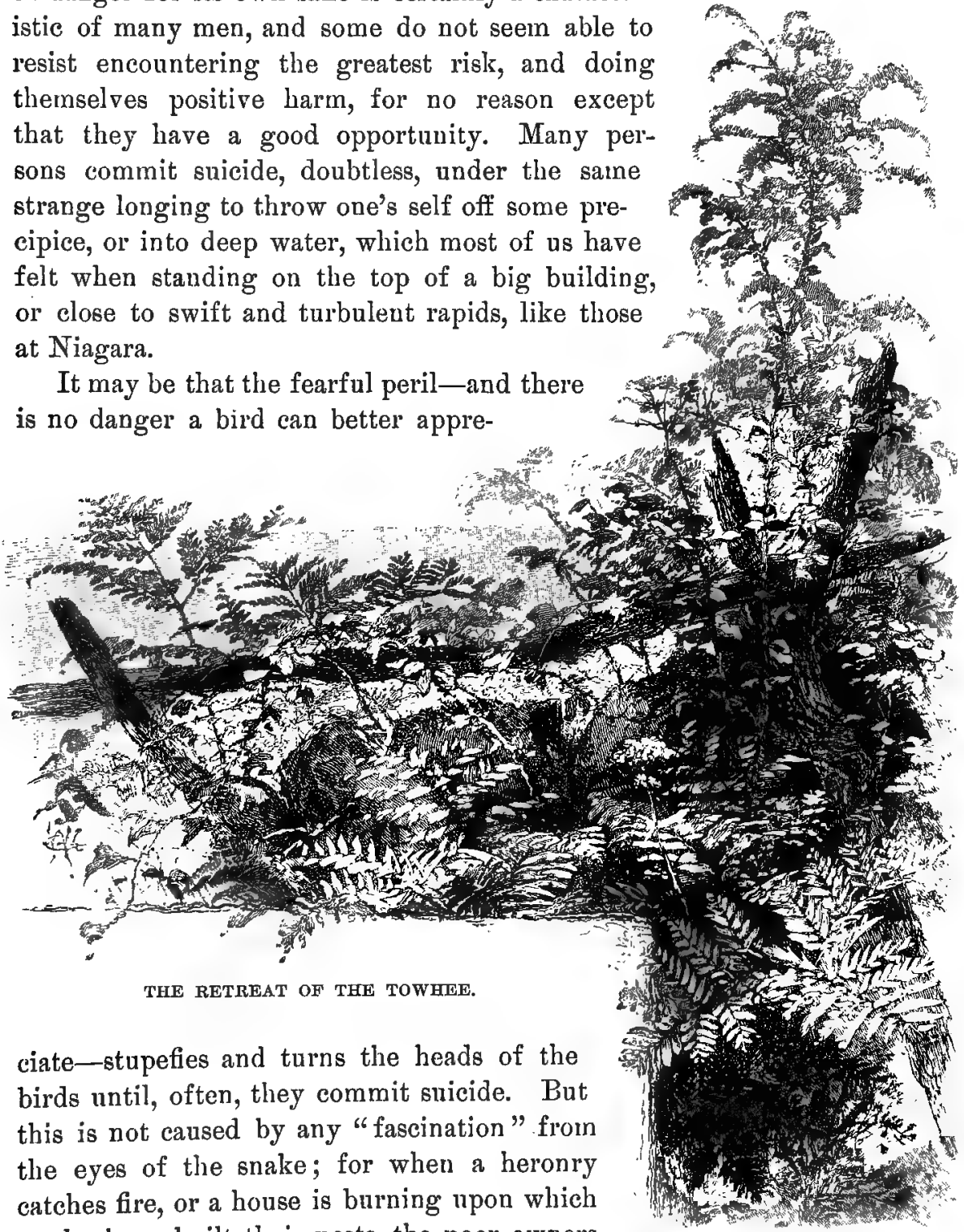
storks have built their nests, the poor owners will fly round and round in the smoke and flame, as though they found it impossible to leave the spot, until they fall dead; and sometimes when 
the Carolina marshes are flooded by gales driving the water in-shore, the rails will seem to become perfectly crazy, and insensible of all other harm, through their anxiety for the safety of their homes. Bnt I need not dwell longer on this topic here, since it is fully discussed in an ensuing chapter on the rattlesnake.

In general, snakes have little the best of it in a fight with their feathered foes. More than once, it has been asserted, a single pair of mockingbirds has killed a large blacksnake that liad insinuated itself into the bush in which their home was situated. Whenever the ugly reptile is so discovered, the male mocker darts upon it with the speed of an arrow, dexterously eluding its bite, and striking it violently and incessantly about the head. The snake soon perceives its danger, and seeks to escape; but the intrepid father redoubles his exertions, and even after the snake has reached the ground, and its strength begins to flag, the mockingbird seizes it, and lifting it partly from the ground, beats it to death with his wings. Cat-birds and brown thrashers will protect their nests, and deal vengeance upon the robber in the same fashion.

Just as I was turning back, a snarling tow-wée struck my ear with startling distinctness from a half-ruined fence where ferns and golden-rod were graciously entwining their lovely plumes. This noisy finch is the prince of skulkers, keeping ever under piles of brush and fallen trees, about the roots of the densest thickets, scratching furiously among the crisp dead leaves for the luckless worms and bugs that lurk there, or the seeds which have rattled down. It is very strange to sit quietly down where the underbrush is thick, and listen to the swamp-robins. Their wings do not make the audible flutter of the sparrows, and you only hear a little stirring here and there that you cannot at all tell the sense of till the bird shows himself, silent, but alert, and full of curiosity, venturing closer and closer with an unconscious, preoccupied air which is intended to disguise his extreme interest in you. Meanwhile you can easily note what a handsome fellow he is. His head and throat all around, back, wings, and long tail are black, the wing quills tipped, and the tail broadly edged, with white; the sides, meeting on the breast, are bright bay, which on the belly and vent becomes rufous-white. In the fomale the black is replaced by light reddish-brown.

Nearly as large as a robin, and red-breasted, he is often called the "swamp" or "ground" robin. The western name, "skunk blackbird," alludes to his varicolored coat; "chewínk," "towhée," "joreee," and similar words are derived from his call, never heard except when he is upon the ground; while the technical name is Pipilo erythropthalmus. 
I have called him a skulker, but when comes the "harvest-time of love" he mounts to the top of some towering tree and sings, ecstatically-

"A song of joy, a song of bliss,

Passionate notes that clasp and kiss."

It is a delicate tune, and all the more so that we hear it during only a short season, though it is performed for hours together, almost without cessation, during the time of his wooing, and is always given from a tree-top-never from the ground.

Soon the shy mate responds, and the pair sink happily into some thicket to finish their courting. There, late in May, they go together in search of a home. The site chosen is usually the bank of a stream, or a wet place in the woods, where they have the company of waterthrushes, ground-warblers, and swamp-sparrows; and the large, comfortable nest is cunningly concealed on the ground at the foot of a little brier, or under a shelving rock, where we should never find it except by one of those lucky accidents which the suceessful ornithologist learns how to induce. The eggs are somewhat larger than a bluebird's, porcelain white, spotted everywhere with reddish-brown, but chiefly in a wreath round the large end.

The chewinks stay with us till the middle of October, and then move slowly south, the feinales and young going first, contrary to advance in the spring, when the males are ahead. Audubon remarks that the migration is performed by day, from bush to bush, and that they seem to be much at a loss when a large extent of forest is to be traversed.

I have let my pen run away now and then from the straight line of the rails along which I walked; but these are some of the things I saw, and the thonghts they suggested while I was waiting for that belated train in the Shenandoah Valley. The hours had passed quickly to me, though I heard plenty of grumbling from fellow-passengers, who knew not my good friends in the thickets. When at last we embarked, and rushed past the old bridge and weedy bank, it was to me alone, I fancied, the full-throated wren, high on his perch, was singing a gay good-speed, and the chewinks nodded their cheering " ta-tas." 


\section{III.}

\section{THE LEAST OF THE MAMMALS.}

$\mathrm{L}^{\mathrm{n}}$ IFTING up a large, flat stone at the edge of a piece of woods, in search of snails, not long ago, I caught a glimpse of a small duncolored animal, not much larger than my thumb, which darted away in precipitate alarm, nttering a squeaking cry. The ground under the stone showed a net-work of little troughs or channels, meeting in a larger avenue at the centre. Down one of these, which at the distance of a few inches disappeared in a tunnel under the matted leaves and herbage, the tiny quadruped scampered to some safe retreat beneath the roots of a beech. I made a catch at him, and, though I missed him, saw that he was a shrew-a scion of the ancient lineage of Soricidæ.

These smallest of all the great company of mammals conceal themselves from the student with true coquetry, baflling nearly all his efforts to get a glimpse of them. Nevertheless they are widespread, numerous, and sometimes familiar, occasionally making their home in the wall of a house-cellar or about the barn.

In color and form the shrew suggests a house-mouse, but his nose and teeth declare him of the entirely different race of Insectivora- a companion to "the moles and the bats." No part of the world (save, possibly, South A merica) seems to lack representatives of the shrew family, but its stronghold is in northern regions. America owns a dozen or so doubtfully defined species, grouped by Coues into three genera-Neosorex, Sorex, and Blarina. In the tirst the feet are fimbriate, and the tail equals or exceeds the head and body in length; the second genus has ordinary feet, and a tail shorter than the head and body; the third lacks visible ears, and has a very short tail. To Blarina belong the greater number of American shrews, and the most diminutive-some full-grown specimens, tail and all, measuring less than two and a lalf inches in length. The bulk of body in the largest member of the family would not greatly excel this pygmy, though the long tails of Neosorex unfairly increase comparisons in respect to length. 
The whole shape and organization of these little creatures show that they live in burrows. The proboscis-like nose-cartilaginous, tongh, and flexible-is fit for probing without injury into all sorts of crannies, and for forcing a way through leaves, tangled grass, and loose soil. The feet, nevertheless, thongh cornpact and strong, are not modified into such a

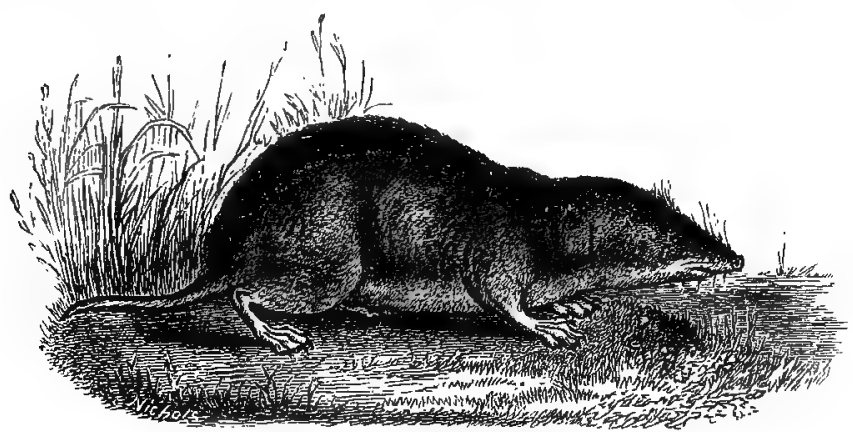

BLARINA-THE SHORT-TAILED SHREW.

combination of pick and shovel as the moles carry, but are mouse-like. The shrew's theory of life is based upon great humility, and it is only by accident that one is ever" seen alive; "restricted to a little world of their own, best suited to their habits and enjoyment, they almost present a barrier to the prying curiosity of man."

Yet they frequent all sorts of country, and readily adapt themselves to widely varying conditions, since their food is universwlly distributed; and, having always an underground refuge from extremes of heat or cold, they have acquired an independence of temperature belonging to few other wild manmals. Possibly this adaptability has counted in preserving the stability of type, which has come down with little change since its first introduction in the Miocene Age. Though common in the rice and cotton fields of the far Sonth, they occur upon our highest monntains, and reach far towards the North-pole. One or two American species are semiaquatic in their habits, but less so than are some of the Old World soricidæ.

Forests and prairies alike are haunted by the shrews, which do not avoid civilized districts, carrying on their secret service regardless of man's pretensions to royalty, and doing so all the more easily because they work at night. In the moist woods of the South and West you can hardly turn over a $\log$ or old fence-rail which shall not exhibit underneath it a inain passage-way and many side-tracks traversed by these small 
pioneers in search of their food, such dark places serving them as a sort of market. When they leave the shelter of $\operatorname{logs}$ and bowlders, they very rarely step out into daylight-howerer often they may go abroad upon the surface during their nocturnal rambles-but move under cover of the leaves and bending herbage, pressing them aside, or, if the earth be loose, descending and tunnelling through it for long distances, until innumerable slender galleries are formed. These galleries open to the surfice at frequent intervals, and in certain favored spots the loam and matted passage will be found to be permeated by a perfect labyrinth of them. They are not dug, but the mould is pushed aside, the pointed snout and nimble toes of the miner making an entrance into which the powerful little shoulders push along with surprising speed.

Through this kind of life the eyes of the shrews have become reduced to mere black dots, less than those of the bat, hidden in the, soft, thick, water-proof fur, and they are of small or no use as organs of vision; the external ear, too, has been worn and flattened in the course of generations of rubbing until it has almost disappeared, what there is left of the anricle being directed backward, since danger from the rear is most to be apprehended in the tunnels, and the delicate sense of touch in the unusually long whiskers and facile snout guards well in front. The superior sensitiveness to touch and sound of animals living underground is well known, and is a natural consequence of loss of the opportunity (finally resulting in loss of power) of sight; the mole is an extreme example of this, and it is the shrew's strongest safeguard. Hearing and feeling the jar of danger, it hides and keeps silent. One careful naturalist* relates how a shrew that he held in his hand wonld start with a quick spasm of fear at every discharge of some guns over a mile away, although the sound was so muffled as scarcely to be andible to the human ear. A slight agitation of the air in its vicinity is enongh to alarm it.

Probably this animal trusts chiefly to touch in choosing and capturing its food. This consists of slugs, enrthworms, and all sorts of insects, with their larvæ; young mice, frogs, snails; eggs, and fledglings of gronnd-bnilding birds; grain and seeds. Carrion, also, is an important resource to it (traps may be baited with beef); and Grodman says that he has found shrews rooting in the barn-yard ordure like little pigs. It is extremely exper' in the water, darting over the surface and diving to the bottom with the greatest agility; therefore, many small aquatic animals fall victims to the lowland species, especially of Neosorex.

* Henry Gillman, American Naturalist, vol. x., p. 430. 
For the pursuit of this food the dental apparatus is well designed. The head is long and narrow, but the jaws large and powerful. There are twenty-eight to thirty-two teeth (varying in different species), which are strong, and colored at the points; the forward ones are recurred, and armed with cutting edges; and no worm is so slippery, no beetle so well armed, that the shrew cannot seize, and hold, and crush it.

The storehouse of the shrew may be placed in the iuterior of a heap of stones, beneath a great log or in a decayed stump; but it is generally a burrow, made a foot or so underground. If the owner is of aquatic lıabits it will
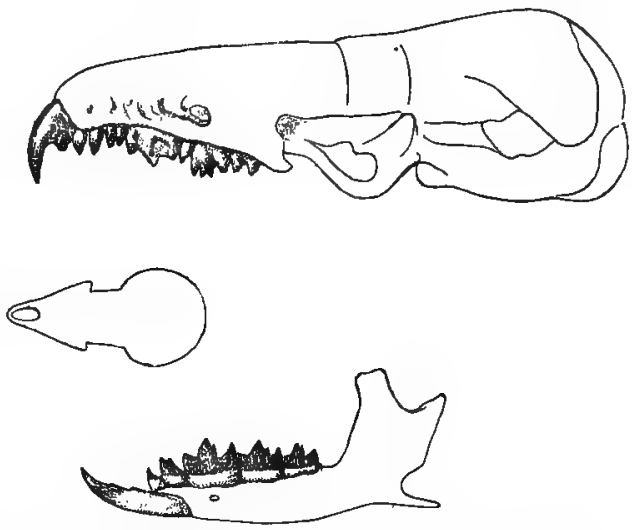

STRLL OF A SHREW (MAGNIFIED), SHOWING CHARACTER OF THE TEETH.

$u$, upper jaw and cranium; $b$, lower jaw ; $c$, mder side of skull, untural size.

have an entrance in the bank of a stream below the usual water-level; bnt among upland shrews, like Blanina, it is reached by the ramifying tunnels. In and adjacent to these winter-quarters, larders, chiefly of seeds, are provided against a snowy day. A surplus of insects may be treasured also. Audubon and Bachman inention that in one of the galleries of the Carolina shrew they found "a small cavity containing a hoard of coleopterons insects... fully the size of the animal itself; some of them were nearly consumed, and the rest mutilated, although living." It is hard to believe the wise little miners did not know what they were about when they left their meat-stores "on the hoof," as it were, instead of killing the insects, and ruming the risk of their almost certain decay.

Even in the coldest weather of the arctic winter this feeblest of the unammals seems never to become torpid.

On fine days he climbs up the little chimneys made about the swaying stems of a sapling or plant-stalk, and seeks wild grains above the snow, leaving an embroidery of tiny tracks. As for the frost, he is able to generate so much heat in his compact and warmly clothed little frame that temperature, ranging even for long periods below zero, does not seem to trouble him at all. Doubtless, like the half hibernating mice, he makes 
runways under the snow, and picks up softened seeds and dormant insects almost as conveniently as in midsummer.

In these winter burrows, which seem to be placed deeper underground in northern than in milder latitudes, a ball-like nest is constructed of Jeaves, grass-blades, and fibrous roots, in which, as spring approaches, four to six young are born, naked and blind. The late Dr. G. Lincecum had several families of shrews in captivity, and learned that the young remained blind until they were half-grown. The father assisted in their cale, bringing home grasshoppers and crickets to the nursing mother" and all the actions of the married pair indicated affection and caressing kindness. The end of this family of pets was distressing. The male escaped, whereupon another pair of captive shrews, making their way into the box where the unguarded family was domiciled, killed and ate not only the little ones, but the widowed mother also.

This incident was quite in keeping with the ferocity of the shrew, character. Like the kinglet and hummingbird, who, though pygmies among their kind, begin and end a fight with an impetnous fury no eagle could exceed, this diminutive quadruped feels that he has courage as big as a lion's. It is rare that two strangers meet without a battle. Caged specimens exhibit the greatest pngnacity. A tonch irritates them, and they will leap at a stick in comical lage, snapping and crying out angrily. Robert Kennicott put into a cage with a short-tailed shrew a meadowmouse (Arvicola) twice its size, which at once attacked its small neighbor; but if the mouse anticipated an easy victory it was mistaken. The little knight of the burrow stood straight up and fought fiercely; and if it did not pursue its adrersary when the latter moved off, neither did it ever retreat, but the instant the mouse came close again, sprang at him, guided, apparently, wholly by liearing and touch. This courage will explain how the small creature can attack and conquer frogs and other animals far larger than itself, as, according to Enropean writers, it is well known to do.

The activity of the shrew is marked. When one is surprised under a $\log$, or turned up by the plongh, it gets ont of sight with astonishing celerity. In this headlong rush the long and extremely sensitive whiskers do the work of the deficient sight, so that when at full speed it will turn aside just before reaching an object against which it seemed just about to strike, and which certainly had not been seen.

A shrew dislikes to cross an open space, or go out of shelter and shadow. This action is prompted by the timidity which, paradoxically, seems quite as phenomenally developed in the shrew as its courage. A gentle- 
man in Michigan caught one very tenderly and folded it in his handkerchief; it died before he got home. Verplanck Colvin, of the Adirondack survey, took one in midwinter on the summit of Mount Edwards, and saw it expire in his hands, although hardy enough to endure the rigors of that weather. I once found one in my mess-kit while on a camping trip in the Catskills; placed in a box without handling, it was dead in the morning. In each case, I have no doubt, the shrews were friglitened to death. It is extremely difficult to keep them alive in captivity.

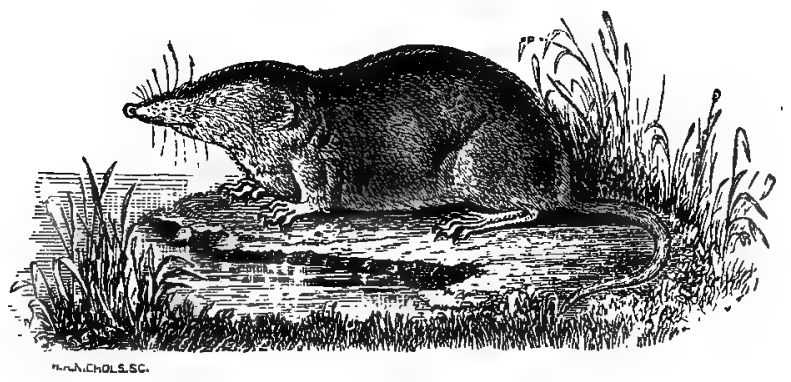

NEOSOREX-THE LONG-TAILED BHREW.

Their enemies are legion, but they have the satisfaction in many cases-if they appreciate it-of knowing that their capture is of no benefit to the enemy. Weasels, skunks, foxes, cats, dogs, and various serpents, besides hawks, shrikes, flesh-eating ducks (like the merganser), and especially the owls, all pursue the shrew for food; but most of them refuse to eat it after it has been struck down, for it carries in a gland on each side a musky exudation, which gives forth an odor and taste so disagreeable that most animals turn away in disgust. This accounts for part, no doubt, of the many dead shrews seen.lying in the woods and fields, by those whose eyes are intent upon noticing matters so small. The fright $I$ have spoken of may account for another share of these cases; and in extremely dry seasons many shrews no doubt starve to deatl, because the earthworms and other terrestrial insects have descended into the subsoil after moisture, or fled farther than the shrew can follow them.

The utility of the scent in these glands (which is stronger in the males than in the females, and more copious at certain seasons than at others) is believed to be as. a guide and attraction between the sexes in their underground wooings, where some other sense must be appealed to than that of sight-or common-sense! But the good purpose it might serve Sorex if, when hard pressed, he conld emit enough of it to disgust 
his pursuer into giving up the chase, is denied him; for by the time puss finds out that her prey is not a toothsome, grain-fattened mouse, the fatal stroke has been dealt.

A similar mistake causes the death of many an innocent shrew at the hands of the farmer, who shonld be zealous to preserve them. Their insatiable voracity is all for his benefit, since it is directed chiefly towards the grubs and beetles, borers, weevils, and other pests of orchard and farm. This pursuit of insects lurking at the roots of his cherished plants goes on ceaselessly and vigilantly all the year round, and there is no one of the list of animals that should be more carefully protected than the shrew, unless it may be his consin the mole.

I have not attempted in this article to go beyond the biography of our own American shrews. Those of Europe and Asia are better known, and would furnish a longer essay. The name "shrew" comes to us from the Anglo-Saxon screáwa-"'a biter." The other epithet-word shrew, applied to scolding humanity, has nothing to do witl this etymologically; but when we think of the sharp face, the purblind eye, the poking disposition, and the rasping, high-pitched voice of the diminutive quadruped, not to speak of the hot temper and needle-teeth, a parallel is certainly suggested.

A ridiculous fable has attached to this little animal in the north of Europe from time immemorial, that it maliciously bites and poisons cattle, whence its name of "venomous mouse" in several languages. The name by which the animal is known among the French peasantry is musaraigne. In this it is easy to see the derivation from the Latin mus araneus; and the explanation is, that the bite of the shrew was formerly considered as poisonous as that of the spider was supposed to be.

I had hoped this had not been imported; but I find in Dr. E. Emmons's Report upon the Quadrupeds of Massachusetts, published in 1840, that in that State the farmers had, at that time at least, so strong a prejudice against these animals that they killed them at every opportunity. "If a shrew," they told Dr. Emmons, "should run over the leg of a cow or horse while reposing in the grass, it would cause lameness." 


\section{IV.}

\section{BIRDS OF THE BROOKSIDE.}

THE pleasantest of all my walks leads me along the banks of a rural stream, where animals of the land, the air, and the water make each other's acquaintance.

The brook comes down from the hills, meander's through a meadow fringed with trees, darts under the rude bridge where the road crosses, and goes gurgling on through depth and shallow, here lost among the reeds of a marsh, there running the gantlet of the old mill-wheel, until the cover of deep woods is reached, and it can afford to saunter slowly under the quiet shade of the oaks and sycamores.

I am impelled to seek its banks by the same constant instinct that led Thoreau always to walk towards the south-west. He thought this inscrutable impulse in him was a part of the settled migratory tendency of the race, insisting on individual as well as national progress westward-an orientation of the mind inspiring poetry and myths the world over.

But the avenues of entrance to a new continent have always been by its rivers, so it may be that my impulse towards the brook is equally owing to a prerailing tendency of humanity; yet I only think of the walk in that direction, if it occurs to me to notice the matter at all, as the quickest way of withdrawing into the wilderness.

"The attractiveness of a brook," said Thoreau, "depends much on the character of its bottom. I love just now to see one flowing through soft sand like this, where it wears a deep but irregular channel, now wider and shallower, with distinct ripple marks, now shelving off suddenly to indistinct depths, meandering as well up and down as from side to side, deepest where narrowest, and even gullying undel this bank or that, its bottom lifted up to one side or the other, the current inclining to one side. I stop to look at the circular shadows of the dimples over the yellow sand, and the dark-brown clams on their edges in the sand at the bottom.... A pure brook is a very beautiful object to study minutely. It will bear the closest inspection, even to the fine air-bubbles, like minute 
globules of quicksilver, that lie on its bottom. The minute particles or spangles of golden mica in these sands, when the sun shines on them, remind one of the golden sands we read of. Every-

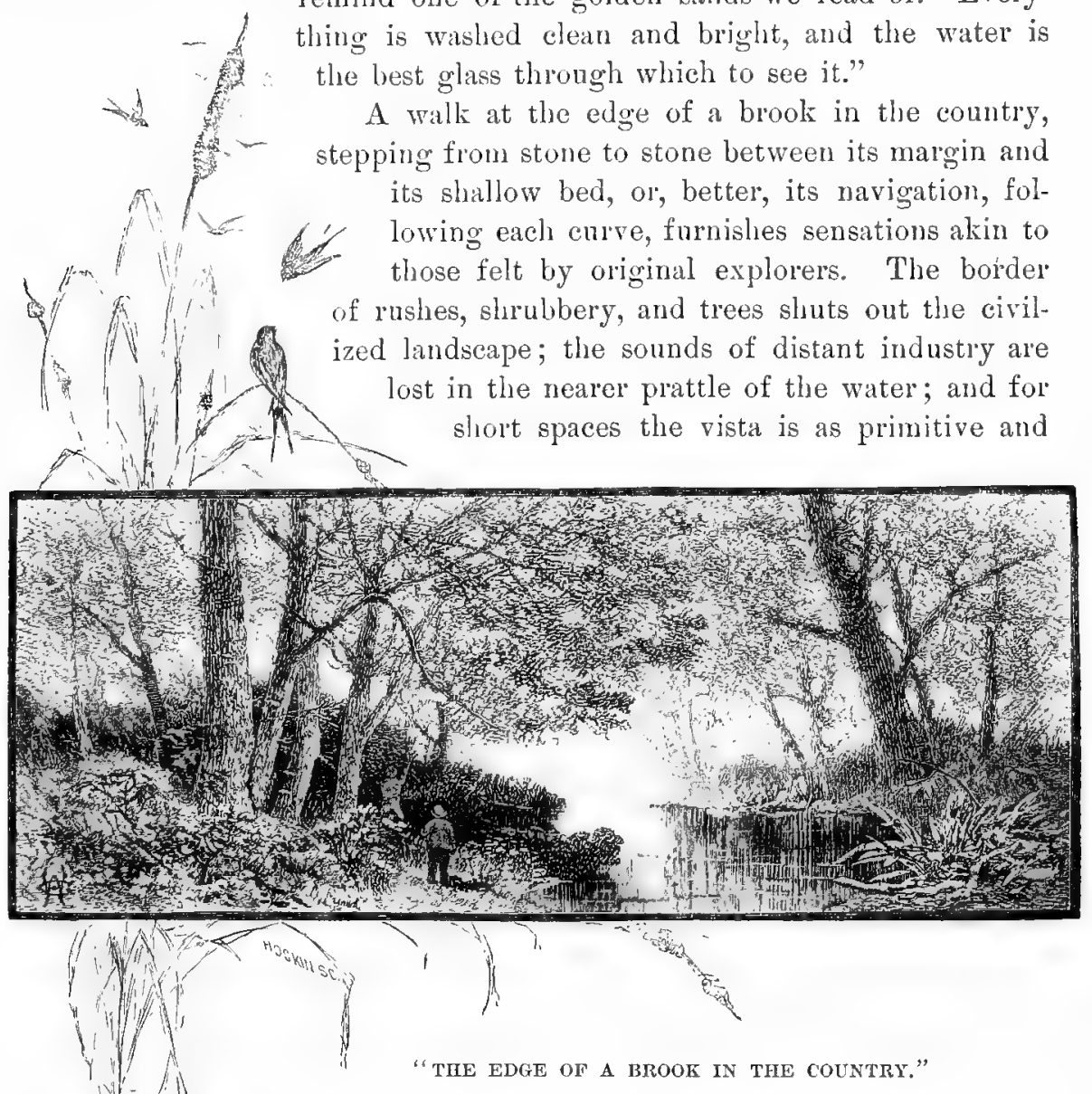

wild as when no keel but that of the red man's canoe had cleft its waters. The hope and exhilaration of discovery revive in rounding every bend, and scenes quite familiar to you from the roadway become novel and fresh when seen from this new point of view.

In the course of a mile along such a stream you may study the whole of geography: on either hand lie continents; the water between may serve for ocean, inland sea, river, or brook, as your fancy dictates; the hills form a terra incognita where are the hidden sonrces 
of this Nile; the mill and bridge are the towns of its world; the meadow and pastnre, the plains and highlands by which it passes; it has islands and peninsulas and isthmuses, capes, promontories, and reefs. The teacher of the district school at the cross-roads can plant a firmer lesson in the restless young minds nnder her charge by an afternoon's stroll along this stream than by a month's study of atlas and definition.

Thither goes the ornithologist on sweet June mornings, when the spring torrent has subsided, and the dog-wood is launching its large petals on the brook. The long-roll of the kingfisher summons him, and he finds a gay company of birds hardly to be met with elsewhere. Two of these are especially characteristic of such a locality, and a walk in early summer will be sure to find them.

Opposite a certain crescentic blnff, where the bank-swallows breed in great numbers, and an occasional kingfisher is to be seen, lies a broad, gravelly beach, which, during spring freshets, is inundated, as is shown by the muddy drift-wood entangled in the lower branches of the willows and alders. Whenever I come here my ears are saluted with a soft little bird-squeal-pee-weet, weet, weet-and a tiny object scnds off on swift, slender feet; or gray wings, trailing downward from its body as though broken, carry it away in a circuitous sweep, just skimming the surface of the water. This can be only

THE SPOTTED SAND-PIPER.

It is an independent little fellow, scuttling in its ridiculous way froin the tropics to the arctic zone and back every year.

Unlike most of its allies, this species is not confined to the sea-shore, nor does it congregate in flocks, but spreads all over the country, following those natural paths-the rivers-until adventurous ones reach even Alaska and Labrador, scale the sides of the Rocky Mountains, and make their nests in the fens far north of Lake Superior. Meanwhile, thousands less energetic, or more economical of time and strength, stay with us in every State, and in the southern portions of the Union succeed in raising two families before warned by comrades returning from the North that winter is at their heels.

It breeds as plentifully in the depths of the Maine forests as on the low, sandy islands, or in the marshes by our sea-coast. The female, about the first week in April, scratches a hollow in the sandy earth by some pond, or sometimes in a corn-field or orchard, lining it with a few pieces of straw or moss, and lays four eggs, which she adjusts, with their snall ends together, in the middle of the nest; these eggs are usually abruptly 
pyriform, sometimes a little lengthened, are clay-color, marked with blotches and spots of unber and sienna brown, thickest at the greater end (where in some specimens they are confluent), and measure about one inch and a third in length by one inch in width.

The nest presents so little to catch the eye that you may look long and not discover that it is close to your feet. The young appear during the first days of June (in the middle parts of the United States), and run about with wonderful speed as soon as they leave the shell, covered with a down of dull gray, marked with a single streak of black down the back, and another behind each ear. Their cry is weak and plaintive.

The parents are greatly distressed by the approach of any person to their nest, and exert themselves by counterfeiting lameness, and by other frantic movements, to lead the intruder away and prevent its exposure. Mr. William Bartram-America's White of Selborne-told Alexander Wilson a pleasant story of how he saw one of these sand-pipers defend her young against the attacks of a ground-squirrel, though it strikes me that it is not the ordinary habit of clipinunks to attempt to devour young birds:

"The scene of action was on the river shore. The parent had thrown herself, with her two young behind her, between them and the land; and at every attempt of the squirrel to seize them by a circuitous sweep, raised both her wings in an almost perpendicular position, assuming the most formidable appearance she was capable of, and rushed forward on the squirrel, who, intimidated by her boldness and manner, instantly retreated; but presently returning, was met, as before, in front and on flank, by the daring and affectionate bird, who, with her wings and whole plumage bristling up, seemed swelled to twice her usual size. The young crowded together behind her, apparently sensible of their perilous situation, moving backward and forward as she advanced or retreated. This interesting scene lasted for at least ten minutes; the strength of the poor parent began evidently to flag, and the attacks of the squirrel became more daring and frequent, when my good friend, like one of those celestial agents who, in Homer's time, so often decided the paln of victory, stepped forward from his retreat, drove the assailant back to his hole, and rescued the innocent from destruction."

This bird is not uncommonly seen also in western Earope, while it winters in Central and South America and the West Indies, departing thither in October.

The spotted sand-piper is small-abont seven and a half inches longand has a straight, slender bill an inch in length, and grooved on each side; the legs and toes are reddish yellow and rather long, the outer. 
toe connected with the middle one by a large membrane. The color of the upper parts is brownish green, with a somewhat metallic or bronzed lustre, marked by many lines, arrow-heads, and spots of brownish black, also lustrous; under parts white, with many circular and oval spots of brownish black, largest on the abdomen; wings greenish brown, crossed by a narrow bar of white; onter feather's of the tail tipped with white and barred with black; line over the eye, white.

Its systematic name is Tringoides macularius, but its common names are many and various-spotted sand-piper, little spotted sand-piper, or sandlark (at Lake Superior, to distinguish it from the "solitary" and perhaps other species of beach-birds), butter-snipe (northern Maryland), fly-up-the-creek (a name also applied to a small heron), all of which refer to its shape and affinities. Derived from its high-pitched, peevish, yet musical ery, are peeweet, peet-weet, and weet-bird, the latter used by old Brickell, who says, "so called from their Weeting or cry before Rain." A nother set of names includes wagtail (Newfoundland), teeter-sripe, teetertail, tip-up, and the like, all describing an action very characteristic of the bird, which, whenever it alights, or pauses in its running, begins at once to mince and teeter upon its legs, lifting and dropping its tail, and rising and sinking on elastic, half-bending toes, as though it were perpetually courtesying, and hoped by an excessive show of good-manners to win your notice, and so get a chance to make some humble petition. This teetering, courtesying, balancing action, recalling Dryden's picture of

"The mincing lady-prioress and the broad-speaking wife of Bath,"

is quite different from the flirting nervousness of the other bird we have made this walk especially to seek.

Following the windings of the growing stream down past the meadows into the woods, where it prowls about the bare roots of old trees, and plunges over a rocky bottom between banks covered to the water's edge with thickets and fern-brakes, we are pretty sure to find one or two little birds that rarely leave such sequestered spots. These are the two cousins of the oven-bird-

THE WATER-THRUSHES, OR WAGTAILS.

Very pleasant little people to know are both of them, although it is not at all easy to make their acquaintance, since they are sliy of being watched, and secrete themselves in the most out-of-the-way places, but always in the close vicinity of the water. The small-billed or New-York wagtail is not uncommon in the northern part of the United States through 
the summer, while it slowly moves in the winter to the Gulf-coast and the West Indies. The large-billed or Louisiana wagtail, on the contrary, is best known at the South, where, in summer, it extends northward to southern Illinois in the west, and to Connecticut in the east.

Each finds its food in the insects and their young that have their haunts among the wet leaves and rank weeds flourishing along riverbanks, and in those aquatic species that eling to stones in the bottom of the stream. On land they have a graceful, gliding walk, not hopping as do most woodland birds. Both are very fine singers-the finest of all the warblers. The small-billed does not seem to have its full share of credit as a vocalist, on account of its modesty, and the fact that its songs are all of love to its mate, seeming never to be wasted on any other occasion than wooing, although then often continued into a moonlit serenade. An enthusiastic writer describes this song as beginning with a startling outburst of melody, clear and ringing, as if surprised by a sudden joy, after which it keeps falling until you can hardly hear it: the tones are strong yet very sweet. But, if you want to see the little minstrel, you must go carefully in a boat to near the place where he secretes himself with his mate.

The large-billed is more prodigal of his music and not quite so cautious about listeners. In the picturesque little "runs"-they wonld be called "trout-brooks" in New England-that find their way down the tangled ravines between the lofty hills of West Virginia, I used often to come upon them, and by ordinary caution conld easily watch them at work or play, or when singing. They seemed to choose to loiter about the pebbly shallows just above the cataract, where they could jump from stone to stone, or run along the drifted logs, rather than to retreat to the dark brakes beloved of the small-billed wagtail. They were never still a minute. Even when standing they seemed to rest unsteadily on their legs, as if their thin, transparent tarsi were too weak to hold them, and were incessantly jerlsing and "wagging" their tails, not depressing them as the sand-pipers do, but flirting them in a restless way.

The large-billed's song is uttered while the bird stands by some log or stone-for it rarely alights upon a brancll-and is full of fire and bright melody, yet it is hardly so accomplished a musical performance as that of his brother. If he gets the idea that he is wanted to grace your cabinet, he vents his indignation in a little chick, like the noise made "by striking two pebbles together," and is off to some secure retreat in a twinkling. "Come upon him suddenly, however, as he is moving nimbly along the margin of some great pool or rippling eddy, and at times he will seem to 
pay little regrard to yur presence, and you may have a fine chance to ol,. serve his motions and sand-piper-like ways, as he wades knee-deep into the water, or splashes throngh it in hot pursuit of some aquatic insect."

Thus pleasantly writes William Brewster, with whom it was ny privilenge to climb those ronged West Virginian hills, and threal thuse charming valleys in search of feathered friends.

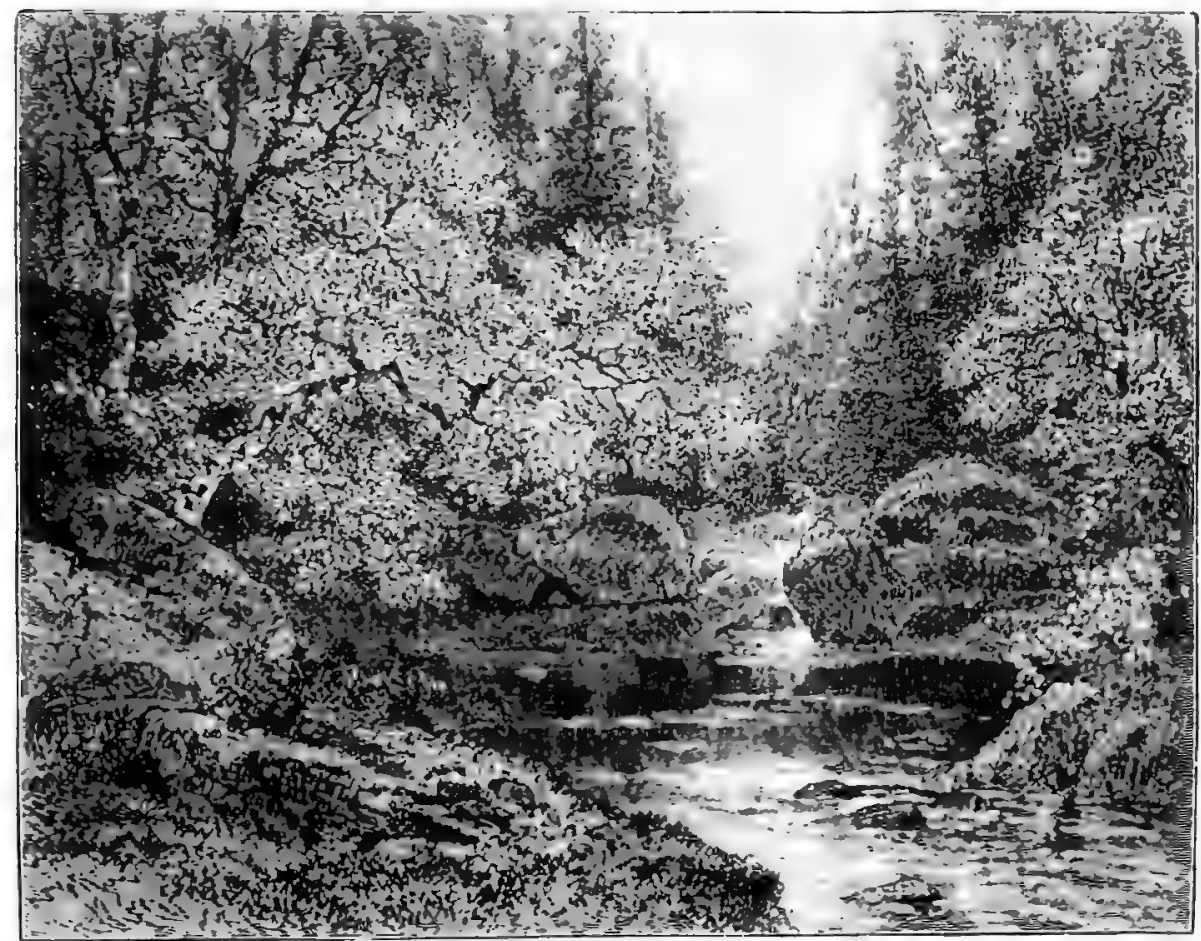

"PEBBLY SHALLOWS JUST ABOVE THE CATARACT,"

All three members of this genus are aptly called oven-birds, becanse of the covered, oven-like nests which they build upon the gronnd. That of the common golden-crowned wagtail is well known to all of us. The northern home of the small-billed is very similar, except that it usually builds beneath a pile of drift or some such object, and so saves itself the tronble of putting a roof over its nest. In the dense cedar-swamps of Maine an rexcatvation is often marle under a decaying loug, and a wam bed of firmly woven mosses and soft tilorous materials is turoked into it. Conld one imagine a snugger resting-place for the red-spotted eggs?

Althongh the Jonisiana wagtails were so common in West Virginil. 
we never found one of their nests; but it was my good-luck to discover its home near Norwich, Connecticnt, where it is very rare, and very much farther north-east than it had ever before been known to breed.*

I was walking up the bed of the Yantic River-much such a stream as appears in the illustration on page 45 -one day in the latter part of June, stepping from stone to stone, and searching the overhanging branches for nests, when a little bird I did not at once recognize darted from under the roots of a beech-tree growing on the sheer edge of the steep bank, and flew straight away, nttering alarmed chirrups. Feeling interested, I concealed myself near by and patiently waited, confident that the strange bird would return. In twenty minntes I was rewarded by its reappearance, and then I saw, with delight, that it was a female largebilled wagtail, and that she had her home under the roots of the beech; but she seemed to have forgotten all about the disturbance, and to be in no haste whatever to resume her sitting. By these signs I concluded that her eggs were fresh, for when she is driven off during the latter days of incubation she rolls and tnmbles about, uttering piteons cries to attract your pursuit. When at length she disclosed its position, I found the nest sunk behind a cushion of moss, and into the rotten wood among the roots, in such a manner that it was covered over completely.

It was rather loosely and carelessly constructed of fine grass and some dead, fibrous moss; but, beneath and about the outside, particularly in front, many dead leaves were put as a sort of breastwork, the more thoroughly to conceal the sitting bird. It was a typical nest, except that often it is more conspicuously placed. The four eggs were of a beautiful rosy tint (becoming pure white after being blown), and were profusely spotted all over with dots, specks, and obscure zigzaggings, of two tints of reddish brown and faint lilac, the spots most crowded at the large end.

In order to distinguish these two species apart, and from the goldencrown, a somewhat minute description of each will be necessary:

The small-billed wagtail (Siurus noevius) is six and one-fifth inches in length, with the bill abont as long as the sknll. The plumage above is olive brown, witl a shade of green; beneath, sulphur yellow, brightest on the abdomen. There is a brownish yellow line over the eye, a dusky line from the bill through it, and the throat and chin are finely spotted. All the remaining under parts, except the abdomen and sides of the body, are thickly streaked with olivaceous brown, almost black on the breast.

* See American Naturalist, vol. viii., p. 238, and Bulletin of the Nuttall Ornithological $C i u b$, vol. iii., p. 133 ; vol. v., p. 116. 
The large-billed wagtail (Siurus motacilla) is slightly larger than the other, and its bill is longer than the skull. The npper parts are olive brown, with a greenish shade; under parts white, with a very faint tinge of pale buff behind. There is a conspicuons white line over the eye, a brown one thongh widening behind, and a dusky line backward from the mouth along the side of the throat; the fore part of the breast and sides of the body are covered with brownish arrow-shaped streaks, bat the chin, throat, belly, and vent are unspotted. This is a northern bird.

The golden-crowned wagtail (Siurus auricapillus) is six inches long, and colored as follows: Above, uniform olive green, with a tinge of yellow; crown with two narrow streaks of black from the bill, enclosing a median and much broader one of brownish orange; beneatl, white; the breast, sides of the body, and a maxillary line streaked with black. The female, and young of the year, are not appreciably different.

The latter species, like others of the genus, is noted for its vocal powers and for its nest. In regard to the first, John Burronghs has left nothing for me to say, as you will agree after reading pages 64 and 65 of "Wake Robin;" but of the home of the golden-crown I must write a brief description.

Rather an early arrival in the middle and northern States, wintering rarely this side of Mexico and the Antilles, it quickly proceeds to establish its well-guarded dwelling in the edge of the woods, less often in a cleared space, and then only when the shelter of bushes is close by; and it is noticeable that the neighborhood of water is not important, as is the ease with its congeners. Scraping aside the dead leaves, until a foundation of solid earth is secured, the skilful bird entwines linear leaves, grasses, shreds of bark, and bits of moss or blossoms, into a circular bec' both dry and warm. Then, from materials close at hand, and hence not easily discernible through any difference between them and their surroundings, she heaps up a parapet, and drags upon the top old dead leaves, long dry weeds, and stems of grasses, pieces of light bark that squirrels or woodpeckers have thrown down, and even twigs, until she has made a complete domed roof over her snng domicile, with its little unnoticed door in front whence she can peer ont. In this way she constructs a cave-house, where she may sit secure from anything short of an accident.

Varying in its timber with the kind of wood or pasture in which it is placed, the only way to find it is by searching the ground where a nest is suspected, or where it seems likely ore may be, until the bird is startled out of her retreat. Even so, one cannot always be sure of his prize; for 
when thus surprised, the mother runs from her nest with the silence and celerity of a mouse, rarely losing her presence of mind.

These nests are not, however, invariably domed like old-fashioned ovens in miniature. Now and then the shrewd bird so takes advantage of a sheltering rock, or the protection of a projecting root, where no superstructure wonld be necessary to its concealment, that it is saved this trouble and builds no dome; and I think that the roof of a nest, nnsheltered by any rock or root, must be intended as a guard against the eyes of enemies rather than any shield from the weather. The fact that nests built in very thick woods are frequently left uncovered supports this belief. Dr. T. M. Brewer tells pleasantly how his dunghter, then a child four years of age, discovered such a one. It was built in a depression in the ground, and its top was completely covered by the natural growth of smrrounding vines and wild-flowers. Although the little girl and her father were standing with their feet almost upon the nest, the warbler remained sitting quietly until the child stooped to pluck the flowers growing directly over its entrance; then the bird darted out, and fluttered and tumbled about with well-feigned mancuvres to distract attention from her treasures. The clild, in great glee, tried to catch it, but of course failed; while the father, wiser in the ways of birds, stooped to examine the nest and saw that it had no other cover than the wild plants that naturally clustered above it.

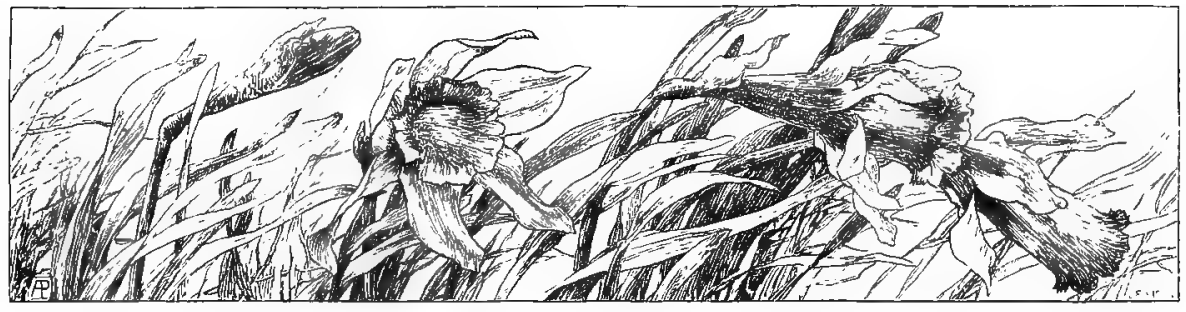




\section{V. \\ WINTER WORK FOR NATURALISTS.}

W HEN winter has come fairly upon ns, ont-door work in most cases must be exchanged by the naturalist for that which may be carried on within doors. There need not, of course, be an entire suspension of the collector's labor. Fungi spring up by the myriad on every side, mosses seem to take on a new vigor, and a few hardy wild-flowers brave the storms, repaying the diligent botanist for his walk. The entomologist may be able to find dormaut larvæ underground, or beneath loose bark, if he take the trouble to search for them; and any one can get a certain number of species of birds and quadrupeds at this time, not.likely to be seen at the opposite season of the year. In a snbsequent chapter I shall sketch the way in which the animal life of the northern part of the country meets and endures frost, snow, and chilling temperature.

$\mathrm{But}$, as a rule, the naturalist looks forward to the winter as a time of rest from such labors, when he may devote himself to the study of the treasures which his summer jaunts have yielded him. The botanist arranges his delicate dried plants in clean papers, labels and classifies them in permanent shape. The oölogist brings out his nests and eggs in the long erenings, sets the former into paper shells or suitable boxes, and arrarges the eggs in his cabinet anew, making room for the novelties. The conchologist lays aside his dnplicates for exchanges, and notes points of interest about lately acquired specimens. Microscopists busy themselves in mounting new slides and careful examination of old ones, while, unmindful of wind and snow ontside, the chemist or electrician is engrossed in experiments with novel contrivances for extracting Nature's secrets. Least of all does he look forward with dread to the confinement of winter who is happy in the possession of a thriving aquarium, for here is a little square bit of green and growth, preserving to him the $i d e a$ of summer if nothing more.

But there is a class of persons who, while they certainly feel an inter- 
est in the productions and processes of nature, and are accustomed to use their eyes, have never had the opportunity or the habit of making natural history a practical study. They may not be willing to devote time to, or have learned enough to understand, technical books; or may not be able to buy them, since unfortunately it is rare that books of this kind are both cheap and good. Moreover, while many would be pleased to know the general facts of zoölogy and botany, they do not propose to become special students; just as a man may have a good ear for melody, and take delight in hearing singing or an instrumental performance, without any strong desire to pursue a scientific training in music.

The influence of such persons ought not to be lost to the cause of natural science, nor onght they to be deprived of the charm and benefit of its study; and there is a method by which they may not only add to the knowledge now possessed, but make themselves more ready and intelligent observers during subsequent out-door seasons. The latter would be the more positive gain of the two, for the facalty of observation is an acquired capital which is sure to return a large interest. The method to which I allude is the formation of natural history clubs, which, even when most informally conducted, will serve an excellent purpose in village society.

In many towns scientific associations already exist, but perhaps have been neglected altogether, or else allowed to fall into the hands of a few unprogressive persons, who, by monopolizing them, have destroyed the vitality. Revive these organizations if they are worth it, and guard against nudue profundity in one or two nombers, particularly if they are inclined to be talkative. This kind of a man discourages the younger, timid, and more humble-minded ones, who nevertheless might have very suggestive facts to offer if they were not awed into silence. I have in mind one of the most influential societies of this kind in the United States, whose rule for several years after organization was, that no professional natnralist or elderly man should be admitted. After a time, when all the youngsters had learned confidence in themselves, and by good work had confirmed the respect of their elders, the wise-heads were let in, and were very thankful for the privilege.

\section{"The cups that cheer but not inebriate"}

are a great help to break the ice of such a first meeting, which needs to be freed, once for all, from a feeling of chill dignity. In such a pleasant parlor-chatting, cakes-and-ale way, was the powerfal Biological Society of Washington set on foot in 1881 ; but through a continuance of, 
and the consequent rivalry set on foot by, the dangerous practice of edible entertainment at all the meetings, its predecessor, the Potomac Club, had come to an untimely end.

There are always two or three persons in a village interested in scientifie matters who can tell a good deal, if they choose, about the natural history of the neighborhood. Let these get together, invite such friends as they think likely to come, and spend an evening in talking over the geology and antiquities, and the habits of the birds, beasts, insects, and plants of the vicinity.

After this neighborly beginning is achieved, even though there may be few mutual acquaintances in the room, young naturalists, or would-be naturalists, will find little difficulty in conversing on the topic that has brought them together. The humanizing influence of natural science is great; and becanse of this, no doubt, arises the good feeling which all true naturalists possess when in each other's company. I believe, also, that nothing in the world will preserve youth, in spite of advancing years, like this study and companionship with ever-rejuvenate nature.

Haring decided that your circle will be able to come together regnlarly, it is well to introduce some little formality in order that time shall not be wasted. "As in races," said Bacon, "it is not the large stride or high lift that makes speed; so in bnsiness, the keeping close to the matter, and not taking of it too much at once, procureth despatch."

But this formality need go hardly farther than the choice of a chairman, whose care it shall be to find at least oue member who shall suggest the leading topic for attention that evening, by reading a short paperso far as possible one of original observation, very practical, and expressed in the siuplest phraseology. It is a good thing to let this topic be known to the members somewhat in advance, if possible.

The discussion which follows will be likely to bring out many facts which, trivial in themselves, are of value as necessary links in the chain of information. The chairman shonld also be expected to insist that no speaker be interrupted while he is talking. This, however small and ungracious a matter it may seem, has proved to be an inportant rule in such elubs. But do not attempt the strictness of parliamentary usage. I know of two flourishing societies-yes, three-where all the members get out their pipes as soon as the papers begin to be read.

This suggests a momentary digression. Of course the smokers just alluded to were sitting in the absence of ladies, who do not often belong to the Academies; but in the local clubs I have in mind there is no reason why they should not be present, and active members-every reason 
why they should. They need the recreation quite as much as husbands and brothers; they can contribute facts equally worth hearing. In a western city of some twenty-five thousand people a natural-science society was started by a small circle of ladies and gentlemen, which in less than half a dozen years made itself the intellectual centre of the town, and exerted a constant and most wholesome influence towards the advancement of knowledge, the habit of observation, and the cultivation of accnracy and criticism. To this success the ladies contribnted quite as much as the gentlemen. This society saw the various danger's and temptations arising from the practice of meeting at nember's' houses, and early adopted the better plan of meeting in a room of its own. This can generally be done without expense, as a school-room, a library, or some other semipublic place will be procurable, in most cases, until the society is strong enough to provide its own club-room.

Now comes the question: What topies may, and what may not, be considered by such a club, for a line must be drawn. Well, this depends. There are two great divisions of the sciences-the plysical and the natnral. It is doubtful whether both branches can be entertained very well by a village club, at least on the same evening. In a natural history society the stndy of geology, animal and plant life, and prehistoric remains of human occupation would be admissible, and notling ontside of this. It is well to remember Bishop Wilson's maxim: "Avoid as much as possible a inultiplicity of business."

It is better sometimes, even at the risk of offence, to refuse would-be helpers whose zeal outruns their judgment. A collection of coins, a volume of autographs, curions carvings from China, or bits of tapestry from Flanders, are no doubt interesting things; but these must not be allowed, on the evening deroted, to natural history, to take up the time of the company, who are all in earnest to tell and hear the new facts learned on that topic since the previous meeting, and will look at your coins and your tapestry to-morrow. Keep the club closely to its own work.

“To doubtful matters do not headlong run;

What's well left off, were better not begun."

But how shall that work be furthered? We would suggest that living objects, or at least their preserved remains, be brought to the society's notice in preference merely to talk $\grave{a}$ propos of nothing. The presence of some pieces of rock and a few distinct fossils from the nearest ledge; the skin of some uncominon bird or quadruped of the neighborhood; a box of moths, bntterflies, or beetles, exhibiting the family representation 
in that district; or a-collection of mosses, lichens and fungi, just plucked, will form a subject for conversation, and lead to further inquiries in a way that no paper-reading can do. Do not let the essays take the place of living specimens any more than can be helped.

Another suggestion is to attend, first of all, to the natural history of one's own locality, and next after that to what belongs within the United States. Do not go wandering off to Alaska for an account of the furseals cribbed from Elliott, or down to Ceylon to tell about something which you may read of in Wallace. It is, however, a good plan to exhibit and call attention to new books and serial publications which may not be known or accessible to all the members; and it will be found that no little rivalry will grow up as to who shall be the first to bring forward this sort of information.

Thus a naturalist may employ his winter without losing ground. Most of these suggestions have stood the test of experience and are found to work well. If half a dozen or a dozen really earnest people meet together occasionally between November and April to discuss the natural productions of their neighborhood, resolntely excluding everything else from their attention for the time being, they will surely become so interested that the advent of spring will find them eager to get ont into the woods and fields, where they will see and keep enough material and information to last them throngh the next winter thrice over.

In the very simplicity of the plan proposed lies the secret of its success; introduce much red-tape and machinery, along with many very wise professors, and ten chances to one the club will die of old age in its first season. "Difficulties may surround our path," to quote Dr. Jowett, " but if the difficulties be not in ourselves, they may generally be overcome."
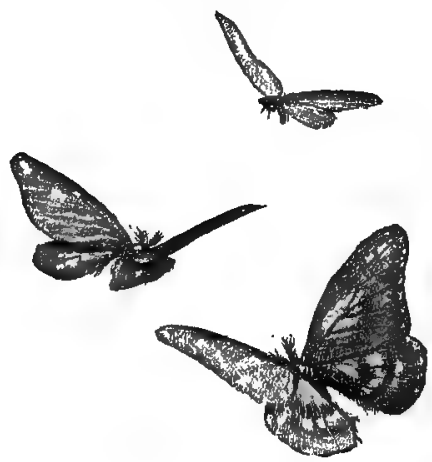


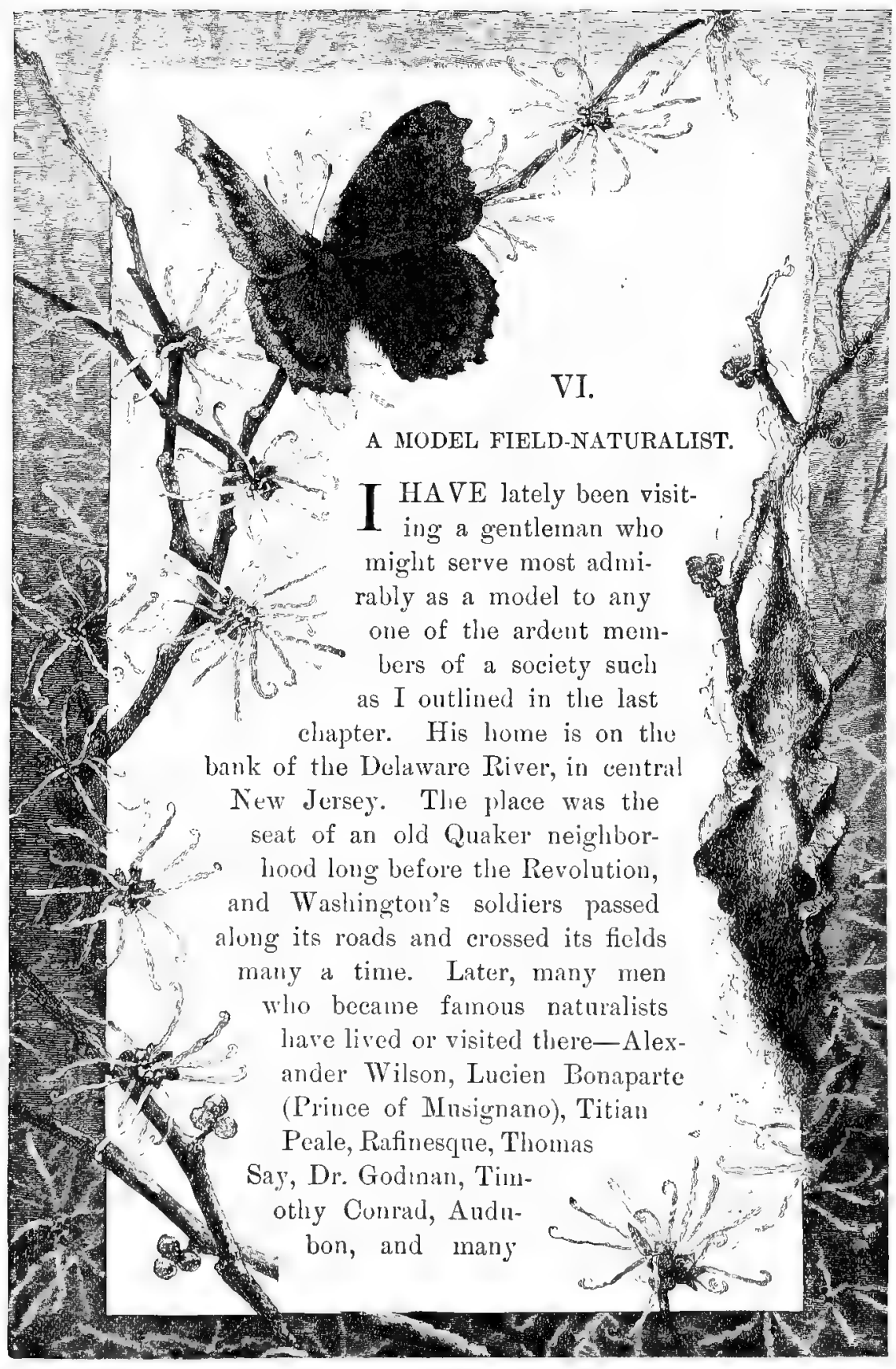


another-so that my friend is only following legitimately in the foot-

- steps and tastes of his ancestors when he welcomes the many men now famous in science to his hospitable farm.

From Trenton down, the Delaware River is bordered by very wide flats, known as "The Meadows." At one place, fully a mile from the river, a long, steep bank rises to the level of the farming-lands behind, and shows the ancient limit of the river freshets. In a beantiful grove on the summit of this bluff stands the picturesque old home of my friend, with its group of barns and sunny gardens about it, and the broad grainfields behind. Thus pleasantly placed for hearing and seeing what goes on out-of-doors, this gentleman has taught himself to be one of the best field-naturalists in the world. By "field-naturalist" I mean one who finds out the appearance and habits of plants and animals as they are when alive and in their own homes, and who does not content himself merely with reading what other's write about them.

It is very delightful to talk with this gentleman, and to see how well he is acquainted with the birds and the four-footed animals of his district, all of which are under his jealons protection. He has half a dozen little "tracts" within a mile of his house, each of which is tenanted by a partly different class of plants and animals, so that there is never any lack of variety in his studies. The truth of this will not seem clear to you at first, perhaps, because you are accustomed to think that, in order to find any great diversity in out-door life, you must search throngh great spaces of conntry. But my friend's farm would show us that a great many little differences are ordinarily overlooked, which, when we come to know them, are seen to be real and important. And this can be proven in one place abont as well as in another.

For instance, it is easy to divide the estate I am speaking of into four districts, so far as natural history is concerned. First, there are the upland fields and house-gardens; second, the steep hill-side, grown dense with trees and tangled shrubbery; next, the broad, treeless, lowland meadows; and lastly, the creek, with its still, shaded waters, marshy nooks, and flowery banks.

Now, while there are many trees, bushes, and weeds that are common to all these four districts, it is also true that each of the districts has a number of plants and animals not to be found in the others. You would not expect to get water-snakes, musk-rats, or any wading birds on the high fields behind the house, nor do the woodchucks, quails, and vespersparrows of the hill-top go down anong the sycamores by the creek. One quickly gets a hint here of the great fact that any species of animal 
or plant may be spread over a whole State, or half the continent, yet, nevertheless, be found only on that kind of ground which is best suited * to it.

One of the very first things a naturalist has to learn, therefore, in respect to an animal whose habits he wishes to study, is what sort of sulroundings it loves, and he will be surprised, particularly in the case of the smaller creatures, to learn how careful animals are in this matter, since upon it, as a rule, depends their food and safety. There are certain snails, for example, which my friend tinds in one corner of his farm and never anjwhere else. A pair of Bewick's wrens have lived in his wagon-house for some years, but they are the only pair in the whole county. It would be of no use for him to look anywhere off his busllgrown hill-side for the worm-eating warbler, the monrning-warbler, or the yellow-breasted chat, though his gardens ap above entice many other birds. Similarly, when the Carolina rail decides to make its home on his land, it does not settle along the creek, but in a marshy part of his meadows. I might mention a large number of equally pertinent exanples, but these will suffice.

For more than twenty years my friend has been diligently studying this single square mile around his house. One would think he knew it pretty well by this time, and he does-better, I believe, than any other square mile is known in the United States. He can tell you, and has written down, a hundred things about our common animals which are real news; yet he thinks that he has only begun, and is tinding out something more every few days.

Here is an instance:

Forty years ago, or more, a small, brightly spotted species of turtle was described as living near Philadelphia, and two miserable specimens were sent to Agassiz. It was called Mühlenberg's turtle, and since then not one has been seen until last summer. My friend was always on the lookout, never failing to pick up or turn over every small turtle he met on the meadows or along the creek, and examine whether: the marks on its under shell were those of the lost species. Finally, one of the ditches in the meadows was drained off to be repaired, and there, within a short distance, were picked up six Mühlenberg turtles!

They could easily have gone out of that ditch into other ditches, and into the creek; but if ever they aid so, they succeeded for twenty years in escaping some pretty sharp eyes that would liave been very glad to see them. Afterwards two more were obtained, and all are preserved in the Museum of Comparative Zuölogy at Cambridge, Massachusetts. 
This little incident has a moral for us in two ways. One is, that often the apparent rarity of an animal comes from the fact that we do not know where to look for it; and the other, that it requires a practised eye to recognize it when at last it connes to light. Many instances of the first named "moral" might be quoted from the history of American birds. There is a sparrow (Centronys bairdi), now common enough in the collections of museums, and whose habits are well known, which for thirty years after its first discovery on the Upper Missonri by Audubon, kept itself out of sight. Sprague's lark, of the same region, affords another similar instance.

Practise youl methods of observation, then, without ceasing. In no other way can you make discoveries, and the cultivation of the habit will be of inestimable advantage to you in many ways.

This is the merest hint of how, without going away from home, by always keeping his eyes open, a man or a boy or a girl can study, to the great advantage and enjoyment not only of himself (or herself), but to the belp of all the rest of us. I should like to tell you how patiently this naturalist friend of mine watches the ways of the wary birds and small game he loves; how those sunfish and shy darters forget that he is looking quietly down through the still water, and go on with their daily life as he wants to witness it; how he drifts silently at midnight, hid in his boat, close to the timid heron, and sees him strike at his prey; or how, concealed in the topmost branches of a leafy tree, he overlooks the water-birds drilling their little ones, and smiles. at the play of a pair of rare otters, whose noses would not be in sight an instant did they suppose any one was looking at them.

But I cannot recount all his vigils and ingenious experiments, or the entertaining facts they bring to our knowledge, since my object now is only to give a suggestion of how much one man may do and learn on a single farm in the most thickly settled part of the United States. "What you seek in vain for half your life," said Thoreau, "one day you come full upon all the family at dinner."

And yet, as Emerson well remarked, none knew better than Thorean that it is not the fact that imports, but the impression or effect of the fact on your mind. "Let ine suggest a theme for you," Thorean writes to a friend-" to state to yourself precisely and completely what that walk over the mountains amounted to for you." 


\section{VII.}

\section{NATURE IN WINTER-QUARTERS.}

W HILE we are upon the subject of winter studies, some account of how the animal world meets the cold weather will be appropriate. It will be land animals chiefly that will interest ns, since, in the sea, winter or summer makes small difference a few feet below the snrface, and the creatures living there are not much affected by the changing of the seasons. The same thing seems to be true, to a great extent, of the fresh-water sponges and the infusoria that crowd our ponds and ditches. These microscopic beings, standing on the borderland between plants and animals, have wonderful hardihood, reviving after becoming as dry as sand in a lot oven, and proving equally defiant of snow and ice. You may collect them as abundantly in February as in May. Their companions, the minute, transparent entomostracans-lowly relatives of the crabs-stand the cold equally well, though some species never live longer than from their birth in spring until after they have laid their eggs in the fall.

As for the worms-I mean the true worms-they survive the winter buried suugly in the mnd; while the water-spiders, that come next to them in the scale, keep comfortable by sleeping in a little globule of air, and clinging to a weed-stalk or a sunken stone. This globule of air they are able to carry down beneath the water with them, because their bodies are clothed with long hairs. To all this small water-life, indeed, the winter puts little or no check. When you rise to a somewhat more highly olganized and more sensitive class of creatures, the insects-most of which live out of the water, at least after they are fully grown-you find that winter is dreaded and guarded against.

The best that many insects can do, to be sure, is to die at the approach of cold weather; but in this case eggs have been laid where it is hoped they may be safe, or else the young in some stage, ceasing to grow, have retired to sleep away the long, dull days until the April suin shall wake them up. The bark of all the trees in the forest and orchard harbor 


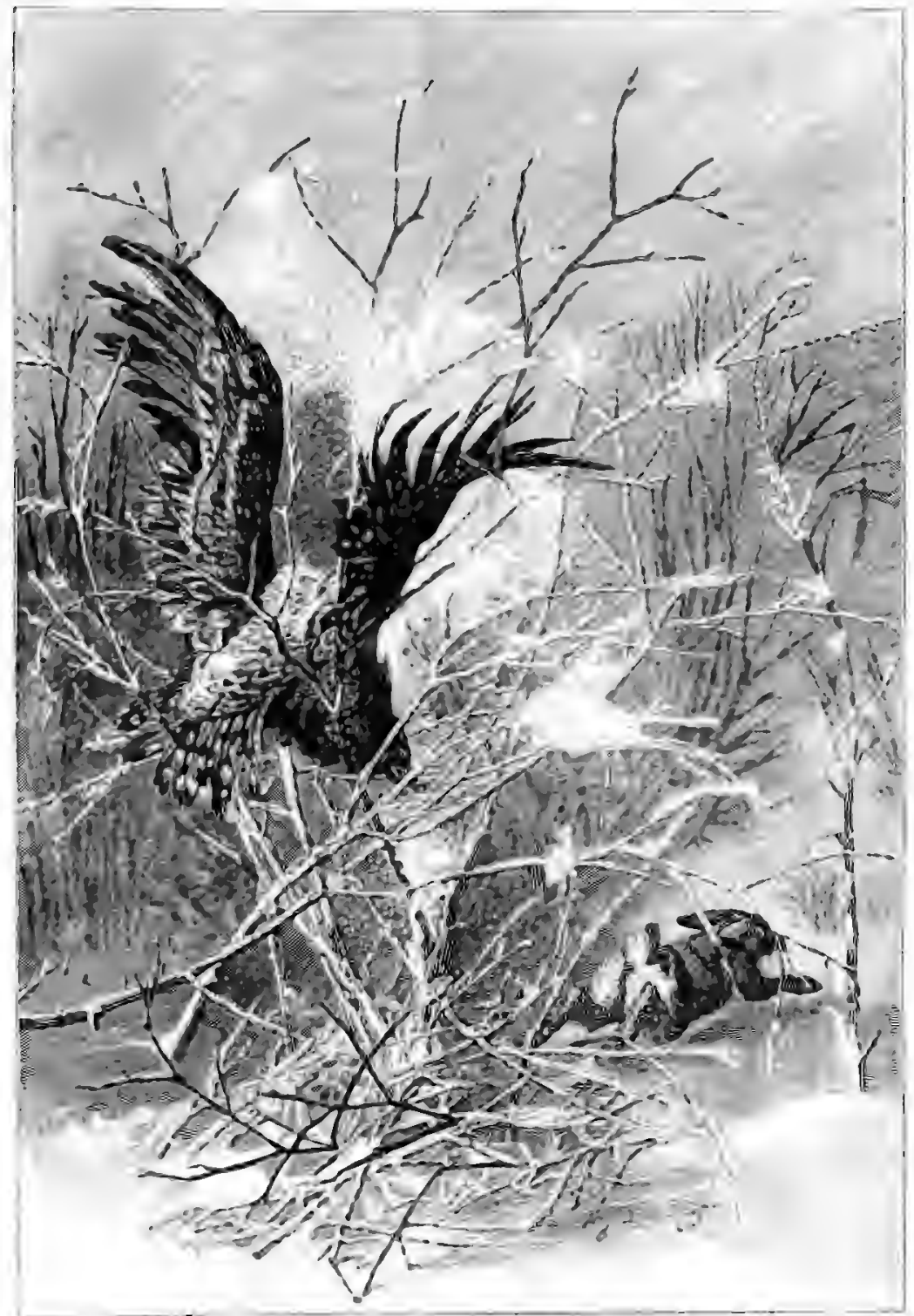

TIIE ATIUGGLE FOR EXISTENCE IN WINTER. 

multitudes of such young insects; they hide under the leaves, nestle in rotten wood, burrow in loose earth, creep into snug crannies, sink beneath the water, and, in almost every situation you can think of, as eggs or grubs or chrysalids, are dead to all the chilling blasts, until the fir'st warm breath of real spring re-vivifies their motionless forms.

Yet great numbers of adnlt iusects remain alive through the winter, and some of them require very little encouragement to venture out of their beds on thawing days. The great order of beetles is an example of this, and thousands of small spiders may often be seen running over the snow during" a "warm spell" in midwinter. Nor ought the appearance of butterflies at the holidays to excite otir wonder. Several species of the genus Vanessa, especially $V$. antiopa and $V$.progne, spend the season nnder logs, ledges of rock, ete., and the appearance of a warm sunny day will bring them into activity, when they may be seen flitting about, often in large numbers. The delicacy of these creatures does not seem to prevent their standing severe cold. Aretic species exist, and butterflies and moths may be found upon the freezing, storny peaks of the highest mountain-ranges. A specimen of Philampelus labruscce, a large green moth belonging to the Sphingidoe, common in South America and the Antilles, and rarely taken in the United States, was found alive, fresh and beautiful, in Fairbury, Illinois, on Jannary 8, 1874, after a severely cold period, wlich was followed by fearful winds from the soutli, causing heavy rains and thunder-storms. The sontherly winds, of coprse, explained the presence of the tropical insect, but its hardihood was noticeable.

A large amount of information on this general subject is to be found in Mr. S. H. Scudder's valuable book, "Buttertlies," chapter viii., headed Seasonal Changes and Histories.

When, therefore, frosts and heavy storms begin, such insects as do not propose to die that year hide away in warm nooks, crawl behind the loose bark of trees, or poke their way underneath old logs in the woods, where they find hosts of minute companions. When it gets too cold for them to wriggle, they go to sleep and remain so until warnth returns, no matter how long the frosts may hold fast. This is called becoming dormant or torpid, and another prominent instance of it among lowly animals is in the case of the snails.

As cold weather approaches, the snail crawls under a half-buried stick or stone, and attaching himself to it, aperture upward, by forcing out a little glue at the edge of the shell, throws a curtain of mucus across the aperture. This quickly hardens into a kind of drum-head, and, later, a second, or even a third, is formed inside of it. Through these curtains 
no air can pass out from or into the shell, and its occupant settles down to undisturbed repose. The circulation of his blood seems quite to cease, and it cannot be detected that he breathes-at least a chemical test will show that the air within the shell is as pure as that outside. It is wonderful what extremes of temperature these little creatures are able to bear. The fiercest heat of summer does not harm them, nor excessive cold. Professor Verrill, of Yale College, told me the other day that he once

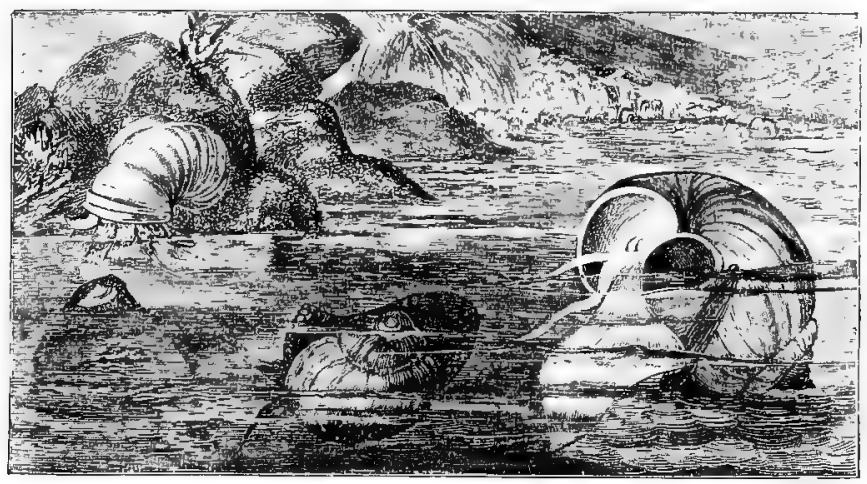

THICK-SHELLED PALUDIN\&.

placed eighteen snails in a box containing sand two or three inches in depth, and left it exposed in his garden during the winter. The mereury went to twenty degrees below zoro, yet in the spring half of them were alive, though they must have been frozen solid inany tines.

The same is true of the bubble of air with which the water-spider surrounds himself in his torpid rest under the ice of the pond. If you should break in the drum-head of the snail he would freeze to death; and if you draw the air out of the bubble around the spider, he will drown before he awakes. It is necessary, then, to the safety of both, though neither seems to breathe it; perhaps it serves as a kind of blanket, within which snails and other little creatures are able to pass without exhanstion the long, cold months, during which, if active, they would be mable to set any proper food, and therefore would starve to death.

Some snails, however, seem to hibernate very little. Thus the small, glassy mollusk, Vitrina, has often been seen crawling abont when there was snow on the gronnd. It is perhaps in consequence of this hardihood that it extends its wanderings into polar regions, and can be collected upon very high mountain-tops. I have seen it lively in the high sierras of Colorado, when the grass was stiff and white with frost, all the brooks 
silent under a sheet of new ice, and not another mollusk of any sort to be found moving.

Water mollusks, such as the river-mussels, the coil-shells, and the thick-shelled Paludince, do not need to hibernate, because they are protected by the water always flowing over them, and need only sink in the und or go to a deeper part of the stream.

After the invertebrates come in regular order the fishes, which are affected only slightly by wintry rigors. The waters frequented by many of the fishes of our inland streams are often only shallow rills, that go nearly dry in the fall. I do not think, however, that the trout, shiner's, sunfish, minnows, darters, and the like, let themselves often get caught by the ice at the head-waters of these small streans, for there the ice would freeze fast to the bottom and might remain so for several months. Nevertheless they may do so, and would no doubt survive it, since some of them are accustomed to bury themselves deep in the sand and mud at all seasons, and so can get along on a small and impure supply of water; another of their habits is to congregate about springs bubbling up in the bottom of the stream. Moreover, experiments show that fishes may be frozen into a block of ice, and still come out all right when their prison thaws away from them. Thus it happens that small fishes, overtaken by sudden hard frosts, could be frozen into the solid ice or more solid sand of a brook-head, and remain there as stiff and dead as sticks from December to March, yet prove alive and well enough when the April sun honeycombs the ice and wakes them into new life. This is a stoppage of vitality-a temporary death-somewhat different from torpidity; moreover, there seems no limit to the time a fish night remain thus congealed and still recover, since no bodily waste goes on during his confinement.

The rule among fishes, however, is to run away from the shallows as the chill of approaching winter begins to find them ont, and to seek waters deep enough to insure their not being frozen to the bottom. Underneath the ice the water is none too cold for their comfort, the bottom is free for them.to forage upon, plants, becoming greener and greener as spring advances, give the vegetable-feeding species dainty meals of everfreshening sprouts, and varions enemies, such as birds and boys, are shut off from harming them. The amount of food consumed, however, is very small. Thus, under the solid and storm-swept plain which covers the lake and broad river, there is lived a peaceful, happy, industrious life in the greenish twilight of undisturbed depths. 
As for the fishes of salt-water, they go to unknown abysses and distances, returning when spring opens to ascend the rivers and revisit their old haunts. It may be said of fishes generally, therefore, that they spend their winters in deep and comparatively warm water, out of the reach of the ice and cold which chains the brooks and shallow ponds.

Next to be mentioned is the class of half water, half land animals, called Batrachia, after the Greek name of the frog. The batrachians include those repulsive, lizard-shaped, flabby creatures, haunting western and southern streams, which are called sirens, water-dogs, and mud-puppies; the more graceful salamanders, newts, efts, and tritons; and, as the highest division, the frogs, toads, and tree-peepers, the "tadpoles" of which lose their tails and their lizard-like form when they become of full age.

Few of these animals live in deep, clear water; the great majority haunt muddy streams and marshes, or else spend most of their time on dry land. Their food is obtained either from the water or from insects, and cold weather cuts off the supply in both cases. It is necessary, therefore, as with the snails, that they should be able to survive the winter without eating, and they do so in pretty much the same way as the snails, by creeping into the mud at the bottom or on the margin of streans and ponds, and going into a half-torpid sleep. Some of the salamander-like batrachians can live wholly in the water, being provided with gills like fishes. These, therefore, can retain their activity where the water is deep enough to protect the bottorn from freezing, and, as they live mainly in southern streams, they know little about cold weather; otherwise they seem to hide away among the roots of aquatic herbage. Toads must have air to breathe, and hence could not exist underneath ice, except in a state of torpor, where breathing is suspended; but frogs are capable of skinrespiration, and can live under water indefinitely if food is supplied.

Their hibernation, whether in the mud, as in the case of frogs; in holes in the earth, in cellars, or under old logs, as toads do; or in the rotten wood inside hollow trees, which some of the tree-toads are supposed to choose, is not so strict and lasting as it is with snails and insects. It depends only on the degree of cold, so that it not unfrequently happens that the piping of frogs will be heard here and there in midwinter when the snow has left the ground and the sun thaws out the frost. But a chill. ing wind shuts their voices up again until early spring, when they are the first to respond to the invitation of the new season. There is reason to believe, however, that all the frog-like batrachians do not live over from 
year to year, by hibernating during the wiuter. For instance, the small "peeper," or cricket-frog, which is so noisy early in spring, lays its eggs in April, and soon after the greater number of thern die. The tadpoles pass gradually into the adult or tailless condition, and, in the hannts of the parents, which for four months were nearly or quite tenantless, the offspring appear late in August. These hibernate, to reappear in the following spling, sing for a few weeks, lay their eggs, and die. True frogs, like the wood-frog (Rana sylvatica), an excellent portrait of which is shown in the left-hand figure of the frontispiece, * live for five or six years.

Passing to the turtles and tortoises, we may say of those that live in the sea that they migrate to deep waters, like the fishes; and of those dwelling in fresh waters that they pass the winter asleep under the shoremud as do the frogs, unless they lire far enongh sonth to make hibernation needless. The land tortoises (which, by the way, make most interesting pets) you will find burrowing down into loose dry earth as winter comes on, where they sleep undisturbed until spring. A warm noonday often aronses them, when they will creep languidly out, diag their drowsy forms into some sunny spot, and doze until the evening slıadows remind them that it is best to seek once more the protection of their snug earthen blankets, where perhaps they will remain invisible for another month or two. Usually they dig down to a considerable depth, but I knew of one case lately where a box-tortoise, prevented from going more than three inches beneath the surface, survived a very cold New England winter without apparent harm. Turtles and tortoises are much less common in the colder than in the warmer latitudes, however.

The last remark is true as well of the race of lizards and skinks; but when they live in a region too frigid for their being abroad, they pass the idle, cold days tucked up in rotten logs and in warm woodland crannies.

The great alligator, indeed, though a resident of almost tropical swamps, is so sensitive to the cold that he hides away under the well-

* "In the retired portions of our upland woods, far away from the muddy ponds and stagnant puddles, and close to the leafy haunts of squirrels and chipmunks, if it be even a little damp, we may chance upon a pretty frog, which in color, habits, and disposition is unlike all others. It is, literally, quick as a flash, and for some reason has a great dread of mankind ; at least it takes wonderful leaps and plenty of them, whenever any one happens to come too near. I know of no harder task than to chase a wood-frog over uneven ground.

“Except in April, when they congregate at some neighboring ponds and lay their eggs, these frogs frequent the woods the year through, feeding on flies and such small fry until frost comes, when they burrow some two feet in damp earth, and there they remain until the weather has become fairly spring-like."-DR. Аввотт. 
caked mud, and is rarely seen between Thanksgiving and Easter, and then only in the sunniest weather.

Lastly, there are the snakes. Like other reptiles, though cold-blooded, they are most common in hot regions, where no dread of snow interrupts the year's business and pleasure. Of what they do with themselves in winter we really have little information, beyond the general knowledge that they hide away in hollow logs, underneath leaves, and in other snug quarters in the woods or rocky fields, occasionally appearing on warm days in a stupid condition. It appears, however, that many serpents have a habit of entangling together in a horridly entwined mass of from three or four to a score of individuals, and thus lying in the midst of brush-piles, straw-stacks, and so forth, until they separate in the spring. This habit has been observed in several American species of serpents, but, so far as I know, no one has been able to explain it to the satisfaction of naturalists.

I myself, and others, have written so much about the expedients by which the feathered people of the woods meet the inclement season, that I fear the briefest sketch of this part of the subject nay seem trite to you; yet if I should neglect the large and wide-awake class Aves, one might justly think I had left much unsaid.

It was an old tradition that certain birds, such as the rail and the bankswallow, hibernated, sinking into the mud in the bottom of ponds, and lying there in a torpor, like so many turtles. This has no proof, I think, to support it, and may be set aside as false. But thongh for many good rensons we may dismiss the old stories as erroneous, there is a reasonable donbt in some cases whether a few birds-notably the chimney-swiftmay not lie dormant in clefts of the rocks, in hollow trees, or nnder the shelter of warm buildings, as do many quadrupeds in underground retreats. 'The reasonableness of this has been argued, and some novel and suggestive evidence towards it has lately been brought forward by Dr. C. C. Abbott. $\nmid$ Nevertheless it has not yet been at all proved that anything approaching real hibernation in a cold climate has occurred, or could be endured by any single bird; and up to the present time it is better to believe that on1 winged visitors come and go with a suddenness and stealthiness so great as to make it seem almost as though, they rose ont of the ground.

* "Friends Worth Knowing." New York: Harper \& Brothers, 1881. Illustrated. Chapter V., Our Winter Birds, pp. 106-140.

$\uparrow$ Science Gossip (London), January to March, 1883. 
Birds, it must be remembered, can move about better than any other sort of animal; and, on the other hand, no class in the whole animal world is so sensitive, as a whole, to changes in temperature. Moreover, the food of most birds being fruit, seeds of weeds, and insects, is such as winter cuts short in northern latitudes. They must starve, therefore, or else go far enongh southward to find something to eat.

The number and variety of the birds to be seen in winter in your district, wherever it may be, will depend on how much food you have for them; other things influence the matter somewhat, of course, but this question of provender comes first.

In the far polar regions no birds can stay through midwinter on account of the darkness. In the nearer arctic lands, like Labrador, January sees only the wildest of sea-birds-ice-gulls, guillemots, auks, etc.which exist by fishing in the open sea. Maine and Canada count more gulls and fishing-ducks; and, as inland visitors, the suowy owl, northern strangers like the wax-wing, the Canada jay, the pine-finch, and the cross-bills; two or three sparrows, and a few grouse. Coming farther sonth, into the northern part of the United States, the snow is rarely so deep or so lasting as to bury all the seed-bearing weeds and bushes, or so severe as to prevent insect-life, at least in a dormant shape, from being accessible to hungry birds.

Althongh the majority of birds seen in the summer are absent, a pretty large number therefore are to be found in the northern as well as the sonthern States throngh all the cold weather-some strange, especially in midwinter, but most of them familiar the year ronnd. I need not name them to you; go ont and look them up.for yourself; find low pleasant and exhilarating a thing a wiuter's walk in the fields may be!

Then if you go so far sonth that it rarely snows at all, and cold winds are rare, as, for instance, into middle Georgia, perhaps you will say, "I suppose you will see all the birds northerners know in summer, and no arctic strangers ?"

No, my friend; that doesn't follow. Many of our small summer' friends, having begnn their southward flight in the fall, do not stop in middle Georgia, or even in Florida, but never lest till they lave gone clear to Central America and the West Indies. One sees not only more birds but more kinds, to be sure, in the southern than in the northern or middle States in winter, but he doesn't see all that he expects to come back northward next spring. This is a curious feature in the history of winter ornithology, for it is just as true of Europe as it is of America. 
In the early part of this chapter I have given a hint of how small landbirds are able to survive our rigorous winter elimate. They lide away, when it storms, in the thick boughs of close evergreen bushes, in hollow trees, and in sheltered nooks among loose rocks and under overhanging banks; or, often, they creep into hay-mows, and under the warm eaves or inside the shutters of our honses. As for the water-birds, they are too lardy to need any such protection; and there are some land species, like the snow-flake, that seem to enjoy the wildest weather. It is not snow and dry cold, indeed, which make birds suffer, but chilling days of rain and sleet.

For food, the winter birds seek the natural granaries left for them along the country roads and at the edge of the woods, where the weeds grow dense, each plant bearing aloft a clnster of seeds ready to be picked; or they search diligently about the trunks and branches of the trees, pnlling dormant insects from snug crannies, and tearing away slabs of loose bark in order to get at the eggs and grubs that lie underneath. The. litthe birds have no lack of food, usually, but the larger flesh-eating fellows have a hard row to hoe in a cold winter. The crows are driven to the sea-shore after shell-fish, the shrikes must use extra skill in seizing titmouses and sparrows, hawks and owls often go hungry to bed, for inuch of the small prey upon which they usually feed keep safe in-doors.

Thus it happens that an unusually severe season is always marked by an extra number of northern visitors and fewer of our own resident birds, since both are forced southward of their usual line by the extremity of the weather. It is a matter of unquestioned record, moreover, that a very cold winter, like that of $1880-81$, witnesses the freezing to death and starration of thousands of birds unable to get away from or endure its rigors. As a rule, however, their wits and activity keep the birds of our winter woods not only alive but apparently very happy; and, in settled parts of the country, more and more are spending their winters with us than formerly, since they find themselves able to get plenty of food about a farm, when, if it were wild land, there would be little or none.

We have watched "fin and feather" through the bad half of the year, and now let us see how "fur" stands it. Here, as before, the amount of change which takes place in the labits of four-footed beasts, large and small, depends on whether the place where they dwell lies in a cold or in a warm latitude, and also on what animal you have in mind; for here there is less uniformity in respect to the way they meet winter than obtains among the humbler classes, where individuality is less developed. 


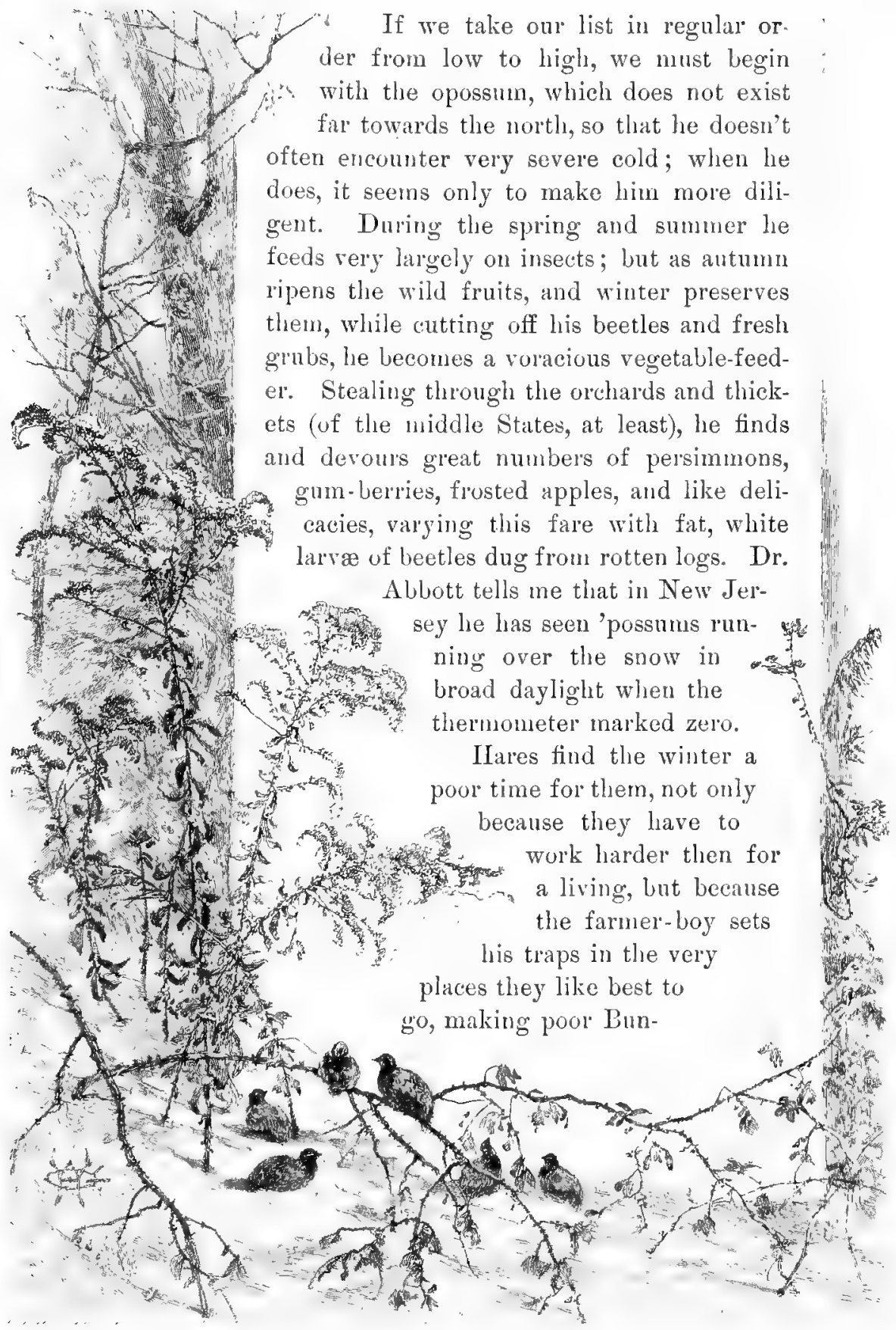


ny's life a constant dread of being suddenly snatched up by a spring-snare, or half crushed under a figure-four. There is a kind of hare which lives out-of-doors all winter, even in the farthest arctic lands, when it wonld seem that everything was buried in snow. The little fellow knows how to get down to the grass-roots, however, and never wanders too far from the stunted red willows that grow along the river banks, and whose bark leeps him alive. Bark, indeed, forms the staple of hare food in winter, as you will quickly learn if you plant a young orchard.

The field-mice, however, which are not always asleep from December to March, do a great deal of the damage charged to the hares. The mice have galleries under the grass-roots and the hollow roots of old trees, where they store away supplies of grain, seeds of grasses and weeds, etc., upon which to live until spring. Not content with this, however, they push tunnels in all directions under the snow, and nibble the tender young bark of small trees. The wood-rats do not make nnderground galleries, but pile up in the woods a hollow heap of sticks and leaves, where they store their nuts and seeds and endure the cold weather; while the house of the musk-rat, constructed of marsh-grass and rushes, stands two or three feet high above the reedy strip at low-water mark, and is able to bear your weight. This house lias a door-way beneath the water, so that the occupant can pass out and in, even though the river be covered with ice, and so reach the aquatic plants and the Unio clams on which he lives. Sometimes the musk-rats make burrows in the banks instead of bouses outside. How the beaver builds himself a strong winter's home inside his artificial pond, or inlabits a snug burrow in quiet all winter, is also so well known to you that I can hasten on to the woodchuck, gophers, and chipmunks.

These gnawers dig burrows and make galleries underground like larger mice, and like them stay therein during the bad weather, tacking their furry tails a little closer abont them in freezing days, and on very pleasant ones coming out to get a bit of sweet air. You know the old tale about the woodchuck's showing himself on St. Valentine's day, to see whether he can venture to stay above ground "for good," or must go back for another month.

The various ground-squirrels, gophers, spermophiles, and their kin, all lay up in their subterranean burrows stores of seeds and other food; but they speedily fall into so lethargic a coudition of almost perpetual sleep that these are not greatly drawn upon, so that the comparatively small amount gathered in the autumn is able to last through to spring.

The arboreal squirrels - true squirrels-make for themselves snuggeriez 


\section{in hollow trees, or ball-}

$\because v_{3}$ shaped nests anong the

aranches, where they can find

grood protection from the weath-

er when it is at its worst, if they

choose to avail themselves of it, which is not as often or as continuously as one would expect of them. The flyingsquirrel seems to lay up the least provision in the cupboards of the decayed tree when he and his many companions take up their winter-quarters. Hence he is often abroad foraging, and one of his favorite tricks is to enter the garrets of granaries and honses in search of corn and small nuts.

The red squirrel, or "chickaree," on the other hand, is the most provident of the whole race, collecting in its favorite hollow tree large hoards of nuts, acorns, corn, seeds, and so on, "wherewith to consule it and sustain

itself in the uncomfortable season of frost and "1) snow" Sometimes, according to Kenandere larders are made under

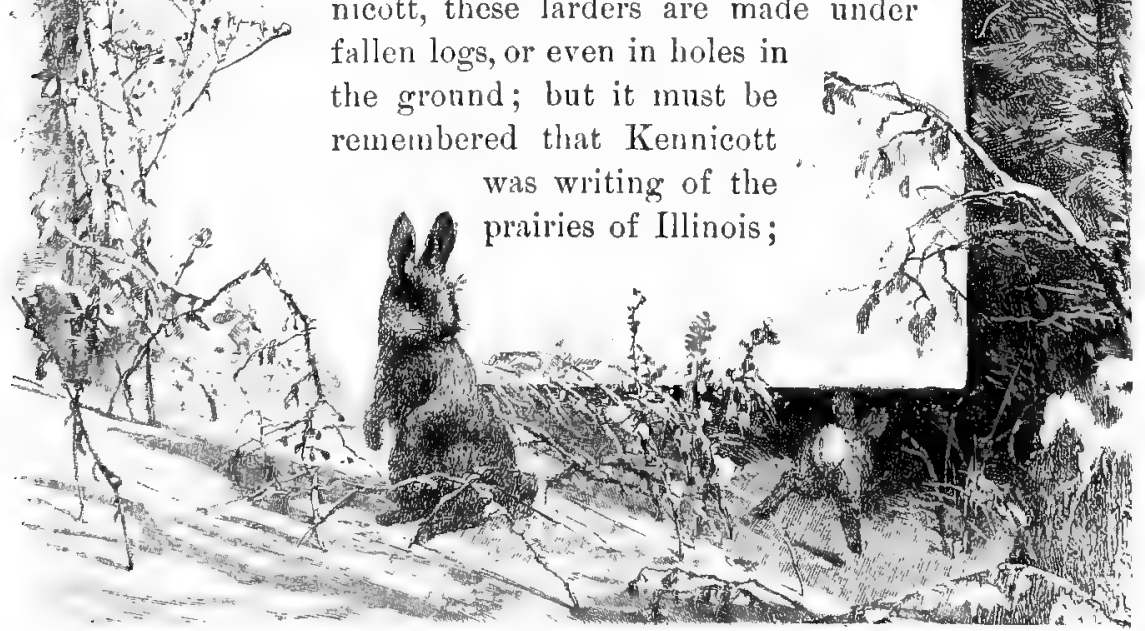


in a wooded region such exceptions would be extremely rale. "In consequence of his good cheer, this squirrel is seen actively scampering about in cold weather, when his hungry cousins cannot plnck up courage to leave their warm abodes in search of food."

By "hungry consins" I mean the gray and the fox squirrels.

Living in the hollows of old trees and in woven nests of leaves and grass, they do not hide in their homes food for winter nse, but bury great numbers of acorns and nuts, one by one, under the leaves all about the neighborhood. These are dug up; and no matter how deep the snow may be, the squirrel knows, or has a way of finding ont, precisely where each morsel is hidden. It is interesting and amusing to see them dive into the fleecy drift, disappearing from sight in a twinkling, to reappear a second or two later with a nut in their claws. It has been suid usnally that they remembered where each specimen had been buried; but from their behavior I do not believe this, for they seem regularly to seek out the place of each deposit, and to know for certain when they have found it. Whether this is done throngh their sense of smell, as their actions seem to indicate, or by some other means, remains to be proved.

When the snow is very deep, however, the squirrels do not depend much upon these buried stores, but search diligently for such nuts and mast as may still cling to the branches, and they eat many berrics, buds, or even bark. Sleet and an icy crust are their worst canses of dread, and when the woods are encased in icy raiment the squirrels are often hard pressed for sustenance.

Shrews and moles, living ehiefly undergronnd, have a natural refuge from inclemency of climate, and none of them become torpid. The mole (I mean the shrew-mole, Scalops aquaticus) appear's to be less active in winter than in summer, but this may be partly because he is then obliged to burrow so deeply beneath the frozen top-soil that his work is imperceptible. Godman remarks that at that season moles resort to the vicinity of streams where the ground is warmer, and says that in the Sonthern States traces of them may be found in the fields all the year round. The moles, nevertheless, are not so hardy, nor ever so actire in cool weather as the shrews, which, notwithstanding their diminntive size, wander to far more northerly latitudes, and treat with defiance the most severe cold; these little animals, however, do not force their tunnels throggh the soil, as a rule, but run galleries under the matted leaves, and make for themselves winter larder's of seeds and dead insects beneath old logs and refuse-heaps. The hibernation of the star-nosed mole is only partial.

As for the bats-also insect-eater's-they get so bennmbed and torpid 


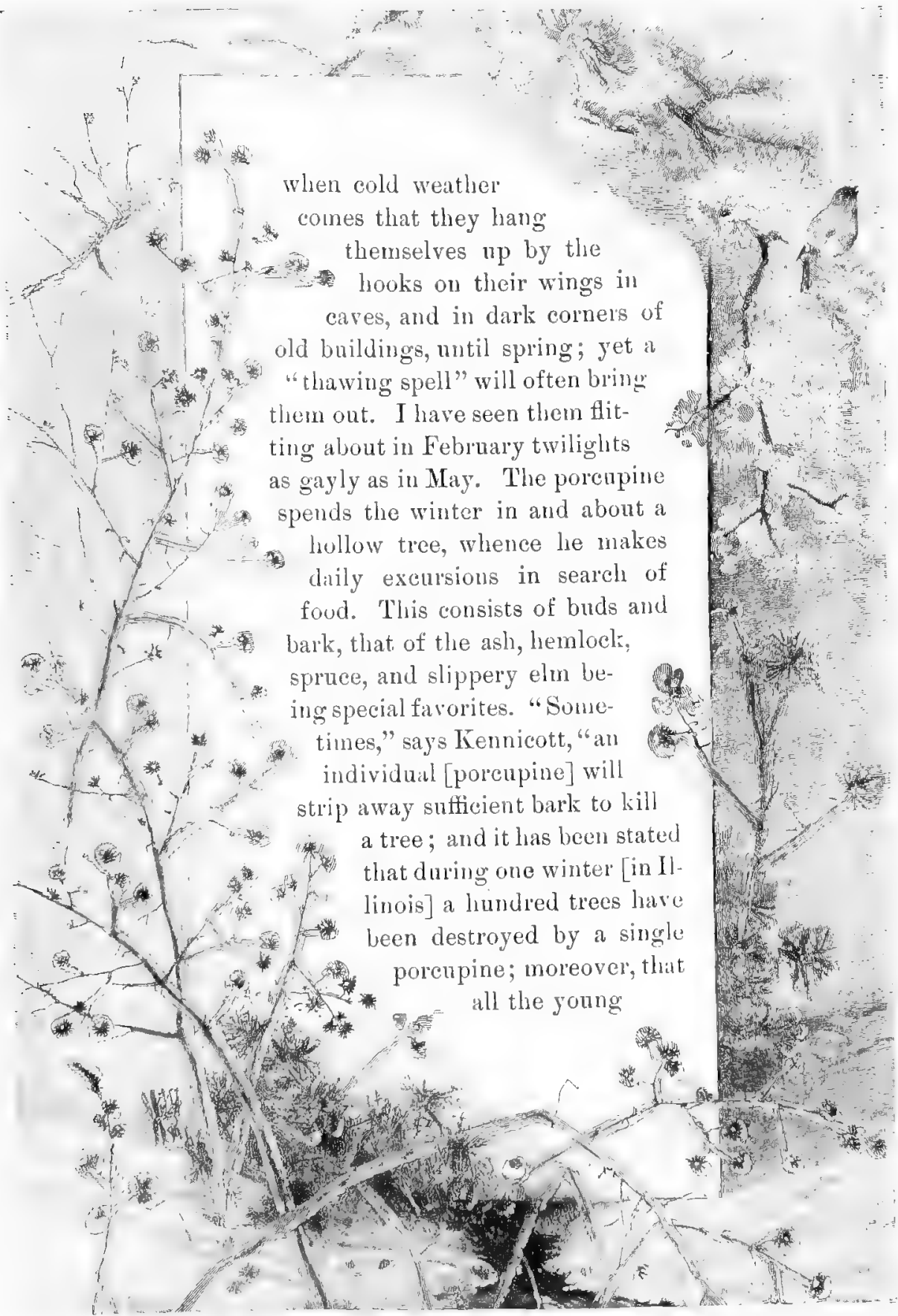


trees on two or three acres of woodland have been killed by two or three of these animals. Usually, however, they are not so destructive, and in western New York they rarely kill trees at all, though they greatly injure them."

As for the deer, none of them, you may be sure, go to sleep in winter. In the far Nortl they retreat from the wild wind-swept " barren-grounds," where they have been pasturing, to the protection of the forests. There the reindeer, moose, and caribou will scrape away the snow in spaces, called "yards," where they can get at the grass, browse leaves, and lie down without floundering in the drifts. The wall of untouched snow abont these yards is sometimes many feet high, and the animals so dislike to leave them that they grow thin and almost starved before the spring comes. The mule-deer of the Rocky Mountains find little sheltered cañons and nooks among the foot-hills, where the wind incessantly blows the snow away from the grass, and where overhanging rocks or clumps of thick sprnces make a shelter at night. The mountain sheepto whom winter is of small consequence-do the same thing on the high plateans near the limit of timber growth.

Elks and antelopes, like the smaller deer, often gather in winter into great herds of hundreds or even thousands, and roam on the plains or in the mountain valleys, finding pastures from which the dry, powdery snow has been blown away, and there seem not to heed the bitter temperature. The same is true of the buffaloes; but it is at such times that the weak animals fall a prey to famished wolves, following the herds as their only hope of food. Our Virginian or common eastern deer does not encounter so tempestuous or snowy winters as his fellows in Canada or the Rocky Mountains; yet lie is often driven by hunger to come close to the farmhouse, and even to visit the lay-stack. All these deers have a longer, warmer growth of hair in winter to serve as an overcoat, and the fat they amass in the autumn out of the hearty living then enjoyed ekes out their scanty provender afterwards.

Of bears we see very little in winter, yet they are nore or less abroad. Bears have sheltered places in the woods, particularly in a mountainous conntry, where they can creep under ledges and find a warm bed of leaves that the winds have drifted in. Here they curl up and sleep during cold seasons until the weather moderates or hunger forces them out. The old books will tell you that bears suck their paws to keep alive, but they must have more substantial dinners than that or they will starve. The polar bear has the hardest time, and the females of these monsters of their race often lie where they are snowed under. It used to be thought 
that they did this purposely, but it is now known that it is more truly an accident. Sometimes they cannot break ont of this snowy cavern, and die of starvation, or are so weak when their prison melts that they can hardly stand. They do not smother, because the heat of the body

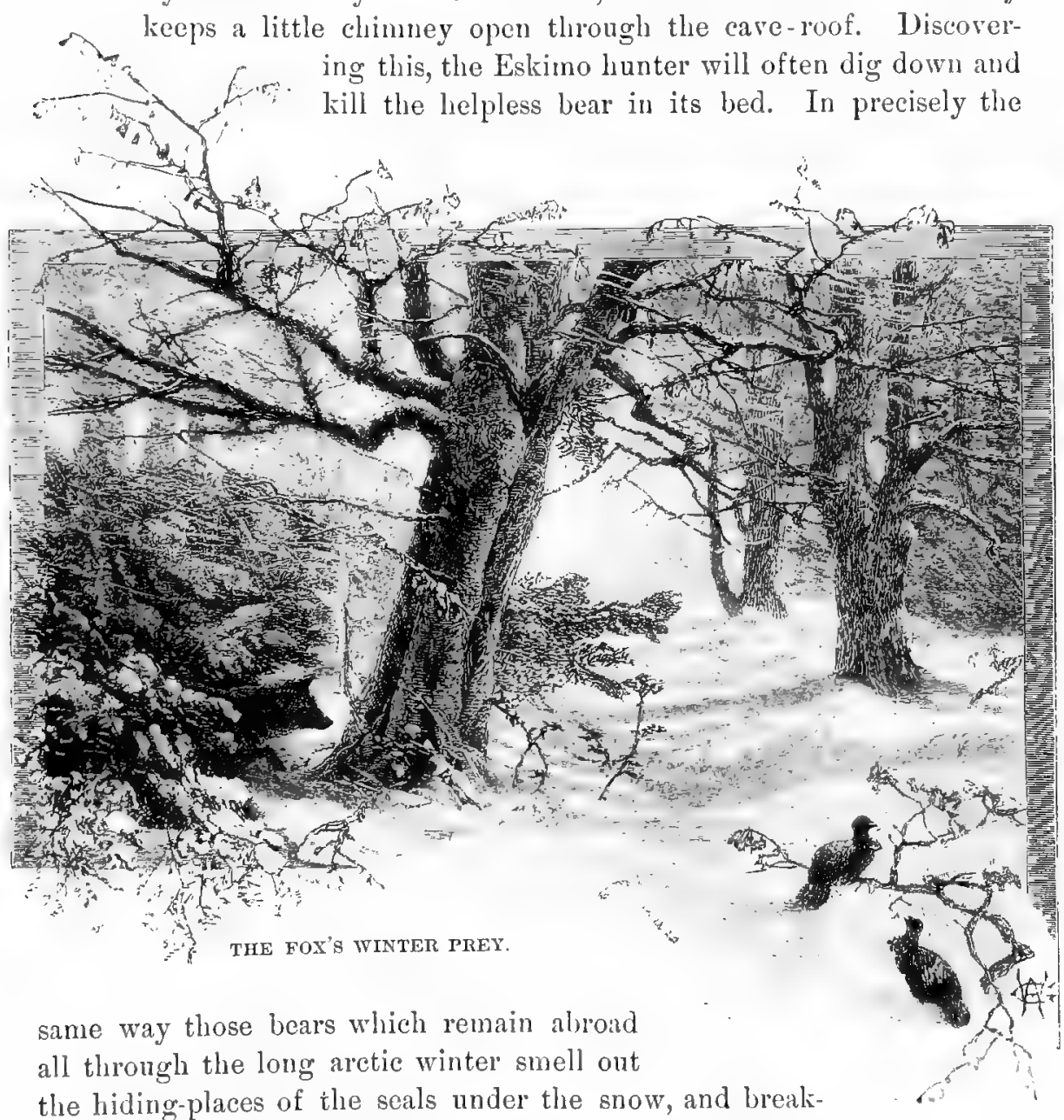
the hiding-places of the seals under the snow, and breaking them in, seize the seal or its young ones, unless they are quick enough to drop through the hole in the ice kept open near by, and so escape into the water. Ilibernation is a word applied more commonly to bears than to any other kind of animal, but nowhere is the phenomenon more partial. Many baby bears are born in the winter retreats, but they increase in size excedingly little until late in the spring. After the bears, come forward the otters, skunks, badgers, wolverines, 
and weasels, each of which conld tell an interesting story of its winter life. The otter, an inhabitant of the water, and feeding on fish, keeps a passage open to his burrow in the bank and does very well; the fishermarten is much like lim. The skunk, on the other hand, curls up and dozes, with few meals, in some warın nook, whence he now and then makes a foray upon the farmer's hen-house, wilder food failing.

The badger has his home underground, and belaves much like a woodchuck, but the great wolverine ranges about in senrch of partridges crouching under the spruce bonghs, hares asleep in their forms, ill-protected poultry, and carrion. He is a savage, ngly beast, and annoys the hunters of the northern woods and plains by destroying their traps and stealing the bait. As for the martens and weasels-who ever caught a weasel asleep, winter or summer? They have their holes in the rocks, where they go to rest and get shelter, but they are abroad every night, as mnch in January as in Jnne, seeking prey. The same is true of the wolves and foxes, wild-cats and panthers, which bring us to the end of the list of North Ainerican quadrupeds.*

But before closing this hasty review of animals in their winter-quarters, I must not forget to call attention to the fact that in many of the fur-bearing quadrupeds the hair changes from its summer brown to pure white in winter. The most notable instances of this are the arctic hare, the various reasels, ermines, and martens, and the arctic fox; the polar bear is white all the year around.: The same change affects the plnmage of several arctic birds, snch as the ptarmigan and snow-bunting. In the case of all, however, this occurs only in the inost northerly examples, since specimens of the same species remaining in the south turn white only to a small extent, or not at all, at the approach of winter.

* Exceptional seasons are marked by extraordinary occurrences not only, but often have a lasting influence and effect. Professor N. S. Shaler wrote an instructive article on this head in The American Naturalist, vol. vi., 1872, p. 671, to which inquiring readers are referred. 


\section{VIII.}

\section{AT A SEA-SIDE LABORATORY.}

QTUDENTS of the geographical distribution of animals find that the key-word to their department of science is temperature. That is to say, the most important of all those combined circumstances of food, altitnde, soil, etc., which affect the localization of a species, or cause a fauna to be made up as we find it in any particular district, is the matter of average heat and cold. This is particnlarly true of marine organisms, which, in a general way, are not only less active in winter than in summer, but far more abundant near the surface-both in variety of kinds and in number of individuals - than at chilly depths, and in warm waters than in northern and colder seas. The Gulf Stream, therefore, forms a very important factor in estimating the distribution of the animal life of the ocean, since its warm current permits many a southern form to wander $f_{a l}$ to the northward in its genial track; just as, conversely, a range of ligh mountains, such' as the Rockies, enables many a snow-loving animal to creep almost to tropical limits along the lofty ridges, defying by the aid of cold altitudes the arbitrary limits which latitude used to set to the "zones" of organic life that were supposed to encircle the globe.

There is thus fonnd to be a startling difference in the oceanic fauna north and south of Cape Cod; the bather who has tried the surf at Nahant and then at Newport needs no thermometer to understand the immense contrast of temperature between the two coasts. The reason is plain : into Massachusetts Bay pours the icy flood from Labrador and the berg-hannted banks of Newfoundland, while the south shore is washed by the great tepid current from the tropics, which the Cape swerres off until it strikes straight ont to sea to warm the Irish coast. North of Cape Cod, one picks up on the beaches, and dredges from the bottom of the bay, few sea-animals (at least of invertebrates) except those of arctic habit, and these grow more abundant as he proceeds northward; while he misses dozens and dozens of species that he knows may be collected merely by crossing the narrow peninsula which has stood for ages, in some shape, a 
barrier to the southrard extension of northern forms, and to the northward travel of those animals whose home is in the sonthern seas.

The naturalist, then, who wonld study to greatest advantage the pelagic life of our part of the Atlantic must go south of Cape Cod; and if he proposes to remain in New England, he is practically restricted to the months of Buzzard's and Narraganset bays, since the coast of Long Island affords few advantages for his pursuit, and the Sound is too landlocked. It was with an appreciation of these facts that the late Professor Louis Agassiz fixed npon Penikese Island, near New Bedford, Massachusetts, as the site of his Summer School of Natural History; and the profusion of species of marine animals and plants procured there proved his wisdom, so far as the question of locality was concerned. When Professor Agassiz died, however, and his son and successor at the Museum of Comparative Zoölogy in Cambridge, Mr. Alexander Agassiz, undertook to continue the enterprise and pursue his own investigations at the sane locality, he met with difficulties.

It was discovered that, owing to inaccessibility and other circumstances, the expense of continuing the school would be too great to make it profitable in any sense, and that the oversight of so large a class involved a greater tax upon his time than Mr. Agassiz conld afford. The school was therefore closed, and a position was songht which should be equally rich in material for study, but more convenient for the erection of such a laboratory as is about to be described - a laboratory which should not attempt to carry out the widely educational idea of the elder professor, but should simply be the best desirable workshop for Mr. Agassiz and such of his assistants and advanced special students at the Cambridge Museum as lie could find accommodation for. These facts are plainly stated in order to dispel a current error that the present institution is only a weak perpetuation of Professor Louis Agassiz's school at Penikese in 1873.

After very careful examination, the terminus of the Neck, at Newport, Rhode Island, was fixed upon by Mr. Agassiz as the nost suitable location. Here a promontory of solid rock, well clothed with turf, stands out boldly from the coast-line. With the open ocean westward and in front as you look towards the sonth, and the entrance to the harbor, divided by Conanicnt and other islands from the shining breadth of Narraganset Bay, beside you on the right, few points on our coast or any other give a more inspiring outlook. In 1812 some defensive earthworks crowned the bluff, giving the name Castle Hill to the promontowy, the crest of which is now occupied by Mr. Agassiz's summer home. On the 
harbor side, at the bottum of the hill, a litte winding cove "makes in "a mere rift in the rocks, su deep that no unsightly mud-banks ane left exposed, and where bouts can easily make a landing at lew tide. Mere stands the laboratory, sheltered from the ocean's winds, but vierlouking the beantiful harbor.

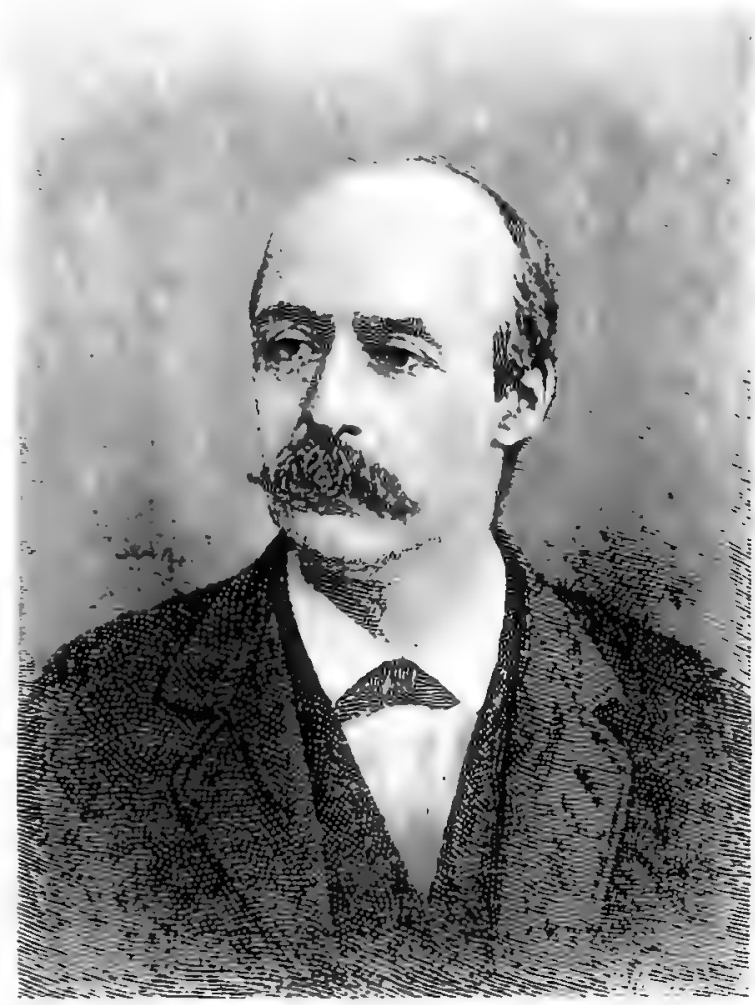

ALEXANDEIR AGABSIZ.

No one wonld snspect its purpose from the appearance of the build-

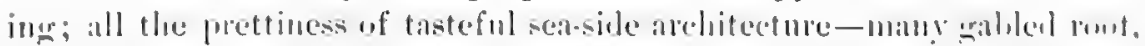

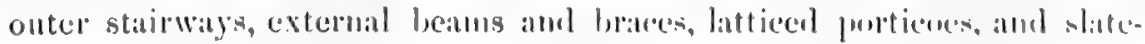
brown paint, overgrown with masses of vinery-feigns romance rather than the realism to which it is devoted. A few rods away, nearer the

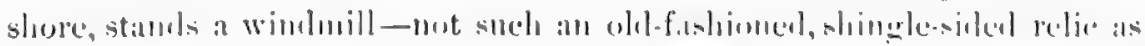
those which used to flap their massive arms in the face of frightened

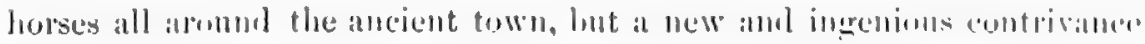
of iron, which, if it alds nothing to the fair pieture, at leilet deres not 
disfigure it. This refinement of a windmill, moving readily under the tonch of a zephyr that the nerves of the old Hollandish structures never wonld have recognized, supplies to the laboratory the pure water and steady currents of air that preserve its vitality. The soft clucking of its musical motion is rarely silent, for day after day the soutl-west summer breeze comes lazily but steadily in, as though Newport lay under the track of a trade-wind.

Out from the windmill, some twenty-five yards into the harbor channel, runs a pipe which is bent up vertically at the end, and capped with a pair of T's, through the screened, hanging tips of which the clean seawater is sucked in, in snch a way that no sea-weed can enter and clog the pipe. Through this pipe the windmill will draw ten gallons a minute, at a moderate speed, pumping it into a cistern in the attic of the laboratory which holds abont one thousand four hundred gallons. When this is full, the overflow-for the mill goes on regardless of the demand-escapes into an open sink down-stairs, so that the condition of the cistern is always apparent. The water used in the laboratory, however, does not come by direct flow from the bottom of the cistern, but is drawn through a siphon. This secures the regular pressure, and avoids the variation of "head" at different stages of water which would result from the other method. This water (as I have already mentioned) is all clean sea-water, salt as the open ocean, and is incessantly renewed.

The windnill also drives an air-pump, which forces the air into a drum, whence it escapes to the laboratory under an equal and steady pressure (secured by proper valves) of five ponnds to the square inch. These arrangements for a constant and uniform supply of water and air under easy control are the foundation of the facilities here afforded for the continued and successful study of living marine auimals.

There is a large cellar-basement, useful for dissection of great fishes and general stornge, and a third story having a suite of chambers charming for an artist's or other delicate work, for which a good light and the encouragement of pleasant surroundings are needed; but the "]aboratory" proper is a room perhaps forty-five feet long by twenty-five wide, entered from the ground, with which its floor is level on the uphill side of the honse.

The southern side of this room is occupied wholly by glass shelving, closets, etc. A part of the shelves lold the working library-not many books, nor in fine bindings, but in all sorts of languages, full of strange diagrammatic figures and Latin names, of anatomical descriptions and tables of classification - unentertaining volumes to the layman, not at 
all of the sort which form the "summer reading" of the publishers, yet costly and precious, for each one is the monument of months or years of patient labor, and lays bare a little corner of the globe's history unseen before. These plain books are all laid on their sides to prevent their warping. Among them are portfolios full of original drawings and manuscript notes that have grown ont of the studies of the master and his students, which are left for years to season under the watchful experience which shall confirm or condemn their presumed truth before the test of publication is risked.

The rest of the glass shelving on the sonth wall is covered witl glass dishes of all kinds. Room is precious, so the cupboards lave doors of slate which, when shut, form a black-board (every working and teaching naturalist must of necessity be a pretty good draughtsman, both with pencil and chalk); and there are everywhere hooks and other devices for convenience.

The eastern and western ends of the room have windows so guarded. by shutters as to exclude the light but admit a cool breeze; but the north wall is full of long windows, having only space between for five tables, which (though there are two, extra ones in the corners) limit the number of persons who can work at one time. This north light is excellent, the bay reflecting it, while the grassy plat near by prevents any glare. Across each window may be placed a movable shelf, fixed at any height, on which a glass jar may be set between the observer and the light, in snch a way that, the motions of any little creatures in this improvised aquarium can be seen with great plainness.

It wonld seem as though a building so well constructed as this, and founded upon the granite core of the primitive globe, was solid enough; but microscopists-and the men who work here are nearly all microscop: ists-will tell you that their instruments are sensitive to $a$ jar which the most acute of our nerves wonld fail to perceive, and that the least tremble is sufficient to disturb that precise focus upon the keeping of which the success of an observation depends. Independent of his foundations, therefore, Mr. Agassiz has built a line of massive arches, nowhere tonched by the floors or walls of the building. It is upon these arches that the working tables and the little three-cornered microscope stools stand, feeling the shock of no gale that may beat against the house, nor the tremor of any footfall upon the floor.

The tables are not of large size-abont like a library desk-but are firmly constructed and serviceable: They are covered with English glazed tiles-white, except two black rows at the end, furnishing opposite 
backgrounds to the glass vessel in which the often almost invisible morsél of animal life is floating. What cannot readily be seen against a white surface may become plainly apparent in front of a black one. On the long middle tables (hereafter described) Mr. Agassiz has enlarged npon this idea by covering them with spaces of variously colored tiles simulating natural sea-bottoms. The clear gray does well enongh for sand; dark leaden gray for unud; a mottled castile-soap pattern in brown for pebbles; and dulse-green for sea-weed. It is a popular error, or, at any rate, prevalent thoughtlessness, that sea animals pay no attention to the sort of bottom underneath them as they move about. If this is true of any, it certainly is not of a large number of kinds. Some are confined to districts limited by one sort of bottom, because it provides their only food; others because there they are safer from harm than they would be elsewhere; a third class perhaps from choice, or for some reason not readily discernible. In any case it has been both suspected and proved that the character of the bottom lias great influence, particularly in the matter of color, upon the fishes and others frequenting a district of mud or sand, or rocky or weed-grown bottom respectively. It was in order to experiment in this direction that Mr. Agassiz invented and provided these imitative surfaces, which shonld form an artificial bottom resembling sand, pebbles, etc., when the dish containing a fish or invertebrate to be deceived should be set upon it.

I can mention here only one of the interesting results of the experiments. The flounder, as everybody knows, is an ill-looking, dark-colored, flat fish, which creeps close along the bottom, and frequents for the most part banks of mud, from which it is almost indistinguishable. Occasionally the flounder resorts to sandy districts, in which case it is of a yellowish tinge, though not otherwise different from its black neighbor of the mud. Taking young flounders, Mr. Agassiz experimented upon their power of changing color. Placing them upon the blackish tiles, they quickly turned mud-color; moved thence to the "sand" tiles, only a few moments elapsed before their leaden skins had paled to dull yellowish white; transferred to the mimic "sea-weed," in less than five minutes a greenish hue overspread their skins, which wonld have served well in their native element to keep them unobserved against a mass of algæ. As the flounders grew older, the rapidity and facility lessened with which these changes were effected, and perhaps they would altogether cease in aged individuals who had never practised as turncoats; bnt the readiness with which youngsters altered their: complexions to suit their circumstances would give them high rank in partisan politics. 
Between the ends of the two tables which, as I have said, extend lengthwise of the room, as far as convenience will allow, stands a sink made of soapstone, where overflows go and where water may be drawn by the pailful. This sink is covered like an old-fashioned well, with a flat canopy of glass resting at a convenient height upon four corner posts, so that jars may be set upon it and their contents examined from underneath with the inportant help of transmitted light.

The central tables each side of this are intended not for study-that . is to be done at the small desks near the windows-but for the preservation of specimens; and to this end there is suspended over them an elaborate system of pipes, supplying air and water and bearing faucets every few inches. This system consists of eight sub-pipes connecting with two branches from the cistern siphon, which hangs well above the operator's head, but within easy reach of the hand. Each sub-pipe may be closed or opened by a stopcock, so as to admit either air or sea-water at will, the air being brought to them by a special connection with the air-main from the windmill. Besides this, a portion of the branches can be cut off and used to supply rain-water also, which is stored in a. small cistern of its own near by. Sea-water, fresh-water, and air may therefore be supplied all at once and continuously, and the arrangement for each may be changed and interchanged to suit the student's convenience, while no anxiety is felt, either lest the supply may cease or lest any irregularities may occur, since automatic contrivances guard against accident to the machinery. Even if water should fly loose, or overflow somewhat, no harm would be done, for copper gutters carry away all drippings, and the cement floor, covered only with neat oil-cloth, defies injury from wetting. In case of a failure of the windmill, the cistern could be filled daily by a hand force-pump.

I have explained that this particular locality is highly favorable to the study of marine zoölogy, because the jutting headlands on each side of the harbor make a funnel into which, twice a day, the entrapped tide drives the pure ocean waters fresh from the warm path of the Gulf Stream, bringing a harvest of living things that elsewhere along the coast remain far outside. Mr. Agassiz is therefore able to get, at the very door of his laboratory, a large series of thoronghly pelagic animals which other naturalists (at least, everywhere north of Hatteras) must go far afloat for, and would regard as wholly extra littoral.

One may see anchored in the little cove behind Castle Hill a small steam-launch (it can outspeed anything of its size at Newport!), a trim sloop or two, and various dories and punts; these constitute the fleet with 
which materials for investigation are gathered. Two methods are practised, according to the sort of animals desired or hoped for. If mollusks, sea-urchins, star-fishes, annelids, or mature non-swimming animals generally, or some kinds of bottom-feeding fishes are wanted, then the launch is sent out to trawl.

The trawl used by Mr. Agassiz is a miniature of the improved apparatus designed by him and employed in his deep-sea dredging in the West Indies on board the Coast Survey steamer Blake. It consists of a pair of U's set on edge and fastened in that position by horizontal connecting bars of iron. Behind this frame so constructed is fastened a sack of chainnetting or canvas, or both, and in front a sort of bail-handle to which the drag-rope is attached. It is of no consequence upon which side the trawl falls when thrown overboard, since the round ends of the U's give equal runners on both sides; and, as it is pulled along, the weight, position, and blade-like form of the lower bar cause the machine to hold to the bottom, and scrape every easily movable thing into the strong bag which trails, open-monthed, behind. The "feel" of the rope tells the dredger when it is full; it is then hauled up hand over hand or by means of a windlass, and its contents are emptied ont and sorted before the next load arrives. Dredging in Newport harbor, or, as we used to do it back and forth throngh Vineyard Sound (to the great pertnrbation of weak stomachs), is a very simple matter; but when it comes to dropping the great deep-sea dredge two miles or more, and taking all day to the experiment, with the. lielp of a donkey-engine, it becomes an art. In the two cases the apparatus differs little, except as to size and strength.

The laboratory I am describing, however, is connected, thins far, mainly with inquiries into the embryology and youthful life of fishes, and the embryology of radiates, crustacea, and worms. Materials for this, in the shape of egys and larvæ, are almost wholly to be got just under the surface of the sea, where the wandering, playfnl children of all sorts of sea life-fishes, mollusks univalve and bivalve, crabs and shrimps, jellyfishes, sea-stars, urchins, worms, etc., etc.-swarm and drift in happy aimlessness until their ranks are thinned by countless enemies, and the survivors sink to safer depths or settle on some public and pre-empted homestead among the surf-showered rocks. When the glare of the sun has left the water, and the tide stands high off the Torpedo Station, or is just beginning to settle seaward at Beaver Tail, the professor and his students. slowly cruise in search of such tiny prey. Behind them is towed a gauze net, which skims the surface and ingulfs every unlucky midget in its path, while all hands continually dip np at random gauze dipperfuls of water. 
and carefully rimse their nets in the sinali tubs, on the chance of getting sornething worth laving. It is by this sort of pleasant sea-prospecting that we have learned how rich are the tidal currents setting into Narraganset Bay in representatives of all the crowding pelagic life of the Gulf Stream; and if Mr. Agassiz neglects to drag his nets on the inconing tide, it is a small matter, for the outgoing rush leaves a thousand sea-born youngsters captives in the pocket-like cove jnst under his windows, where they have been entrapped and may be scooped up at leisure.

Returning from such an excursion, the brckets and tubs containing the "net result" are brought to the laboratory and sorted out. The visitor" then would find the long central tables covered with glassware-jars and pans and bowls, white and clear as crystal, capacious as if to hold punch for the Chaplain of the Fleet, every one with a mouth as big as its:body, or even bigger. Some of these high, straight-sided, flashing jars will hold several gallons; some of the shallow ones are like six-quart milk-pans, and the sizes of the others lessen to the minimum of a watch crystal, where a single egg, or gastræa larva, or dancing animalcule may be isolated from his fellows. This glassware is all made to order for the laboratory and for the Cainbridge Musem. It is altogethes unequalled for the purpose, since it is capacions, clean, transparent, and not affected by sen-water as metal or wood wonld be, while.it is cheaper, lighter, and more handsome than poreelain.

Having roughly sorted and cared for the dyedgings that same night, the next morning the student examines them more carefully, and arranges for preservation the specimens which he especially desires to keep alive. The method will depend upon the age, character, and known hardihood of the object, but the two requisites in all cases are cleanness of water and constant aëration. Turning off the water from one of the pipes, a rubber tube from the air-main is led to it, and it becomes an air-pipe. The jar containing the living specimen is placed on that part of the table at which, by means of the tiles underneath, it can be seen to the best advantage; a sinall rubber tube attached to a faucet on one pipe is made to supply to it a steady stream of clean sea-water, and another tube brings fresh air to replace the oxygen exhansted by the animal's respiration; the overflow takes care of itself, and there is no further trouble.

But this simple proceeding can be trusted only in the case of large, mature, tongh animals, such as rarely have the honor of reposing in these scientific precincts. More gentle treatment is usually required, and the methods now successful have only been learned through long and costly experience. 
In the first place, isolation, entire or in part, is necessary. This is accomplished by subdividing the tubes which lead from the iron pipes overhead. An inch or two from the fancet there will be slipped in an inverted $T$ of glass bearing two tubes; these in turn may be similarly subdivided by inverted T's, and so on, the number of outlets supplied by the one original faucet and neck being limited only by convenience. Every terminus of a tube, whether delivering water or air, is closed by a glass tip, which not only gives exit to a safely diminished stream, but does no harm to the inhabitants of the jar, as the corrupting influence of rubber in contact with salt-water might. 'These tips are bits of glass tubing cut off as required, melted in a spirit-lamp, drawn to a fine point, and perforated by a hole, which allows the escape of only a thread of water or a bubble of air so small as to cause no disturbance. Each man makes these glass tips for himself, bending and twisting them to suit his needs. The rubber tubing, too, is a great convenience. It is of various sizes, can be cut into any required length, pieced out by stretching over a joint of glass tubing, fitted air-tight upon iron pipes, faucets, glass rods, and the like, and bent about in the most handy and time-saving way.

Though the water comes clear enongh, it will not do to allow the air supplied by the windinill to enter at once the water in which the very delicate organisms are being kept alive. It is likely to contain some moisture gathered on the way, and this moisture is liable to bave been charged with irou-rust or some other mineral ingredient, The air from the pipe, therefore, is led first through a large Woulfe bottle, such as chemists are familiar with, where it leaves its deleterions moisture and goes clean to its work. That this precaution is a judicious one, is shown by the fact that the Woulfe bottles gradually become clonded within by a deposit of iron and dirt. Sometimes ducts of rubber connect two or three jars to one or more of these Wonlfe bottles and to each other, and so there is a constant circulation among a community of little aquaria, economizing apparatus. All these contrivances together, and two hundred and fifty jars and bowls, can be taken care of at once on these tables, though there are only a seore or so of supplying fancets.

Reckoned by their vitality in captivity, marine animals fall into three categories :

First.-Those that are large and strong enough to allow water to be introduced in a steady stream directly to their jars, and that do not require any more air than the constant current of water brings; these are the crabs, shell-fish, annelids, and common full-grown shore animals, such as are ordinarily seen in aquaria. 
Second.-Those that will survive simple aëration of the water in which they are placed, the water itself not being changed, usually, but only added to to make up for evaporation. To this class belong crabs and other small animals that are just about to lay their eggs, together with young of all sorts in their swimming or larval stages. In these cases, however, the "injector" is often made use of. This consists of a spindle-shaped chamber of brass, with external openings, so that, as the stream of water passes throngh, it sucks into its crurent a quantity of air which goes to the jar mingled with the stream. This little injector is, in fact, a miniature Catalan blow-pipe, being constructed on exactly the same principle as that which supplies the tweers of a blast-furnace. It is a contrivance of great value in the laboratory.

Third.-The morsels of almost invisible life, too delicate to resist ever so feeble a current, and too volatile and minute not to escape in an overflow, however well guarded. To the receptacle of these only a very gentle thongh unremitting supply of air can be given, while the water must frequently be changed by cautious dipping out and pouring in by hand, a trifle at a time. No mother attends to her infant with more tender" and scrupulons care than the zoölogist to these babies of the sea.

And what are they? Eggs of tishes, mollusks, crustaceans, and radiates; embryos of similar animals and of jelly-tishes-filmy, fragile, nineteen-twentieths water-which would perish under the slightest injury, and can only be kept alive by the greatest painstaking. That Mr. Agassiz has been successful beyond all precedent in preserving these excessively delicate pelagic forms in bis laboratory, shows how admirable are all his methods and appliances to reproduce the most healthy conditions of nature. It was no mean triumph, for instance, to have reared those young flounders and goose-fish from eggs scooped up in the open sea, and to have kept them all summer, while he noted and sketched the various aspects of their growth. But the highest surety of the suitability of his arrangements was afforded when the vapory, translucent siphonophores, in which no one before had been able to maintain vitality for -more than two or three hours, lived contentedly in their glass prison last summer during fifteen days. One highly favorable circumstance, no doubt, is that the temperature of the water in the Newport laboratory is cooler than that of the open sea. Heated by the ever-present Gulf Stream, the ocean in summer rises to a warmth of seventy-six or seventyseven degirees Fahrenheit; by the time it has passed through the pipes and the shaded cistern this water has been considerably cooled down, and -jemains at a lower temperature than that of the native element from 
which the subjects for study are brought. This is greatly to their advantage (the hatching of fish-eggs may be checked, yet without loss of vitality, and held back indefinitely, by steady cold), and it was because of the opposite condition that sea-side students at Nahant and Salem and Gloucester have always been less successful. English laboratories have an equal difficnlty, overcome only by the expensive use of ice.

But to go into all the details of laboratory expedients employed here is beyond space, and perhaps would interest very few. Everything is intended for work and study, not for show; there is nothing in the way of an "aquarium." If it heppens that the apparatus or the zoölogical speci. mens are pretty, that is a happy chance, not the first intention. No living object is kept longer than there is use for it: mere curiosity must make way for original investigation into something else more obscure.

The studies at the laboratory have continued throngh half a dozen summers, and have been conducted by Mr. Agassiz, the late Connt L. F. de Pourtalès, Professor Walter Faxon, Dr. W. K. Brooks, and Mr. T. W. Fewkes, with a few others at intervals.

Mr. Agassiz's work here has been mainly on the embryology of fishes, radiates, crusticea, annelids, and pelagic tunicates. Several contributions to the National Academy of Science and to the Proceedings of the American Academy of Arts and Sciences (Boston) bave grown ont of them, chiefly upon the young stages of flounders, goose-fish, and various other genera; and embryological observations on the ctenophoric jelly-fishes; on the gar-pike (Lepidosteus), and on Balanoglossus. Mr. Agassiz was also employed for a long time in working up the sea-nrchins brought home by the Challenger deep-sea expedition, the results of. which liave been embodied in the special scientific reports of that famous cruise.

Count Pourtalès spent his energies chiefly on his favorite corals, For aminifera and their kin, publishing his results in the memoirs of the Musenu of Comparative Zoölogy, where he was keeper. Mr. Faxon; who is assistant professor of zoölogy at Harvard, made a specialty of crustacea, and wrote several papers on their embryology.

Dr. Brooks, who is now assistant professor of biology at Johns Hopkins University, and who carries on a marine laboratory of his own at Beaufort, North Carolina, busied himself with the embryology of mollusks, publishing one paper. Dr. Fewkes, now Mr. Agassiz's assistant in the Zoölogical Museum at Cambridge, did the same thing with .jellyfishes. Much of the work of these and other students (among them some ladies) remains unpublished in note-books and manusclipt (for " rushing into print" is frowned upon by this cautious coterie), so that future re- 
sults may be expected, the chief preparation for which has already been done. As to the further progress of the laboratory, Mr. Agassiz says the chief tield will naturally be the study of the youth of marine animalsnot simply of their embryology, but of the successive phases presented in the development of their infant growth, and the relations these bear to adult forms and to general questions of biology and classification.

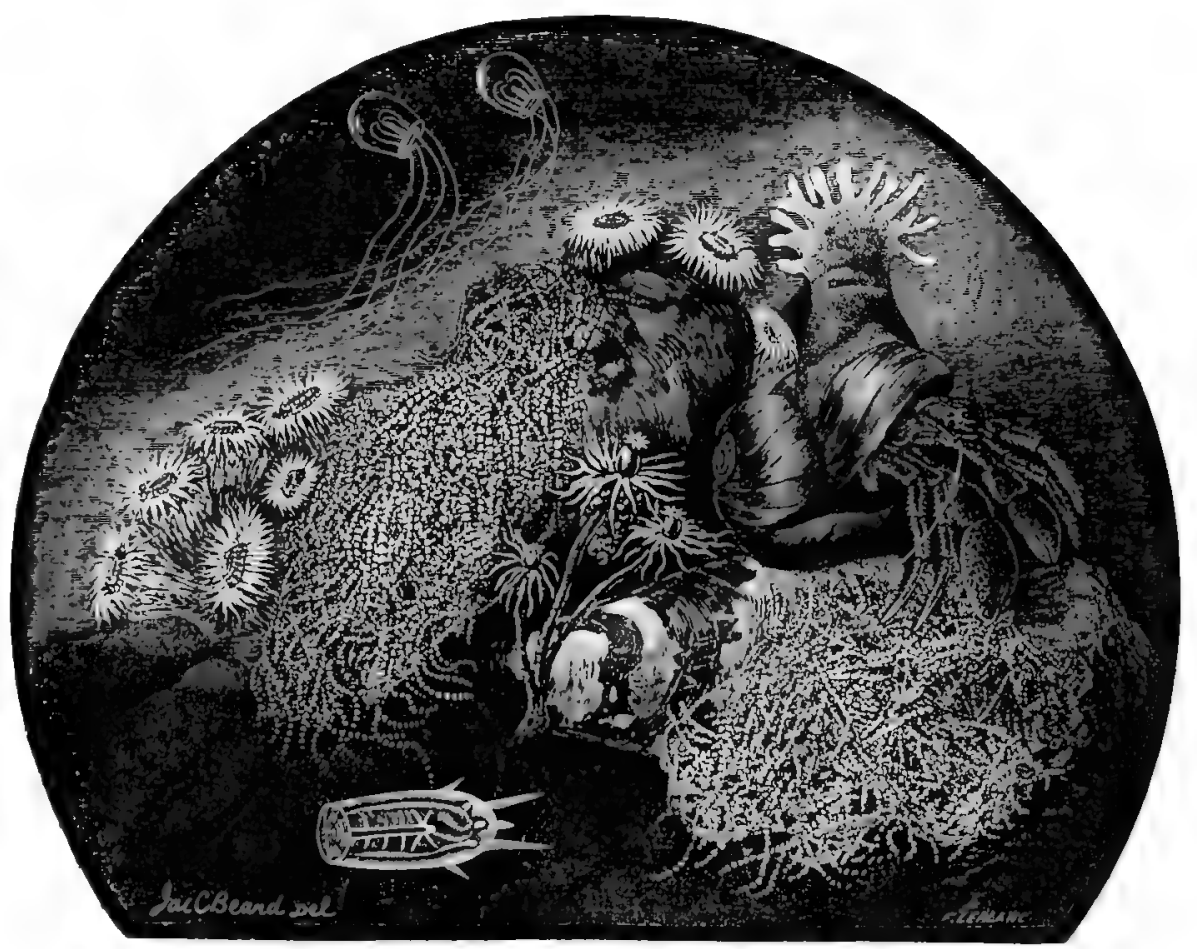

MATEILALS FOR LABORATORY STUDY. 


\section{IX.}

\section{RATTLESNAKES IN FACT AND FANCY.}

TF it were not for the traditionally repulsive idea connected with ser1 pents, the rattlesnake should take the place of the bald eagle as our national emblem. This is not the first time the idea has been suggested, however, since more than one of the colonial flags bore his image.

He is the most thoroughly characteristic of the larger animals of the New World, and one whose behavior both in war and peace is "without fear and without reproach." If any one objects that he is lazy, I reply that he does all that he is called upon to do with proper diligence, and that it is better to be represented by his negative traits in this respect than by the piratical habits of the eagle, who subsists chiefly through plunder. I never yet have seen a man who did not hold the rattlesnake in most thorongh respect.

The rattlesnakes belong to the family Crotalidas, and are confined to the western hemisphere. Four genera, containing seventeen species, are designated in the United States, of which the most strongly marked genns is Crotalus, of Linné. (Crotalia were jingling ear-rings of pearls, and the crotalum a castanet used as an accompaniment by dancing girls.) In the present chapter the eastern Crotalus horridus (formerly C. durissus) is usually meant.

Young rattlers are born in broods of eight or a dozen, early in summer, and remain together until they have well got their growth. During this juvenescence they seem as viciously inclined, and as artful in rattling, coiling, and striking as they ever afterwards become, exhibiting these characteristic traits even when just escaped from the egg, and with the yolk-sac still hanging to the abdomen.

In dull, wet weather, all varieties of this serpent lie quiet and lethalgic, and are then most to be feared; but when the sun shines, the chilly rattlesnake climbs upon the warm rocks or stretches himself in a 
dusty road ; moccasin* and massasaugat creep from their "tangled fens" upon hard banks or low-drooping limbs, along whose upper surface they balance their rugged folds; while the copperhead crowns the bowlder at the edge of the clearing with a brazen coil.

There is a popular belief that the snake never eats or drinks during the hot weather, but that this is wrong has been shown by many specimens in confinement; manifestly' it must be, since only in summer can it prepare itself for the long fast of winter hiberuation; while the young must eat to nourish their growth. Dr. R. E. Kunzè, of New York, who kept a large rattlesnake in his office, and wrote an instructive history of it in Science News (1879), found it ate willingly about twice a week, killing the living mice put into its cage and wanting two mice for a meal, with perhaps an hour between them. Other men have had difficulty in inducing their captives to eat at all; they have been known to live a year and a half without a mouthful. They must have water to drink, however-a want they seem to feel keenly in a state of nature, often invading door-yards and even houses in search of it when the woods are dry.

The most noteworthy incident, I fancy, in the career of little rattlesnakes (as well as of other ophidian youngsters), is their occasional hasty retreat into the stomach of the mother as a temporary refuge-a fact which I must ask you to accept as proved, since I have not space to present the abundant evidence substantiating this assertion, and which seems to me thoroughly conclusive.

There is a queer Shoshonee myth which some have thought was inspired by this snake-swallowing, but I cannot see that it ever had anything more to do with it than with the well-known fact of slonghing the skin, nor as much; this is the myth accounting for the origin of the echo, and it is as follows:

Iowi, the Turtle Dove, was gathering seeds, and laid her babe down while it slept. Wandering away at her work, a witch came, stole the boy, carried him to her mountain home, stretched him into a unan, and

* Of this word there are a dozen spellings : it is the Eastern-Indian word for shoe, and is said by Schele De Vere ("Americanisms," p. 35). to have been given to the snake because its markings are "like the black marks of wear and tear on the buff leather."

$\uparrow$ Mr. J. Hammond Trumbull, of Hartford, authority in these matters, writes me that the spelling I have adopted is the one chosen by him for the snake, though he uses mississanga or messissauga for the Indian tribe from which the snake takes its name. This tribe (Chippeways of Canada) is named from a locality-" the great outlet" of the lake. Peter Jones ("History of the Ojibway Indians," p. 164) says messisaga (pronounced by the Ojibway Indians ma-sa-sau-gee) means " the eagle clan." 
married him; but, like Panl Bultitude in "Vice-Versa," though he had the stature of a man he had the heart of a babe. The distracted Iówi and her brother Kwina, the Eagle, searched day after day for the tsóavwits and her victim, and finally got the babe back, retransformed and as lovely as before. The angry witch, however, was bent upon recovering her husband; she said to herself, "Well I know Kwina the brother" of Iowi, a great warrior and a terrible man. I will go to Togóa, the Rattlesnake, my grandfather, who will protect me and kill my enemies."

She found him asleep on ra rock, and he resented both her interruption and her request for aid. While they were parleying they heard Kwina coming, and Togóa said, "Hide! hide!" But she knew not where to hide until the grandfather opened his mouth and bid. the tsóavwits creep into' his stormach. This made Togóa very sick, however, and he begged her to come out; but she refused, for she was in great fear. : Then his retchings became so great that he could endure them no longer, but crawled out of his own skin. The witch, imprisoned there, rolled: about and hid in the rocks. When Kwina came near, he shouted, "Where are you, old tsóavwits? Where are you, old tsóavwits?" only to hear his words repeated by her in mockery. Ever since then witches have lived in snake-skins among the rocks, and it is their mocking voices passers-by hear and call echoes.

The young rattlers grow with rapidity, and attain pretty near theil adnlt size by the end of the year. This, in the horridus, rarely, if ever, exceeds a length of five feet; nor are the other species larger, but rather the contrary, except the southern one (C.admanteus), examples of which, eight feet long, have been seen; while the miliaria and Kirtlandi are less than three feet. All are thick in proportion to their length, with a small neck and the wide triangular head, like the barbed point of an arrow, that gives as characteristic an appearance as does its inflated hood to the cobra, and one equally frightful to human eyes. The amount, pattern, and intensity of the coloring of the hide, made up of hues of livid gray, black and blue black, chestnut, copper red and sulphur yellow, for the most part, vary widely in different species and under different conditions; thus, in dry and open districts, like the great plains, the colors fade into an inconspicuous sameness, harmonizing: closely with the dusty ground and stunted herbage.

In favorable localities rattlesnakes occur in amazing plenty, and the stories, to be heard in every State, of "dens" where they writhe in countless numbers and dreadful intimacy, have some foundation. De Kay cites an instance where two men, in Warren County, New York, about 


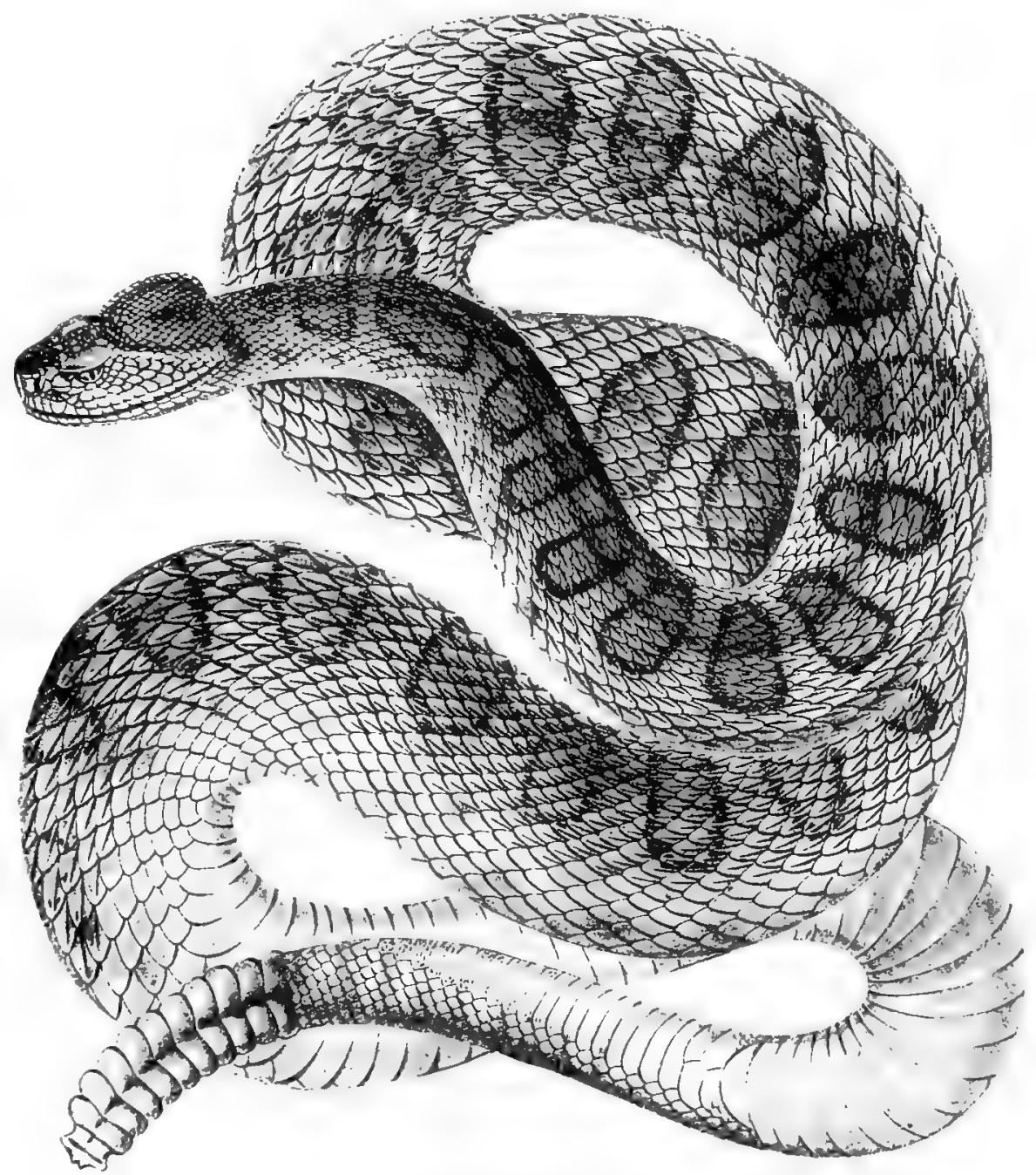

A TYPICAL RATTLESNAKE.

18t0, slaughtered one thousand one hundred rattlesnakes in three days on the eastern sille of Tongne Mountain. In $185 \%$ a furmer killed seventy-six massasaugas in a clanberly marsh of Crawford Cumnty, (H)io, where are still harbored many serpents disappearing elsewhere. Some swamps and canebrakes in the far. Sonth swarm with the drealed cottonmonth, and local species occur in thousands on parts of the plains and Rocky Mountains, particularly in the tufa craters of warm springs, in Ltall. But perhaps the nearest approach to the "den" of the sensational picture is an 
island in Pyramid Lake, Nevada, where, during the warm months, "it is absolutely dangerons to walk abont those parts of the island where they are colonized;" or, at any rate, it was so a few years ago, according to a government report.

This animal is easily killed or disabled, however, and has in man an implacable enemy, not only directly but in many indirect ways; yet there are few localities favorable to him where he has been exterminated. You can find rattlesnakes in plenty, for example, within five miles of the centre of New Haven. It is doubtful if any of the several species will ever suffer extinction.

Scales being undistensible, and never falling ont to be replaced, like hair and feathers (with which they have no homology), serpents get room for growth and renew their coats by periodically sloughing off the entire skin, underneath which a new external skin has formed and separated itself from the now faded and husky cuticle. The process occurs during August in the adult, two or three changes happening in a single snmmer with youngsters, who outgrow their vestments very speedily. It is a popnlar idea that this midsummer slonghing occupies a considerable period, during which the serpents are harmless because blind. It is quite supposable that this might be so, since the onter layer of the cornea of the eye peels off with the slough, and during the few preceding days the eye has a dim and filmy appearance. But captive snakes, given active mice at this time, attacked them without hesitation or missing. After the moult the eye gleans bright and cold like a jewel, but with a sullen, ferocious, and relentless expression, for it is overhung by the bony pent-house of the broad, strong, superorbital bones that give a fulcrum for the powerful muscles of the jaws. This criel eye and its fixed stare introduces the once vexing question of fascination; but before discussing it, some account of the food and feeding habits of our subject will be well.

The disposition of the whole family is sluggish, and opposed to any active movement, even in taking prey, beyond the one lightning-swift blow that smites it down-so startling a contrast to the ordinary lethargy! The moccasin, to be sure, is somewlat an exception, since he is a good swimmer and chases in their element frogs, smaller water-snakes, tadpoles, and the less agile fishes, like the cat-fish.

The most rapid exertions of rattlesnakes are aronsed in fleeing from danger; yet, when doing their best on open ground, their pace can easily be equalled by a child, without running, as I have seen on the plains, so that a blacksnake or a Eutania could not only overtake, but circle round 
and round them. Their plan in food-getting, then, is not to pursue their prey, but to lie in wait for it and strike before their presence is suspected. Protected by his colors, that assimilate him to the haunts he most frequents, whether woods and rocks, as in the Eastern crotali, or the bare uplands chosen by the far Western species; the shaded inorasses threaded by the dark-skinned massasanga; the lush meadows where the copperhead lurks; the streambank or rice-ridge whence the cottonmouth plunges into the water; or the yellow weeds under whose mottled shadows the little groundrattler becomes invisible - hidden and motionless for hours together in one or another of these resorts, the crotalus coils in patient vigilance. "Though aware of the pas-
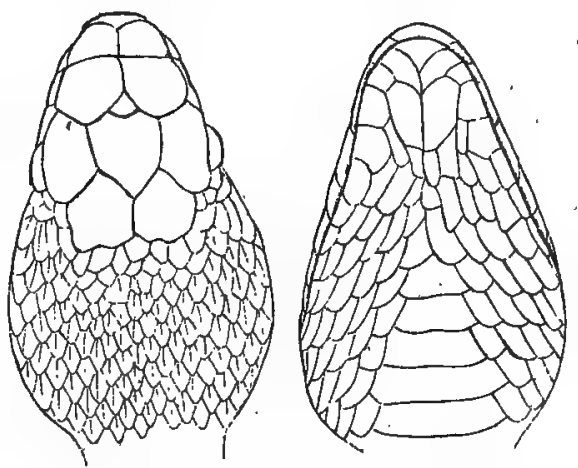

HEAD OF THE COPPERHEAD-UPPER AND UNDER VIEWS. senger's presence, he either lies quiet or glides aray to a more retired spot." His course is that of the darkey who was urged to follow one into a thicket and kill it: "Massa, I nebber bodders nuffin' wot don' bodder me; I makes dat a rule!" Here again, nevertheless, an exception must be woted for the copperhead, and more especially for the moccasin - vicious reptiles, asking little provocation before inflicting their
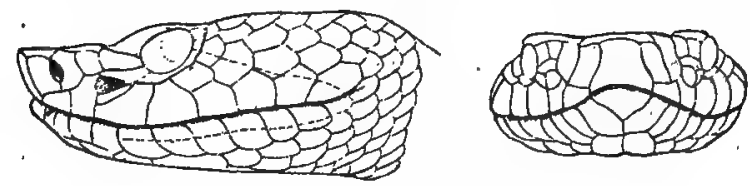

HEAD OF THE COPPERHEAD-SIDE AND FACE VIEWS. deadly wonnd. Holbrook says the moccasin "attacks everything that comes within its reach, erecting its head and opening its mouth for some seconds before it bites." All other snakes put in a cage with it show the keenest terror. No species of crotalus, however, will follow the object of its rage as do some of the non-venomous serpents; and, as a rule, the eastern rattlesnake would rather run than fight, unless hard pressed.

Such are the facts respecting the food-getting of the rattlesnakes, while those of other serpents would furnish an equally prosaic explanation; yet the notion that the small, bead-like eye, and tongne darting forked flame from black lips, exerted a charm or fascination upon smaller animals, luring them within reach of the fatal stroke, is as old as the fa- 
bled basilisk-older, indeed, for to it, no donbt (as $\mathrm{I}$ have mentioned in a previous chapter), the very image of the basilisk owes its origin. Travelling westward, it cane to America with the earliest book-makers, and was at once attached to our sulject and to the blacksnake. "Birds have been seen to drop into its Month," wrote Pennant; "Squirrels descend from their trees and Leverets run into its jaws. Terror and amazement seem to lay hold on these little animals," etc., etc. "All agree," says old Catesby, of South Carolina, who confesses he never witnessed the phenomenon of fascination for himself_- "all agree in the manner of the Process, which is that the Animals, particularly Birds and Squirrels, no sooner spy the Snake than they skip from Spray to Spray, hovering and appronching gradually nearer the Enemy, regardless of any other Danger, but with distracted Gestures and Outcries descend, tho' from the top of the loftiest Trees, to the Month of the Snake, who openeth lis Jaws, takes them in, and instantly swallows them."

Nowadays no well informed person accepts this tale as containing more than the merest grain of fact. It is true that the rattlesnake does lie for hours at the foot of a tree or in other convenient situations, silent and watchful. If he is seen there by any of the small denizens of the woodland it is doubtful if he is recognized at, once as an enemy. I have never been a witness, nor do I recall a record of a commotion in the woods arising from his presence such as follows the discovery of a hawk or owl. When Dr. Kunzè excited his captive snake into a perfect frenzy of rattling and alertness, then bronght his pet squirrel close to the glass front, neither of the animals paid the least attention, the squirrel showing no concern whatever at the proximity and noise of the crotalus. This is by no means an isolated instance of its kind.

In the case of tree-climbing, bush-prowling snakes, which are arrant nest-robbers, the discovery by birds of their young in the marauder's grasp would lead to frantic efforts to drive the intruder away and secure the release of the fledgling. In attempting this with the rattlesnake they wonld flutter abont his head, and probably get struck down as the reward of their noble exposure. This situation accounts for many supposed instances of "fascination."

Cases of another class have often been attributed to an "amazement and terror" at being suddenly bronght face to face with a strong and relentless enemy, that amounts to paralysis and leads to such behavior as Catesby has outlined. But from all that we can learn of the reptile in captivity, and from negative evidence ont-of-doors, no snch recognition of the snake as a foe occurs. This fact, by taking away any cause of 
excessive fright, destroys the argument. Nevertheless it may sometines happen, and, if it does, prostration of nerve would not be surprising. Men have fainted from astonishment and fear. I have seen deers and antelopes, suddenly disturbed, stand stupidly staring or jumping up and down, their wits gone in a panic. Hares, startled froun their furms, sometimes run right towards the gun instead of away from it, or they have been known to drop dead before a shot was fired. The impotence in mind as well as body of a mouse under the paw of a cat; of the hog-nosed snake when you have got it at sudden disadvantage; of the opossum, and inany other animals, when they are involuntarily "feigning death," are all exanples of this physical helplessness resulting from excessive fright on some natures. I am willing to admit that serpents may owe an occasional meal to the paralysis caused by their sudden presence before the eyes of a timid bird or squirrel; but I an confident that no one of these small and gentle creatures, if allowed to recover from its impulsive fright, or gradually introduced to the snake, would ever fall a riction to his fascination, "charm he never so wisely."

The inquisitiveness so characteristic of wild animals might lead them now and then into difficulty with serpents, as it does with other foes to their peace of miud and body. Lastly, if any such falling into the jaws of the rattlesnake was ever observed, as has been alleged, without imaginary additions, did it not follow rather than precede the stroke, and occur under the influence of the slow-acting poison, which left the victim power to flutter for a brief space before falling in the stupor of approaching death? The struggles of a poisoned bird, with the snake lying waiting underneath, would make snch a picture as Catesby drew; and it is a fact that the bite is not always instantly fatal.

It has been thought that the purpose of the rattle-an organ which it has greatly puzzled naturalists to find the true utility of-might be to stimulate the curiosity of small animals, and so attract them to destruction.

The "rattle" consists of a varying number of hollow, flattened, and somewhat rounded segments at the end of the tail, terminating in a more globular one called the "button." These are hinged loosely together, so as to have considerable play, and the number of pieces, as well as their shape, varies greatly in different snakes and at different ages-while the copperhead and massasanga have noue at all, but only a horny tip to the tail. There are records of forty-four, thirty-two, and twenty-one rattles, but ten to fourteen is the ordinary number in full-grown crotali of the 
larger-sized species. They show no accurate index of age, ${ }^{*}$ as was formerly supposed, but may be lost and replaced irregularly, the repair of such an accident proceeding rapidly.

The crepitating sound of the rattles is a mechanical result of their jarring, and may be produced by shaking them in your hand, or accidentally by the animal in moving along uneven ground. This, however, is hardly andible, and the sound becomes so orly by increased agitation of the tail, which can be made to vibrate with singular swiftness. As a continuous and sustained action, this has no parallel anywhere that I know of in the higher animals, and is only approached by the whirring speed of a hummingbird's wings, making mist of their invisible motion while poising before a flower. Similarly the motion of the rattle in an excited snake cannot be followed by the eye, its shape disappearing in a fan of light. The enormons muscular and nervous force involved is shown, also, in the fact that this inconceivably rapid movement of the tail can be sustained for several hours withont an instant's rest, as I have repeatedly witnessed in various species.

What is the purpose of this vibration of the tail and the lond rattling? Does it serve any use to the creature? If so, what?

Naturalists are not agreed upon the proper answer to these questions, but certain facts seem made out, one of which, not to be forgotten, is that many other serpents ontside the Crotalida set their tails into swift vibration when teased or excited. Another point is the close resemblance between the sound of the snake's rattling and the crepitation of the wings of certain cicadæ and locusts. The view has been advanced that the rattling of the serpent was an imitative sound, operating to attract within reach of his fangs such animals-especially birds-as feed upon these

* An odd note in Thomas Morton's "New English Canaan," 1632, is worth quoting : "There is one creeping beast or creeple (as the name is in Devonshire) that hath a rattle at his tayle, that doth discover his age." That progress towards a knowledge of truth was slow, is shown by the following quotation from the generally very intelligent book written by Thomas Campanius (of Stockholm), printed in 1702, concerning "New Sweden," or what is now southern New Jersey. He says: "There is here also a large and horrible serpent which is called a rattlesnake. It has a head like that of a dog, and can bite off a man's leg as clear as if it had heen hewn down with an axe. There are horny joints in their tails, which make a noise like children's rattles, and when they see a man, they wind themselves in a circle and shake their heads, which can be heard at the distance of a hundred yards, so that one may put himself on his guard. These snakes are three yards long, and thiek as the thickest part of a man's leg; they are as many years old as they have rattles in their tails; their color is brown, black, and yellow. Their skins are much sought after by pregnant women; they tie them round their bodies, and are quickly and easily delivered." It would be hard to find a better example of exaggeration. 
insects.* This imitative apparatus, beginning in a tendency to develop buttons or rattles on the tail (originating, as many herpetologists think, in an incomplete shedding of the skin at that part), and in the inherent disposition to wag the tail (which is a channel for the expression of surplus energy in all animals), was accounted for through a process of development by natural selection. This seems to me, as I read it, remarkably unlikely. It asserts prodigious preparation for very small results, since the insects simulated are never particnlarly plentiful where the majority of rattlesnakes occur, taking the whole country across; are noisy only a quarter of the year; and the birds to be deceived form only a small portion of the reptile's fare.

There grows in some parts of the Sonthern States a kind of grass which bears seed-panicles that are so jointed as not only to resemble somewhat the caudal appendage of the crotalus, but to rustle with a similar sound when shaken by the wind: Its popular name is "rattlesnake. grass." Why not argue that, through natural selection, the serpent has acquired a tail which, when held erect (as this serpent's tail so often is), shall so resemble the grass-heads among which the reptile freqnently lies in ambush that its prey may see no difference, and so may come unwarned within reach of the fangs? Or, if it is assuming too much to take for granted that the grass form is older than the snake form, so that the lattermust have changed to suit the former, then why cannot we argue plausibly that the plant gradually developed towards its present form because those ancestral plants which more and inore nearly approached this appearance were more and more avoided by the crushing feet and nibbling teeth of animals which feared the rattlesnake, and hence avoided anything that looked or sounded suspiciously like it?

Of course I am not advancing a serious argument in bringing this forward, but it seems to me that it is quite as good and logical as the cicadastory or some other theories which I have lieard of. That natural selection has had something or everything to do with the rattle of the crotalus, I cannot but believe; but I fear we do not yet perceive in what manner.

Althongh, as I say, I cannot adınit that the insect mimicry is worth much consideration, I can see how the noise made by the tail might act as a deadly lure to birds and small mammals by working upon their curiosity - a weakness particularly noticeable in squirrels. The interesting

* The summary of this discussion may be found in The American Naturalist, vi., 32, 260, and vii., 85. The rattles also form the theme of articles in Harper's Magazine, x., 470; in Chamber's's Journal, xlix., 641 (copied into the Eclectic and Every Saturday); in The Lateeside, v., 252 ; and in the Southern Literary Miscellany, xvi., 27. 
record Dr. Mitchell gives of the behavior of the small animals he was constantly placing in the cages of his large colony of rattlesnakes, bears directly upon this point, and has been contirmed by other writers. Nove of them exhibited any terror at the company they found themselves in, after they had recovered from their nervousness at being handled. "The sinaller birds ... soon became amusingly familiar with the snakes, and were seldom molested, even when caged with six or eight large crotali. 'The mice, which were similarly situated, lived on terms of easy intimacy with the snakes, sitting on their heads, moving around their gliding coils; undisturbed and unconscious of danger." The little creatures were eager yet timorous to examine erery part of the folded and strangely clothed occupants of the prison-cage. When visitors as large as dogs-against which, by the way, this snake sliows special antipathy*-tried a close investigation, the serpents themselves became fearful, sounded their rattles, and struck in self-defence.

This innocence of danger on the part of birds, mice, guinea-pigs, etc., wonld go strongly against the position so often assumed, to begin with, that the rattling would be disadvantageous to the snake because it would instantly frighten away the small animals intended as prey; since, so long as the serpent does not chase them, they seem to associate no harm with his face or his music. Why should they? How can they have had any experience of him that would be effective to their minds? A horse or deer is struck, suffers, and recovers, but remembers tenaciously (very likely instructs his young) what it was that inflicted the injury. Never a squirrel or warbler survives to profit by the lesson or tell the tale, and usually there are no witnesses to the deed. The smaller agile serpents would be more likely to inspire general alarm, becanse they are often seen in hot puisuit of prey they do not always catch.

But though it is possible that by playing upon the curiosity, or even by deceiving through mimiery, the crepitating tail might now and then become nseful, I do not think that, as an aid in food-getting, it is ever of more than accidental service. As a matter of sober fact, the rattle is not heard when the crotalus is seeking its prey, which is procured by stealthily crawling upon it, or by lying patient and rigid, ambushed in the accustomed hannts of sinall animals, until chance favors.

* A strange bit of Indian superstition may be mentioned here. Among the northern Californians, according to Bancroft, snakes appear to get most of the blame for sickness. The medicine-men of this race pretend to discover the locality of the reptile-spirit in the body of a suffering patient by barling at it for some time, the idea being to frighten it away as a $\operatorname{dog}$ would a live snake. 
What, then, is the raison d'être of this rattle? It is not itself a weapon, nor has it anything to do with the mechanism or effect of the poisonfangs, for it is not sounded when a stroke is made in a natural and unalarmed way, for the sake of killing food. The composure with which mice and squirrels listen to this strong and characteristic racket argnes this by inference, as showing that they do not connect the sound with any idea of harm. If it is true that the tendency to make rattles in this group of ophidians has been "seized upon by natural selection and made functional," then it seems to me that everything goes to show that this function is not for foraging, but is, first, one of defence through a defiant warning, and, secondly, a means of calling the sexes together, thus ministering to the propagation of the race.

Fear, or the restless desire for companionship, are the only influences that evoke sounds from serpents or any other reptiles. The batrachians may croak and pipe for fun, but the bellowing of the pine-snake, the blowing of the hog-nose, * the hissing of the black and various grass snakes, is only heard when they are calling to the other sex in the pairing season, or when they are attacked. The rattlesnake, however, has no voice, can make none of these sounds with his throat, so that his means of communication and expression are confined to his rattles, and the nore you attack or annoy bim, the louder is his utterance of protest. This is to be seen plainly with fresh captives, full of alarm at confinement and observation.

A strong illustration occurred on one occasion when I was one of

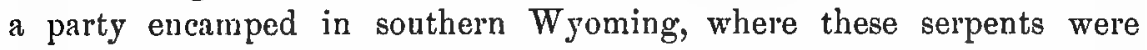
most plentiful among the sage-brush. Going a short distance from my tent one evening, I was suddenly moved to make a most active leap by the baleful whir of a rattler just beside me. Regaining my composure, and returning to the cliarge with $m y$ revolver in iny hand, I found that his snakeship had betaken himself to a gopher-hole, where I could hear a lulled crepitation. Stamping above the burrow caused the tune to assume a crescendo instantly, whereupon I sent down a long .032 to further wake up the musician. His rattling now was loud and rapid. I fired a second time, and the song accelerated until all rattling blended into a steady buzz. If I had hit him I hadn't killed him, it was evident, so a third ball and stream of fire was shot down the hole. Out of the report

* An entertaining and suggestive account of the way this harmless snake behaves when threatened with harm appears in Science, vol. iii., p. 254. Instead of fleeing, it flattens its head, hisses, springs menacingly, and snaps fiercely; its tail vibrates rapidly, and should there be any dead leaves against which it may strike, the noise will be greatly similar to that of the rattlesnake, which it seems really to imitate as a deliberate measure of safety. 
came a shrill, high-pitched hnmming, which told of swifter vibration than even the buzzing had showed. Surely a snake was never more excited. since the world began! But speedily this became feeble, intermittent, and soon ceased altogether, so that I concluded my shots had finally reached him with fatal effect.

That the rattling of the crotali answers the purpose of a call, we know from the fact, recorded in many places, that other rattlesnakes quickly respond and hasten towards the one ringing his alarum. Moreover, in the latter part of the summer the snakes sometimes make the sound loudly and long, when they have no apparent reason to be alarmed, but, by the argument from analogy, can reasonably be supposed to be calling the opposite sex. That the rattling of one serpent in captivity has an immediate effect upon other crotali within hearing is constantly observed; and in the cases where the young have been seen to run into the mouth of an old one for protection, they appear to have been summoned and informed of their danger by this signal. The instant the snake suspects danger it throws itself into the coil of vantage and sounds its long roll, varying the swiftness of the vibration and the consequent londness of its note as its apprehensions increase or diminish. The noise itself may not be instinctively fear-inspiring, nor, perhaps, is the growling of a lion, but in each.case experience has tanght men and the large qnadrupeds that that growl and this rattle mean not only a willingness to defend, but the certain ability to do deadly harm. This menacing message, clicked from the vibrating tail, has caused many a man to turn back and give the snake a chance to escape, and at the same time it has been a warning to all other crotali within hearing to prepare for battle or seek safety in flight.

Thongh man and his hogs* are now the worst enemies of the rattlesnake, he has various others, principally colubrine serpents, who delight in chasing and killing him. Of these the chief examples are the blacksnake and blue racer (or "pilot") in the North, several western species, and the king-snake of the Sonth. Leaping upon the fleeing and demoralized rattler, they seize his neck in their teeth, and quick as thought wrap their folds about him with crushing power.

The king-snake enjoys protection at the Sonth, because of this championship, against the noxious rattler, in which, however, he is by no

* It is generally believed that the hog is safe from the poison of the rattlesnake. This is so only because his thick skin and layers of fat prevent the venom in the majority of cases from reaching his circulation. Swine are fond of flesh, and greedily devour the snakes they are so quick to kill by stamping. 
-means alone. Pennant is anthority for the statement, which I have no other proof of, that the land-tortoise "is an utter enemy to the rattlesnake; will seize it below the neck, and by drawing its own head into its shell becomes invulnerable. The snake entwines about the tortoise, but is soon destroyed and left on the ground." There is a queer belief among some of the negroes, by-the-way, that if a snake is killed by the rattler, the blacksnake rubs against the body and brings it to life; hence that species is called the "doctor-snake."

However the crotalus may manœuvre to get his victims within reach, once there he has a weapon on whose certainty he has no fear of relying -the poisoned fangs in his opened jaws. The anatomy of the head and poison apparatns, and researches upon the venom of the rattlesnake, formed the subject of a long series of experiments, some years ago, by Dr. S. Weir Mitchell, of Philadelphia, which resulted in the publication of an elaborate memoir in the twelfth volume of the "Sinithsonian's Contributions to

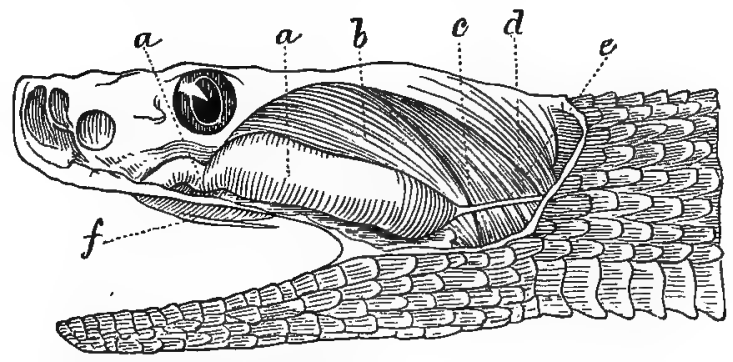

CRANIUM OF CROTALUS, WITH MUSCLES CONCERNED IN THE VENOM STROKE.

$a, a$, venom gland; $b$, anterior temporal muscle ; $c$, posterior temporal muscle ; $\vec{d}$, digastricus; $e$, posterior ligament of the sheath of the gland; $f$, vagina dentis, the fang slightly raised. (Mitchell.)

Knowledge." To this memoil further researches have recently been added.

In repose and unmolested the snake sometimes lies at full length, sometimes twisted up; in confinement, where several are in the same cage, it is very fond of entangling itself with its fellows. The instant it

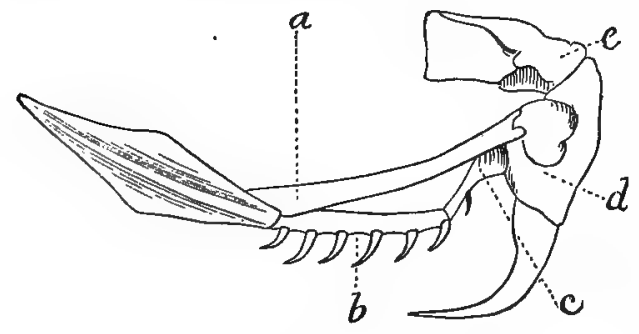

BONES OF THE UPPER JAW.

$a$, external pterygoid bone; $b$, internal pterygoid; $c$, palatal; $d$, superior maxillary; $e$, lachrymal. (Hitchell.) is alarmed, however, it throws its body into the familiar coil, its tail protruding enough to adınit of its vibration, the forward part of the body lying in short curves across the mass of coils, and the head beld three or four inches erect. In this position a sudden and violent contraction of the muscles upon the convexity of the curves 
near the neck dart the head forward, and are accompanied by a wonderful series of muscular operations resulting in the poisoned stroke. The mechanism of this action, the poison and its nature, and apparatus for

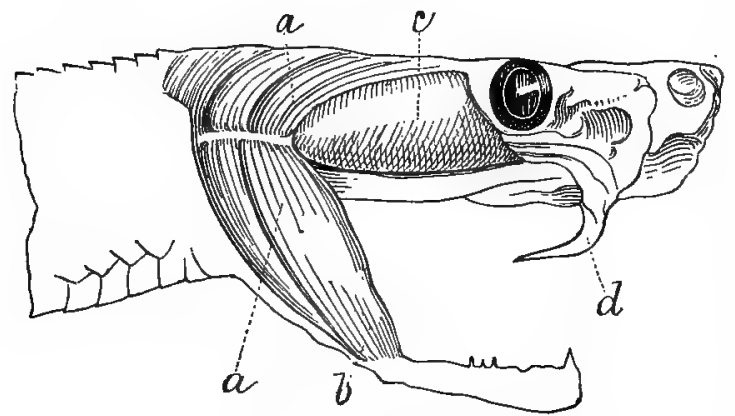

RELATION OF TEMPORAL MUSCLES TO THE GLAND.

$a, a$, anteriol tempornl muscle ; $b$, its insertion in the lower jaw ; $c$, vellom gland; $d$, the fung, hulf elected. (Mitchell.) its discharge, are unatters upon which I need not touch here. Dr. Mitchell's paper, alluded to on page 103, discusses them thoronghly; and the accompanying illustrations, redrawn from his monograph, make plain the anatomy of the complicated poison apparatus. Similarly the interesting pathological effects of the renom, which is a septic or putrefacient poison of astounding energy, may be omitted.

When one recalls how many of these venomons serpents have been secured alive, the question of how they are caught becomes one of some interest. The Indian method was to put a long forked stick over their necks, and then noose them with a bit of thong. This is the ordinary fashion yet, and quite safe if you are careful. The cirenmstance that a big one once crawled out from under my blankets in a Rocky Monntain camping-place, when they were pulled aside in the morning, gave me an opportunity to see a man seize a rattler by the tail and dislocate its head by a strong snap before the reptile had time to coil. Simpson relates that his taxidermist canght one by the back of the neck in Utah; and that coolest of men, Charles Waterton, conld do this every time, as he showed in England to prove that he had not been romancing when he described his encounter's with deadly serpents in South America. A box of twenty-seven living crotali had been sent to Leeds, and Waterton invited a large party of scientific friends to see liin move them one by one to a glass case and back again. This he did (after cantioning the visitors neither to move nor speak) by silently, slowly, and quietly slipping his hand along the back of each snake till he conld grasp him gently behind the head and softly lift him into the other box. He trusted for his immunity to the slnggish nature of the creatures, and to the fact that he did nothing to aronse their fears.

Once in West Virginia I had brought to me a good-sized rattler that 
a woman had caught when berrying in the monntains. Two children were with her, and they suddenly disturbed four of the snakes. Remembering my advertisement for living reptiles, the family applied themselves to capturing the whole fonr, but only succeeded in getting this one unmaimed by pinning it to the ground with a forked stick. Then the problem arose, how to fasten and carry the creature. Having a long piece of twine and a tin collender with her, the woman made a slip-noose of the string and passed it up through one of the holes in the bottom of the vessel. Then, by the aid of a switch, the noose was looped over the triangular head of the captive, and the collender (inverted) let fall upon him as the boy removed his prong. Mr. Snake at once coiled up in the round tin dish and began singing in his highest key, but the check-string through the bottom held his head down, and thins ignominiously he was bronght to my house. "I've packed the ornery critter a heap of a distance, 'n' I reckin I onghter' have six bits," the woman said, and I cheerfully paid it.

It has already been asserted that the poisonons quality of the snake resides wholly in the fluid of the venom-gland. A wound from the other teeth does no harm, and the Indians and some rural doctors of old days used the shar'p little points, set comb-like in a split reed, as convenient and effective scarifier's when blood was to be let for medicinal or superstitious ends. No fang conld ever be nsed safely for that purpose. The flesh, too, which is white and flaky, like that of frogs or the breast of birds, has often served as food, its forming a part of the aboriginal fare being noticed by the earliest writers. Josselyn tells us that the New England Indians, "when weary with travelling," will take up rattlesnakes with their bare hands, "laying hold with one hand behind theil head, with the other taking hold of their tail, and with their teeth tear off the skin of their backs, and feed upon them alive; which, they say, refresheth them." It is possible in this practice to see the doctrine of transmutation of qualities (namely, that the human spirit will become imbued with the characteristics of what the body is fed upon) which led to cannibalism, and operates throughont all the savage theory of life; but Charlevoix has no mysterious benefit in view, beyond the satisfaction of hunger, when he says the Canadian Indians " chace it, and tind its Flesh very good. I have even heard some Frenchmen, who had tasted it, say that it was not bad eating; but they were travellers, and such People think everything good, because they are often hungry. But this [is] at least certain, that it does no harm to those that eat it."

The worthy man need not have been so incredulons and sarcastic. 
When Bartram was in Florida he was asked to sit down to a feast with the chief military man of the region, where the central dish was the carcass of a great diamond rattlesnake the naturalist had killed that morning. Long ("Travels of an Indian Interpreter") confessed that the flesh was "delicions," and that he had frequently eaten it "with great goût." To the darkies of the cotton states the rattler is always edible. Only a year ago I was told by a gentleman in Alabama of two servants whom he canght bitterly disputing over a carcass of this reptile.

"Why, Jake," said he to one of the negroes, "what's the use of a quarrel? You couldn't get more than fifty cents for it any way."

"Don' want 's hide," was Jake's reply. "Jim can hab dat. I wants his flesh to eat!"

Instances of this might be multiplied, but I leave them to say something about the place of the rattlesnake in popnlar pharmacy. Quoting Loskiel : "The flesh of the rattlesnake, dried and boiled" to a broth, is said to be more nourishing than that of the viper, and of service in consumptions. Their gall is likewise used as a medicine... The skin usually shed by rattlesnakes is dried and pounded fine by the Indians, who use it internally for many purposes." John Carver records that the Chippeways extracted splinters with the cast skin. "It is amazing," he exclaims, " to see the sudden efficacy of this application, notwithstanding there does not appear to be the least moisture remaining in it." Brickell, in his quaint "Natural History of North Carolina," also refer's to this point. "These Snakes," he says, "cast their Skins every Year, and commonly remain near the Place where the old Skin lies. These cast Skins are frequently pulverized, and given with good success in Fevers; so is the Gall mixed with Clay, nade up in Pills, and given in Pestilential Fevers and the Small Pox, for which it is accounted a noble Remedy and a great Arcanum, which only some few pretend to know, and to have had the first Knowledge and Experience of for many Years; so are the Rattles good to expedite the Birth, and no donbt but it has all those excellent Virtues that the Viper is endued with." We learn from Thomas Campanius that a similar notion prevailed among the Swedes at the mouth of the Delaware.

The use of rattles in parturition or for abortion seems to have been very wide-spread among our aborigines, extending into Mexico and far northward. A Dakota medicine-man explained it by saying that the child heard the rattle, and, supposing the snake was coming, made haste to get ont of its way-a remarkable example of hereditary instinct! This is nonsense, of conrse. The real explanation of the custom belongs to the 
category of religious superstition, as does a large part of savage medical practice.

In casting its skin every spring, the serpent seems to renew its life-a marvellous and suggestive thing. No wonder the childlike Indians saw in this something supernatural, and stored the cast-off slins in the medicine-bag, believing them endowed with fetishistic and remedial virtues. "Itself thus immortal, they thonght it could impart vitality to them. So, when the mother was travailing in sore pain, and the danger neared that the child would be born silent, the attending women hastened to catch some serpent and give her its blood to drink." Among the red men of the New World, as with ancient Esculapians in the Old, it stands as the sign of the remedial art.

Europeans were not slow in accepting these Indian ideas of medicine, and have been still slower in giving them up.

I have heard within very modern days of rattlesnake oil prescribed as a febrifuge and for divers other ailments, while its value in rheumatism is regarded by few persons with doubt. The demand for it is shown by the fact that the serpents are often hunted systematically in order that quantities of their oil may be obtained. That was the object the men of Warren County, New York, had in killing the eleven hundred snakes of which De Kay gives an account. Every summer, to this day, citizens of Portland, Connecticut, go out to the Rattlesnake Ledges and catch the reptiles with gaff-hooks, the local druggists paying them four dollars an ounce for the oil, which finds ready sale. A prominent physician in Washington told me of a case within his knowledge where a man suffering from an ulcer took a rattlesnake into his bed with the vague idea of somehow extracting the virulence of the sore. In some rural districts men wear the rattles in their hats as a remedy for headache; and I knew of a case in the Watauga Mountains of North Carolina where a man who was far gone with consumption hung the body of a rattlesnake to dry and smoke in his chimney, where he might nibble at it and get well. His faith was weak, and he did not take the medicine; but a sickly boy began to pull the flesh from the skeleton, and grew fat and sturdy before he had finished it. In the Eastern States it used to be considered a "specific" in cases of epilepsy-a disease with which more witchcraft and superstition is mixed up than almost any other on the catalogue.

No red-skinned sorcerel's medicine-bag is complete without some fragment of this striking and half sacred reptile in it; while negroes at the South, who are sufficiently superstitious to wear charm-bags, regard the curions rattles as among the most precious of their amulets. 
In view of these facts it is not strange that parts of the serpent shonld be regarded of value as a specific against the poison of its own bite. Similia similibus curantur-hair of the dog cures the bite-is a precious doctrine in the old pharmacopoia, and one handed down from saragery, I fancy. Thus, according to the Spanish historians, the Opatas, a Mexican race, took this plan when one of their people was bitten: Seizing the reptile's head between two sticks, the unfortunate Indian would stretch the creature out and bite it along the body; wherempon, as in Goldsmith's poem of the hero of Islington, the man recovers of the bite, the snake it is that dies. New England tribes prescribed a powder from the serpent's cast skin, the Delawares and Chippeways rubbed its fat into the wound, and the Potawatamies kept the fang about them as a sure charm against the bite.

As this chapter would be made far too long by discussing the effects of crotalns venom upon the vital system, so it must omit the matter of antidotes further than to allude to the fact that many plants have been regarded as efficacious, the reason, apparently, being that something about them bore a fancied resemblance to a serpent (e.g., the root of the blacksnake wood), which convinced the credulons old herbalists that the plant was manifestly designed by Providence for this purpose. Thus Du Pratz, in his "History of Louisiana" (vol. ii, p. 43), describes the curative power of the "rattlesnake herb"-apparently the same from which I drew an "argument" in earlier" pages-saying of it, that "when the head is ripe it will, when shaken, give the same sound as the tail of a rattlesnake, which seems to indicate the property of the plant."

In the far West various local plants possess this beneficent distinction, and to some of them deers and bisons are said to resort for healing; but I disbelieve it, and notice that the Indians hold the snake in the greatest terror despite the herbs. The Nishinams of California, indeed, seek supernatural protection against bites during the ensuing season by a sportive ceremony that takes place every spring. Arnong the Pomos, another once powerful tribe of northern California, an annual ceremony of the direst import was gone through with by the men on purpose to frighten and properly subjugate their women. The personation of devils and their doings was enacted in every way, and the whole affair wound up by a grand oration from the venerable peace-chief-a sort of high-priest of the tribe-in which he brandished full in the faces of the squaws a rattlesnake held in his hand, threatening supernatural ills if they failed in chastity and obedience, until many of them fell in a swoon of terror.

This powerful effect is obtained through their religious notion of 
the transmigration of souls-a belief almost universal among our native Americans. Good Indians go at once to happiness, but the souls of bad Indians take up their abode in various animals of evil repute. In this baleful list snakes take a prominent place, and become "an object of superstitious belief and unfeigned terror, inasmuch as they consider them to be vivified by the souls of the impions dead, despatched as special emissaries of the devil to work them evil." With the Apaches, for example, this is a very distinct doctrine. To the Pomo squaw, therefore, the rattlesnake brandished before her eyes, under the hot denunciations of the orator, was not simply a suggestion of eternal pnnishment, like the smell of brimstone to a Puritan, but a visible incarnation of one of the foremost of those malevolent forces which the Indian supposed filled the world, existing only for his annoyance, and turning his religion into demonology.

This doctrine of "animism," as it has been called, existed to a greater or less degree among all the aborigines, conferring upon every object in nature, and especially upon animals, spiritual qualities, or a shade, through which it was able to exert an influence upon humanity. The more powerful to inflict harm anything showed itself to be, the more awe and devotion it required. Thus the dangerous currents of falls and whirlpools are supplicated and offered sacrifices, to propitiate the resident spirit animating the disturbed waters and contending with the canoe.

When an Ojibway warrior prepared for battle, the rattlesnake was a part of lis accoutrements. "It is always observable," says Peter Joues, "that the Indians take ont the bag which contains the poison of this vehomous reptile, and carry it alive in their medicine-box when they go to war.". Another custom was to wrap about their waists a black watersnake-alive at first, but retained after its slow death until the end of the foray.

Thus among animals the whole class of serpents came to take high rank in the long catalogne of spirits, and the rattlesnake, with his satanic face and terrible fangs, rose above all into a superior and distinct deity, which was held by some groups of Indian tribes in the greatest fear and veneration - terms nearly or quite synonymous in aboriginal theology. This was especially noticeable among that race whose home was in the neighborhood of the Great Lakes. In the Ojibway country a rattlesnake was never killed except under some stress of circumstances, when "it was accompanied by forms and ceremonies, and a sacrifice was left near the carcass." Some Atlantic coast tribes made it a water-god-an easy suggestion from the siunous, serpent-like course of a rirer. "Kennebec, 
a stream in Maine, in the Algonkin means suake, and Antietam, the creek in Maryland of tragic celebrity, in an Iroquois dialect has the same significance." Of others it was the tribal token, an instance being the Snakes of Idaho, a division of the Shoshonee family.

The wriggling attitudes of the snake helped the strong suggestiveness of its swiftly glancing forked tongue to erect it into an earthly symbol of the zigzag lightning; and by the Shawnees thunder was described as the hissing of a great snake. Almost all the tribes had a mythical and gigantic thunder-bird (birds and serpents are closely related in the naturemyths of all nations); and in most of the stories about it a serpent takes an accessary part, as beld in its claws and shown in the lightning; as robbing its nest; as dwelling in volcanoes and other inaccessible homes of the thunder-bird; and as otherwise performing mysterious and supernatural functions. This appears plainly, not only in their myths but in the pictographs, and accords well with the fact generally accepted by comparative mythologists, that the meaning paramount to all others in the serpent emblems of European mythology is the lightning.

In that admirable book, "Myths of the New World," Dr. Daniel G. Brinton has written two or three pages covering this point so well that I cannot refrain from quoting a part of it, though at some length:

"In snake-charming, as a proof of proticiency in magic, and in the symbol of the lightning, which brings both fire and water, which in its might controls victory in war, and in its frequency plenteous crops at lome, lies the secret of the serpent symbol. As the 'war-physic' among the tribes of the United States was a fragment of a serpent, and as thus signifying his incomparable skill in wal, the Iroquois represent their mythical king Atatarho clothed in nothing but blacksnakes... so, by a precisely similar mental process, the myth of the Nalinas assigns as a mother to their war-god Huitzilopochtli, Coatlicue, the robe of serponts.... Her son's image was surrounded by serpents, his sceptre was in the shape of one, his drum was of serpent's skin, and his statue rested on four vermiform caryatides.

"As the symbol of the fertilizing showers, the god of lightning was the god of fruitfulness.* Born in the atmospheric waters, it was an appropriate attribute of the ruler of the winds. ... Quetzalcoatl, called also Yolcuat, the rattlesnake, was no less intimately associated with serpents

* This gives a hint of the philosophy inspiring the supposed efficacy of rattlesnake amulets, ointments, and potions, savage and half-civilized, in cases of parturition, which are referred to on pages 98 and 106.-E. I. 
than with birds. The entrance to his temple at Mexico represented the jaws of one of these reptiles, and he finally disappeared in the province of Coatzacoalco, the hiding-place of the serpent, sailing towards the east in a bark of serpents' skins. All this refers to his power over the lightning serpent.

"He was also said to be the god of riches, and the patron, consequently, of merchants, for with the summer lightning come the harvest and the ripening fruits, come riches and traffic. Moreover, " the golden color of the liquid fire,' as Lucretius expresses it, naturally led, where this metal. was known, to its being deemed the product of the lightning. Thus originated many of those tales of a dragon who watches a treasure in the. earth, and of a serpent who is the dispenser of riches such as were found among the Greeks and ancient Germans. So it was in Peru, where the God of Riches was worshipped under the image of a rattlesnake, horned and hairy, with a tail of gold. It was said to have descended from the heavens in the sight of all the people, and to have been seen by the whole army of the Inca. ...

"Because the rattlesnake, the lightning serpent, is thus connected with the food of man, and itself seerrs never to die, but annually to renew: its youth, the Algonkins called it 'grandfather,' and 'King of Snakes.' They feared to injure it; they believed it could grant prosperous breezes, or raise disastrous tempests; crowned with the lunar crescent* it was the constant symbol of life in their picture-writing; and in the meda signs the mythical grandmother of mankind, Me-suck-kum-me-go-kwa, was indifferently represented by an old woman or a serpent. For like reasons Cihuacoatl, the Serpent Woman, in the myths of the Nahuas, was also called Tonantzin, our mother.

"The prominence of the rattlesnake as a pecnliarly American symbol, indicated by these references, has received most ingenions and abundant illustration from indigenous art through the studies of Dr. Harrison Allen. Commencing with the suggestive remark that the serpent is the 'only animal facile to the purposes of the pattern-maker,' he has traced its variant forms in the picture-writing, the phonetic signs, and the architectural ornaments of the red race, and shown the remarkable preference they. liad for the line representing the profile of the head of the rattlesnake, to the radical of which he has applied the term 'the Crotalean curve.'

"The serpent symbol in Anerica has, however, met with frequent

* In a Nishinam (California) myth, according to Powers, the moon created the rattlesnake. - E. I. 
misinterpretation. It had such an ominous significance in Christian art, and one which chimed so well with the favorite proverb of the early missionaries-'the gods of the heathen are devils'-that wherever they saw a carving or picture of a serpent, they at once recognized the sign-manual of the Pince of Darkness, and inscribed the fact in their note-books as proof positive of their cherished theory. After going over the whole ground, I am convinced that none of the tribes of the red race attached to this symbol any ethical significance whatever, and that as employed to express atmospleric phenomena and the recognition of divinity in natnral occurrences, it far more frequently typified what was favorable and agreeable than the reverse."

I think investigation would show, in respect to the American rattlesnake, that the veneration of it was strongest and most grossly manifested in those regions where this serpent was less often seen, and hence more invested witl mystery than in an open country like the Texas plains or the Utah basin, where it was far more plentiful and seen nearly every day. It is noteworthy, for example, in the legends of the Kái-vavvits, living at the head of the cañons of the Rio Colorado, where snakes are almost as plentiful as sage-brush, that the rattler figures as one of the first and most powerful of the demigods from whom that race count their descent; and he is not regarded with the superstitious terror seen on Lake Superior and elsewhere, but as a master of cunning and the art of success.

He does many. wonderful things in these myths by virtue of his power of rendering himself invisible. Thus, when the migrating host of one of the stories was famishing, and an antelope was seen, Shinaú-av, the Coyote-a greater man in popular estimation than To-gó-av, the Rattlesnake-proposed at once to go and kill it; "but To-gó-av demurred, and said, 'It were better that I should go, for he will see yon and run away ... but I can kill him, for I can go where he is, and he cannot see me." " It is perfectly natural that the secretive habits and the almost invisible, imitative luve of this rock-hiding reptile should find such expression in a myth of which his doings form a part. 


\section{$\mathrm{X}$. \\ "MINE OYSTER'S" BATTLE OF LIFE.}

THE oyster is a creature whose battles are wholly those of defence. 1 He maintains a strong inertia, closes the ports of his fortress, makes no sallies, and defies the enemy to harm him by any means short of demolishing his walls. That achieved, he has no further means of resistance and quietly submits to his fate.

To the enjoyment in tronblous times of this otium cum dignitate he is entitled by a venturous youth passed amid the dangers of the deep, where foes without number lie in wait for tender offspring. To begin $a b$ ovo, the eggs of American oysters are not held under cover of the parent shells until they hatch, as is the case with the European oyster, but are discharged by the mother, unfertilized, into the water, where, first of all, they must await the chance of accidental impregnation; this, moreover, must come within a very short time if it is to come at all.

Enormous is the multitnde of these eggs. The eminent biologist, Dr. W. K. Brooks, estimates that ten millions is the average yield from each individual, and that as many as sixty millions may be laid by a single motheroyster. This prodigious supply is needed to counteract the risks they are destined to run.

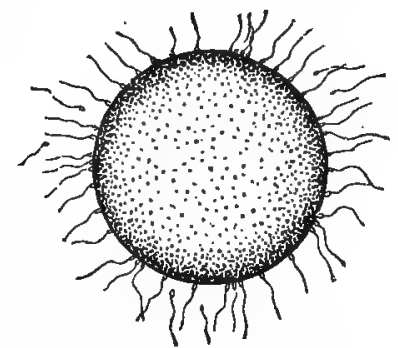

OYSTER'S EGG, IMMEDiaTELY AFTER FERTILIZATION. Says Professor Ryder:

"So numerons and effective are the adverse conditions which surronnd the millions of eggs matured by a single female that only the most trifling fraction ever develop. The egg of the oyster being exceedingly small, and heavier than water, immediately falls to the bottom upon being set free by the parent. Shonld the bottom be oozy or composed of sediment its chances of development are meagre indeed. Irrecoverably buried, the eggs do not, in all probability, have the chance to begin to develop at all." 
Nevertheless, a few escape and hatch out. Thereupon begins a series of trials for the life of each embryo, so severe that it has scarcely one clance in a million of surviving.

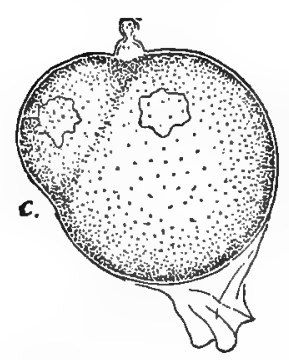

EGG THREE HOURS AFTER FERTILIZATION.

These embryos, when first hatched, rise to the surface of the water and swim there a few hours, after which they begin to sink; and two or three days may elapse before they are prepared to become stationary. This is the period of their greatest peril. Invisible motes, dancing a whirligig career just beneath the surface, the gay young oysters are endangered by the open jaws of every marine creatnie larger than themselves, and thousands may sometimes perish in a single mouthful.

They run a constant risk from the weather,

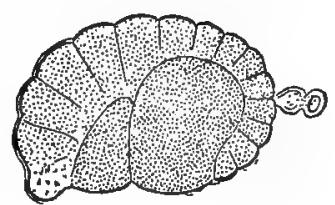

EGG AT A LATER STAGE. also. During his study of them on the Chesapeake, Dr. Brooks found that any sudden cold wind, or a fall in the temperature, such as occurred

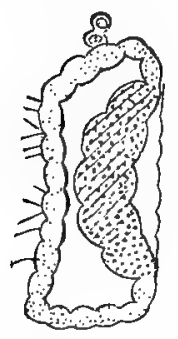

EGG IN ITS FINAL STAGE. several times during his experiments (though made in midsummer), would kill every embryo in his care. How widespread must be the destruction from such canses in the open estuaries! Of the ten million eggs shed by one parent, perhaps half a dozen may survive to be graduated from this play-day into the settling-down stage which begins the third period of an oyster's life. How inscrutable wonld be this fearful waste of potential life if we were compelled to think of it as foreordered by the settled determination of a Creator's fiat-a scheme of reproduction unswayed and unswerv. able by any altering circumstances, subsequent to its establishment in this world of incessant change!

Up to this point Nature has left the joung oyster unshielded, so far as can be seen. There is no protection for him whatever against the liability to be destroyed-if, perchance, he ever succeeds in getting born !not only through the voracity of a host. of marine animals, from sponges np to the "leviathan," but also by comparatively slight changes in the air or water. We can fancy him quoting the melancholy old soliloqny,

\footnotetext{
"If so soon I'm to be done for,

I wonder why I was begun for!"
}

Nature has seemed to say, Let them go it! I will provide so many that 
if only one in a million lives throngh, it will be enough to preserve its race from extinction. Thus, as it were, young oysters uncountable are cast into the ocean to be scrambled for by a host of fishes and small fry.

But when the minority that have escaped destruction, between the Scylla of ill-tempered water and the Charybdis of hungry mouths, are ready to affix themselres to some solid basis, where

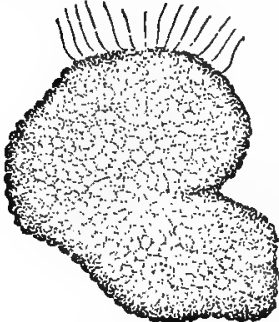

FIRST APPEARANCE OF THE EMBRYO. they may remain stationary throngh life, then Nature begins to help them. Heretofore she has trusted in luck and the power of numbers. Now that the ranks are perilously thinned, she gives the remnant of oyster-waifs that persists the rudiments of what will become an armor for their protection, perceivable as yet only by the trained eye of the microscopist, for a hundred of these embryos, side by side, would measure no more than an inch.

The hour's of the infant oyster's swimming are now over. The embryo sinks slowly to the bottom. If it alights upon ooze or a slimy surface it smothers, or dies in the vain attempt to get foothold. If, luckily, it strikes the cleaner surface of an old reef of dead shells, a rock, a pebble, or lately subinerged stick, then the pin-head of jelly attaches itself to a spot whence it will rove no more.

Even before this time of becoming stationary, microscopists can detect in the simple organization of the little creature the rudiments of the armol of defence. These consist of a crust of two pieces lying on each side of the body, and joined over the vitals by a hinge which permits a slight movement; from them will develop the futnre "shells." Small as it is, now that it has fixed itself for all time, the little oyster must begin to breathe, as its parents did before it. "Like

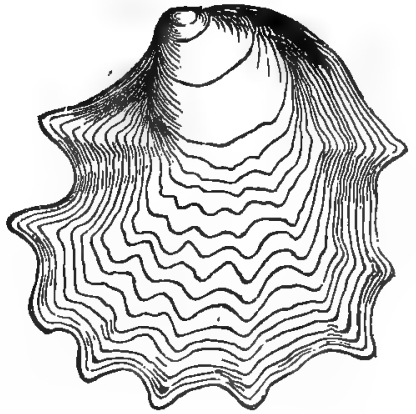

AN OYSTER ONE YEAR OLD, SHOWIFG EMBRYONIC SHELL AT THE APEX, AND UINES OF SUBSEQUENT ADDITIONS. them its gills soon grow as little filaments covered with cilia, which cause a tiny current of water to pass in and ont of the shell. The reader's imagination may be here allower to estimate the feeble strength of that little current which is of such vital importance to the tiny oyster, and the ease with which it may be stopped by a very slight accumulation of dirt."

This liability to smothering is the first of his obstacles. Escaping it. he increases in size rapidly, but his ranks are thinned by crabs and vari- 
ous small mollusks. Become large enongh for us to find him without the help of lenses, he seems merely a whitish, horny flake on the surface of his support, like the nail on the little tinger of a babe. From now until the shells get to be the size of a nickel coin, and begin to look rough, the oysterman calls him a "blister"-an expressive term.

If the affixture of the infant oyster is made in the midst of a cluster of others, his only opportunity for growth is straight upward by additions around the edges, but most extensively at the "nib," or point of the shell opposite the hinge, while the older part continually hardens and thickens until the maximum is reached. In this situation both halres of the shell will increase at about an equal rate and become very similar, as one sees them in those long, narrow forms of wild oysters from the surface of reefs, which are termed by the fishermen "strap" or "stick-up," or (in the South) "coon" oysters.

When, on the other hand, the bivalve attaches limself (accidentally, of course, for, so far as we can see, this is a matter in which the oyster exercises no choice) where he is not in close contact with others, and has room to grow in any and all directions, then the shells become more and more unequal. That one underneath, as the creature lies on its side, is soon seen to be getting greatly the advantage in size and strength. Consequently, by the time adult proportions are reached, the lower valve often broadly overlaps the upper valve, which shuts down into it as completely as the lesser mandible of a duck tits into the concavity of the more capacious opposite half of the beak. When an oyster is opened to be eaten raw, it is this "deep" lower shell that serves as a convenient dish upon which to offer it, while the thinner upper one is thrown away.

These heary shells, it is needless to point out, are a provision for the animal's defence. Nature can no longer trust to numbers or minuteness or invisibility to save her oysters. If she cares to preserve any as breeders of future generations, she must take better care of them than heretofore. She does not require them to go abroad in pursuit of food, but undertakes, by a simple apparatus for inducing currents of water, that it shall be bronght to them in a never-ceasing supply, withont other exertion on their part than to open their months and sleepily let the nutritious streams course their way into and out of the digestive cavity of the body, where an automatic action of the stomach abstracts the food and rejects the superfluous water.

With this fixed location, and passive method of subsistence, oysters manifestly would have no occasion or opportunity to make use of weapons either for active offence or for l'esistance. Nevertheless, Nature does 
not clioose to leave them exposed to their foes in a fleshy mass, protected, if at all, only by stinging or bitter qualities which night make them noxions to the taste, such as are possessed by the unarmed hydroids and actinians. The only alternative, apparently, is to give them a stout armor. This is the service which the heavy shells perform in oyster-life. That it is only partly effectual, a short acquaintance with the subject suffices to show; a fact that seems to me to argue strongly against the validity of the view-one, I am glad to say, less prevalent now than formerly - that all details of this kind were arranged fixedly from the start, and must necessarily be considered the most perfect that could be devised.

I have said that when the oyster attaches itself by the rounded surface of one valve and grows in a sidewise position, as it is very likely to do in regions where the bottom is disturbed by constant raking, the lower valve soon becomes far stonter and broader than the upper; but at the same time the general form is more symmetrical, rounded, and less inclined to show a positive twist with advancing age than is observable where oyster's grow long and thin in the midst of dense clusters. Many foreign relatives of this mollusk are far more irregular in form than ours.

Oysters everywhere lie upon the left side; a case where the right side is underneath is very rare indeed. Why this is so it is perhaps impossible to say with certainty. Probably it is a manifestation of a tendency observed throughout the whole branch of mollusks, where the coiled (univalve) shells all twist from right to left, but where individual exceptions occur here and there, amounting in one case, among the fresh-water physas of our brooks, to the reversal of the custom in a whole genusone, by-the-way, that is marked by extreme irregularity and variation in form among its wide-spread members.

It is this tendency, however it may have originated, to grow on one side to the prejudice of the other, which seems to have produced coiled shells in the great variety of shapes we see; and naturalists believe that they have all come from ancestral bivalved mollusks through a process of natural selection acting primarily upon this supreme tendency. The operculum, or little horny plate attached to the "foot" of a large number of mollusks, by which they stop up the circular aperture of their shells when they retire within them, is considered the remnant (modified for a new utility) of the aboriginal left valve, because the lines of its accretion show that in its growth it followed the same principle of the coil. In some families, as the Limneidce, it has disappeared altogether; but I think that in nearly or quite every case where an operculum is no longer to be found, the animal is minute, and the whole shell has become so thin and 
weak that it no longer affords any real protection against the natural enemies of that species, which are accustomed to devour the animal, shell and all, when they attack it-so that they would nowise be deterred by a thicker shell or the presence of an operculum.

In the same way an operculum would be of no service to such clinging forms of mollusks as the limpets or the abalone (Haliotis); yet, if an abalone or a slipper limpet-" deckhead," as the fishermen call it---be examined, the coiling will be plainly seen.

Protected by its shell, and anchored immovably, the adult oyster sets at defiance the great majority of enemies which it would have good reason to fear were it naked. Its egg-stage and embryonic career were beset with perils which it had no means to guard against, and escaped wholly by chance. During its young life it was at risk of being eaten by a large number of creeping things and swimming things, against whose predatory teeth its thin new tests were an insufficient safeguard. But now, in adnlt age, with feet well planted, muscles strong to hold its doors closed against intrusion, and a triple-plated, rongh-coated shield of limestone over its head, the foes able to prevail against it are reduced from a whole sea full to a small catalogue, the principal members of which the reader will find described in ensuing chapter's.

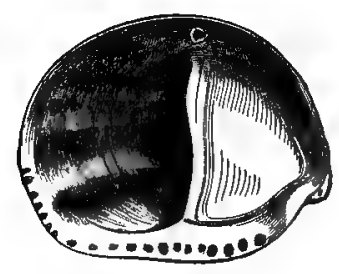




\section{XI,}

SEA-STARS AND THEIR MISCHIEF.

THE most important enemy to the oyster, at any rate in northerly 1 waters, is the tribe of star-fishes - a group of animals known to everybody who goes to the sea-shore, and interesting in many more ways than simply as a pest to the oyster planter.

The star-fish passes under varions names among the shore-folk. In England he is known as the "cross-fish," "sun-star," and "sea-star." In this country the name most often heard is "five-fingers," north of Cape Cod, and southward of there "star-fish," "sea-star," or simply "star," to which it is abbreviated in the vicinity of New York. His family affinities are with the Echinoderms_-"spiny-skins."

None of these names, however, distingnish between the various species, except in the case of the "basket-fish" of Massachusetts Bay, which is sufficiently different from the ordinary fire-finger to attract everybody's. attention; and the smaller varieties are often mistaken for the young of a larger sort.

The common name of the animal well describes its general form. "As there are stars in the sky, so are there stars in the sea," remarked old John Henry Link, a century and more ago. From a central disk of small dimensions radiate five pointed arms, composed of a tough substance unlike anything else that I remember anywhere in the animal kingdom. "When it is warm in one's land," wrote Josselyn, that quaintest of America's advertiser's, in his "New England's Rarities," "you may perceive a stiff motion, turning down one point and thrusting up another." This was all right, but he adopted an error when he added, "It is taken to be poy. sonous."

Examining the star-fish more closely, you perceive that it has an upper and a lower side, essentially different. The upper side, or back, presents a rough surface of a greenish, hrownish, or reddish-green lue, which, when it is dried, turns to a yellowish-brown. This is the leathery nembrane covering the skeleton of the animal, which consists of small lime- 
stone plates united together at their edges by a sort of cartilage, so that they can move in a slight degree; together they form the framework, and act as a chain-armor to encircle and protect all the soft parts within. Underneath, on the lower side of the star-fish, this framework terminates in two series of larger plates, which are braced against one another like rafters, and sustain the whole structure by a sort of arch. This armor is sufficiently flexible to allow the star-fish to bend himself clumsily over or around anything he is likely to wish to climb upon or grasp.

Seattered everywhere upon the upper side are a large number of blunt, short spines, which seem to have no special arrangement, and are longest and thickest at the edges of the rays, and upon the plates bordering the lower side of each ray. Each one of these spines swells at its base, where are fixed in a wreath several curions little appendages called pedicellarice, whose odd forms and movements can only be understood underneath a powerful microscope, on account of their diminutive size.

Each of these consists of a little pedicel, bearing aloft a pair of disproportionately large toothed jau's. The whole affair looks like the claw of a miniatmre lobster, and waves about in a very threatening manner. Now and then it happens that some little particle of food or sea-weed will accidentally get caught by these valiant guardsmen of the spines that tower up in their midst; but this appears to annoy rather than gratify them, and their functions are not yet explained. They occur in some form or other in all echinoderms, yet contribnte no service to the animal that we can detect. Outside of them, forming a second circle about each spine, is a set of water-tubes, whose functions will be explained presently. Notice near the centre of the disk, on the back, the madreporic body-a small, smooth protuberance filled with openings, like a sprinkler, and then turn the star-fish over.

Though so tough and tuberculous above, on the under side it is soft and almost white in tint, except where the strong spines along the edges of each ray protect the soft parts between. In the very centre of the disk is the opening of the mouth. It contains no teeth, but is surrounded by an elastic tube and guarded by the hard edges of the skeleton-plates which hem it in. From this centre run five furrows, one down each of the arms.

"Throughout all this branch of the Radiates," observes Professor Forbes, "the reigning number is five. Among the problems proposed by that true-spirited bnt ecentric philosopher, Sir Thomas Browne, is one, 'Why, among sea-stars, Nature chiefly delighteth in five points?' and in his Gurden of Cyrus he observes: 'By the same number (five) doth 
Nature divide the circle of the sea-star, and in that order and mumber disposeth those elegrnt semicireles or dental suckets and esges in the sea-

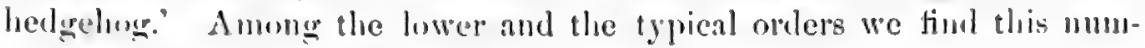
ber regulating the number of parts. Every plate of the sea-nrchin is

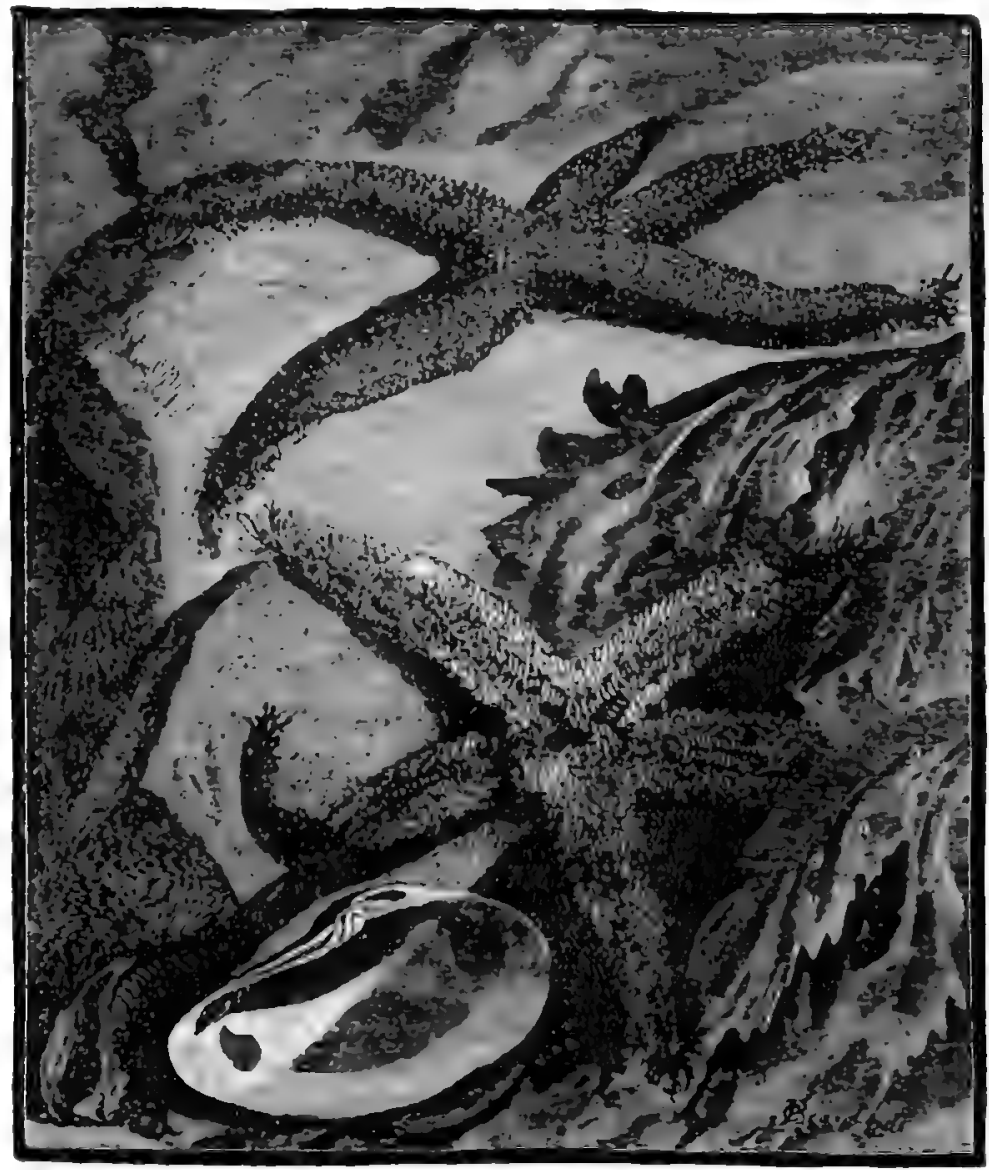

STAR-FISHES (LOWER FIGURE BHOWING CNDER BIDE AND AMBULACRA).

built up of pentagnal particles. The skeletons of the digestive, the arpuferons, and tegumentary systems equally present the quinary arrangenent: and even the cartilaginons franework of the disk of every sucker is regulated by this mystic number."

lint to return from this cligresion: Eatch furrow, with the exception of a narrow path down the middle, is filled with Heshy tubes, ending in a 
disk, which are so evidently the stal-fish's means of locomotion that you at once call them feet. This is true enough so far as their function is concerned-for Five-fingered Jack certainly does walk by means of them-but entirely wrong anatomically; no Radiate has "feet," properly speaking. In order to see how the little animal makes use of these hundreds of walking appendages we must dissect him.

It then appears that throngh the sieve-like madreporic body, on the back of the disk, filters a constant current of pure sea-water. This is received into a system of circular canals, which ramify on each side of every ray, and through minute openings in the broad plates on the lower side of the arms send ont fibres, which, when swelled full of water, appear as the rows of feet-tubes already mentioned. These feet-tubes are called ambulacroe; the grooves along each side of the arm, where they spring, and where they are supplied with water from the main canal underneath, the ambulacral grooves; while the plates themselves, and the whole concave under-surface between the spiny processes bordering the rays, form the ambulacral tract.

Now the star-fisl's body is always full of water; besides the large stream flowing in through the madreporic body, a constant inflow seems to take place by absorption throngh the thousand minute water-tubes that wreathe about each spine, notwithstanding that the microscope is unable to detect any opening in them. This insures that the ambulacræ shall always be full of water; but the creature can control this matter.

When he wishes to take a step he stretches one, a dozen, or a score of feet-tubes forward, and draws a slight amount of water from each, which causes a contraction of their sucker-disks, and gives them a firm hold. By a reverse process he lets go with his other feet, and by main strength drags his body up as far as he can. This operation, frequently repeated, would give a continuons movement to his body which is not ungraceful, as he dips down into a hollow or bends himself slowly over some obstacle. His movements are very deliberate, and his progress hardly as fast as the second-hand of a watch. It is to the fulness of this watersystem that the animal owes its plump appearance. Take him ont of the sea, and the water will pour out all over him in a fierce perspiration, which soon leaves him flat and thin on your palm. I may as well say here that any one can handle star-fishes without fear; the old ided that they were poisonous was a worthless superstition.

In addition to their water-system for locomotion, star-fishes have a heart and system of blood-ressels. This consists of two circular vessels, one around the intestine, and one around the gullet, or heart, intervening be- 
tween them. "There are no distinct respiratory organs, but the surfaces of the viscera are abundantly supplied with cilia, and doubtless subserve respiration; the sea-water being freely admitted into the general bodycavity by means of numerous contractile ciliated tubes, which project from the dorsal surface of the body" (Nicholson). There is a nervous system, also, in this apparently immovable and insensible denizen of the deep. A gangliated cord surrounds the mouth, and sends filaments ont along the centre of each arm to the little red speck discernible at the tip, which is an eye. How well they can see with these eye-specks is undecided, but there seems no doubt that they can perceive obstructions in their path, for they begin to get ready to mount them before actually striking against them.

The month, as I have said, is a mere circular opening without teeth. The stomach is reached through a short gullet, and of itself is not large, so that it is difficult to understand how the results of the tremendous gluttony for which this fellow is famous can be accommodated until we open him, and find that, as a part of the stomach, loose yellow pouches extend far into each arm, filling up much of the interior of the rays. When no great meal is to be eaten, these pouches or $\operatorname{coc} a$ are not brought into use; but when occasion arises they can contain a surprising quantity.

On the floor of each arm we have dissected is seen the ambulacral ridge, upon either side of which are the vesicles that supply the foot-tentacles, which may be filled or emptied at the pleasure of their owner. Above these, occupying the most of the interior space towards the end of the ray, and also appressed between the cæca and the upper surface towards the centre, are the grape racemose masses of the generative organs.

Few persons, probably, suspect that in so low a grade of beings the sexes are divided, yet this appears to be the case in the star-fishes. According to Prof. Alexander Agassiz, the males and females of our common species of star-fish can readily be distinguished by their difference in coloring: all those having a bluish tint being invariably females, while a reddish or reddish-brown color indicates a male. "When cut open, so as to expose the genital organs, the difference between the males and females is still more striking. The long, grape-like clusters of reproductive organs, extending from the angle of the arms, on both sides of the ambulacral system, to the extremity of the rays, present very marked differences in the two sexes. The ovaries are bright orange, while the spermaries are of a dull cream color. At the time of spawning . . the genital organs are distended to the utmost, filling completely the whole 
cavity of the ray, the abactinal system [i.e., the sides and back of the rays] being greatly expanded by the extraordinary development of these organs."

The two species common on the New England coast are Asterias arenicola and Asterias vulgaris, and though much alike otherwise, they

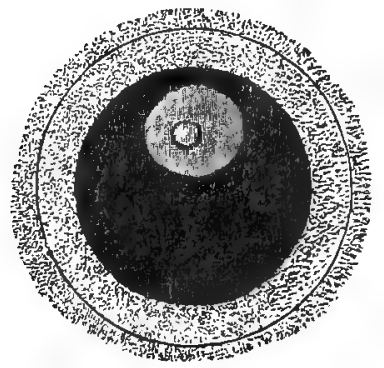

EGG OF THE STAR-FISH, AFTER FERTILIZATION. have different times of spawning-the former (Massachusetts Bay to Florida) throwing out its eggs a fortnight or more earlier in the summer than the latter, whose range is more northerly and lience in colder waters. Their period of spawning, also, is very short, comprising only three or four days. The eggs produced by the females, as well as the sperinatozoa sent out by the males, find exit from the body through five very small holes, in a series of large plates on the back at the angles of the arms. Such eggs as are fortunate enough to meet with spermatozoa in the water, before being overtaken by some form of destruction, are fertilized, and immediately begin a very curious series of changes in embryonic growth.

This embryology, which has been described by Alexander Agassiz, is like that of no other group of animals, but may be roughly compared to the transformations of a butterfly in the chrysalis. The larva which hatches from the star-fish's egg is entirely unlike its parent in form or structure, being an oddly-shaped, ragged, transparent little creature, permeated through

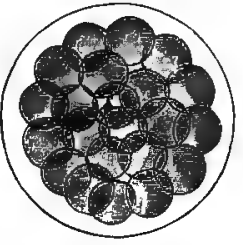

AN EGG NEARLY READT TO HATCE.

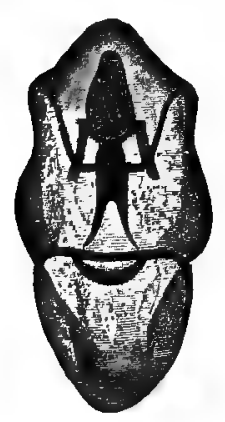

AN EMTRYO BTARFISH AT AN EARLY STAGE, SEEN EDGEWISE. and through by water-tubes. When perfected, this larva is called a brachiolaria, and swims around for several days by means of vibrating cilia, which keep it whirling and bobbing about, not choosing its course, nevertheless, by an exertion of its will, but a prey to all the chance breezes and currents that can get it in their power.

These larvæ, says Mr. Agassiz, are to be found floating in large numbers at night, though never by day, near the surface, among cast-off skins of barnacles, which furnish them with food during the time when they swim freely about in company with multitudes of small crustacea, annelids, and hydroids. At such a time they are fit food for slell-tish, and no doubt many fall into those 
treacherous small currents that lead into an oyster's, clam's, or mussel's month. This helps to even up the account which the adult star-fishes are making by their daily onslaughts npon these same mollusks.

The jaunty, free career of the brachiolaria, however, is soon over. Changes begun before they were understood now begin to alarm him. He is losing his shape and assuming a strangely symmetrical, five-armed form, covered with soft spines and tentacles. Before he knows it, and without the loss of a single portion, the brachiolaria, by absorption, has lost himself in the body of a true yonng star-fish, and finds himself slowly acquiring the stiff armor and dignified mien which marks his approach to an adult condition. He ceases his gay wanderings and sinks to the bottom, or crawls upon the frond of some floating sea-weed. This occurs when he is about three weeks old. But now that he is no longer an embryo, but a real baby star-fish, his growth is very slow. Mr. Agassiz says that by arrang-

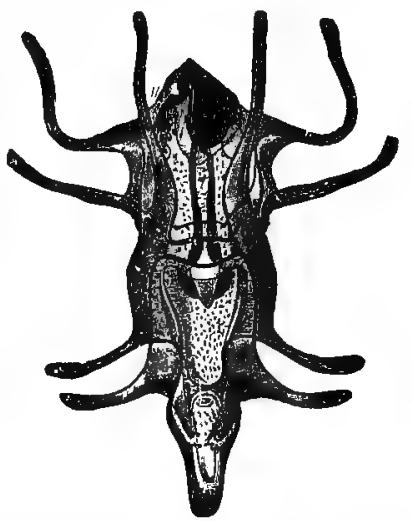

A MORE ADVANCED EMBRYO, SWIMMING BY ROWS OF CILIA ALONG THE PROTUBERANOES. ing the star-fishes, big and little, found upon our rocks, into series according to size, we may roughly estimate the number of years required by them to attain their full development,

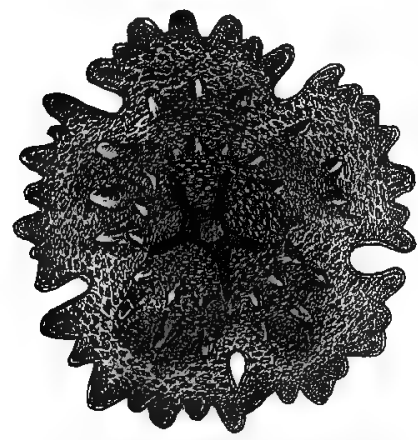

A YODNG STAR-FISH. which he thus calculates to be about fourteen. During the earlier years the growth is more rapid, of course, than later. One young specimen, kept in an aquarium at the Cambridge museum, doubled its diameter in five months. That they begin to spawn when six or seven years old, or hardly half-grown, is ascertained; but as to how long they may live after that, provided the dangers of the sea are escaped, we hare no information that I am aware of.

The size to which they attain varies in different species. The rare British Uraster glacialis, Ag., has been seen thirty-three inches in diameter, and some even larger than this have been reported from near Eastport, Maine, where echinoderms abound in greater number, perhaps, than anywhere else on our coast. South of Cape Cod, however, it is rare to see one measuring more than ten inches across, and the great majority do not exceed six. 
The destructiveness of these creatures has long been recognized by naturalists and fishermen alike. In Bishop Sprat's "History of the Royal Society" of London, we are told that many years ago the Admiralty Court of England laid penalties on those engaged in the oyster-fishery "who do not tread under their feet, or throw upon the shore, a fish which they call five-finger, resembling a spur-rowel, because that fish gets into the oysters when they gap and sucks them out." Numerous accounts might be given of instances when great damage had been done the shell-tisheries, particnlarly along the Welsh and Cornish coasts, by star-fishes, in a very short time. Oysters, not only, but clans and scallops of every sort, fall a prey to some of the many spiny raiders, whose size or habit of living in deep or shallow water fits them to attack one or another sort of mollusk.

Couch, in his "Cornish Fauna," notes that the Uraster rubens, which is called clam or "cramp" in Cornwall, and occurs there in multitudes in spring, infests the fishermen's crab-pots, to steal the baits; and a Belfast man reports that he has had star-fishes frequently seize his lng-worm bait and be brought $\mathrm{up}$ on his hook while fishing. Mollusks, then, are not their only food. The carrion of the sea is eaten by them with roracity, and in this respect they are beneficial to us and the rest of animal life.

I do not propose to give a history of British star-fishes, but before leaving them must tell one or two superstitions attached to them by seafaring men, each of whom is so ready to invest with supernatural qualities every strange product of that mystery of mysteries, the sea, whose inscrutability and might impress him with supernal power, and excite his wonder more and more the longer he is acquainted with its unajesty, its moods, and its inhabitants.

Forbes records that at Scarborough the fishermen call the big Asterias aurantiaca-a very destructive species-the "butt horn." "The first taken," he says, "is carefully made a prisoner, and placed on a seat at the stern of the boat. When they hook a 'but' (halibut) they immediately give the poor star-fish its liberty, and commit it to its native element; but if their fishery is unsuccessful it is left to perish, and may eventually enrich the cabinet of some industrious collector."

In Ireland, it appears, the folk-lore of this subject is more grum. "The star-fishes are called at Bangor (County Down) the 'Devil's fingers' and the 'Devil's hands,' and the children have a superstitious dread of touching them. When drying some in the little garden behind my lodgings, I heard some of them on the other sicle of the hedge put the following queries: 'What's the gentleman doing with the bad man's hand? Is lie ganging to eat the bad man's hand, do ye think?" " 
Not a superstition, but an entire error was the belief, which I find still existing in the United States, that the star-fish will poison painfully, if not fatally, the hand of any one touching it. Our oystermen know. better; but I can tell them that the belief is very old. Pliny, who lived. during the first century of the Christian el"a, asserted that star-fishes "can burn all they tonch." This proves he took hearsay evidence, which a naturalist is never safe to do, and did not handle them himself to see. Aldrovandus and Albertus, who wrote a few centuries later, followed the same love of the marvellous, in spite of common-sense and easy proof to the contrary, telling their credulous readers concerning these creatures, that "their nature was so hot they cooked everything they meddled with." Possibly we may find here the origin of the stew, the roast, the takehome-a-fry-in-a-box, which otherwise remains very obscure. Finally, some out-door students came along, picked up star-fishes, found them harmless, and freed the foolish old tomes that called themselves "natural histories," but constantly set nature aside for the marvellous and absurd, from one more taint upon the name of observer.

The tale did not wholly lose its hold upon the minds of the ignorant, however; and even the learned have sought, until lately, to prove that some sort of an acrid fluid was discharged by the skin of the animal. This false idea arose, perhaps, from confounding the star-fish with the varions Meduso, sometimes called "cross-fishes;" or, possibly, it is an outgrowth of the attempt to account for the insidious destructiveness of the five-finger, which for a long time was misunderstood.

In Boston, recently, one of the oldest oyster-dealers and planters gravely instructed me in the manner a star-fish attacks lis victim.

"Crawling round the bottom," he explained, "the star accidently gets afoul a bed of oysters. He don't know what they are, mebbe, but there they all lie with their shells a-gapin', after the nature of oysters. Poking round amongst 'em he accidently, as it were, gets the end of one 'of his arms into an open shell, and the oyster of course shuts down on lim. Now, sir, he can't get away, but the oyster can't live but a little while with its shell open, and after a few honrs he is dead. Then he lets up, and the star makes a meal off him right there-takes him on the half-shell in his own gravy, as it were."

This is the first and last time I ever heard an American talk this nonsense, though many have expressed an ignorance of the whole matter, which was a discredit to their eyesight; but in reading Prof. Edward Forbes's "British Starfishes," where he mentions the cripples so frequently taken among star-fishes, I lately found the following paragraph: 
"The oystermen believe that it loses its rays in consequence of its oyster-hunting propensities. That it insinuates an arı into the incautious oyster's gape, with the intent of whipping out its prey, but that sometimes the apathetic mollusk proves more than a match for its radiate enemy, and closing on him holds him fast by the proffered finger; then the cross-fish, preferring amputation and freedom to captivity and dying of an oyster, like some defeated warrior, finding

'The struggle vain, he flings his arms away, And safety seeks in flight.'

"This story has long been believed. Link gives a vignette representing the mode of attack, with the motto "sic struit insidias." "

Everybody who knows anything about it understands now, of course, that all this is absurd. The star-fish goes about his foraging in a much more effective and sensible way. Indeed, he excels almost any other animal worth calling one in economy of exertion in eating, since to secure, swallow, and digest his food, when once he has forced an entrance to the victim's shell, is combined in a single operation.

Having met with an oyster, scallop, or other thin-shelled molluskand young ones are preferred because their armor is weak-the star-fish folds his five arms about it in a firm and deadly grasp. Then protruding the muscular ring at the entrance of his stomach throngh the circular opening in the centre of the under side of the disk, which I have described, he seizes the thin, newly grown, posterior edge of the shell, which oystermen call the "nib" or "bill," and little by little breaks it off. It has been surmised that the gastric juice decomposed the edge of the shell until an opening was effected; or, entering, paralyzed the mollusk, until he relaxed the muscle which held the protecting valves together. But I do not think either of these suppositions supported by fact. The operation is proceeded with too rapidly to wait for the slow action of the stomach-acids upon the carbonate of Jime in the shell; and the vital parts of the mollusk are too far inward and sluggish to be promptly affected by any such acids. Moreover, it seems unnecessary, since the appearance of every shell attacked at once suggests a breaking down, chipping-off movement, which the star-fish might easily produce by seizing and suddenly pulling down with the suckers nearest the mouth, or by a contraction of the elastic opening of the stomach.

However managed, the thin edge of the shell is broken, until an entrance is made which the occupant has no way of barricading. Then the burglar protrudes into this entrance the distensible mouth of his stomach 


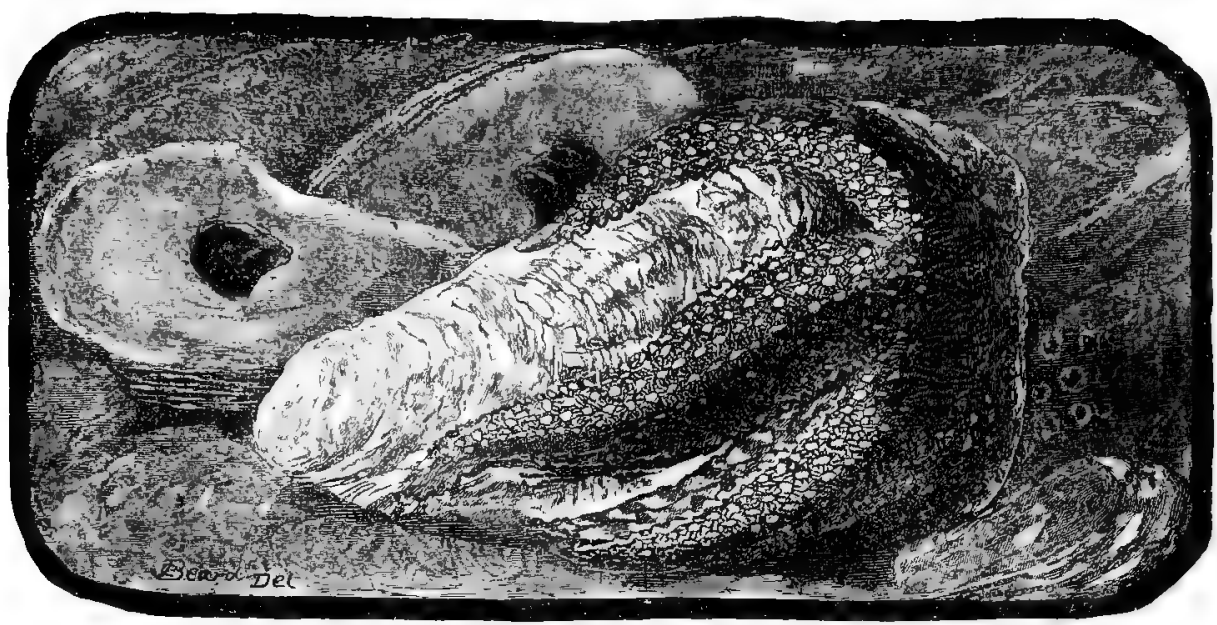

DINING UPON AN OTSTER.

until it can seize upon the body of the mollusk. The consumption of this begins at once, and as fast as the poor oyster's or seallop's body is drawn within its folds, the capacious stomach is pushed farther and farther in, until at last, if the mollusk be a large one, the pouches that I have described as packed away in the cavities of the rays are also drawn forth, and the star-fish has substantially turned hinself wrong side ont.

If dredged at this stage, as many examples constantly happen to be, and dragged away from his half-eaten prey, his stomach will be seen hanging ont of the centre of his body for a distance, perhaps, equal to half the length of one of the arms, and filled with the juices of the oyster he has just devoured, whose body, within the shell, will be found almost as squarely trimmed as conld have been done by scissors. If put very gently into a bucket of salt-water, and left in peace, the star-fish will straighten himself ont, and slowly retract his extruded abdomen, as he would have done, after his meal was digrested, had he not been disturbed; but if the least violence is used he will spurt out the liquid, and quickly draw the distended pouch back into his body. As a rule, however, the angry fisherman does not have patience for these experiments.

This process is the one followed in the case of largesized molluslis. Very young oysters and other small prey are enveloped in the stomach, shell and all. The gastric juice then kills and dissolves out the soft parts, ufter which the hard crust is thrown away by the eversion and withdrawal of the stomach.

When oysters first were cnltivated along the American coast, and this 
enemy first became known, the oystermen used to save all that they caught in their tongs and dredges, and pile them in a corner of their boats until evening. Then they wonld collect them into small packages, and draw a cord around each lot tightly enongh to cut throngh it. This done, the remnants were cast overboard and considered done for. But this was entirely a mistake, as was presently found out. Five out of six of these fragments not only retained life, but renewed thie lost parts and became active again. Thus, instead of diminishing the pest, these inen were directly increasing it, since they were making two or three new starfishes out of each captive. It was a case of multiplication by division, which may be an invariable paradox in mathematics, but is by no means always so in zoölogy.

Star-fishes often lose one or more of their rays, but reproduce them. Forbes figures one, where four ont of the five arms bad been broken off in some way, and had just begun to be replaced by the little stubs of new growth. This gave the animal, with one fyll-sized limb, the shape of a spike-headed bludgeon. Indeed there are certain members of the family, found in all seas, known as Ophiurans, or snake-armed sea-stars, which are liable to commit apparent snicide, hurling themselves to pieces the instant they are disturbed. The habit belongs, also, to a few larger forms, but, so far as I am aware, is never practised by any of our familiar American star-fishes, who seem to prefer to take their chances rather than voluntarily fling away their limbs. This fragility and spitefulness of certain of the star-fishes is humoronsly described by Forbes, in his account of one large British seven-armed species, the "lingthorn," or Luidia fragillissima. Having been cheated out of a previous specimen by its breaking itself to pieces, Mr. Forbes took with him, on his next collecting expedition, a bucket of cold fresh-water, to which article star-fishes have a great antipathy. "As I expected," he says, "a luidia came up in the dredgea most gorgeous specimen. As it does not generally break up before it is raised above the surface of the sea, cautiously and anxiously I sunk my bucket to a level with the dredge's mouth, and proceeded in the nnost gentle manner to introduce luidia to the purer element. Whether the cold air was too much for him, or the sight of the bucket too terrific, I know not, but in a moment he proceeded to dissolve his corporation, and at every mesh of the dredge his fragments were seen escaping. In despair I grasped at the largest, and bronglut up the extremity of an arm with its terminating eye, the spinons eyelid of which opened and closed with something exceedingly like a wink of derision."

Now that I lave spoken of the "brittle-stars," as the ophiurans are 
well called; I may as well quote Mr. Forbes's account of the trouble they give on the French and English coasts, which entitles them to a place in this essay on an enemy of the shell-fisheries. He remarks:

"The common brittle-star often congregates in great numbers on the edges of scallop-banks, and I have seen a large dredge come up completely filled with them; a most curions sight, for when the dredge was emptied, these little creatures, writhing with the strangest contortions, crept about in all directions, often flinging their arms in broken pieces around them, and their snake-like and threatening attitudes were by no means relished by the boatmen, who anxiously asked permission to shovel them overboard, superstitionsly remarking 'the things weren't altogether right.' Rondeletius ... says they prey on little shells and crabs. They constitute a favorite article of diet in the codfish's bill of fare, and great numbers of them are often found in the stomach of that fish."

Star-fishes are rarely found dwelling upon a muddy bottom, nor do they like clean sand very well. Upon the mud it is difficult for them to move about; while the open, smooth sand holds little food, and is likely to be shifted by a storm too quickly for them to escape burial. Theil home, therefore, is chosen on rocky consts, where submerged reefs afford plenty of craggy points for them to cling to, and where crannies at once serve as homes for the animals they feed upon, and safe hiding-places for themselves. Beds of jingles (Anomia), deckheads (Patella), key-hole limpets and other rock-loving mollusks, are strongholds of star-fish life.

The amount of damage done to the oyster-fisheries of the American coast by sea-stars became an object of constant inquiry by me during my investigation into the condition and statistics of the oyster products and industries of the United States as a special agent of the Tenth Census.

This pest I found to be confined to northerly waters. To the sonthward of Sandy Hook, at the utmost, no harm is reported, since the starfishes are extremely few, and almost wholly confined to the mussel-beds in the inlets. At Eastport, Maine, all attempts to bed down northern stock, or to transplant and raise any northern seed-oysters, have been completely finstrated by hordes of giant star-fish, which ate up the mollusks almost as fast as they could be put down. Here, then, the sea-stars are responsible for an entire disuse of otherwise available privileges for oyster-culture.

The same condition of affails exists to a great extent on the rest of the coast of Maine, and I am not sure but the mysterious extinction, at about the date of the advent of Europeans, of the once extensive living beds of oyster's between the mouths of the Kennebec and the Merrinac, was large- 
Iy due to the attacks of this five-fingered foe. At Portland, however; where many southern oysters are laid down every year, I heard little complaint. This immunity is probably due to the fact that no young oysters are planted here, or grow naturally; and also to the fact that the beds are made upon muddy flats, in shallower water than star-fishes enjoy. The same is true of the whole of Massachusetts Bay, except Wellfleet, where the planter's count sea-stars among the enemies, bit secondary to the three or four species of mollusks that prey upon the planted beds.

South of Cape Cod, however, where oysters spawn and grow naturally, and beds of cultivated oysters are raised from eggs and infancy, star-fishes are plentifnl. All of the shores of Buzzard's Bay are infested with them, and from there to the western extremity of Long Island Sound they do enormous damage annually to the oyster interests - a damage probably not over-estimated at $\$ 250,000$ a year. The south shore of Long Island and the bay of New York are less afflicted. Their attacks are not uniform and continuons, it appenrs, but vary with years, the time of the year, and other circumstances. A steady increase, however, has been observed in their numbers wherever oyster cultivation has been carried on for any considerable length of time. The planters at Providence, New Haven, and Norwalk, whose memories go back for twenty-five years or more, relate that in their early days this plague was not regarded as of any consequence, and that the star-fishes are steadily increasing. Such a report is no more than we should expect, in view of the enormous increase of the food afforded them by oyster-cnlture.

There have occurred times in the past, nevertheless, as now happens at intervals of a few years, when an excessive crowd of star-fishes invaded the beds. Such a disastrous visitation was witnessed in the Providence River, Rhode Island, about 1858. The star-fishes came in "sudden droves which burned up everything." The planting-grounds were mainly on Great Bed, about three miles below the city of Providence, and of all this extensive tract only two acres escaped, owing their safety to the fact that just before that they had been partially buried under a layer of sunken sea-weed and drifted matter. Another of the planters had his heaviest bed between Field's Point and Starvegoat Island (which probably were not long ago connected), where the low tide left them so nearly bare that his men could pick up the star-fishes, while his rivals had no means of combating them in the deeper water. In the general scarcity that ensued he made large profits from this resened bed, and got a start to which he owes a large part of his present eminence in the New England trade. So complete was the destruction caused by this visit, that the State 
revoked the leases of all that ground, and the planters left it wholly for a new tract at Dianond Reef, where the water was so fresh that star-tishes could not live. This single inroad upon Providence River probably cost the planters there $\$ 150,000$. It occurred late in the summer, and the miranders stayed there, picking up the fragments of the feast that remained, until winter. Then a heavy fall of snow and rain, in conjunction with an unusually low tide, chilled and so completely freshened the water as to kill them all off. So it is related; and it is said to have been some year's before that tract was re-occupied by planter's.

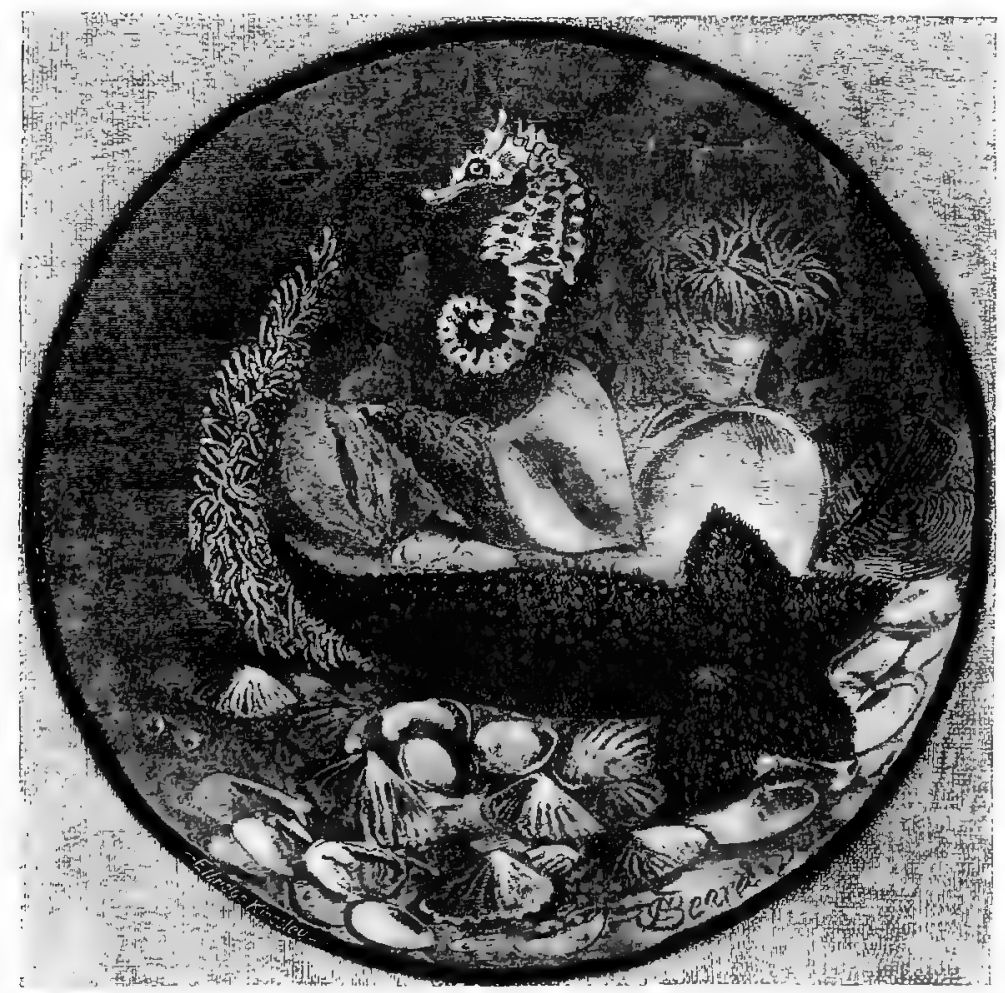

REPRODTCING FOLIR LOS'T ARMS.

Similar traditions exist elsewhere along this "sound" coast, and the planter's stand in constant foar that the army of the enemy, which they daily fight, may at any time be suddenly reinforced from some invisille. quarter to an extent which shall make any contest nseless. In 1878, for example, after some rongh and gloomy weather in the latter part of Oc. 
tober, a planter at Pocasset, Massachusetts, went ont in his boat to look at his oyster's, which lay in three to five feet of water. He at once noticed that the star-fishes had made a raid upon him under cover of the storm. Taking an eel-spear as a weapon, he forked up 2500 by actnal count within the next two days, and later gathered 500 more. In spite of this they ate up about 300 bushels from his beds alone. Adding what his neighbol's suffered, he considers the single week's loss at that point to lave been about 1000 bushels, worth $\$ 1200$.

At Warren, Rhode Island, I saw once a pile of dead star-fishes, said to amount to 1000 bushels, which had been dredged off the beds in the river there. A bushel of living sea-stars contains from 100 to 200, according to size-say, 150 on the average. In drying, however, the bulk of a bushel is reduced three-fourths. Therefore this decaying heap, ready to be turned into manure, represented something like 1000 by 150 by $4=$ 600,000 star-fishes. Suppose them to be the only star-fishes caught in Warren River, and to have eaten only one oyster each before their capture, and we have 600,000 mollusks, or abont 3000 bushels, destroyed. But the oystermen say not one in twenty five-fingers gets eanght, and that 50,000 bushels would come nearer to each season's loss of young and old oysters. Eqnally great heaps can be seen at Fairhaven, Conn.

It is in the latter part of the summer and in the autumn that the starfish pest occurs in its greatest violence along the Rlode Island and Counecticnt coasts. Then they, themselves, are done with their spawning and have renewed their vigor, and the young of all sorts of mollusks, crabs, and other prey abound upon the shores and invite the five-fingers to an easy repast. It is at this season that the sudden appearance of great bodies of star-fishes make the heart of the planter sink within him; for he knows that if they once attack a bed of his, they march straight throngh it, and leave as dead a path as if it had been swept by a fire. It is utterly useless to struggle against them, except by putting on a large force of men and taking up all the oysters on the bed. On more than one occasion steamers have been employed, at a large expense, in order to hasten the work of dredging. To what a great extent this is now done in Long Island Sound, and the enormous depredations committed by this pest upon the oyster fisheries, can be learned by consulting the report for 1884 of the Connecticut Commissioners of Shell Fisheries.

I was told all along the coast, in order to account for the sudden unforeseen appearance of these bodies of star-fishes in the midst of an oysterbed, that they came rolling in from the deep sea in a compact ball, all clinging tightly together. This ball might be a foot in diameter, or as 
big as a barrel, and was rolled along on the bottom by the tide. When it struck the feeding-ground it went to pieces, and the individnal members at once began to devour the oyster next to them, beginning with the tenderest. I discredit the truth of this statement, since I never conld find an actual witness of such a phenomenon. The nearest I came to it was this: Captain Eaton, an old oysterman, whom I saw at New Haven, told me that several years ago, when he was with his brother at Norwalk, they raked up one end of a cylindrical roll of star-fishes clinging tightly together, which they hauled into their boat until it would contain no more, when they had to break the roll or "string," as he called it, which was a foot or more in diameter. He did not mention any core inside of this cylindrical body, which was solid star-fishes and nothing else.

There is no reference in books, that I know of, to anything of this nature, except that Forbes quotes a French writer, Deslonchamps, of 1825, who says that on the French coast, when the tide was out, and while two or three inches of water remained on the sand, "he saw balls of Asterias rubens, five or six in a ball, their arms interlacing, rolling out. In the centres of the balls were Mactrce stultorum [a kind of large clam] in various states of destruction, but always unable to close the valves, and apparently dead."

How much faith is to be put in this acconnt, credited and repeated by many fishermen, and how much of it is pure fable, is hard to say from present data. In general it is known that our star-fishes live and breed among the rocks, begin to feed in summer, but do not move about much when once they strike a feeding-ground, and either perish or retreat to deep water when the cold of winter approaches. Mussels are preferred to oysters or clams, though I have heard it asserted that they will even make their way into a quahaug, if hard pressed. The smaller, thin-shelled bivalves fall an easy prey to them. One of these (Arca virgata?) is called the "blood-quahang," and the Providence River men say that when it is present the star-fish will take little else.

The only offsetting value in this plague, that $I$ am aware of, is its usefulness as a manure, for which purpose those taken by the oystermen are saved. They are especially recommended for grape-vines. Large quantities are thus made use of in Great Britain and France.

"Anciently," as I have read, "the urasters were used in medicine. They were given internally as a decoction with wine, in hysterical diseases and against epilepsy. The physicians of old times, members of a profession never very remarkable for logical acumen, applied them externally in hernia, from some fancifnl analogy between their pouting 
stomach and the appearance of the rupture. Any medical man whó would wish to revive the practice will find the prescriptions carefully gathered together in Link, who, however, does not appear to have put much faith either in the medical or gastronomical virtues of star-fishes; yet, conceiving it necessary to find some use for them, according to the manner of his times, he tells us they are of nse to man, not because they serve as food to him themselves, but becanse they feed the fishes, and the fishes feed him, adding, "miror hinc et in providentia divina sapientiam.",

In spite of his belief, however, I do not know any fishes that feed upon the sea-stars, except the cod. Connecticnt men say that the coot (Fulica americana) is fond of young star-fishes, as many as fifty of which have been found in the crop of a single bird. It is not unlikely.

The question following a knowledge of the facts which have been given above is, What can be done to prevent, or at any rate lessen, the ravages committed by the star-fishes upon oyster cultivation? This is a very hard question to answer. The boundless tracts of the outer sea harbor them beyond any hope of extermination by us, and all operations must apparently be confined to the small localities occupied by the oysters. Here, again, the expense involved in ridding one's property of the pests, makes it a question whether it were not more profitable to let them alone. Possibly this might be the case in individual instances; and probably it has been found so, and acted upon almost universally up to the present. The result is a colonization and increase of star-fishes, which forsake the single localities to which they were once confined and devastate a whole neighborhood. Erery man now suffers through his neighbor's neglect as well as his own.

The oystermen who own contiguous beds should combine during the summer to dredge the star-fishes all off a certain district, and divide the expense or labor equally among them all. Such combined and persistent work, when the plague first appears, will certainly clear them off; and when once they are got rid of, they will not be again troublesome until the following season, and then in less numbers. There is no more reason why the star-fishes cannot be so reduced in Long Island Sonnd that they shall not be harmful to the oyster-beds, than there is why the Canada thistle cannot be kept down in the three shore counties of Connecticut. It is merely a question of steady labor intelligently applied.

But I have discussed this matter of prevention more fully in my report to the Tenth Census upon the Oyster Iudustries (chapter v., page 231), and need not dwell further upon it here, where it is scarcely appropriate. 


\section{XII.}

PERIWINKLES • AND OTHER OYSTER-PESTS.

THE space between tide-marks, and the sheltered estuaries all along the sea-coast, are infested by a great army of mollusks, crabs, and fishes, whose food is found in the flesh of other mollusks. To obtain this they are provided either with powerfully muscular mouths or with file-like tongues and flexible sucking tubes. To these banditti the beds of oysters are so many markets, and, in pursuing what to them is the proper and the only possible coudnct of life, they become pests to the oyster planter only second to the star-fishes. Like those hated animals, however, these conclis, periwinkles, and sea-snails, with their industrious associates in mischief, creeping and swimming, present many points of interest and great suggestiveness to the naturalist.

The most important of the carnivorous mollusca, considered as enemies of the oyster and pests to the planter, are the two large spiral mollusks, Sycotypus canaliculatus and Fulgur carica, "which along the const are confounded under the names "periwinkle," "winkle," "wrinkle" (New England), and "couch" (Southern), with occasionally a distinguishing prefix. Various other large shells also come under these generally applied names; and in the Gulf of Mexico we have, additionally, the "lking conch," "queen conch," and "horse conch."

The sycotypus is more common north of New York-thongh it does not exist at all beyond Cape Cod-while along the coast of New Jersey and southward it is the fulgur which is chargeable with nearly all the mischief perpetrated, since the other species is rarely seen. Occasionally, as Verrill mentions, specimens of both may be found crawling on sandy flats or in the tide-pools, especially during the spawning season, but they ordinarily live in deeper water and on harder bottoms off shore. It is needless to say that they do not burrow at all, thongh they are able to in-

* Some late studies in their anatomy (the figure on p. 141 gives a good idea of the shape of the living animal in both) go to show that both these mollusks are species of Fulyur, and more closely allied than has hitherto been suspccted. 
sert the posterior part of the foot into the sand sufficiently to afford them a strong anchorage against currents. A very soft or a very rocky bottom are equally avoided by them.

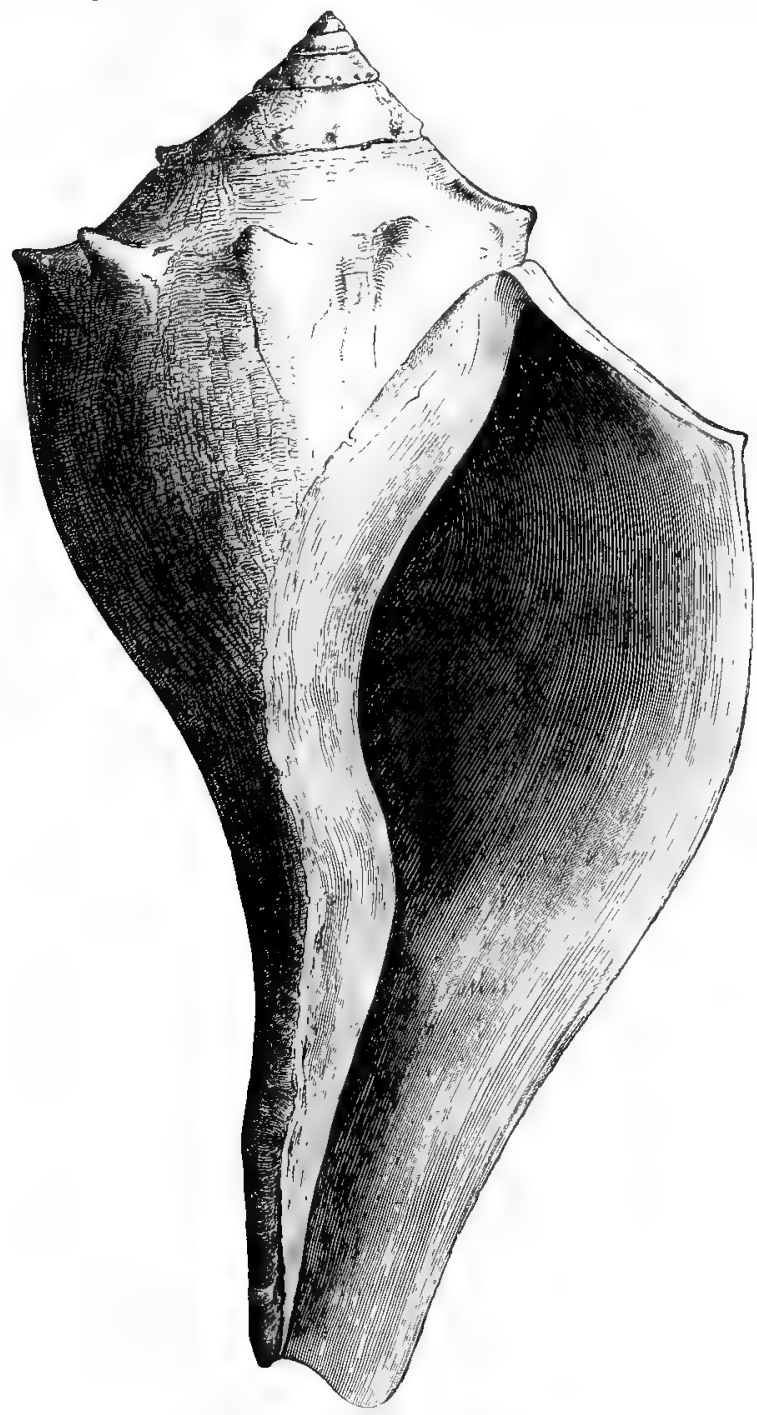

SHELL OF FULGER CARICA.

The curious egg-cases of these mollusks, to which the names "searuffle" and "sea-necklace" are often given by fishermen, always attract the attention of visitors to the sea-side, who find them cast rpon the 
beaches; and we can well echo the pions exclamation of the old historian of Martha's Vineyard: "The Author of nature makes a wonderful and copious provision for the propagation of this worm." The eggs are discharged in a series of disk-shaped yellowish capsules, parchment-like in texture, nnited by one edge to a stout stem of the same kind of material, often a foot and a half or two feet in length. "The largest capsules, about an inch in diameter, are in the middle, the size decreasing towards each end. On the outer border is a small cirenlar or oval spot, of thinner material, which the young ones break through when they are ready to leave the capsules, each of which, when perfect, contains twenty to thirty or more eggs or young shells, according to the season."

Dr. Elliott Cones, who has observed Fulgur carica forming its cases at Fort Macon, North Carolina, states that the females bury themselves a few inches below the surface of the sand on the flats that are uncovered at low-water, and remain stationaly during the process. The string of capsules is gradually thrust uprard as fast as formed, and finally protrudes from the surface of the sand, and, when completed, lies exposed on its surface. The string begins as a simple shred, two or three inches long, without well-formed cases; the first cases are small and imperfect in shape, but they rapidly increase in size and soon become perfect, the largest being in the middle; the series ends more abruptly than it began, with a few smaller and less perfect capsules. The number of capsules varies considerably, but there are usually seventy-five to one hundred or more. At Fort Macon Dr. Cones observed this species spawning in May, but at New Haven they spawn as early as Mareh or April. It is probable that the period of spawning extends over several months.

The "necklaces" of both species present much the same appearance, but a little experience enables one to distinguish them. In those laid by fulgur the sides of the capsules are nearly smooth, but the edge is thickened along most of the circumference, and crossed by numerous sharp transverse ridges or partitions, dividing it into facets. The capsules belonging to sycotypns are larger and thinner, having a thin, sharp, onter edge, while the sides show radiating ridges or raised lines. The small shells may often be found within the capsules, and thus identify the species withont any cliance of mistake. Their exit, when ready, is made throngh a circular hole, abont one-tenth of an inch in diameter, in the periphery of the capsule. This lappens early in June in Long Island Sound.

Eggs as much exposed as these are subject to numberless accidents, such as being drifted ashore, gronnd to pieces by storms, and no doubt 
eaten by bottom-feeding fishes, so that only a few eggs out of the hun-

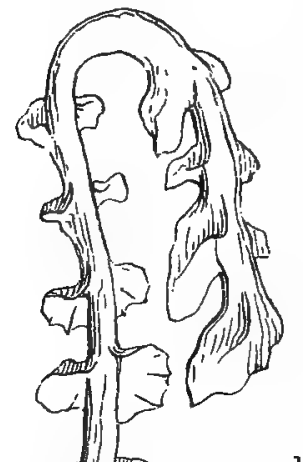
dreds in each "necklace" are ever born - or", accomplishing that, are able to survive the perils of unprotected youth and reach adult age and strength. Having once done so, however, this mollusk probably lives to a very great age.

An examination of a specinen will show that in both species the muscular part is large and strong and the mouth powerful. The food of the conch being mainly the flesh of other mollusks, its method of killing them is one of brute strength, since it is unprovided with the silicions, file-like tongue of the small "drills." The conch is a greater savage than this. Seizing upon the unfortunate oyster, unable to run away, he envelops his shell in the concave undersurface of his foot, and, by just such a muscular action as you wonld exert when grasping an object in the palm of your fist, crushes the shell in to fragments and feasts at leisure on the flesh thus exposed. Where oysters or other prey are

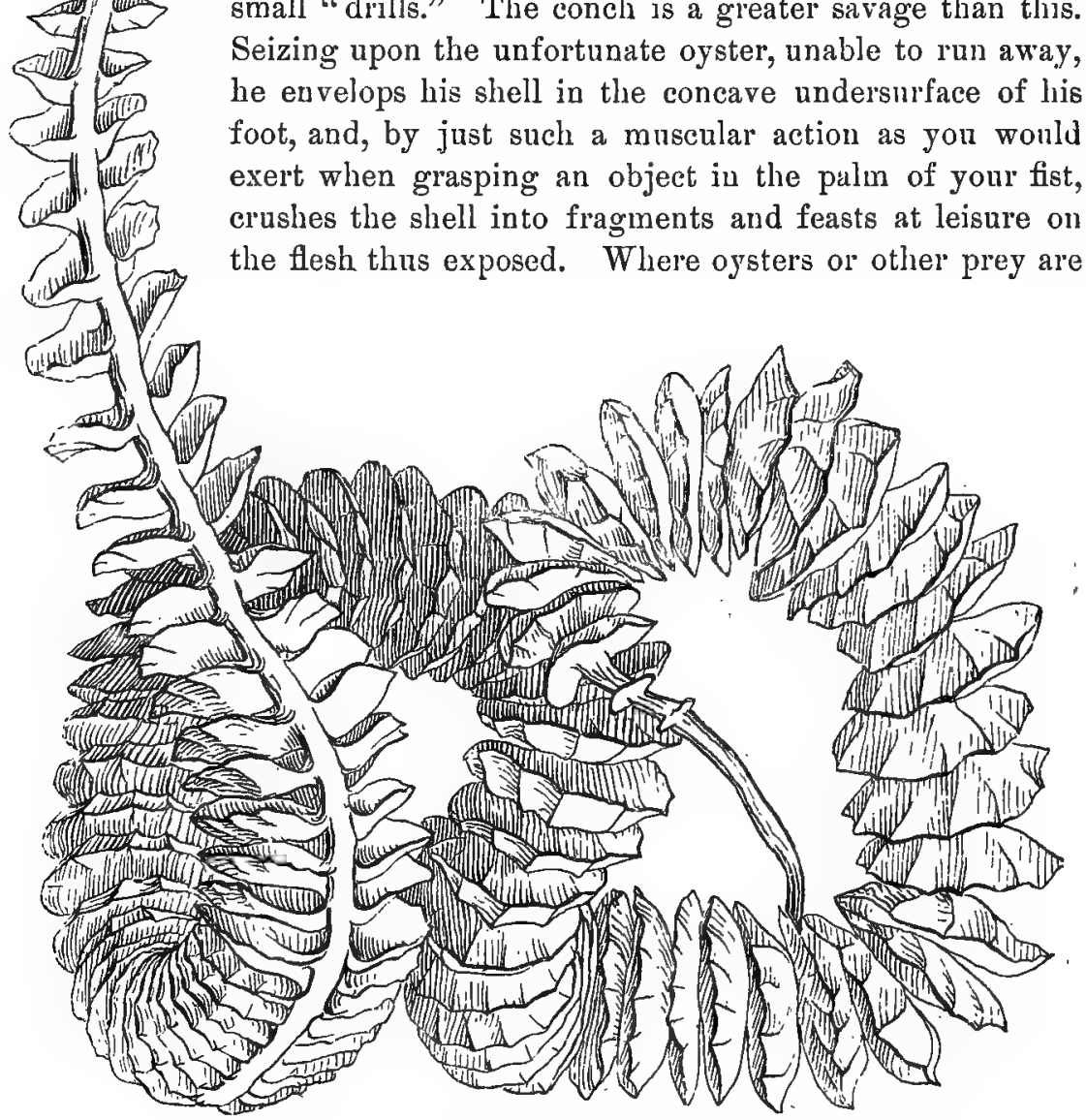

A "SEA-NECKLACE"-EGG-CA\&ES OF FULGUR. 


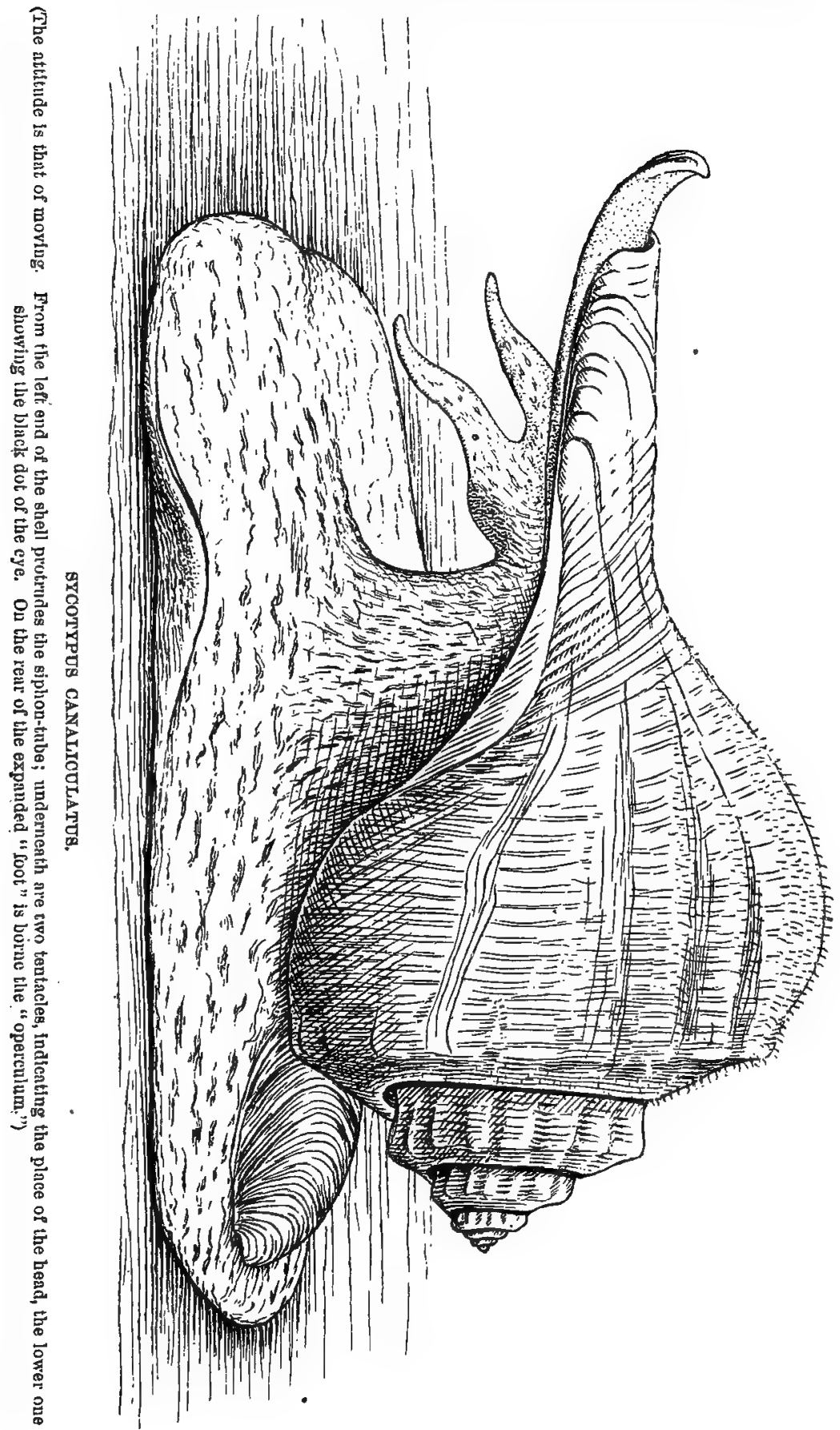


abundant, this operation is quickly repeated and vastly destructive. One planter in the upper part of Buzzard's Bay, Massachusetts, where this pest is very troublesome, told me that one winkle was capable of killing a bushel of oysters in a single hour. They do not confine themselves to oysters altogether, of course; any mollusks or other marine animal, sluggish and weak enough to be caught and broken up, suffer from their predacity. I was told in New Jersey, by an intelligent man, that the conch would even draw the razor-shell out of his burrow and devour it. If this be true, no doubt the suft clam also falls a victim to the same marauder, but the quahaug in his massive shells is generally safe.

The oyster-beds most subject to attack and harm by the winkles and conchs are those planted in water which is quite salt, as is the practice in New England and in Long Island Sound. The beds of the Great South Bay, Staten Island, and the southern Jersey coast, are well protected by the outer beaches from the sea, and to these barriers owe their immunity from the fulgur, while the sycotypus, though present inside the beaches, seems to do small damage. Oystermen will tell you, also, that beds which are disturbed from time to time by the planter will suffer more harn than neglected beds, especially in summer. Where planting has gone on for many years, these predatory mollusks have visibly increased in numbers-the natural result of abundance of food.

The shells of both were used by the Indians of the coast ceremonially, and as material for the making of white wampun, a description of which will be found in another chapter. From them, also, were fashioned articles of service or ornament, such as maces, hoes, trowels, spoons, and dippers ; sometimes even yet they are called "ladle shells." The Indians ate the animals, too, when hard-pressed for food, and have been followed in this practice by the whites, to some extent. De Voe says they used sometimes to be sent into Catherine Market, New York, from Long Island " "but," he adds, "they are not generally relished, being somewhat strong flavored. They are mostly lised by the poor who live near the coast." Several foreign mollusks, not greatly different, are utilized-generally by boiling-and perhaps proper cooking would make these conchs more palatable than they have hitherto proved. In Florida allied species are occusionally eaten; and often, in times of scarcity, they are canght and cooked to be fed to dogs.

Perhaps as destructive an agent as the conchs and winkles is the fish known as the drum-fish (Pogonias chromis, Linn.); for, althongh this plague is not steadily present, when it does occur the devastation is enormous. "Let ns make a visit," says Samuel Lockwood, that brightest 
of American writers on animals and ont-of-door matters, "to one of these orderly communities in Oysterdom known as a 'planting-ground.' We are seated in a boat, and, gliding through the phosphorescent sheen, soon near the oyster-bed. It is a moonlight night, about the close of summer. Hark! what singular sound is that? Boom! boom! boom! Almost sepulchral, and, strange to say, it comes up from beneath the waters. One would think they were Nereids' groans. The oystermen, whose capital lies invested there, hear it with sad forebodings of loss which they cannot well sustain. It is one of a school of visitors who come with niaranding purpose. The fishermen call it the big drum. This drum-fish is known among naturalists by the name Pogonias chromis. The acknowledged beat of this scamp is the Gulf Stream, from Cape Cod to Florida; and a terrible fellow is this pogonias, for he is recorded as having attained the great weight of eighty pounds. One of twenty-five pounds wonld be but an ordinary affair. Their mouths are furnished with pavements of hard teeth, a little rounding on the top, and set together exactly as are the cobble-stones of the old city highways. The function of these dental pavements is to crunch the young oysters, which, after being crushed, are thus swallowed, shells and all."

It is the habit of these fishes to go in great schools. "On Wednesday, June 5, 1804," reads a record of Oyster Ponds, Long Island, " one seine drew on shore at this place at a single haul 12,250 fish, the average weight of which was fonnd to be 33 pounds, making in the aggregate 202 tons 250 pounds. This, undoubtedly, is the greatest haul of this kind ever known in this conntry. A hundred witnesses are ready to attest the truth of the above statement. They are used for manire." * I find in Niles's Weekly Register, July, 1833, a similar note: "Some days ago a haul was made in Great Egg Harbor Bay, near Bearsley's Point, Cape May, at which 218 drum-fish were caught, their entire weight being from 8000 to 9000 pounds. This is said to be the largest haul of that description of fish ever made in that bay."

Knowing the carnivorons propensity of the fish, one can easily inagine how an inroad of such a host must affect an oyster-ground. They do not seem to make any trouble, however, north of New York City, and rarely along the south side of Long Island. At Staten Island and Keyport they come in every few years and devastate thousands of dollar's' worth of property. Such a memorable visitation happened about 1850, in July. The following summer the planters in Prince's Bay, fearing a rep-

* That is, the fishes-as I understand it-not the witnesses ! 
etition of the onslanght, anchored shingles and pieces of waste tin on their. beds, scattering them at short intervals, in the hope that their dancing, glittering surfaces might act as "scarecrows" to frighten the fish away. Whether as an effect of this, or because of a general absence, no more drums appeared. In New York Bay, off Caven Point, where the old "Black Tom Reef" is now converted into an island, one planter of Keyport lost his whole summer's work, material and labor, in a single September week, through an attack by drums. A City Island planter reported to me a loss of $\$ 10,000$ in one season a few years ago; but the East River is about the northern limit of the drums, at least as a nuisance to oyster culture, so far as I can learn. The vexation of it is, too, that the drum does not seem to eat half of what he destroys; on the contrary, a great school of them will go over a bed, wantonly crushing hundreds of oysters and dropping them untasted, but in fragments, on the bottom.

In return, the drum is itself edible, though of rather poor quality. It is seen in market between July and October. According to tradition only ten species of fish were known to the Dutch when they discovered America. When they caught the shad they named it elft (eleventh); the bass twalft (twelfth); and the drum, dertienen (thirteenth). Our name, however, owes its origin to the strange, hollow, roaring noise the fish makes in the water, like the roll of a muffled drum.

When drums are absent, various other carnivorous fishes prey npon young oysters, such as the tautog, sheep's-head, toad-fish, meinbers of the cod family (when any of them get near a bed, which at present is seldom), and the skates. Of all this vermin the sting-ray or "stingaree" of the fishermen (including several sorts of Dybastes) is the chief. He is always present and steadily at work along the whole coast. Lying flat on the bottom, he works his triangular flippers until he lias washed away the sand from about the oyster he wishes to seize, if it is at all concealed, and then crushes it between his powerful jaws. Even clams do not escape. his sagacity in capture and strength of mastication, bat are devoured in great numbers. A dredge can hardly be hauled between New Jersey and Cape Cod without bringing up one or more of these enemies of the hardworking oysterman.

A small but numerous and persistent enemy of the oyster is the "drill" or "borer." Under this name is included, however, a numerous class of univalve mollusks, which are carnivorons in their tastes, and armed with a tongue-ribbon, so shaped and so well supplied with flinty. teeth that by means of it they can file a round hole through an oyster's 
shell. The mode in which it is done has been clearly described by the Rev. Samuel Lockwood, as follows:

"The tongue is set with three rows of teeth like a file; it is, in fact, a tongue-file, or dental band, and is called by conchologists the lingual ribbon.... With its fleshy disk, called the foot, it secures by adhesion a firm hold on the upper part of the oyster's shell. The dental ribbon is next bronght to a curve, and one point of this curve, on its convex side, is bronght to bear directly on the desired spot. At this point the teeth are set perpendicularly, and the curve, resting at this point as on a drill, is made to rotate one circle, or nearly so, when the rotation is re-

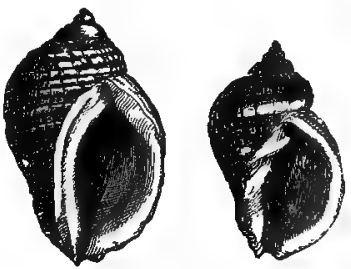

PURPURA LAPILLUS. versed; and so the movements are alternated, until, after long and patient

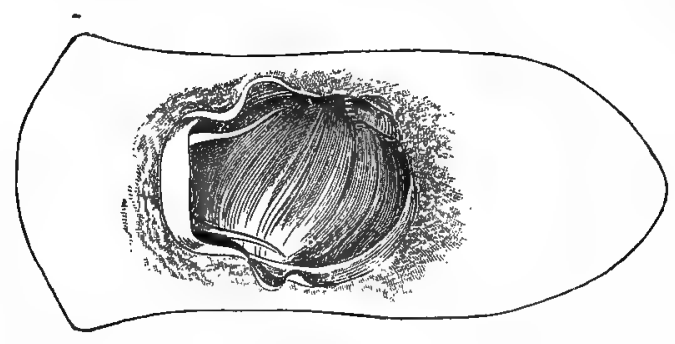

LUNATIA HEROS, WITH OUTLINE OF EXPANDED FOOT. labor, a perforation is accomplished. This alternating movement, I think, must act favorably on the teeth, tending to keep them sharp. To understand the precise movement, let the reader crook his foretinger, and, inserting the knuckle in the palm of the opposite hand, give to it, by the action of the wrist, the sort of rotation described. The hole thus effected by the drill is hardly so much as a line in diameter. It is very neatly conntersunk. The hole finished, the little burglar inserts its siphon or sucking-tube, and thus feeds upon the occupant of the house."

These small "snails," "drills," "borers," or "snail-bores," as they are variously called, belong to several species of Lunatia, Purpura, Anachis, Astyris, Tritia, Ilyanassx, etc.; but the master and most destructive, as well as most abundant of them all, is the Urosalpina cinerea of Stimpson, the

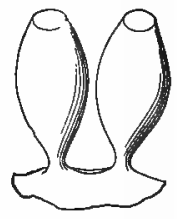

EGG - CAPSULES OF THE DRILL. common "drill" of the oyster-beds; and it is its eggs, laid in diminutive vase-shaped capsules, which are often found attached in groups to the under surfaces of stones. Several others of the small mollusks mentioned above attach eggs in a similar way, but the drill's capsules have very short stalks, or are almost sessile, and are compressed with an ovate ontline, while angular ridges pass down their sides. The natural home of the drill 
is the tide-pools and weedy borders of rocky shallows, where barnacles, hydroids, anemones, rock-loving limpets, and other associated forms that find shelter among the algæ, afford it abnndant food. Though this is precisely where the mussels (Mytilus and Modiola) grow till the rocks are almost black with them, it is said that they are never attacked by the drills-an immunity to which, no doubt, is due their extreme abundance in suitable situations.

The urosalpinx sometimes strays of his own will away from his native tide-rocks to the oyster-beds; but usually he is saved this tronble by being taken there with the small "seed" oysters in course of transplanting to new ground. Finding plenty ILYANASSA obsoleta.

of nourishment, he lives and increases rapidly enough to become in the cour'se of a few years a very serious obstacle to the planter's success by killing great numbers of the little oysters, for the old ones, having thick, hard shells, are rarely bored.

Once having attacked an oyster-bed, drills work with rapidity, and seem to make sudden and combined forays at considerable intervals. Their disappearance from certain restricted localities, too, for a long time, is unexplained. Eels are said to feed so greedily upon their eggs as almost to exterminate them in some waters.

Another serious cause of disquietude to the American oys-

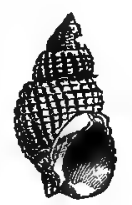

TRITIA TRIVITATA. ter-grower, especially in the Great South Bay of Long Island, is the fast-

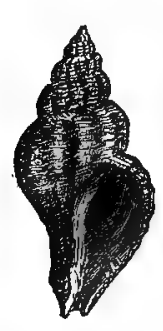

UROSALPINX CINEREA. ening of great quantities of young black mussels (Modiola plicatula) on the oyster-beds. This seems liable to occur also in the lower part of the East River, and at Staten Island. The mussels having established themselves grow rapidly, knit the oyster's together by their tongh threads, making culling very difficult, and take much of the food which otherwise would help fatten the more valuable shell-fish. On the Pacific coast Gastrochona, and various pholadiform mollusks are a great bane to the oyster-reefs, which they penetrate by digging burrows wherein their whole shell is lodged. Large numbers of these, with the help of boring-worms and sponges, may so riddle a reef as to cause its entire disintegration.

In Delaware Bay the spawn of squids, in the shape of clusters of egg-cases, appropriately called "sea-grapes," often gathers so thickly on the oysters during the inaction of summer, that when the fall winds come, or the beds are disturbed by a dredge, great quantities of oysters rise to the surface, buoyed by the inflated "grapes," and are floated away. 
Lastly, certain crabs are to be feared-chiefly the Callinectes hastatus, our blue, or soft-shelled crab, and the Cancer irroratus. Probably the

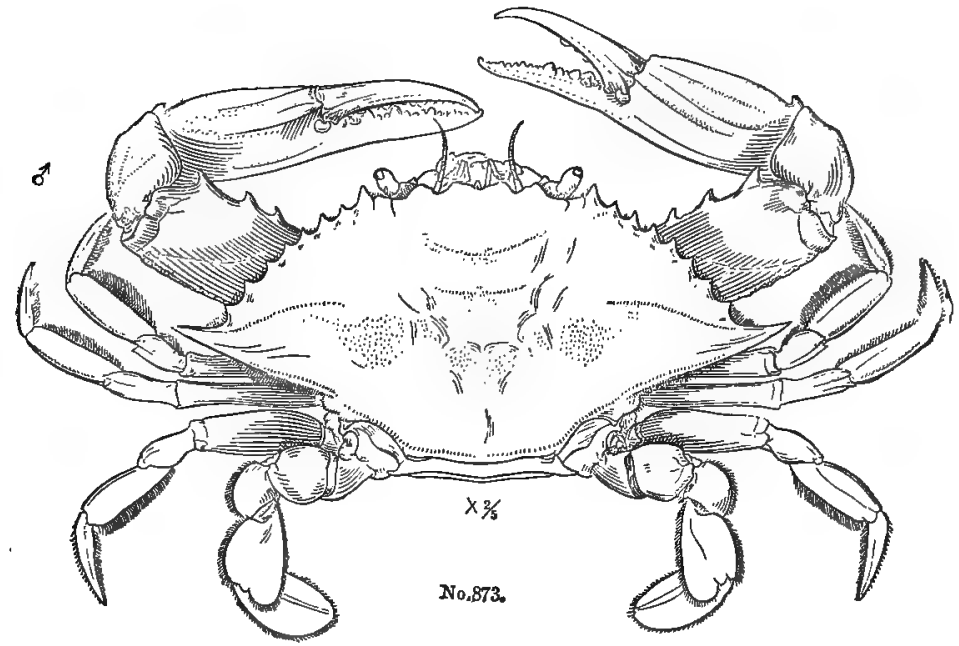

BLUE, OR SOFT-SHELLED CRAB-CALLINECTES HASTATUS.

latter is the more hurtful of the two. I have heard more complaint on this score at the western end of Great South Bay, Long Island, than anywhere else. They eat the small oysters, up to the size of a quarter dollar, chewing them all to bits: these are on the artificial beds, for they do

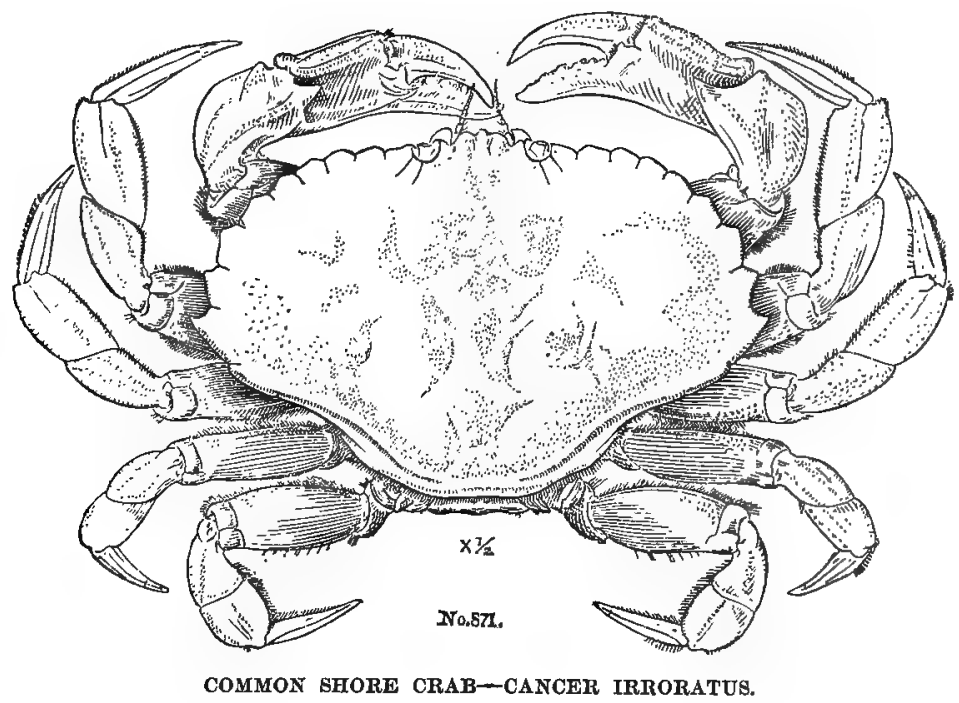


not seem to trouble the natural growth. Tolled by broken oysters, when the planter is working, they assemble in crowds. One man told me that he had had five hundred bushels of seed destroyed by these crabs within a week. While he was planting he conld see the pests, and thouglit they numbered one to every fifty oysters. A sinilar report comes from the Chesapeake Bay region. It is well known that in Europe crabs are very destructive to the planted beds, and it is quite possible that many mysterious losses may be charged to these rapacions and insidious robbers.

Aldrovandns, and others among the naturalists of the Middle Ages, entertained a singular notion relative to the crab and the oyster. They asserted that the sly crab, in order to obtain the flesh of the oyster, without danger to its own claws, watched its opportunity when the shell was open to advance without noise and cast a pebble between the valves, preventing their closing, and then extracted the animal in safety. "What craft," exclaims the credulons author, "in animals that are destitute of reason and voice!"*

* In respect to the little crab which becomes red in the cooked oyster, but is greenishbrown in life, opinion is divided as to whether its presence is of any harm to the oyster whose shells give it shelter, but the probability is that it is not. Its scientific name is Pinnotheres astreum, and it seems to be a parasite. It slips in and out of the oyster almost at pleasure, and enjoys a portion of all the good things the oyster feeds upon. We are told that it is the female alone which dwells in the oyster, and that males are almost never seen by the most careful searchers. Several allies inhabit various living mollusks, holothurians, etc. In the report of the Maryland Fish Commission for 1881, Professor J. A. Ryder gave some interesting particulars in respect to this little crab, which, from its nook in the oyster's gill-cavity, may be the means of indirectly supplying its host with a part of its food. Professor Ryder found attached to the crab a great number of compound colonies of the singular bell animalcule, Zoothamnium arbusculum, and that here and there numerous minute rod-like vibriones had affixed themselves by one end. "In this way it happens that there is a quadruple commensalism established, since we have the vibriones fixed and probably nourished from the stalks of the zoothamnium, while the latter is benefited by the stream of water drawn in by the cilia of the oyster, and the last feeds itself and its protégé, the crab, from the same food-bearing current. Possibly the crab inside the shell catches and swallows food which in its entire state could not be taken by the oyster; but in any event the small crumbs which would fall from the mouth and claws of the crab would be carried to the mouth of the oyster, so that nothing is wasted. We must consider the crab, with its forest of bell animalcules, in still another light. Since the animalcules are well fed in their strange position, it is but natural to suppose that they would propagate rapidly. They multiply in two ways, viz., by dividing both lengthwise and crosswise, one-half of the product being set free, and known swarmers. These cast-off germs of the animalcule colonies are no doubt hurried along in vortex created by the cilia of the gills and palps, carried to the mouth, and swallowed as part of the daily allowance of the food of the oyster. We are accordingly obliged to look upon the pinnotheres in this case as a veritable nursery, upon whose body animalcules are continually propagated and set free as part of the food-supply of the oyster, acting as host to the crab." 
In addition to these principal foes, many minor "vermin" must be contended with by the cnltivator of onr favorite bivalve.

The oyster-catcher, and other shore-birds, steal not a few mollusks at low tide. Barnacles, annelids, and masses of hydroid growth sometimes form about the shells, and intercept the nutriment of the mollusk, until it is nearly or quite starved; this is particularly true in southern waters. There are parasitic sponges also, which attach themselves to the oyster's shell and inmediately begin to penetrate its substance. One of these, Cliona sulphurea, is especially abundant along the middle Atlantic coast, and often pushes its small burrows quite through the shell, compelling the oyster to plng up the holes by extra layers of nacre on the inside.

Practically, however, sponges are of not much harm, while some fishermen assert that to have the "red-beard" or branching sponge, the graybeard (Sertularia argentea), and several other hydroids and bryozoa which pass under the general name of "scurf" and "yellow moss," appear plentifully on the beds, is a sure sign that the oysters are doing well; should an excess of these occur, however, they wonld both consume and tend to keep from entering its mouth a part of the mollusk's food-supply, and might also form eddies, acting as an impediment to catch drifting matter, weeds, and the like, until the mollusks were partially buried and smothered. In Narraganset Bay, a few years ago, oystermen were greatly troubled by multitudes of annelid worms (Serpuloe), whose tortuous cylindrical cases are formed thickly upon every shell, and serve to collect a coating of cases, sand, mud, etc., which is often half an inch or more thick. This is known locally as "sanding-up" or "loading," and under its infliction the mollusks deteriorate greatly in quality.

In addition to the active, animate enemies of the oyster, the beds suffer seriously, at certain times, from the elements, as has been pointed out in the preceding pages. Great storms will sweep the oysters all off the beds, bury them under shifting sand or mud, or heap upon them the drifting wrack torn from the shores. Beds which lie at the mouths of rivers are liable to be injured by floods also, which turn the water wholly fresh, or bring down enormous quantities of silt and floating matter, which settles and smothers the oysters.

To all these enemies and misfortunes cultivated oysters are more liable, and against them they are less defended than those growing upon the natural beds, following the law that a disturbance of nature's equilibrium is always to the advantage of the more powerful agencies present. 


\section{XIII.}

\section{THE HISTORY OF A MANGROVE KEY.}

THE immense abundance of oysters and oyster-reefs on the western 1 coast of Florida astonished the earliest explorers, and their histories of exploration contain many allusions to it. Charlevoix went along the reefs there two centuries ago, and writes in his "Voyages :"

"But this Coast is the Kingdom of Oysters, as the great Bank of Newfoundland, and the Gulph and the River St. Lawrence are that of the Cod-Fish. All these low Lands, which we coasted as near as possible, are bordered with Trees, to which are fastened a prodigious Quantity of little Oysters, of an exquisite Taste: Others, much larger and less dainty, are found in the Sea in such Numbers that they form Banks in it, which we take at first for Rocks on a Level with the Surface of the water."

The trees to which Charlevoix's men found oysters attached were mangroves, and the extent to which organic, living agents are adding to the coast-line of one portion of the United States is remarkable, the more so as we hardly expect results so large and substantial from any means short of volcanic or geologic methods. This truth has long been familiar to every one in reference to the coral islands, but it is not so generally recognized that another series of reef-islands livals these in importance and interest.

All along the western or Gulf coast of Florida, particularly at its southern end, are great numbers of bars of oysters, worthless (in their natural growth) for civilized humanity, but beloved of the raccoons which nightly come to eat them, and hence called "coon oysters." Many of these reefs go bare at low tide, and you may walk about on them. They consist of nothing but masses of oysters so crowded and cornpact that a solid and faily level surface crowns the whole reef, which may be several hundred yards long and forty or fifty yards in breadtl. You may count np the number of individual oysters when I tell you that a square foot will often contain a hundred.

When the reef has attained such a leight that its crest is exposed to 
the air at low tide longer than it is hidden by the water of the high tide, oysters will cease to grow at the centre, while still flourishing around the edges. The dead shells, becoming brittle, are soon broken to pieces by the waves-a work in which the breakers are aided by boring mollusks and worms, whose excavations cause large pieces of the consolidated reef to break off under every storm. These, tossed about in the water, are soon crushed, pulverized, and thrown upon the crest of the reef. The topmost growth of closely crowded slells, filled in with their wavecrushed fragments, speedily becomes cemented, by decomposition of some of the materials in the sea-water, into a compact deposit. Further action of the waves powders this into shell-sand (or, more properly speaking, into shell-dust), and produces the basis of a most fertile soil.

To this end, now that the solid reef stands fairly at or a little above the surface of the water, comes speedy and efficient help. Opposing the How of the currents, the old oyster-bar intercepts and furnishes lodgment to all sorts of drifting sea-wrack, receives a growth of the algæ and grasses which frequent half-submerged levels, and is all the time built up at the crest by the washing upon it of fragments broken from its edges. It is not long, therefore, before a sort of shelly soil is formed, weeds and herbage reach it by means of favoring winds or the droppings of birds, and finally some floating mangrove stem or seed takes root there, and manages to get so firm a foothold that the storms do not tear it away.

This done, the far-reaching and tangled roots of the bush form an eddy which deposits sand and floating stuff until more mangroves have room to root themselves, and the bar ceases to be a "reef :" it has become a "mangrove key."

Now the mangrove (of which there are several kinds) is a very curious tree, and one particularly well fitted for its circumstances. Its seeds germinate in the caly $\mathrm{x}$ of the flower, and, before they drop, grow to be little brown stems, six or seven inches long and about as thick as one's finger, with small rootlets at one end. Such mangrove seedlings float about all this coast and among the islands in such quantities that, as Professor Agassiz put it, one would suppose some vessel laden with Havana cigars had been wrecked there, and its precions cargo scattered in the ocean.

"In consequence of their shape, and the development of the root, one end is a little heavier than the other, so that they float meveuly, with the loaded end a little lower than the lighter one. When they are brought by the tide against such a cap of soil as I have described, they become stranded npon it by their heavier ends; the rootlets attach themselves 
slightly to the soil; the advancing and retreating waves move the little plant up and down until it works a hole in the sand, and having thus established itself more firmly_-steadied itself, as it were-it now stands upright."

The mangrove has a low, branching stem, and is thus pretty much all head; you cannot see anything as you approach but a compact mass of brightly green, thick, shining leaves, trailing to the ground. A nearer view discloses another very curious feature. From the main trunk, near the ground, extend out on all sides, and at varying height, some branches which do not go upward and bear leaves, but turn downward, enter the ground, and become roots. There are dozens of these stays surrounding every stem, and holding it, like so many cables, against the fury of the storms wbich sometimes hurl both wind and wares against the groves. But this is not all. Every low branch produces a considerable number of thick, leafless, straight twigs, which elongate straight downward through air and water until they penetrate the soil and become rooted. The mangrove is not only braced upon a score of roots, therefore, but anchored from every one of its lower and larger arms. A perfect tangle and network of these roots and rooted stems thus surrounds each tree and every islet with an abatis often several rods in width.

Such a net-work speédily verifies its likeness to a basket by catching outside matter. Along the solid edges of the key itself, and everywhere in the neighborhood, are living oysters which annually send forth a cloud of young to seek new quarter's. The mangrove stems afford capital resting-places, and, therefore, speedily become incased in infant oysters which increase in size and number very rapidly. This snspended kind is known as the "mangrove oyster ;" but I do not see that they are anything different from the progeny of the 'coon bars. Barnacles, too, in vast numbers, mussels, bryozoa, and forty forms of minute water animals cling to these half-submerged bianches or flourish under their shelter, where the hard sand and bare angles of oyster-rock are slowly buried beneath a coating of mud and decayed vegetation, which the basket-work of mangrove roots and salt-grass has caught and confined, so that henceforth it is in small danger of washing away.

An especially noteworthy nember of such a colony is a marine worm of small size, which forms about itself a tubular, twisted case of lime very like that of the Serpula. Along certain portions of the coast, south of Tampa Bay, these worms are extremely numerous; and they build up their cases so closely together that they join one another, and so cover the fonndation on which they grow with vertical calcareous tubes somewhat larger than a darning-needle. 
The richly impurpled apertures of these tubes (all of equal height) are separated from one another by the fraction of an inch; but they are cemented at their partly coiled bases, and the interstices speedily become clogged with sediment, forming a solid mass of lime. At high tide, when myriads of tentacles can be seen through the wonderfully clear Gulf water, protruding from the submerged and bristling surface, grappling industriously, but with feathery grace, for their microscopic food, this serpula colony becomes an animated and beatiful picture.

I suspect that these worms survive only one year, and then dying leave their indestructible cases to serve as the foundation upon which their progeny may rear a new tier of tubes. Thus, by the additions of successive generations (as in the case of the coral growth, but throngh a different history) this worm-structure increases into an extensive mass of heavy rock. I have seen pieces many yards square and two feet or more thick.

Growing irregularly, crannies afford a haunt for many species of mollusks and crustaceans that like to hide away in holes; and the mass is further enlarged by the growth upon it of bunches of oysters, and by the filling of the interstices with sand and broken shells which become solidified along with the worm-tubes through the production of a native cement. Thus millions of tons of limestone, most useful for building purposes, are each decade added to the Floridan coast by despised worms.

Attracted by the excellence of the hiding-places offered, and by the abundance of "small deer" lurking there, many predatory sorts of aqnatic animals come to the mangrove roots in search of food-conchs, whelks, boring sea-snails, crabs of several species, and mollusk-eating fish like the sheep's-head. Where there is teeming life, death must be frequent. Thousands of empty shells and fleshless skeletons sink into the animated ooze along the edge of the reef, and rapidily fill it up until the water no longer covers it, except at the highest tide, and then leaves behind an important toll of drift-wood, so that the adventurons, water-loving mangroves must push their roots farther and farther into the sea in order to find the best conditions for growth.

Meanwhile a similar process has been raising the centre of the island. Decay of grass and salt weeds, mangroves and drifted wood, finally lifts a surface permanently above the water. Huge flocks of water-birds daily alight upon it to rest and feed, and their droppings increase and enrich the soil. Various seeds are blown or floated from the main-land and contribute to its stock of vegetation; various land animals-chiefly reptilian -make the new key their home, die and are buried there. To the simple mangrove swamp thins succeeds an intermixture of oak, pine, and pal- 
metto, the rotting logs of which gradnally make a wide extent of solid and fertile ground.

Discovering this, Indians would get into the habit of landing there to open and feast upon oysters, clams, and conchs, and from the débris of these feasts would accumulate mounds or ridges hundreds of yards long and many feet in height. When the white man comes along he discovers the largest trees and most luxuriant nndergrowth upon these mounds of shells. Recognizing the excellence of the soil, it is there he places his house and plants his farm. The old oyster-bar becomes an

Now" "island" with a name on the nups.
Now the formation of keys just in this way has long been going on, and clusters of them abonnd all the way from Appalachicola to Key West. A group of mangrove islands, near such a coast as Florida's, acts like the interlacing roots on a single key; the currents are stopped, tides slackened, drifted matter and sand deposited, and great shoals, mud-flats, or sand-bars result. Given such an archipelagic condition, a straight sand-bar, or outer beach, is a natural sequence, and this, once formed, contributes still more to the shoaling of the channels inside, until they eventually become almost or quite obliterated, because many of the islands join together and finally unite with the main-land.

But, as I have said, this is wholly the work of animal life. Not until the oysters and their neighbors have really formed a "key" do the mangroves, with their train of aids, take up the work; and not until this

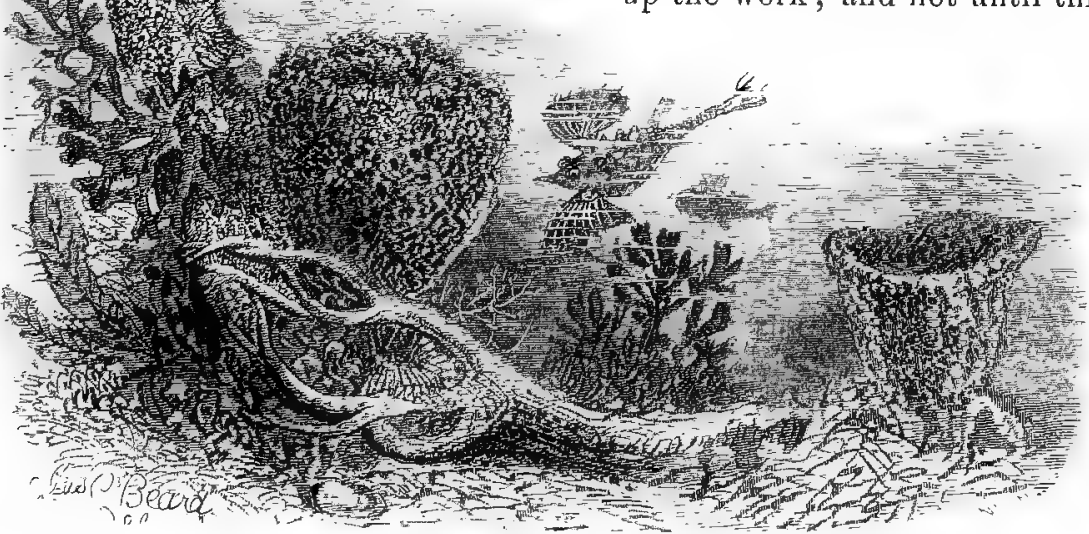

AT THE MAIGIN OF A MANGROVE KEY, 
has long proceeded does the drifting of sediment down the rivers, or the washing up of bottom-sand by the unter waves, increase the bulk of the islands that soon add theil well-prepared areas to the general coast.

[NoTE. - The reader may find published in one of the memoirs of the Museum of Comparative Zoölogy at Cambridge, Massachusetts, a still more complete presentation of this subject, chiefly, however, from the point of view of the student of corals. The author is Mr. Alexander Agassiz, who adds to his father's writings on the subject much learning of his own, and illustrates the whole by a series of magnificent pictures of Floridan corals. The memoir to which I refer is No. 1, of volume viii., and is entitled, "Report on the Florida Reefs by Louis Agassiz, accompanied by Illustrations of Florida Corals, etc." It is a quarto of sixty-one pages, with twenty-three plates, and was published in 1880.]

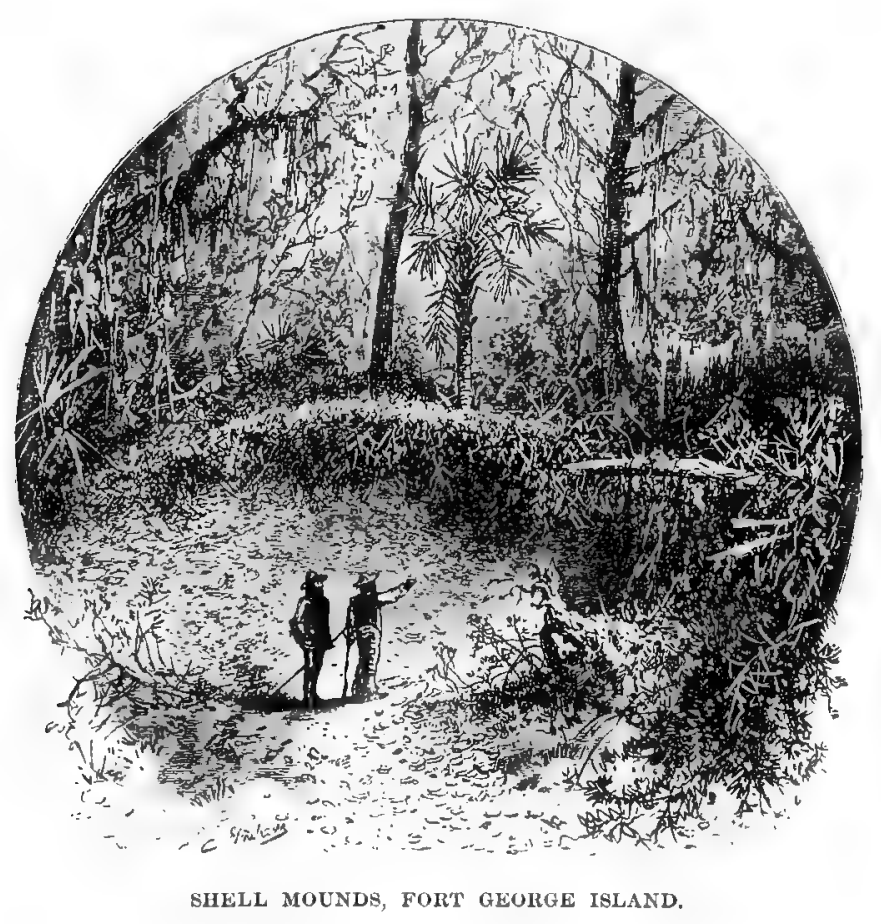




\section{XIV.}

THE POMPANO-SHELLS.

B IG SARASOTA is an island on the Gulf coast of lower Florida, which began its history as an oyster bar and mangrove key in the way described in the last chapter.

Walking along the seaward verge of this island one January morning, while a stiff sou'-wester was charging the gleaming beach with whole squadrons of "white horses," I noticed everywhere tiny holes, like pinpricks, in the wet, white shell-sand displayed at low tide. These pinholes, I knew, must indicate that a mollusk was buried under each one of them, but of what sort I did not at first ascertain.

I also noticed that the waves seemed to be casting up great numbers of live wedge-shells, or pompano-shells, to which conchologists give the name Donax variabilis. They are extremely pretty little mollusks, doublevalved like the mussel, always less than an inch long (at least this species), nearly square-cut at one end, but well tapering at the other, and marked in bright colors after the most exquisite patterns. The ground tint is generally white, but it may be bluish or greenish or pink, straw - color, salmon, saffron, or chocolate. The surface of the shell is finely ridged in delicate lines radiating from the little knobs or beaks at the hinge on the "back" of the shell to the margin, where each ridge ends in a minute tooth. The teeth of each valve half shut past one another when the shell is closed, so as to interlock and become perfectly tight all round, with the exception of a breathing crevice at the blunt end. Moreover, above the ground shade and delicate sculpturing of the shell are laid broadening, ray-like dashes of color spreading outward from the beaks; or, if these are wanting, ornamental bands run lengthwise, parallel with the margin, so as to be concentric, while in some gaudy specimens both styles of marking prevail.

A student of decoration might study with profit the striking arrangements of colors which these markings show. How do you like the idea of soft canary-color overlaid with a narrow stripe or two of Van 
Dyke brown? or white, blending into pink at one end, and touched with broad lines of saffron? or the most delicate of cherry red, fading away into pale, brownish straw-color? or a dozen tints of blue, curving side by side in soft flounces over the rounded space of half an inch? Yet these, and a hundred other lovely, unthought-of patterns, were worn by these pygmy belles of the beach, and no one of them all could complain that another had initated her; nor did the plainly dressed seem any the less happy.

Attracted at first by their handsome jackets, as so often happens with onr country cousins of a larger growth, I became interested to know their manner of life. As each wave carne rushing in, carrying everything before it, the wedges would go up the beach with the rest of the shells, coral, moss, sponges, and sea-wrack; but when the surf had broken, and the great law of weight pulled the waters back, sucking the sand and light stuff down into the sea again, I noticed that every little donax would stand up on his sharp end as quick as scat! and dig for dear life into the wet, yielding sand just being started downward by the undertow.

Once in a while the current would prove too much for him, but nine times out of ten he would sink the most of his length in the sand, and hold his place till the waters had swept on. It was very amusing to watch a hundred or two of these brightly painted little fellows, all at one signal, as it were, flop up on their points and wriggle themselves with the utmost energy deep into the sand, which sometimes would drift away from around them so fast (loosened by theil penetration) that they had to go down three or four times their own length before making an anchorage. These mishaps reminded me of the frantic exertions I once witnessed in New Mexico on the part of a lizard, which was chasing a bowlder rolling downhill in a vain attempt to re-hide under its shelter.

But I soon perceived that these active wedges-hundreds thongh there were-represented only the unfortunates that had been washed out of their burrows by the heavy surf, and that their notion of happiness was to be buried and thus protected as long as possible from the tumult of the waves above. That these were the dwellers beneath the thousands of mysterious "pin-holes" I have mentioned was at once suggested, and quickly proved by digging them np.

Washing the earth away, they all lay in my palm tightly closed and perfectly still. But I knew there was something inside of their pretty coats, so I took them on board my yacht, partly filled a basin with sand and sea-water, and turned my prisoner's loose.

There had elapsed an hour, I fancy, between taking them up and 


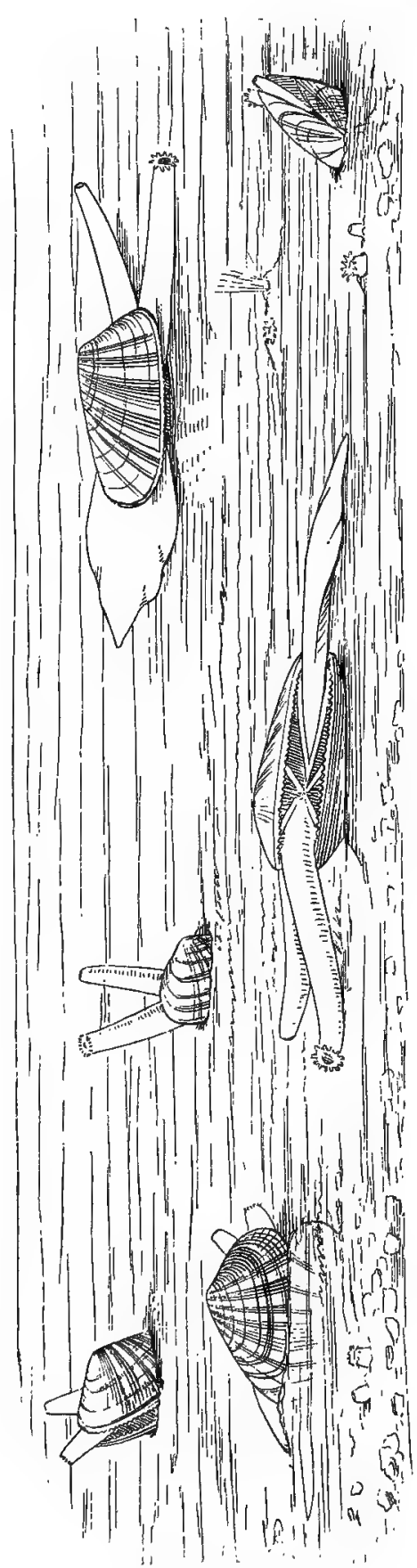

putting them into my improvised aquarium, and the captive donaces were just a trifle thirsty. It did not take them ten seconds-so quickwitted are they-to learn that they were at home again; and ten seconds later every man-jack of them was doing his very best to hide. But this was precisely what I did not want, and had guarded against, by giving them too little sand to cover themselves. Soon discovering this state of affairs, the most of them gracefully gave np trying, and began to open their shells where they were, with what Mr. Darwin would term a fine "adaptation to environment."

Now, if you carefully open a donax (or any similar bivalved mollusk) you find just underneath the shell a thin-fringed membrane or skin, which clings to the inside of the shell; this is the "mantle" of the animal, covering hiın like an undergarment. Lifting this, you will perceive two thinner and shorter membranes-the gills of one side-and underneath them a sack which contains the heart and digestive organs. Below this sackthat is, opposite the hinge-is a thick, yellowish, tough portion, called the "foot," not because it is formed in the least like the foot of a quadruped, but becanse it serves the same purpose of locomotion. This "foot" is the hinder part of the animal, and in the thin end of the wedge; you cannot speak of it as at the tail, for bivalved mollusks have no head! Within the thick, blunt, anterior end of the 
shell, where the "lhead" might be expected, you will notice, as you carefully dissect your donax, that there are two little pointed knobs protruding from under the mantle.

I knew what these were, as well as I knew the use of the "foot," but I was astonished to see how much there was of both of them when I had put my captives into the basin. Out from the sharp end of each little wedge slid a thin, flexible, three-cornered bit of flesh, like a knife-blade, with crinkled, waving edges, the point of which was thrust into the sand, twisted a trifle to catch hold, and then suddenly contracted, drawing the mollnsk down nntil the point of his shell was out of sight. Repeating the operation far more rapidly than I can write abont it, he made his way, foot-first, straight down into the sand as fast as he conld have walked across it-faster, indeed, for he cannot walk at all except by burying the edge of his top-heavy armor deep enough in the earth to maintain an upright attitude. It was entertaining to see how, in my crowded aquarium, a little fellow would stretch his flexible spade until it was longer and broader than his whole shell, and how he would feel about with the sharp, unuscular tip, stirring up the sand until he struck an ensy place to enter; or, with its aid, would creep awkwardly about among his companions, who always took his rough elbowing good-naturedly.

But the donax cares to go only deep enongh in the sand to be well hidden while he is feeding. Sinking down backward, he thrusts up through the opened blunt end of his shell the knobs which we noticed there in our dissection, now stretched forth into two pipes, with which he can leach out to a distance almost twice the length of his shell. Throngli one of these pipes he sucks in a constant stream of sea-water, which bears him his minute food; and throngh the other pipe is carried away the waste water after his stomach has taken up all the food that it brought.

Very pretty was it to lean close over that basin of water and see those dozens of pairs of slender tubes, of all lengths, from nothing, hardly, to an inch and a half, looking almost as white and clear as if made of glass -and far more lovely - elongating and retracting, waving abont with slow, graceful motions, or gently nodding together as if they enjoyed each other's society. And the more closely one observed the white, silky tubes, the mol'e beautiful they appeared. Each lower tube bears at its" end a crown or fringe which resembles the frost-leaves on a window-pane as much as anything I can think of, or it is like a circle of snowy spruceboughs all pointing inward.

This little fringe is vely easily moved by means of the gossamer 
threads of nerves and muscles which, if you have a magnifying glass, you can trace running up and down the walls of the transparent tube; and its use is to act as a screen. You can prove this very plainly if you let a donax bury his shell as he likes to do. A moment later you will see a small white head pushed just above the surface, and this beautiful feathery circlet opening and shutting, throwing aside the shining grains of sand that float upon it, or clutching with eager grasp some soft morsel and passing it within. At the same time, close beside it, protrudes very slightly from the sand another tube-head, but here there is only a ragged edge instead of lovely fringes; and out of this tube bubbles up a perfect little fountain of waste water, tossing forcibly aside any floating stuff that comes opposite its aperture.

One of the most striking things about our wedge-shaped pet is his strength. That soft, thin foot has such power that with it he can nearly stand upright, and can dig swiftly through the most compact sand. He can force a stream of water out of his hose-pipe which will plough up the bottom; and, by means of his small internal muscles, can hold his shellcoat so tightly buttoned that only with the greatest difficulty can my giant-fingers pull it asunder.

When the sun goes down, or when the water gets cold, the donaces, like sensible little men, take in food-tubes and digging tools, and shut their shells for rest.

The coast fishermen here call these mollusks pompano-shells, because, they say, they form the only food of that fish. The pompano has the reputation of being the very finest fish for the table that swims in southern waters; and if this splendid reputation is well deserved, and is due to his living upon our little mollusks, surely the donax is worth all the admiration we have given it. 


\section{XV.}

\section{A PRACTICAL VIEW OF DEVIL-FISHES.}

$r$ THE large class of mollusks called cuttle-fishes or devil-fishes bears 1 very important relations to our fisheries, and, consequently, to the food-supply of the United States. Some of these cuttle-fishes attain huge bulk and corresponding abilities for destruction. The two species of Architeuthis, roaming through the North Atlantic, have each a total length of from thirty to fifty feet, and a weight of solid flesh amounting to thousands of pounds.

"The cuttles," says Dr. Philip Carpenter, "have very acute senses. They have an approach to a brain enclosed in a cartilaginous skull. They can hear sounds, and evidently enjoy the taste of their food. They have a large fleshy tongue, armed with recurved prickles like that of the lion. They either crawl on their heads tail upwards, or swim, tail foremost, striking with their arms, or squirt themselves backward by forcing water forward throngh their breathing funnels.

"They are ferocious creatures, the tyrants of the lower orders, and do not scruple to attack and devour even fishes. The larger kinds are deservedly dreaded by man. Their weapons consist in their powerful arms, which are abundantly furnished with rows of cup-like suckers, each of which fastens on its prey or its foe like a limpet to the rock. Often these are accompanied with sharp curved teeth, strong enough to be preserved even in fossil species."

The giant cuttle-fishes of the North (Architeuthis), and the commoner squids and calamaries of our Atlantic coast, belong to the armed division of the order termed decapods. The three smaller species ordinarily met with are Loligo pealei, Loligo pallida, and Ommastrephes illecebrosa; on the extreme southern coast they are replaced by an octopod (Octopus granulatus).

Of these four, Loligo pealei is the common squid from Massachusetts to South Carolina. When full-grown (which seems to be only after several years) it is more than a foot in length. The color, when living, is 
very changeable, owing to the alternate contractions of the color-vesicles or spots, but red and brown predominate, so as to give a general purplishbrown color: In early summer this squid resorts to gravelly and weedy bottoms to lay its eggs. They are contained in bunches or clusters, sometimes six or eight inches in diameter, consisting of hundreds of gelatinous capsules, each holding numerous eggs. These clusters are attached to some fixed object, like the oysters npon planted beds. This last occurrence seems to be a source of decided harm in Delaware Bay, for the oystermen there assert that the larger "seagrapes" (as they call the eggbunches) lift many oyster's from the bottom by their buoyancy, and float them off in stormy weather.

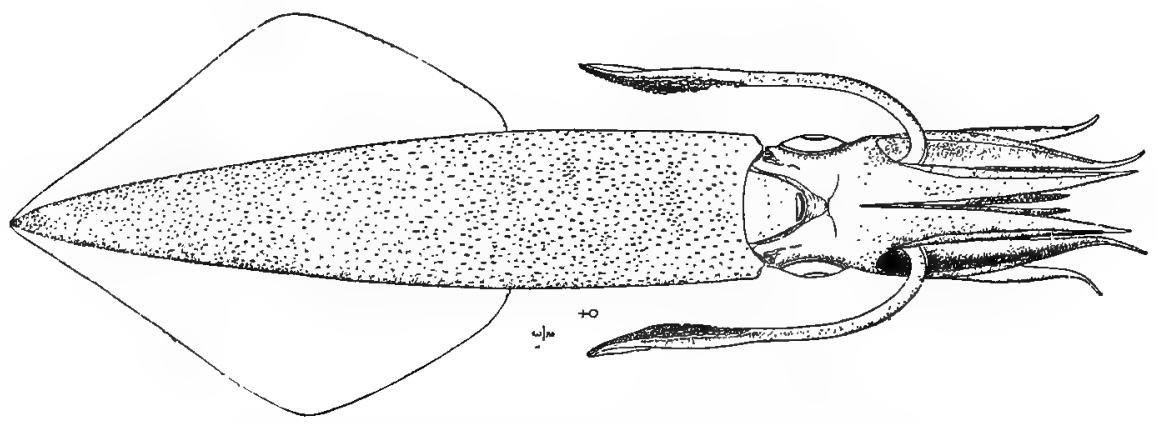

UNDER SURFACE OF THE COMMON SQUID-LOLIGO PEALEI.

North of Cape Cod the "squid" is represented by the sea-arrow or flying calamary (Ommastrephes illecebrosa), sometimes called "short-finned" in contrast to the "long-finned" characteristic of the loligos, which they resemble in size and color.

All of these squids, big and little, are great enemies to fishes, attacking any species small enough to be defenceless. The menhaden and mackerel seem to suffer chiefly, and Professor Verrill has described the operation in a graphic way:

"In attacking the mackerel they wonld suddenly dart backward among the fish with the velocity of an arrow, and as suddenly turn obliquely to the right and left and seize a fish, which was almost instantly killed by a bite in the back of the neck with the slarp beaks. The bite was always made in the same place, cutting out a triangular piece of flesh, and was deep enough to penetrate to the spinal cord. The attacks were not always suecessful, and were sometimes repeated a dozen times before one of these active and wary fishes could be caught. Sometimes, after making several unsuccessful attempts, one of the squids would suddenly drop to 
the bottom, and resting upon the sand would change its color to that of sand so perfectly as to be almost invisible. In this way it would wait until the fishes came back, and when they were swimming close to or over the ambuscade, the squid, by a sudden dart, would be pretty sure to secure a fish. Ordinarily, when swimming, they were thickly spotted with red and brown, but when darting among the mackerel they appeared translucent and pale. The mackerel, however, seemed to have learned that the shallow water is the safest place for them, and would hug the shore as closely as possible, so that in pursuing them many of the squids became stranded and perished by hundreds, for when they once touch the shore they begin to pump water from their siphons with great energy, and this usually forces them farther and farther up the beach. At such times they often discharge their ink in large quantities. The attacks on the young mackerel were observed mostly at or near high-water, for at other times the mackerel were seldom seen, though the squids were seen swimming about at all hours; and these attacks were observed both in the day and evening. But it is probable, from various observations, that this and the other species of squids are partially nocturnal in their habits, or at least are more active in the night than in the day. Those that are canght in the pounds and weirs mostly enter in the night, and evidently when swimming along the shores in schools. They are often found in the morning stranded on the beaches in immense numbers, especially when there is a full moon, and it is thought by many of the fishermen that this is because, like many other nocturnal animals, they have the habit of turning towards and gazing at a bright light, and, since they swim backward, they get ashore on the beaches opposite the position of the moon."

The loss sustained by the fisheries through their voracity is probably equalized by the food which cuttle-fishes furnish to the carnivorous fishes and various other denizens of the deep. For example, the sperm-whale seems to rely largely upon a diet of squids, sinking to the bottom where they are groping about to drag them up, or nipping off their long arms as they swim abont nearer the surface. Dolphins and porpoises also prey upon the cuttles, and all the flesh-eating fishes pursue and devour them at every opportunity, particularly the cod and bluetish.

Knowledge of this fact long ago led to the squid being taken by fishermen as an attractive bait. More than half of all the Bank fishing is said to be done with such bait. When the shoals of this mollusk (Loligo squid) approach the coast, hundreds of vessels are ready to capture them, forming an extensive cuttle-fishery, engaging five hundred sail of French, 


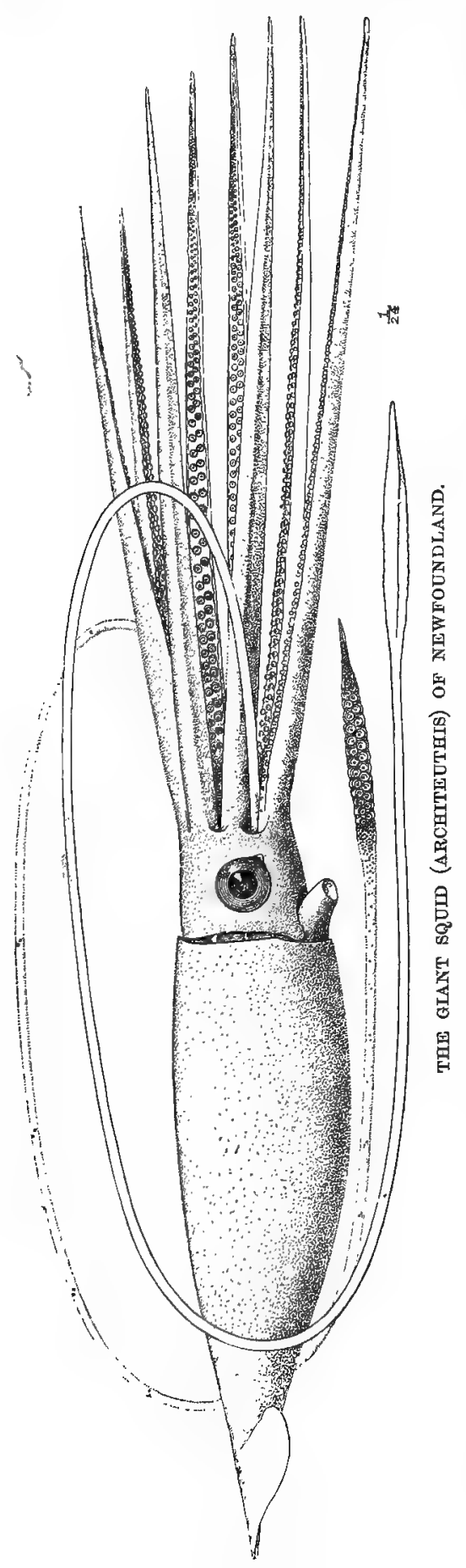

English, and American ships. Their habit of moon-gazing, also, is sometimes taken advantage of by the fishermen on the coast of Maine, who capture them as bait for codfish; they go out on dark niglits with torches in their boats, and by advancing slowly towards a beach drive them ashore. Violent sturms heap great windrows of dead squids on the beach, where they are gathered up; and they are also sometimes taken on lines adhering to the bait set for fishes. These drives and accidents happen in the spring when the cuttles are flocking into shallow water to lay their eggs.

Since this solidly-fleshed animal is so extensively eaten by other animals it is not surprising that men also should number it among the edible products of the sea. "The flesh of the large cephalopodous animals," says Simmonds, "was esteemed as a delicacy by the ancients. Most of the Eastern natives and those of the Polynesian Islands partake of it and relish it as food. They are exposed for sale, dried, in the bazaars or markets throughout India, and dried cuttle-fish may be seen among the articles of Chinese, Japanese, and Siamese food. In Chili the flesh is also considered a delicacy, and in Barbados the bas: tard cuttle-fish or calnar (Loligo sagittata, Lam.) is used as an article of food by the lower classes."

In the Mediterranean, also, particularly near Tunis and along the 
Portugal coast, the catch and consumption of cuttles is large, amounting to nearly a million pounds a year, most of which is sold in Greece after being salted and dried or pickled.

Cephalopods are largely used by the inhabitants of the shores of the Adriatic, being eaten by all classes of the population, thongh despised even by the poorest in the north of Europe. They are generally captured by means of pronged spears, occasionally in nets, and not unfrequently in the basket-traps set for other fish. The common squid (Loligo vilgaris) is the most valued of all as an article of food, the average annual catch amounting to no less than six hundred tons, valned at $£ 12,000$. The flesh is fried in oil, and is described as sweetish, but as hard as leather. It is indigestible, even in the best of seasons; yet, to judge by the high price it realizes, it inust be a favorite with the richer classes.

A writer in the London Field recently described the amusing scenes witnessed at the fish-market of an ont-of-the-way port of southern Italy, and gives a paragraph to our subject which is worth quoting:

"In one of the tubs were cuttle-fish, really beautiful in their transpareney, floating gently on the surface. The other tubs were filled with octopus, lively and full grown, their long arms feeling tenderly over the sides, some writhing horribly, and others qnietly reposing, their arms coiled at their sides, exposing the dread suckers in every fold, the body in shape and color resembling a large, rongh eocoanut, with evil, protrud. ing, observant eyes, looking straight to the front, at the same time vigorously discharging water from the pair of blow-pipes like a steam-pump during their short and quick respirations. When a purchaser arrives and makes a selection, the vendor adroitly seizes the fish by the back of the neck, the arms twisting and extending in all directions; it is dropped into the scales, and, if approved of, the salesman gives it a twist, almost turning it inside out, killing or disabling it in a moment. The octopus is eaten with gusto in southern Italy; but to see a mess of chopped fullgrown octopus served with tomato sance is really trying. When very sinall the octopus is used as a garnish for fish, and when fried crisp it might be mistaken for macaroni. The octopus has a strong beak, like a parrot, and is especially fond of crabs. It is often canght by tying crabs to a string and dropping them on the clear gravel bottom, where they are quickly seized by the octopns, who holds on steadily; meanwhile he is quietly drawn into the boat."

One sort of enttle (Octopus punctatus) serves the double purpose on our Pacific coast of 'bait for the fisheries and food for the Indians. For' the latter purpose it is chiefly sought in Pnget Sound, where the coast 
tribes hunt and kill octopods, often large enough to be dangerous foes in a quarrel, by going to their hannts in canoes and spearing thein. To some small tribes the octopus affords the chief supply of animal food.

There is no reason why squid flesh from the North Atlantic Ocean shonld not become available as food, and prove desirable to those who like it. It would be both wholesome and cheap, and a single architeuthis would furnish a meal for a frigate's crew. In Bermuda the Octopus granulatus regularly forms a portion of the fare of the fisher-families; and as Bermudan fish wander across to the Florida reefs, no doubt this habit prevails there also. In New York City there is a considerable sale of fresh squids to foreign residents, and this trade is increasing.

In addition to its value as bait, a source of oil (our Ommastrephes has been thus utilized), and as a possible food, the ceplualopods contribute two or three useful articles to commerce. A large portion of them carry under the skin of the back a long, flat, calcareous "bone" or plate, which serves as a stay or support to the frame in lieu of a skeleton. In some species it is slender, like a quill pen. This bone reduced to powder forms a useful ponnce, "used in rewriting over erasures to prevent blotting, and in medicine is an antacid." It is also combined into a dentifrice; and is fed to caged birds. For this latter purpose many thousands of pounds of cuttle-bone are brought into the United States every year, furnished chiefIy from China, but also collected floating in the Mediterranean. None of our American species afford a useful cuttle-bone, however, so that this import can scarcely be diminished. The name calamary is often applied to a cuttle-fish, and arises from the fact that each of them carries in an internal gland a supply of blne-black, ink-like liquid, which, npon the slightest alarm, he discharges into the water, making a dense cloud, under cover of which he rapidly retreats.

This ink, removed and dried into little cakes, with a greater or less adulteration, forms the sepia of painters and the Indian-ink of dranghtsmen. At present it is brought almost wholly from Oriental ports, but it might probably be procured on our coast as well. Provided with pen and ink on all occasions, these mollusks seem truly to stand at the head of the class of animals they represent, not wholly because of their superior size and loftier brain, but also on the score of literary accomplishments.

There are frightful tales abroad of the ferocity with which the larger of these creatures will attack man, and they are greatly dreaded by the shell-divers of the South Seas; but the truth is, the enttle-fish is timid, and will hide or run away whenever he can from anything so large and strange as a man-that is, any cuttles smaller than the giants of New- 
fonndland. A diver who tonched a large octopus monla instinctively be seized, of course, since the erenture would know no different course of action-but voluntary attack is not credited by those who know most about the habits of the animal.

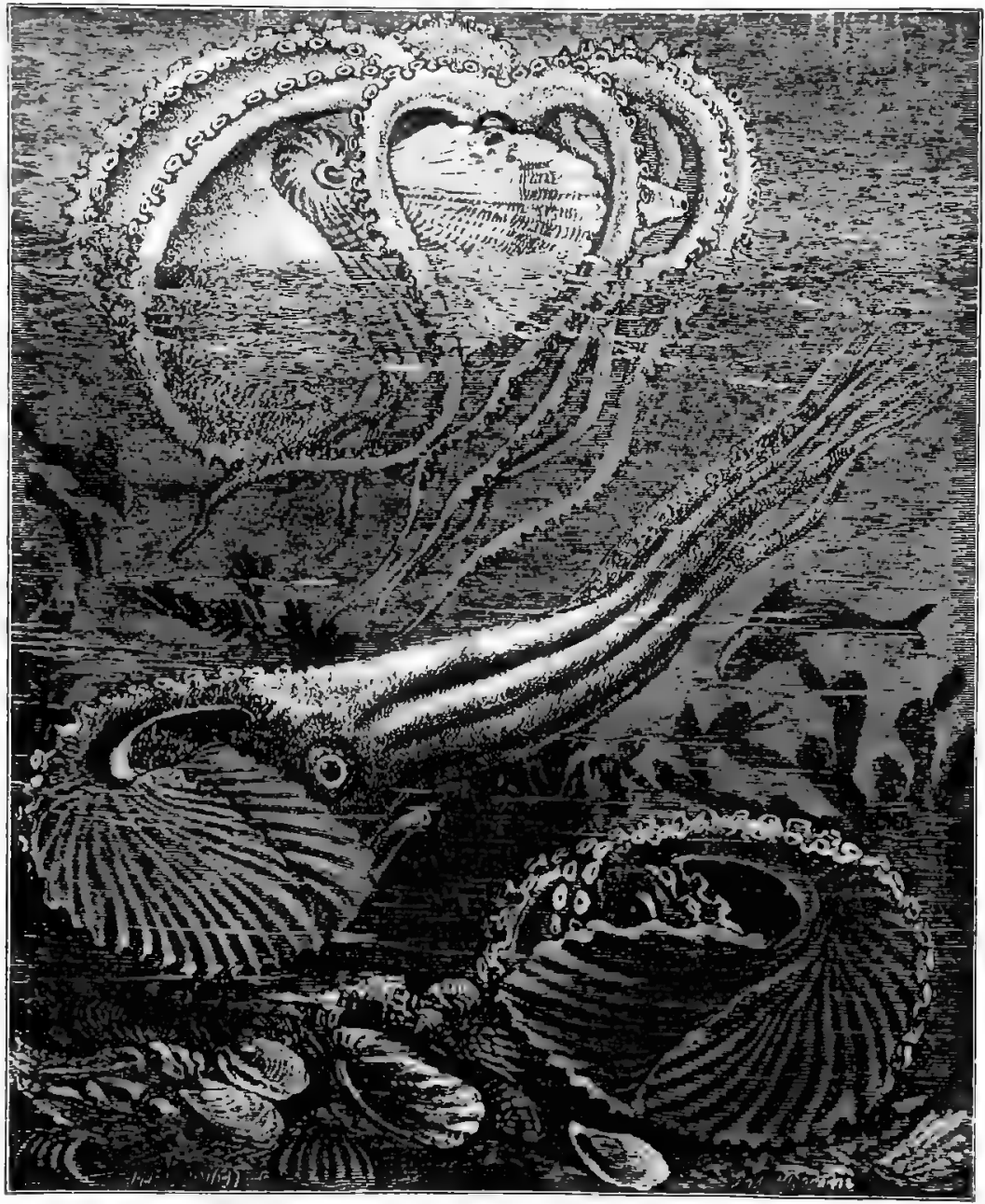

THE ARGONAUT CUTTLE, OR PAPER NAUTILUS, 


\section{XVI.}

\section{ELK ANTLERS.}

WHEN one learns for the first time that the enormous, spreading antlers worn by the males of the deer tribe are the product of a single season's growth, and are thrown away to be renewed every twelvemonth, it seems wholly incredible; but it is easy to explain, so that any one may readily understand how it is possible. Let us take, as an example, the broad head-gear of the elk, or wapiti of our north-west. He has the greatest antlers of any of our deer, except, perhaps, the inoose, whose horns may sometimes be heavier.

The elk stands as high as a medium-sized horse, to which it bears a general resemblance, but it has the shapely head, prolonged, naked nose, upright neck, trim shoulders, straight, slender body, muscular hams, and short tail characteristic of the deer tribe. The ears are rather short, pointed and mobile; the eyes deep blue. The hair in summer is a rich brown color, darkest on the neck, where it is almost heavy enongh to be called a mane, and yellowish brown or nearly white on the throat, breast, and inside of the legs. As winter approaches the brown hair is shed, and a denser growth appears, which hunters call his "blue coat."

Elks are born in May and early Jume in some dense grove beside a mountain stream, where the mother or cow-elk has hidden herself away from the little herd of her companions. Going one day through an aspen grove in the Seminole range, a spur of the Rocky Mountains, our party roused an elk, which dashed away just in time to save its life from our bullets and send us to bed that night withont fresh venison. We camped close by, and after tea, while walking about the grove, stumbled upon a little calf-baby elks are not called "fawns"-and carried it to our fire, squealing lustily, where we tied it to a tent-pin. This calf's hair was of a bright chestnut-brown color'; its sides were marked with irregular lines of round white spots, which would disappear at the first shedding of hair.

Probably every copse along the foot of these monntains was the scene of a similar retirement of mother and little one. When a fortnight old 


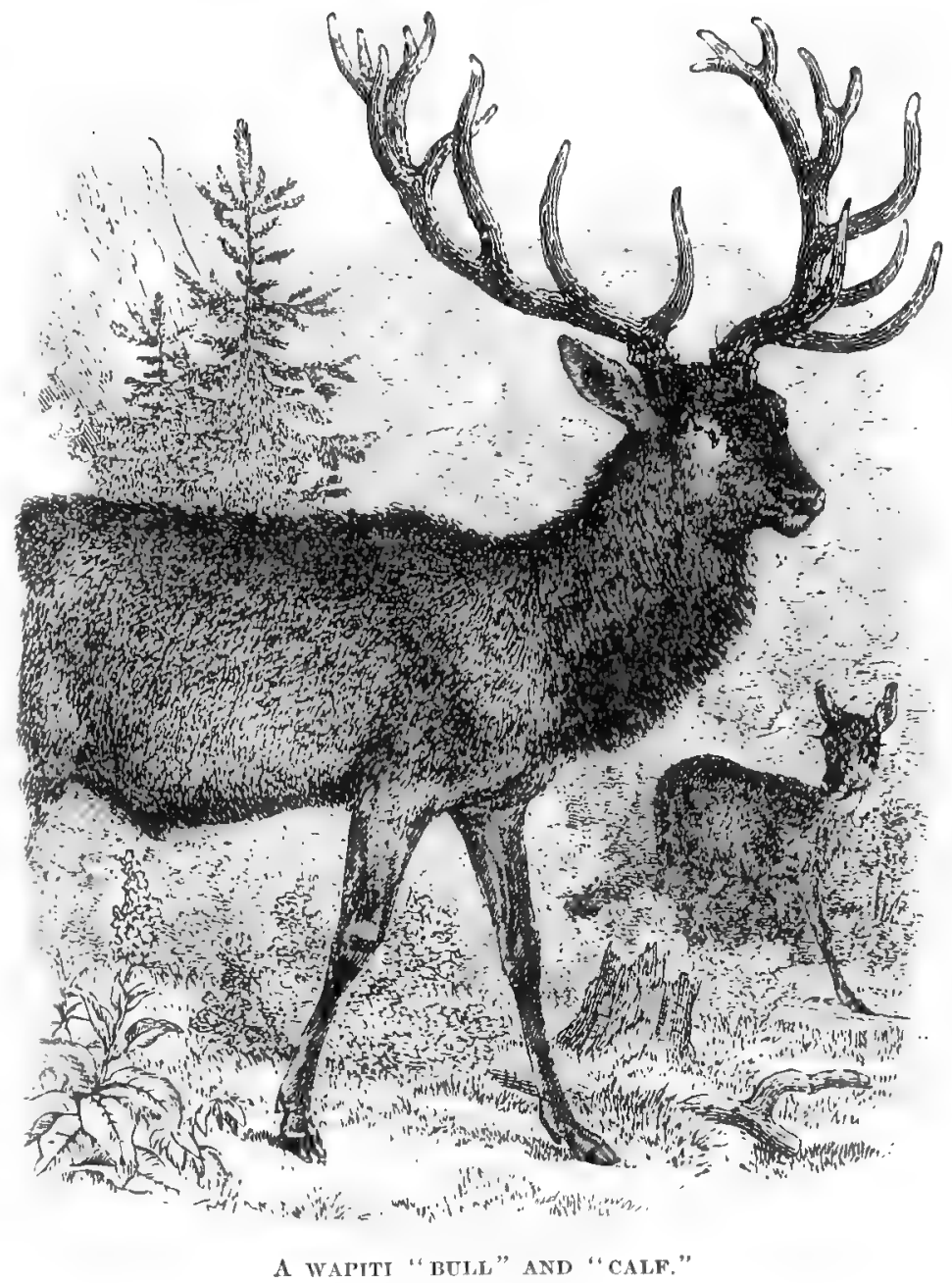

(Stuwing the bulk of the antlers as compared with the size of the head.)

the calves are able to travel, and then, with their mothers, join little companies of cows and yearlings which rom alout the plains and hills where pasturage is good and insects are not too troublesome. Until able to care for themselves (so say the hnnters) the calves emit no scent, and it is therefore only by chance that a cat or panther conld find or destroy one. They grow rapidly to be strong and fleet.

During all this time of the babyhood of the youngsters their fathers, the "bull ellis," have also isolited themselves, and, in some quict spot in 
the woods, or among the willows growing densely along all western streams, are awaiting the growth of their horns. About the time of the shedding of the winter coat, in earliest spring, the elk finds his antlers uneasy upon his head, and begins to rub them against trees until they fall off. You meet with discarded horns all over the mountainous West, and formerly they were so abundant that the Indians heaped them into lofty monuments.

His antlers gone, the buck feels like Samson after the clipping of his hair. He is afraid to meet other bucks, against whom he can no longer oppose equal weapons. He is shy of the does, to whose favor his splendid antlers had once commended him; so he secludes himself in some retired spot, and for five or six months waits for his strength and beauty to be restored to him in a new set of horns. During this time he makes as little exertion as possible in securing the various weeds and grasses which form hir food, and moves but short distances from his lair.

No donbt he feels sick and indolent, for all vitality is concentrated upon the building of antlers. Over the knob on the sknll, which is the pedestal of the horn, spreads a thick skin, furred on the outside with a coat of short brown hairs. This skin is porous with vessels bringing blood and the calcareous materials out of which horn is constructed, which ooze through the inner layer of this skin, and are deposited in the form of spongy tissues that become harder and harder, and are surrounded by a wall of denser structure. As fast as the deposits are made, the soft skin, aptly called the "relvet," enlarges and extends itself, acting as a scaffolding upon which the workmen, Blood and Company, can stand as they put this bit of tissue and that bit of ivory in its place. At the proper point prongs are made to diverge and continue their growth, while at the same time the building of the beam of the horn proceeds. So the antlers are erected by deposits sent from the velvet through all the spongy mass of new horn, which feels warm to the touch, and is so soft that you may bend it, or carve it with a penknife.

In some parts of the world these growing horns, while still "in the velvet" and surcharged with blood and nutriment, become a delicacy among foods. There is a regnlar trade in edible reindeer horns from Siberia and Lapland into China. The half savage owner of the herds puts to some ntility every scrap of the reindeer's body except its antlers. This exception the Chinaman greatly wonders at. He is of the opinion that no finer jelly exists than can be made by boiling down these succulent horns. Buying the antlers in large quantities, the border traders dry them thoroughly, and send them to all parts of the empire, and to the 
home-minded Celestials abroad. I have seen scores of dried antlers attracting envious eyes in the markets of the Chinese quarter of San Francisco. Our American Indians also eat young deer-horns, the Sionx and neighboring mountain tribes devouring them raw with great gusto. There is no reason why civilized cookery might not avail itself of this new comestible to advantage. Its rarity, to say the least, would recommend it as a tidbit on great occasions.

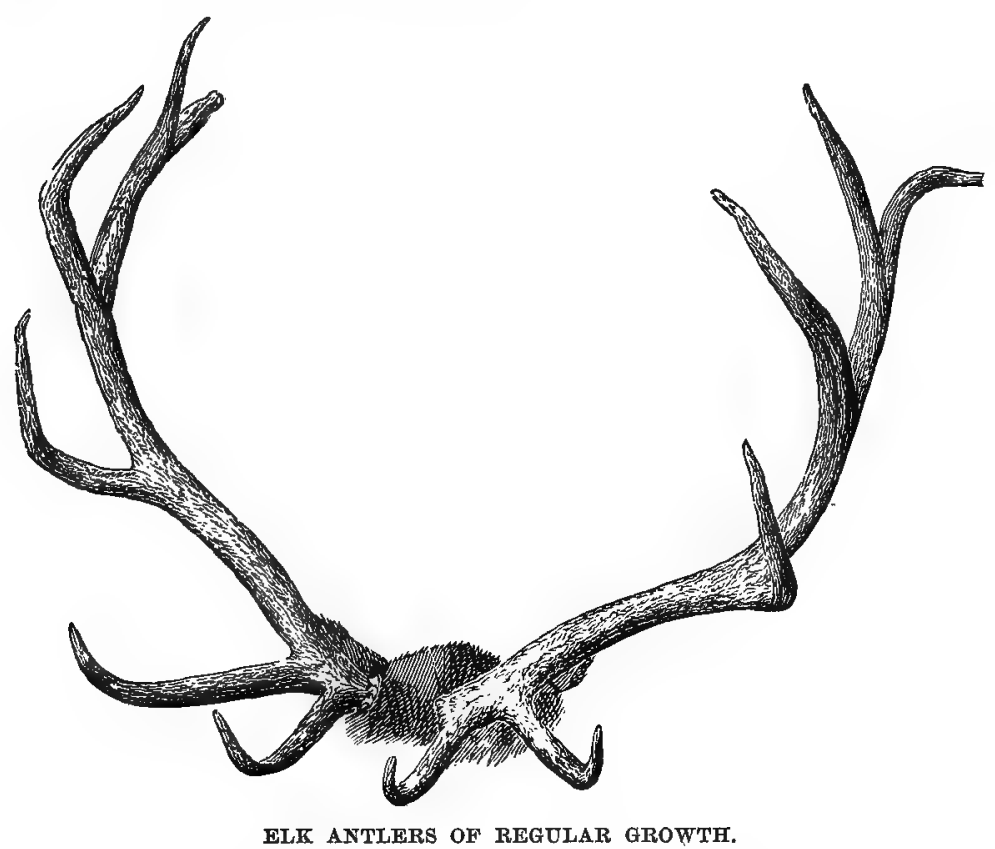

At last the tip of the horn is reached, the capstone laid. Then the gates between the heart and the thousands of little canals are shut down, the velvet, deprived of its support, dies and peels off, accelerated by much rubbing against branches, and the horn, striated and ribbed with the irregular channels of the old blood-vessels, comes out in September strong and bright. "Richard is himself again!"

When one thinks of the breadth and weight of elk antlers - often forty pounds-it is astonishing with what rapidity they are matured. The beam of each horn is sometimes five feet long, and twelve inches in circumference at the base, their tips being three feet apart and reaching almost to the tail whenever the head is thrown back. How great is their bulk, compared with the mass of the body, is represented by the cut on 
page 169, which shows very well the form and rongl coat of the great Wapiti.

Five points constitute a "full" horn, but eight or ten are not overrare, while as many as fifty-one were fonnd on a Californian elk; bat this was evidently a monstrosity. Yet this ponderons pair of horns grows wholly within five months, and the process is repeated each year of the elk's life after the third.

His antler's renewed, and his new coat shining, the proud deer now steps ont of his hermitage and seeks society. He walks haughtily, holding his head high and swaying it from side to side as though calling all the world to witness the admirable spectacle. He is Samson with his hair regrown. Then is heard his shrill whistle ringing through the undertone of "the murmuring pines" and echoing along the rocky cañons. It is his slogan, and every elk within hearing hastens to his standard, except those ambitious of themselves leading highland clans.

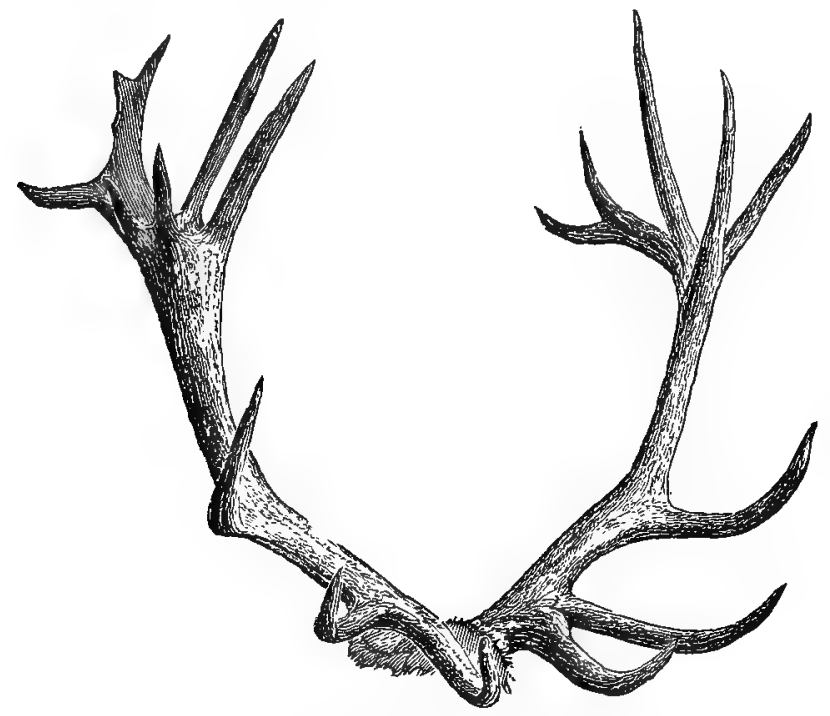

AN IRREGULAR PAIR OF HORNS.

Their systems relieved from strain, young and old grow fat upon the ripe, nutritious grasses, and, as autumn advances into winter, enormons herds band together and seek their winter range in some mountain park where the springs will not completely freeze over, timber affords shelter from the wind, and the snow will be blown off the tops of the knolls where they may go to feed. From October onward, therefore, is the 
time to hunt them, either for flesh or hides or sport. Before the heavy snows come they will be found high up, even above timber line, escaping the flies, whence they descend in the night to the plains by regular trails, easy to follow upon horseback. The elk's favorite gait is a rapid trot, but when he runs it is with a freedom of step more like that of a horse than the bumping jump of the mule-deer or the long leaps of the antelope. The bull elks, stooping their necks and laying their long horns back on their withers, will gallop through thick woods without impediment; but sometimes, when their horns are in the velvet, accidents happen by which they are permanently distorted, occasionally to such an extent as to prevent the animal getting his nose to the ground, and so causing his partial or utter starvation.

Later in the autumn they wander out upon the plains more generally or browse in the gulches, where they are shielded from sight. Very restless animals, they are constantly moving from one feeding-ground to another.

If they have not been hunted, it is not difficnlt to get within riflerange, for after starting to run away they will very likely stop at the first ridge and gaze back.

The surest place to shoot them is behind the shonlder or through the neck; but their hold on life is strong, and remarkable stories are told of the distance they have travelled after being shot through the vitals, and of the amount of fighting they are able to keep up until the last breath has left their lungs.

Nobler game does not exist, and their clarion call is still to be heard through all the northern Rocky Mountains and the neighboring parts of. British America. I saw hundreds on the plains along the Sweetwater River, Wyoming, in 1877, and have heard since of bands containing several hundreds being met with near the Wind River Range. Bnt in Colorado, Utah, and California they have been driven back by civilization until they are wholly absent or very scarce where, twenty years ago, immense herds were to be found.

Indeed, their present range, say from Colorado to Great Slave Lake, and from Nebraska to the Sierra Nevada, is very small compared with the wide area over which they were to be found when Europeans first began to explore this continent; for it is well known that, within the historic period, elks roamed over the whole northern United States, even to the St. Lawrence River, and southward through the Alleghanies to North Carolina, wandering down all the valleys on the Atlantic slope and penetrating the mountainous regions south of the Ohio River. 
Both tradition and written history, in the tales of travel by the earliest settlers and explorers of North America, assert this, and the names of streams and hills confirm it; just as it is positively known that the bison folmerly ranged eastward as far as western New York, and thence southward to the Carolinas, Arkansas, and Texas. This was in addition to all the great fields of the far West to which the elks have been driven by the advance of farming and the growth of towns and railways. I fear it will not be long before they will become almost as rare, even in our wildest north-western mountains and table-lands, as are those noble stags of the Scotch Highlands which our elks so closely resemble.

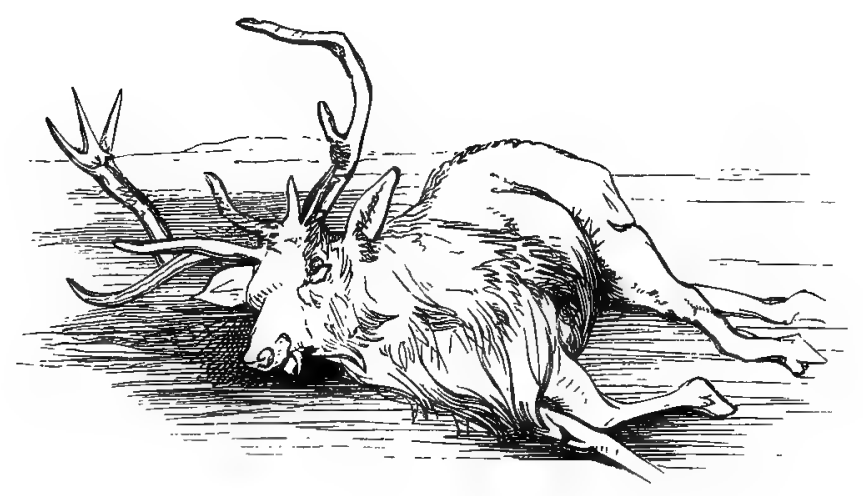




\section{XVII.}

\section{A CHAT ABOUT BOB WHITE.}

THE American partridges (Perdicidoe) have been separated from the 1 Old World partridges into a sub-family (Odontophorinoe), of which we have five genera. Most of these, however, are restricted to the extreme south-west, and there is but one species found thronghout the eastern half of the Union-the common "quail," as it is called in the Northern States; "partridge," as it is dubbed at the South; and "Bob White," as it is recognized everywhere-whose scientific name is Ortyx virginianus.

The trisyllabic call of the quail is suggestive of a song; its strong, short flight recommends it to the gunner; its delicate flesh is toothsome to epicures; its habits and history are full of interest to everybodyeven to the poets, for whom the lark, the robin, and half a dozen other singing-birds usually suffice.

The quails remain in the upland grain-fields and open woods the year round, even on the upper Missouri where the mercury falls to $30^{\circ}$ below zero, wandering about in bevies, and feeding upon anything palatable. It would perhaps be more accurate to say that some quails are to be found in such situations the year round, since it is probable that in the northern portions of their range they move southward, for the most part. In the South, however, their migrations-if they may properly be termed so-are local and irregular, and not general, as are the great flights of the migrating quail of eastern Europe. Ours are restless, uneasy birds, attached to one place while rearing their family, but immediately upon the brood becoming able to travel commencing their wanderings. There is no accounting for these movements, which sometimes deprive a whole district of their presence for a time, to populate an adjacent region previously without them. One of the few examples of any regularity of movement on record is the assertion that every fall quails cross the Mississippi, from the Kentucky to the Missonri shore, in large numbers, stopping to rest at Island No. 10. It has also been stated that, when such journeys 
are undertaken, a very large number of birds participate, travelling on foot, and passing steadily through districts where food is abundant, as though they had a definite destination in their minds. This has been observed even along the Chesapeake Bay. They are so loath to use their wings, that large numbers are said to perish in attempting to cross wide rivers and inlets. Such impulsive marches remind one of the erratic migrations of squirrels and some other animals, which take place in an unlooked for time and manner; nevertheless, it must be admitted, I think, that a partial and limited migration takes place annually from the more northern to warmer latitudes, which is influenced in its extent by the comparative severity of the seasons; and, furthermore, that the quail is more distinctly migratory west than east of the Delaware River.

About the middle of March the winter flocks break up, and the mating begins; but if the weather is late in becoming settled, the wooing is deferred. Although not indulging in the noisy antics with which the gronse calls attention to its personal attractiveness, Bob White becomes suddenly conscions of his comely appearance and good voice. Having no false pride, he invites the opposite sex to look at him as an eligible partner, and proudly walks abont, head erect, that they may view him at his best. He seems to understand that the law holds its oegis over him now, and from the orchard gate calls a saucy good-morning to the farmer starting to market. He knows that he is attending adequately to his department in the great business of nature, and is by no means fearless of being seen. But he keeps an eye to hawks, cats, and other predatory enemies that respect neither time, place, nor season. He is polygamous, willing to take any amount of family responsibility, and will help to rear two, or occasionally even three broods every year. A snccessful pair of quails often turn out twenty-five young in a season, and it is not uncommon to find a covey of these little "cheepers," hardly able to fly, even as late as November.

Althongh paired so early, the quails do not at once proceed to the business of nidification, and will often be flushed in company when you are snipe-shooting in April. About the middle of May (in the central parts of their range) is the time when the nest is built. The situation chosen is the leeward side of some dense tussock of grass, or mouldering stump in a wild, matted meadow, at the bnshy margin of a clover-field or orchard, or in an old pasture overgrown with bramble thickets; and the female, as is her undoubted right, takes the lead in fixing upon the site. The more civilized the locality, the denser the cover sought. The nest is an inartificial bed of grasses and vegetable trash, filling a shallow depres- 
sion. Sometimes it is so placed as to be concealed by naturally overarching grasses, through which a regular tunnel. (sometimes several feet long) conducts to the sanctum; and at other's it seems to be covered with leaves and straws, rudely arranged by the birds. The nest is constructed solely by the females of the family, and varies in dimensions according to the number of quailesses-if I may use the expression-that anticipate using it; the inale bird meanwhile going abroad in quest of food, or sitting on a low twig close by, constantly cheering his wives by his chapacteristic note, and very faithfully warning them of the approach of danger.

The work is prosecuted with zeal, and three days at farthest suffice to make the nest ready for an egg, the first of which is immediately laid, and is followed, one each consecutive day, till seven or eight have been deposited, as a rule; it is on record, however, that as many as thirty eggs are sometimes found in one nest. This is due to the polygamy of the male, which was noticed by the earliest sportsmen and ornithologists. Mr. Thomas Gentry tells us that in Pennsylvania commonly two, and often three and four females, are taken by one male, and that two will lay in the same nest simultaneonsly - besides which different families occasionally lay eggs in each other's nests. "When a pair has established itself in a locality from the first," he says, "and has been successful in rearing a family of young during the ensuing spring, if the females are in the majority the unprovided ones still continue, as a general thing, to linger with the parents after their more specially favored companions have mated and moved elsewhere. This is particularly noticeable in a new locality, where the covey consists entirely of members of a single family. In cases where several families congregate in the fall, the chances are greatly in favor of monogamy. Small flocks are more decidedly polygamous than larger ones. We have never observed the converse-that is, more than one male to a fernale-but where several pairs are found in the same tield, at slight distances from each other, there is sometimes a noticeable tendency to associate."

The eggrs of the quail are crystal-white, occasionally faintly tinged with yellow, and pyriform in shape. The eggs are sat upon about eighteen days. Where the father is not fortunate enough to possess a harem a large part of the work falls upon him, while the mother seeks rest and food; but where there are several females the male takes no part in the labor of incubation, which the females divide very amicably among themselses, each sitting about half a day at a stretch, then calling her relief with a low note, if there be only two; while, if the family be larger, two 
fernales will sit side by side on the eggs-too many in number to be kept warm by a single breast.

Meanwhile the husband remains close by, chirping in a low tone, and at frequent intervals making the field ring with his sonorous whistle. $\mathrm{He}$ is exceedingly watchful, and if a human being approaches the nest -after giving the alarm to his partners, who secretly withdraw from the nest-he flings himself upon the ground in front of the intruder, simulating lameness or injury, and secking by every art to attract attention and pursuit, until he has beguiled the enemy far away from his home, when he seeks his own safety in swift flight. The experienced oölogist pays no attention to this deceit, but seeing in it only a sure sign that he is near the coveted nest, pursues his search diligently until he succeeds in discovering its whereabouts.

A second brood is almost invariably reared, and often even a third, the latter not appearing until late in the summer, and hardly getting their growth before snow comes. The species, therefore, if nnmolested, would increase with great rapidity, as has been shown by the celerity with which they have replenished an area from which they had been all but exterminated, when a period of quiet for a season or two had been allowed them. As soon as they leave the shell the young run about in a very lively way, and are in a few days given over to the care of the father, whom they follow about and obey as readily as they did their mother, perhaps because they do not recognize the change of guardians, while she returns to the cares of rearing a second family.

If ruthless death deprives the little flock of two or three members, the rest, scattered before the gun, will continue calling to one another far into the shades of night.

During the spring and early summer the quail finds an abundance of food for itself and its young in the larvæ of various insects just emerging from the earth, the succulent shoots of growing plants, and such seeds as they can find; later they are supplied with strawberries, blueberries, huckleberries, and various other wild fruits; and in August feed upon grasshoppers, when they become fat. Then the seeds ripen, acorns and beech-nuts fall, many late berries still hang upon the stems, the stubblefields are full of scattered wheat, rye, barley, and maize, insects are plenty upon the ground, and so the quail is feasted before the winter begins, until he becomes of that delectable plumpness esteemed by bon vivants.

Attaining their full growth and final adult plumage by the end of September (at least in the case of the earlier broods), the season of play for the partridges and sport for the gunner has come. 
In the United States quail-shooting is regarded as a test of marksmanship, and in the Eastern and Middle States, where the birds are hunted so incessantly that they have become rare and wild, it certainly requires skill and good slıooting to make a bag. Frank Forester gave it as his opinion that no bird in this country or any other country was so difficult both to find and to kill with certainty. Bred in the open fields, and feeding early in the morning and late in the evening-between which times they hide quietly, huddled together in little knots which the best of dogs might easily pass without discoveling-a man may beat a field all day, and put up only one or two birds, when he is certain that thrice as many are concealed there. Often, too, if the sportsinan passes close to them, they will sit inmovable, trusting in their inconspicuous colors to conceal them until he has gone some distance beyond, when they will spring up and away like so many arrows. It then requires a quick eye and a steady hand to turn and drop a brace.

When ultimately flushed, they are very fond of flying to some particular covert; and so long as this thicket or fern-brake remains nndiscovered, they will resort to it repeatedly. Their concealnent is aided by another curious circumstance, which has occasioned much discussion among American sportsinen.

It is asserted that, when alighting after being flushed, the quail gives ont no scent for some little time; and it has been supposed that this retention of odor is voluntary on the part of the bird, as a conscious method of protection. This is believed in by many persons. Forester admits the fact, but considers that it is only exercised under peculiar circumstances, and commits himself to no explanation. Some shooters believe it is a power belonging to particular bevies, at least in a far greater degree than to others, like the custom of alighting on the branches of trees when frightened; other's restrict the faculty to particular individuals rather than bevies; while the earlier ornithologists do not mention the "retention of scent," and the later claim (which is probably true) that quails' swift running over the dry leaves of upland woods or meadows allows little time and a poor surface for the transmission of scent, and that when they drop suddenly and remain quiet no efflnvium escapes, although the instant they move it begins to be disseminated. It would be better, therefore, having marked down a bevy of quails, since the gunner may be sure they will stay for some time exactly where they have dropped, to wait a few moments before sending the dog on.

But, having found your quail-which, after all, is not difficult for an experienced sportsman with good dogs-there yet remains the skilful art 
of killing him. Quails jump up with a loud whir, which may easily startle the sportsman and spoil his aim; hence he mnst make himself proof against any such tremor of surprise before he can hope to have success.

As the wild winds of November smite the open fields and break the bruised reeds the quail retreats to the depths of the swamp or the shelter of a dense thicket, and keeps life in him the best way he can during the cold and stormy days-hunting the swamp and stubble for soft-shelled nuts and seeds, torpid beetles, the hard fruits and seed-cases of various grasses and weeds, some of which, like the skunk cabbage, taint his flesh with their flavor. The forlorn covey huddle together and allow the snow to cover them, trusting to shake it off in the morning; but sometimes a crust freezes upon the surface, and the poor birds find themselves in a prison from which they cannot break out before they starve to death. Great numbers miserably perished in this way in New Jersey in the winter of $1835-36$, and again in Massachusetts in the winter of 1866-67.

This habit of huddling together is one very characteristic of quails all the year round. At evening they select some spot of low ground, where the long grass affords shelter and warmtl, and encamp, sleeping in a eircle, shonlder to shoulder, with their heads out, keeping each other warm, and all ready to escape at an instant's notice without tumbling over one another. A good roosting place once found, they go back to it night after night, leaving it in the morning just before sunrise to seek theil breakfast.

Unless the winter be unusually mild, the farmer will frequently find quails associating with his cattle in the pasture, and even following them home to glean the grain that falls abont the barn-yard, and pick up the scraps thrown to the chickens. I am happy to say that this delightful confidence is not often abused, and many persons take pains to foster bevies which they find spending the winter in some copse or brushy hillside near the house, by daily sprinkling grain or clover-seed upon the snow where the hungry birds may come and get it. It is reward enongh -if the benefactor cares not to preserve them for the selfish pleasure of shooting them the following autumn-to see the pert air with which one of the cocks will perch himself on a fence rider, or walk sedately along a stone wall in the early sunlight of a glistening January morning.

As a delicate article of food the quail is greatly prized, and during the time allowed by law our markets are filled with bunches of them. Various devices in the shape of snares, nets, and traps have been and 
are now called into service to effect its capture, until, in New England, where it was once very abundant, and was not early enongh protected, it is fast disappearing, and fresh importations have been found necessary to preserve a sufficient number for sport. In the Southern and Western States bands of beater's cautiously drive immense flocks into nets. But there is less danger of exterminating this than perhaps almost any other species of game-bird, on account of its sequestered habits and prolificacy.

Taming and domestication is an easy matter, although in all cases where the eggs have been hatched under a hen at liberty-a bantam is the best-the quail chicks have run away to the woods as soon as the leaves began to turn sear in the fall, and nerer come back. They sang out their "Ah, Bob White" just as clearly before they had ever heard one of their kin as any woodland-bred quails could do. It is not uncoinmon to re-colonize portions of the Eastern States that lave become depopulated, and an effort made to introduce the bird into the Salt Lake Valley of Utah sncceeded admirably. Some of the West India islands have been colonized in the past few years, and I see no reason why this quail might not, with care, be acclimatized in Great Britain, and thrive in English preserves until there are plenty for all the purposes of good sport; yet up to the present time the attempts which have been made in England and Ireland to do this have completely failed. 


\section{XVIII.}

SEALS AND SEAL-HUNTING IN THE NORTH ATLANTIC.

HALF a dozen years ago I knew a blue-eyed, brown-haired, and peach-cheeked little girl, whom her father used to call his "harborseal." If you had ever seen her lying face down in the cradle-her favorite position - holding up a round, fuzzy little head, you wonld have understood at once why he called her so; for that is precisely the way a seal looks when it is resting on a rock or a piece of ice.

Scores of years back, before the settlement of North America by Europeans, seals were wont to come to its shores eren as far southward as the Carolinas, and were common visitors from New Jersey northward. Robin's Reef, in New York Bay, passed by all the Coney Island steamboats, gets its name from the Dutch word robin or robyn_"seal "-because those animals used to resort there in great numbers. To-day they are uncommon even along the coast of Maine, scarcely abundant in the Gulf of St. Lawrence, and are slowly being driven inside the aretic circle.

Now this disappearance of the seals from our own coast has been brought about by incessant persecution, and it seems to me very unfortunate. How much it would add to the pleasure of a voyage down the bay, or a ramble along the weedy and wave-polished beach, if we conld see, here and there, trim, brown animals creep up from the water on some projecting rock, shaking the drops of water from their coats, and gazing at $11 \mathrm{~s}$ with no fear in their mild eyes! But sadly for our amusement, and for the seals themselves, their bodies have a value in the market - and great fleets every year are fitted out to engage in this fishery.

The word "fishery" ought to imply a "fish" to be cangltt; but the term has become perverted: for instance, we speak of whale, sponge, coral, crab, and oyster, or clam fisheries, yet none of these animals is in the least a fish. Neither is the seal, although it lives in the water, swims and dives. It is, indeed, nothing bint a warm-blooded, fn1-coated mammal, with all the internal organs and outside structure of a quadruped. 


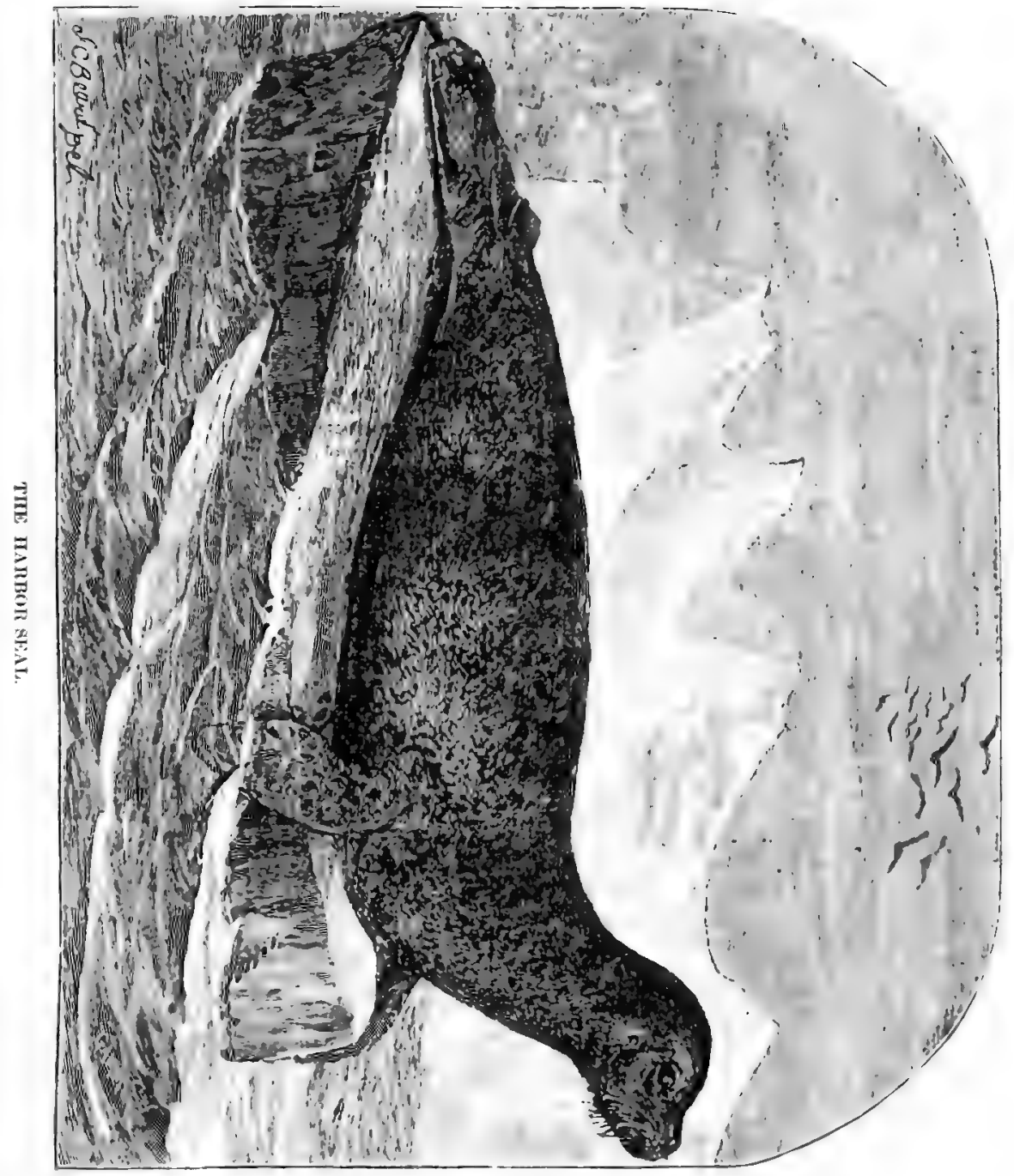



"What!" you exclaim, "all the outside structure' of an otter, for example?"

Yes, but not the same appearance. Let me explain to you how this is. If we could study the outlines of the heads of both, and compare the skulls, or pictures of the skulls, of the seal and the otter, we should see at once how the bones, and the shape and arrangement of the teeth in one resemble those in the other. And if we had also a picture of the skull of a codfish, we should see how different from it are the skulls of the otter and seal.

Now look at the limbs. I have heard of a boy who defined a quadruped as an animal having a leg at each corner. Perhaps that would fit the otter, but you think that, certainly, it would not describe the seal, "which hasn't legs at all," you say, "but fins or "flippers."

If I had the time, I could prove to you that the difference between the fin of a fish and the bone-leg of an otter or of a dog, or your own arm, is not so vely great; and it would be easy to show low nearly alike the flipper of the seal and fore-leg of a land mammal really are. On examining diagrams of the bones in a seal's flipper and an otter's fore-leg, you will find that you can match every bone of the one by a similar bone of the other. The shapes of the bones, to be sure, are altered to suit the varied uses of swimming in the water and walking on the land; but all the parts of the arm and hand (or fore-foot) of the otter, or any other mammal, are seen also in the flipper of our subject-only there they are shortened, thickened, and covered with a membrane which converts them into a paddle instead of a paw.

The same comparison will hold good for the hind-feet of the otter and the hind-flippers or "tail" (which is not a tail) of the seal; and it is equally true of the walrus, and of the whale, porpoise, grampus, blackfish and other cetaceans.

Of conrse, being mammals, these animals must breathe air. You could drown any of them by forcing it to remain under the water too long. Whales can stay down an hour or more, if necessary, and seals can hold their breath for fifteen or twenty minutes, though thcy do not like to be under as long as that. Of course, therefore, it is necessary for seals to be able to reach the air, even in spite of the sheet of thick ice which for half the year covers the whole ocean in the arctic seas, where mainly is their home. But in large bodies of ice there always are some holes, no matter how cold the weather may be; and these holes afford the seals of that region an opportunity to come to the surface to breathe. There are some species, however, that keep round, smooth-edged air-holes open for 
themselves by continually breaking away the young ice as fast as it is formed. These holes are never very large at the surface-sometimes only big enongh to let one animal poke his nose up throngh; they are much like chimneys, indeed, for the ice may sometimes be a hundred feet thick.

Before I go further, let me say that the word "seal" applies to several families of pinnipeds, only one of which concerns us at present. This is the Phocidce, or family of earless seals, of which the common harbor-seal, the ringed seal, the harp or Greenland seal, and the bearded or hooded seal, are chiefly to be remembered. Concerning the gigantic sea-elephant of the antarctic pole, the huge sea-lions of the Pacific, and the varions "fur" seals, we have no occasion to speak. All our present subjects inhabit the coasts of the arctic zone washed by the North Atlantic, and principally Greenland and Newfonndland.

While the breathing-holes in the ice afford the seals their only possibilities of life, they often prove to be death-traps, since many foes lie in wait near them.

The enemies of seals, other than man, are not a few, both on land and in the water. The polar bear, finding their holes, watches as quietly and vigilantly as a cat for a monse, and leaps upon them as they rise to breathe, or eren chases them into the sea, and so captures a great many. The arctic wolves and foxes, the raven, and probably also the great snowy. owl, attack the young before they are able to defend themselves or escape, making their onslanghts so actively that the heavy and awkward parents have hard work to defend their babies. The full-grown seals, as well as the young, are seized in the water by sharks and sword-fish, and also by killer-whales, which, though of small size, are able to conquer the monstrous right-whale.

Travellers say that when a sword-fish sees a seal upon a floating "pan" ol cake of ice, he will get on one side and tip the pan down to such an angle that the seal must slip off, and then will devour it. So great is a seal's terror of these water foes that, should a man be on the pan when sword-fish and sharks are after him, the seal will run between his feet for protection. Many sẹls are killed, too, by fighting among themselves, and by the fierce storms of the frozen zone.

The most ingenious and dreaded enemies of the seal, however (leaving out of sight for the present the white men), are the Eskimos. To them seals are of the utmost importance, and we may say that in many parts of the aretic world men could not live without these animals. The Eskimos' methods of hunting this game, and the hundred ways in which they utilize its body, will be interesting matters to look into. 
The harbor-scal is, perhaps, the least serviceable of seals, since he is not common very far north of Labrador; but his flesh is considered the best, and on the Pacific coast the Indians take whole herds at once, by stealing "upon them when they are basking un the beach or in shallow

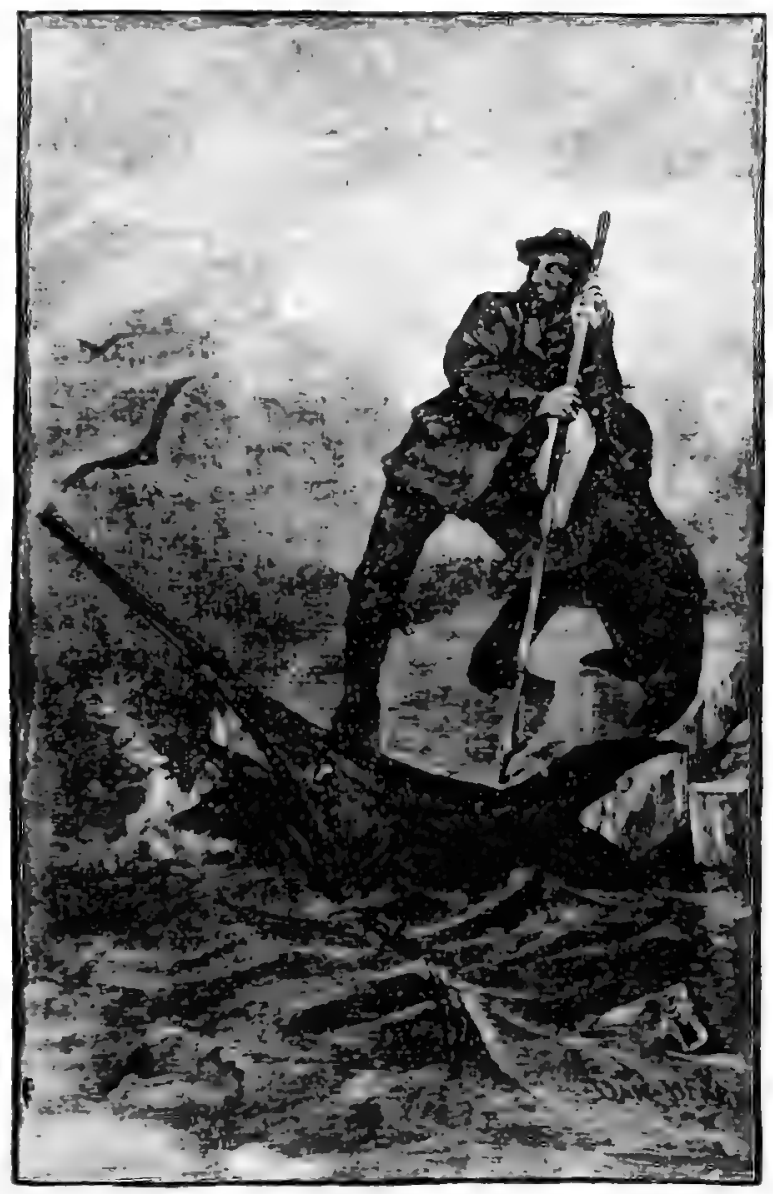

PANIC-STRICKEN BY A sWORD-FISI.

brys, and drawing a seine around them. The hides of the old ones are good only for tents, but those of the young are highly prized; and no present is more areceptalile to a (ireenland damsel than the prettily mottled skin of a kussigniml (as she would eall it), out of which she will make the wide, warm trousers that serve her in the place of petticoat.

Another seal, of which the Greenlanders do not get many-the hooded 
seal-is very large, and is especially prized on account of the thickness of its skin. Ont of it they make not only. the slender-pointed canoe-like boats, called "kayaks," in which they chase this and other wandering species, but also the stont lines to which their harpoons are attached. It gives durable soles for their boots, too, and strong harnesses for the dogs, besides which the flesh is sweet. It is one of the most easily killed of all seals, becanse it is not watchful. The harp-seal is also readily killed along the edges of the ice-floes* by the kayalker, but he values it little, excepting to eat; the bearded seal, or "square-flipper," on the contrary, shows fight, taxing the courage and skill of the bravest of those hardy natives to overcome its fierce resistance and avoid its terrible bite.

The one seal useful above all others to the Eskimos, and eagerly pulsued, is their favorite netsick, one of the smaller species, frequently called in our books the ringed seal, or "floe-rat." It is confined to the polar seas, rarely wandering sonth of Labrador, but it belongs also to the aretic shores of Europe, Asia, and Alaska, so that not only the Eskimos proper, but many arctic Indian tribes, regularly hunt it.

Although it is hunted throughout the year, the most profitable time for killing the netsick is in April, when each nother seal is accompanied by a young one. Here, perhaps, I may digress a little in order to tell you something of the babyhood of the Greenland or harp seal.

Of the different sorts of seals I have mentioned, all but two are migratory - that is to say, the whole body of them move from north to sonth each autumn, and back from south to north each spring. Upon this inportant fact the great fleets of fishermen, of which I shall give an account presently, depend for their success. The annual southward journey of the restless harp-seal furnishes a vivid picture of these great migrations which are so prominent a featnre of polar history. Keeping just ahead of the "making" of the ice, or final freezing up of the fiords and bays, at the approach of winter they leave Greenland, and begin their passage sonthward along the coast of Labrador, freely entering all the gulfs and bays. They appear first in small detachments of half a dozen to a score or more of individuals; these are soon followed by larger companies, until in a few days they form one continuous procession, tilling the sea as far as the eye can reach. Floating with the arctic current, their progress is extremely rapid, and in but one short week the whole multitude has passed. Arriving at the Straits of Belle Isle, some enter the gulf, but the

* A field of floating ice, in the arctic phrase, is a "floe," so long as it remains a firm sheet; when it breaks up it becomes a "pack," or "pack-ice." 


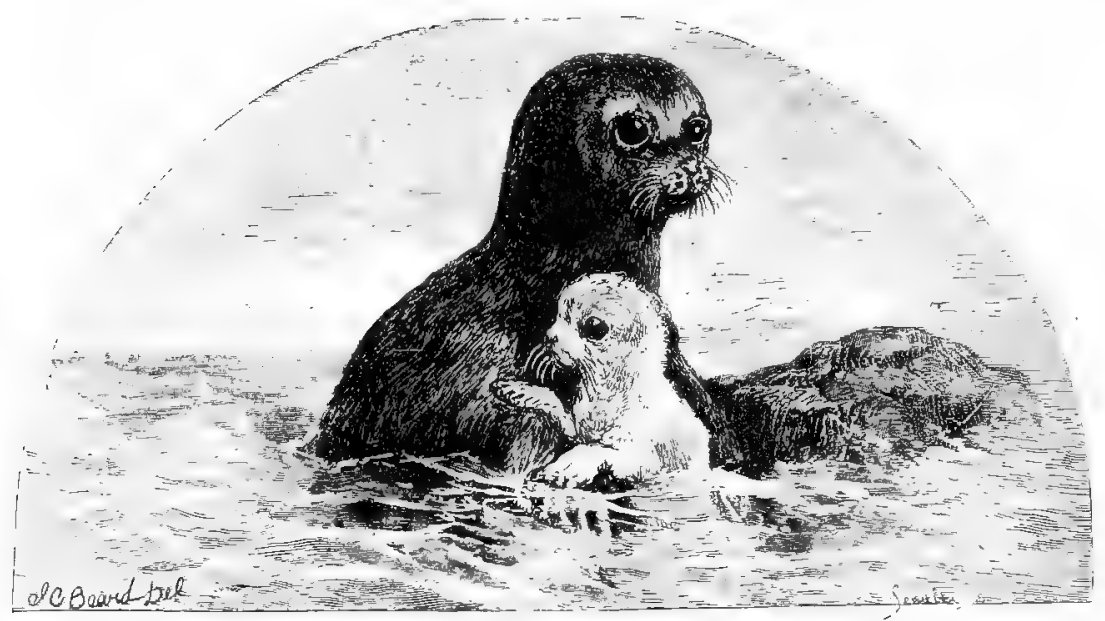

A HARP-SEAL MOTHER AND HER LITTLE ONE.

great body move onward along the eastern coast of Newfoundland, and thence outward to the Grand Banks, where they arrive about Christmas. Here they rest for a month, and then they turn northward, slowly struggling against the strong current that aided them so much in their southward journey, until they reach the great ice-fields stretching from the Labrador shore far eastward-a broad continent of ice.

During the first half of March, on these great floating fields of ice, are born thousands of seal-babies-only one in each family, to be sure, but with plenty of play-fellows close by-all in soft woolly dress, white, or white with a beantiful golden lustre. The Newfoundlanders call them "white-coats." In a few weeks, however, they lose this soft covering, and a gray, coarse fur takes its place. In this uniform they bear the name of "ragged-jackets;" and it is not until two or three year's later that the full colors of the adult are gained, with the black crescentic or harplike marks on the back which give them the name of "harps."

The squealing and barking at one of these immense nurseries can he heard for a very long distance. When the babies are very young, the motlıers leave thern on the ice and go off in search of food, coming back frequently to look after the little ones; and although there are thousands of the small, white, squealing creatures, which to yon and me would seem to be precisely alike, and all are moving abont more or less, the mother never makes a mistake nor feeds any bleating baby until she has found her own. If ice happens to pack around them, so that they canuot open loles or get into the water, the whole army will laborionsly travel by floundering 
leaps to the edge of the field; and they show an astonishing sagacity in discerning the proper direction. It is supposed that they can smell the water at a long distance.

Sometimes great storms come, breaking the ice-floes in pieces and jamming the fragments against one another, or upon rocky headlands, with tremendous force. Besides the full-grown seals that perish in such gales, thousands of the weak infants are crushed to death or drowned, notwithstanding the dauntless conrage of their mothers in trying to get their young ont of danger and upon the firm ice. And it is tonching to watch a mother seal struggling to get her baby to a safe place, "either by trying to swim with it between her fore-flippers, or by driving it before her and tossing it forward with her nose." The destruction cansed by such gales is far less when they happen after the youngsters have learned to swim.

Does it surprise you that seals which are constantly in the water have to learn to swim? Well, it might stagger tlie phocidæ to be told that men have to be taught to walk. The fact is, a baby seal is afraid of the water; and if some accident or his mother's shoulder pushes him into tlie' surf when he is ten ol a dozen days old, he screams with fright and scrambles out as fast as he can. The next day he tries it again, but finds himself very awkward and soon tired; the third day he does better, and before long he can dive and leap, turn somersaults (if he is a bearded seal), and vanish under the ice, literally "like a blue streak," the instant dangel" threatens. But he had to learn how, to begin with, like any other mammal.

It is when the seals are busy in caring for their helpless babies, and giving the better grown youngsters their early lessons, that the Eskimo hunters seek most diligently to kill them. This is not merely for the pleasure of it-not that at all, perhaps-but because their flesh and skins are imperatively needed. Those chiefly pursued by Eskimos, however, are not the species that make the great migrations I lave just described, but ringed seals ( $P$ hoca foetida), whose habit it is to remain on the high aretic coasts all the year round. Upon this animal the Eskimos place alunost their entire dependence for food, fuel, light, and clothing. Its capture is therefore exceedingly important to every family.

At the end of winter each of the female seals of this species creeps up through the breathing-hole (athk); and under the deep snow overlying all the ice-field she digs a cave, eight or ten feet long and three to five feet wide. At one end of the excavation is the breathing-hole, affording a ready means of letreat in case of danger. In this cave the young seal is born, and though protected from the sight of its enemies, here it is often captured. 
About the first of April the Eskimo hunter leaves his winter encampment, taking his family and a few bits of furniture on his dog-sledge, and goes to some locality where he expects to find seals abound. Arrived there he cuts ont square blocks of hard snow, piles them up into a round lut with a domed roof, clearing away the snow from the inside down to the hard ground or ice-surface. Over this hut he throws water, which, in freezing, cements all the bloclss together; and then he has a good tight house, as warm as though made of stone. This done, he and his family

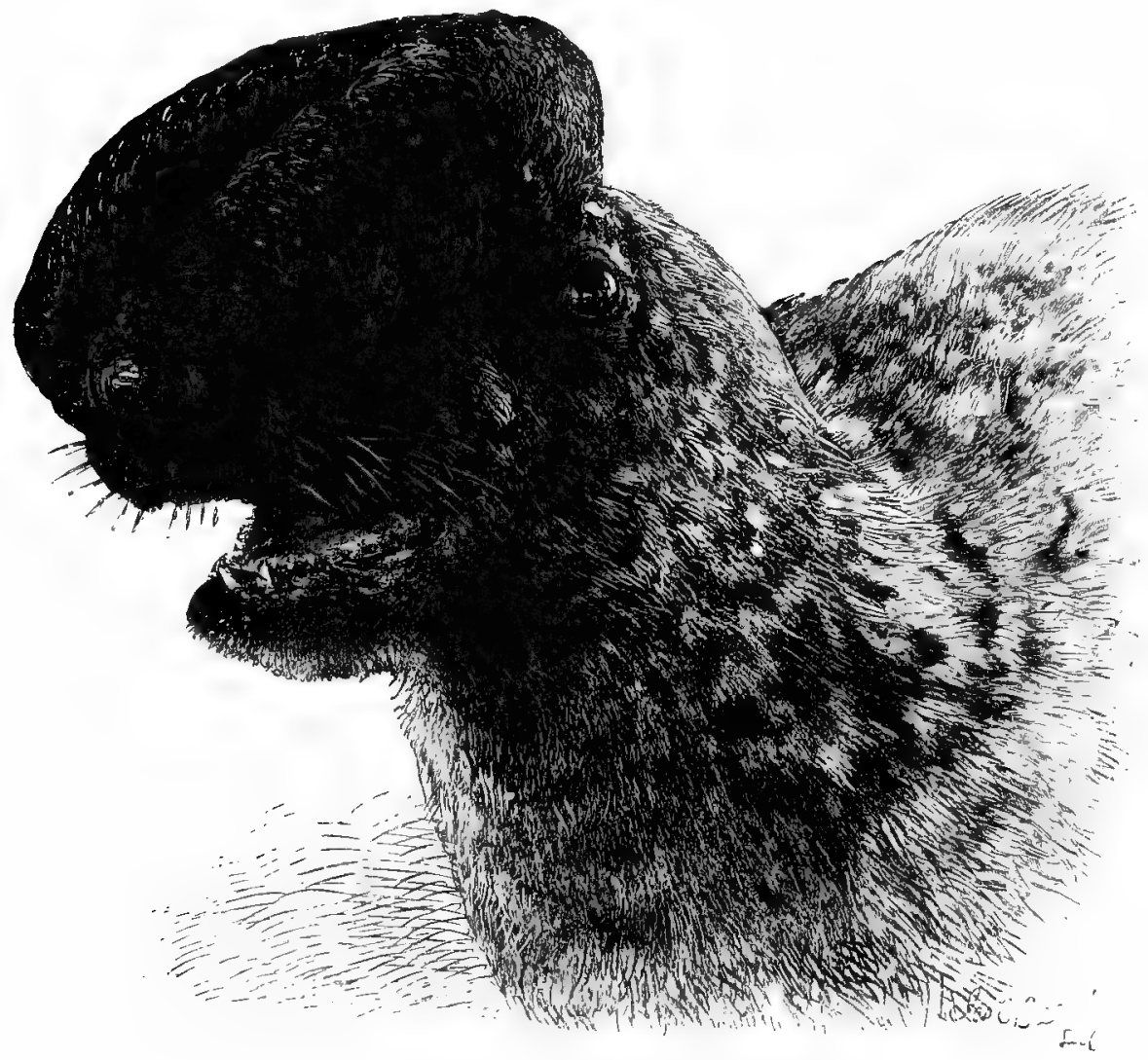

TIE IIOODED SEAL-CYSTOPIORA CRISTATA.

are as comfortable as if they were at their winter home; and if his hunting is successful, he is contented and liappy.

The old-fashioned native manner of hunting-some of the Eskimos now have guns, and this spoils the interest-called for much skill and 
patience. In it each hunter has a trained dog which runs on ahead; but is held by a strap around his neck from going too fast and far. The dog: scents the seal, lying in its excavation under the snow (the level surface of which, of course, gives no sign of the cave), and barks; whereupon the hunter, who is close behind, hastens forward, and by a vigorons jump breaks down the cover before the young seal can escape. If he succeeds in cutting off its retreat it is an easy prey, for he simply knocks it on the head; otherwise he must use his seal-hook very quickly or his game is gone.

"It sometimes happens," says Mr. L. Kumlien, "that the liunter is unfortunate enough to jump the snow down directly over the hole, when he gets a pretty thorongh wetting. The women often take part in this kind of sealing, and become quite expert. The children begin when they are four or five years old: the teeth and flippers of the first catch are saved as a trophy, and are worn about the little fellow's neck; this they think will give him good-luck when he begins the next year.

"As the season advances, and the young begin to shed their coats, the roof of their igloo or cave is often, or perhaps always, broken down, and the mother and young can be seen on sunny days basking in the warm sunshine beside their atluk. The mother will take to the water when the hunter has approached within gunshot, and will leave the young one to shift for itself, which generally ends in its staring leisurely at the hunter until suddenly it finds a hook in its side. A stout seal-skin line is then made fast to its hind-flipper and it is let into the atluk. It of course makes desperate efforts to free itself, and is very apt to attract the attention of the mother if she is anywhere in the vicinity. The Eskimo carefully watches the movements of the young one, and as soon as the mother is observed, begins to hanl in on the line; the old one follows nearer and nearer to the surface, until at last she crosses the hole at the proper depth, when the deadly harpoon is planted in her body and she is quickly drawn out. If, however, the mother has seen the hunter approaching the atluk, she will not show herself."

Norwegian sailor's declare that the seals as they lie sleeping on the ice are carefully guarded and watched over by gulls (Larus glaucus), or "burgomasters," as they are more frequently called; and that these birds act the part of faithful sentinels, warning them on the approach of danger. Captain Albert Markham, when cruising off Nova Zembla, in 1879, was once in a position to corroborate this assertion, and has recorded the facts in his history of the voyage of the Isbjorn. His companion, Sir H. G. Booth, had left the ship in one of the walrus boats to 
shoot a seal which had been observed asleep on the ice. When he had approached to within abont a hundred yards of his would-be prey, Captain Markham saw a comple of these burgomasters soaring over the animal, nceasionally swooping down close to its head, as if imparting some confilential communication. The Norwegian sailors on board at once drew

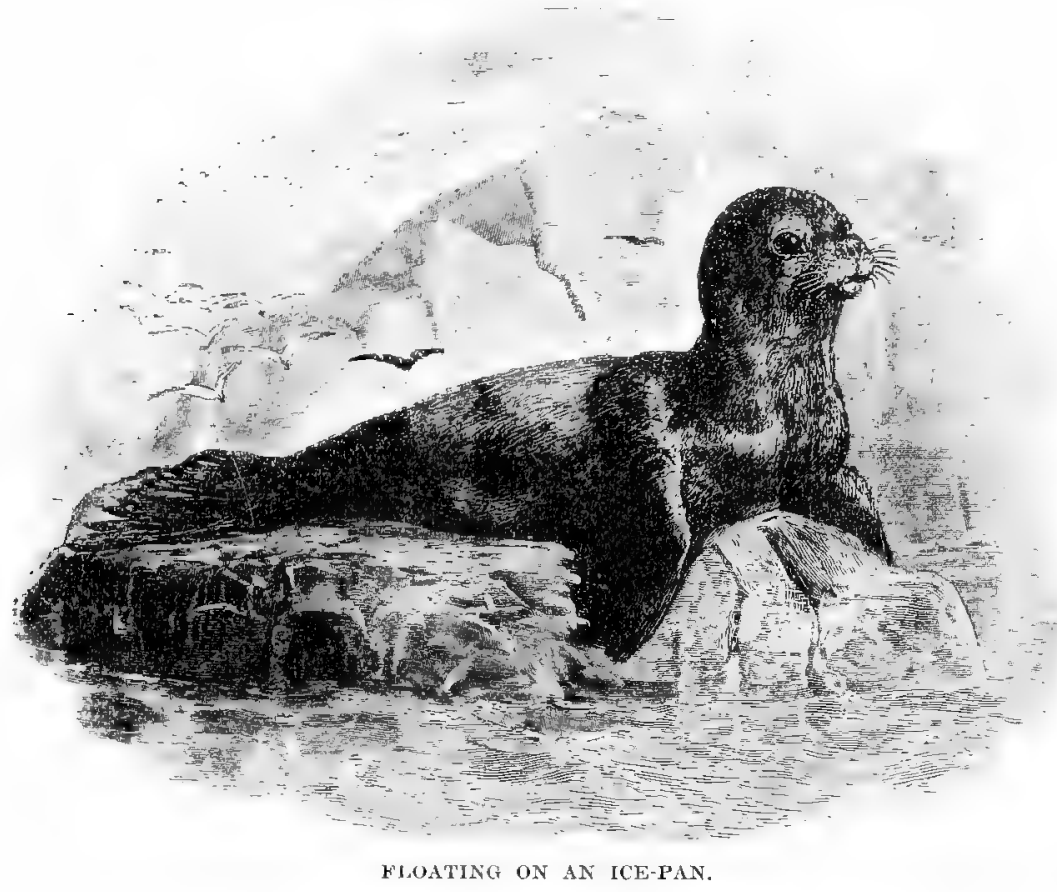

attention to the circumstance, at the same time saying that the birds were warning the seal of danger! The latter, howerer, took no notice, except to lift its head and look for a moment in every direction but the right one. As the boat approached nearer the birds alighted on the ice, and walking up to the seal deliberately pecked it, as much as to say, "It's quite time to be off," on which the seal again raised his head, sighted the danger, and suddenly diving into his blow-hole, disappeared, sadly to the discomfiture of the sportsman. Captain Markham relates the fact as it occurred, thongh it was the only instance of the kind that came under his notice; yet it is not difficult to believe when one remembers the behavior of the rhinoceros-bird of Africa, and other small "sentinels," whose alertness is a means of safety to larger and less wary animals.

If you were to examine the weapons by which the Eslimos manage 
to capture these and other seals-specimens of them are in the National Musem at Washington-you would be astonished at their roughness. It is very difficult, especially for the northern bands, to get any wood excepting sticks that are washed ashore, and a piece long enough to make a good spear-handle is extremely rare. In most cases, therefore, they are obliged to splice two or three short pieces together, and this they can only do by slanting both ends, and binding the pieces at their juncture with strings of raw-hide or strips of intestine. The striking end of the spear. nsually consists of a long and pretty straight piece of bone, such as can be got from a whale's or walrus's skeleton, and this is tipped with a sharp point of bone or flint, or (nowadays generally) of iron. Sometimes this tip is movable, so that when it penetrates the flesh it will slip off the staff and be held only by the line, while the handle floats, secured to the line by a loop.

Other spears have a skin buroy attached, this making it more difficult for the poor animal to swim away, and also helping to float the weapon if the hunter misses his aim. The stout lines are made of seal-hide, or sometimes of braided spruce-roots. The "hooks" mentioned above have wooden or bone shafts, to the end of which a curved and sharpened hook of bone is firmly bound. Besides these, other rough weapons, and a kind of net, are used in the capture of these wary animals, in all of which the seal's hide and bones contribute to his tribe's destruction, and which are marvels of savage ingenuity.

Many of them are used later when the ice breaks up and the Eskimos can go out on the ugliest of voyages in their kayalks, the crankiest of primitive craft; but this is an adventure they never shirk, and one that their acquaintance with Europeans has not changed at all. The 'kayak is eighteen or twenty feet long, but is so light that it can be carried by the one man who forms the crew. It is all decked over, excepting a little ronnd hole through which the young Eskimo squeezes his legs and sits down. Then he puts on a tight oil-skin coat over his garments, and ties it down to the deck all around him, so that no water can pour in "tween decks." But, on the other hand, he must untie the knots before he can get ont; so, if by chance he capsizes, he must either be content to navigate head down and keel up, or else must right himself by a sort of somersault, which shall bring him up on the opposite side-and this he often actually does.

When the kayaker catches sight of a seal he advances within about twenty-five feet of it, and hurls his harpoon "by means of a piece of wood adapted to support the harpoon while he takes aim," called a throw- 
ing-sticl. Curionsly enough, the fal-distant Australasians had a similar contrivance for hulling javelins. As he throws, the kayaker loosens the bladder and tosses it off. The animal struck dives, carrying away the coiled-up line with great speed; if in this moment the line happens to become entangled, the canoe is almost certain to be capsized and dragged away, with no chance of rising again, and many an Eskimo has lost his life through such a. mischance. But if the attack has been successful, the bladder moving on the surface of the water indicates the track of the frantic animal beneath it, and the hunter follows with the large lance, which, when the seal re-appears, he throws as he did the harpoon. This he does again and again, the lance always disengaging itself, until the poor seal becomes so weak that it can be overtaken and killed by a Innge of the knife.

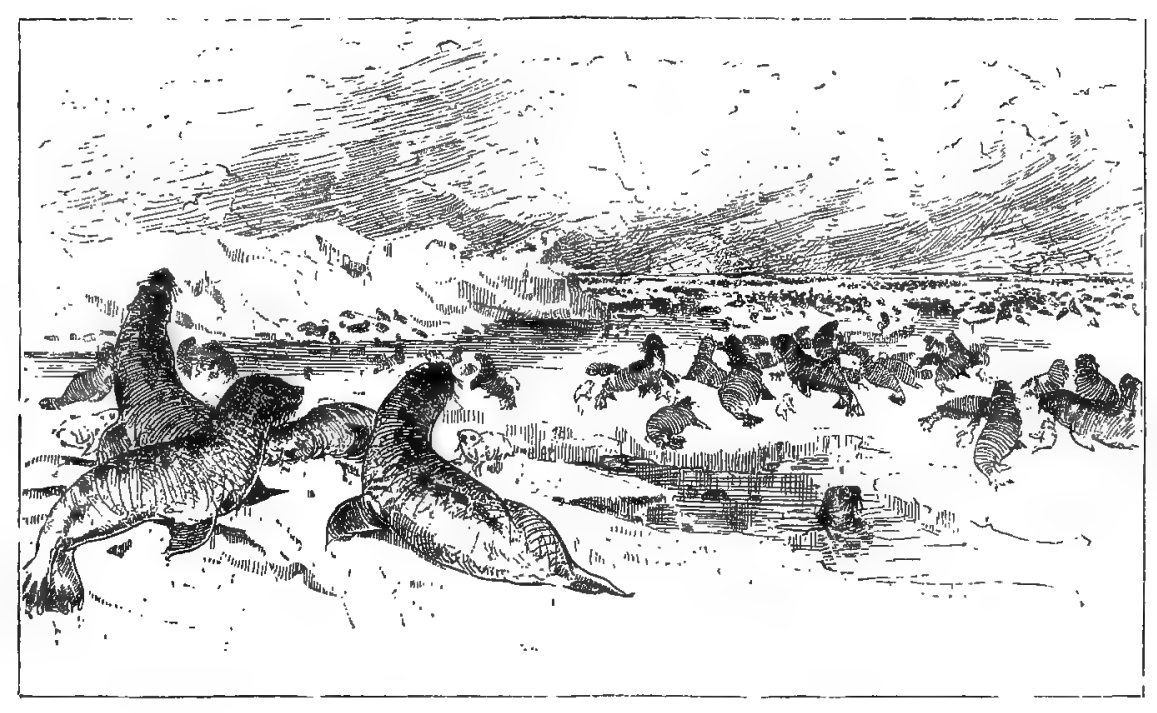

A "SEAL MEADOW," OR HEIRD UPON THE ICE.

The flesh of the netsick serves for food all through the summer, and is dried, or "cached" (i.e.concealed) in the snow, for winter use. From the skins of the old seals the arctic natives make their summer clothing, while undergarments are fashioned from those of the young netsick. Children often wear entire suits of the white skins of the baby seals in their first fuzzy coat. With the flesh and skins of the netsick, too, the Eskimo travels southward to the Danish settlements, and trades for such civilized articles as he is able to buy. 
Late in the summer, when the young seals have grown able to take care of themselves, and the herds are away enjoying the open sea and getting fat on the abundant food they find at that season, the Eskimo has to pursue them with great caution, crawling over the ice face downward, and imitating their awkward, tumbling play until near enongh to hurl his spear; or he must get into his frail kayak and chase the herds far up glacial fiords and away across the rough and chilling sea, where they are living on the floating ice.

The food of seals is various, but consists chiefly of fish, thongh the young ones, when companies of them first begin to lunt in the shallow water near shore, seem to like crabs better than anything else; and to several species of shrimps, abounding in northern seas, the observant sailors have given the name "seals' food." Shell-fish of various sorts, too, are cracked in their strong jaws and devoured, especially the arctic mussels. They swallow many pebble-stones also, not for food, but, it is supposed, in order to aid digestion.

Now I must force myself to leave this hasty sketch of the natural history of these most interesting and serviceable animals, regretting that I cannot dwell longer upon many of its features, and turn to the exciting incidents of the chase conducted against them every spring by ships and crews from America and Europe, the details of which present a horrible picture of blood and cruel warfare against one of the most innocent and child-like creatures that ever breathed.

The phocine seals of the Atlantic are not hunted for their fur, as are their Alaskan consins, but chiefly for their oil, and secondarily for their skins. It is an industry which profitably employs hundreds of ships and thonsands of seamen, and it receives the name of "sealing." The principal sealing-grounds are Newfoundland, Labrador, and the islands which lie between, but especially the ice-floes off the const of western Greenland; the Spitzbergen and Jan Mayen seas; Nova Zembla, the White and Caspian Seas. Of these districts the most important is Newfoundland, where, as long ago as half a century; three hundred and seventyfire vessels assembled annually, and, twenty-fire years ago, five hundred thousand seals were taken in a single season. These early fleets, which were larger in point of numbers than any that go ont now, consisted wholly of sailing vessels, many of which were of small size, notwithstanding the long and tempestnons royages they had to endure. The most of them hailed from Newfoundland. All these were concerned in "ice-hnnting," which is the most extensive and profitable, thongh 


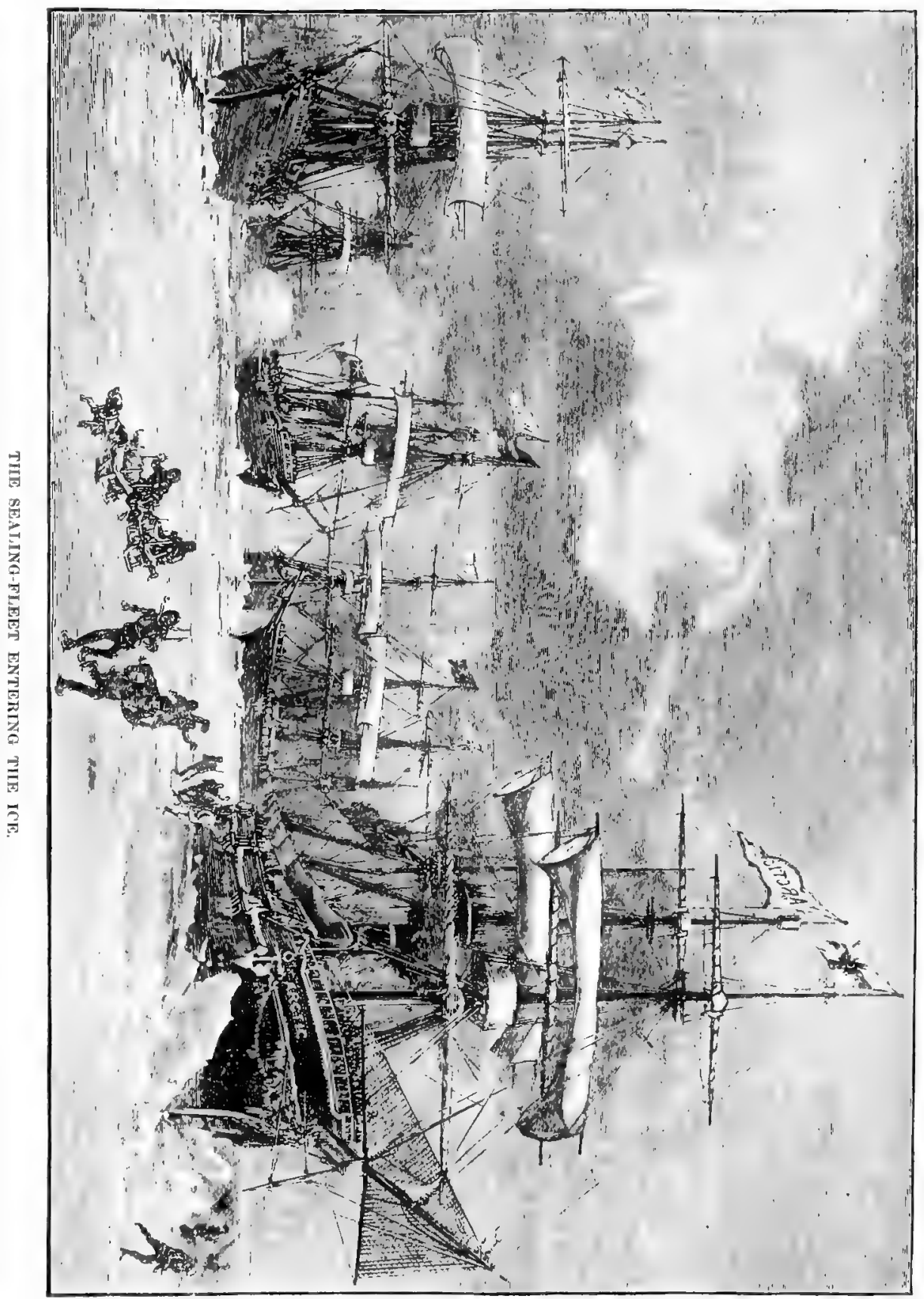



by far the most dangerons of all the methods in vogue for capturing seals.

You will remember that at the end of winter enormons herds, chiefly of the harp-seal, come down and congregate upon the floating fields of ice eastward of Newfoundland, where the young are born in March. The largest fishery occurs at that place and season, but the locality is never fixed nor certain; the fields, approached simultaneously by sailing fleets and steamers from Newfoundland, Nova Scotia, Scotland, England, France, Germany, and Norway, must be sought for every year as though for the first time. This is in the icy, tempestuons North Atlantic, at the most stormy period of the year. Dreadful gales may drive the ships anywhere.but where they seek to go, bergs may be lumled against them, the ice may jam them between its ponderous edges and crush the doubly braced hulls into splinters, or cleanly cut away parts of the bottom, leaving the vessels to sink and the men to save themselves as best they may upon broken and drifting ice. Strange to say, steamships are more liable to harm from the ice than sailing-ships, which will be lifted up instead of crushed. Often a field of thin "bay-ice," or a solid floe, will lie right in the path; then the ship dashes into it as far as its power can force it. When it can move no farther the erew leap overboard, chop and break the field into cakes which are shoved under the floe or hanled out on top; or, if it is too thick to be broken, saws are brought out, and a canal is slowly made for the ship's progress. This is a time of great desire for haste, and you may well believe that every man works with all his might.

"Sometimes," writes an eye-witness, "a crowd of men, clinging around the ship's bows, and holding on to the bights of rope... wonld jump and dance on the ice, bending and breaking it with their weight and dragging her on over it with all their force. Up to their knees in water, as one piece after another sank below the cnt-water they still held on, hurrahing at every fresh start she made-dancing, jumping, pushing, shoving, hauling, hewing, sawing, till every soul on board was roused into excited exertion."

Well, when all this toil and danger are passed-sometimes greatly prolonged, in the midst of a frozen sea and the most violent stormsand the ship lias the good-luck to sight a herd, then begins for the crew of hardy sailors a season of about the most arduous labor that one can imagine.

If the weather permits, the vessel is run into the ice and moored there; if not, it sails back and forth in open spaces, managed by the captain and 
one or two others, while the remainder of the crew, sometimes sixty or seventy, or even more in number, get into boats and row swiftly to the floe. The young seals are scattered about here and there, basking in the sun or sheltered under the lee of a hummock, and they lie so thickly that half a dozen will often be seen in a space twenty yards square. They cannot get away, or at most can only flounder about, and their plaintive bleatings and white coats might alnost be those of lambs. The old seals are frightened away by the approach of the sailors, and never show fight, while the youngsters are easily killed; so the men do not take guns, but only clubs, with which they strike the poor little fellows a single blow on the head, usually killing them at once.

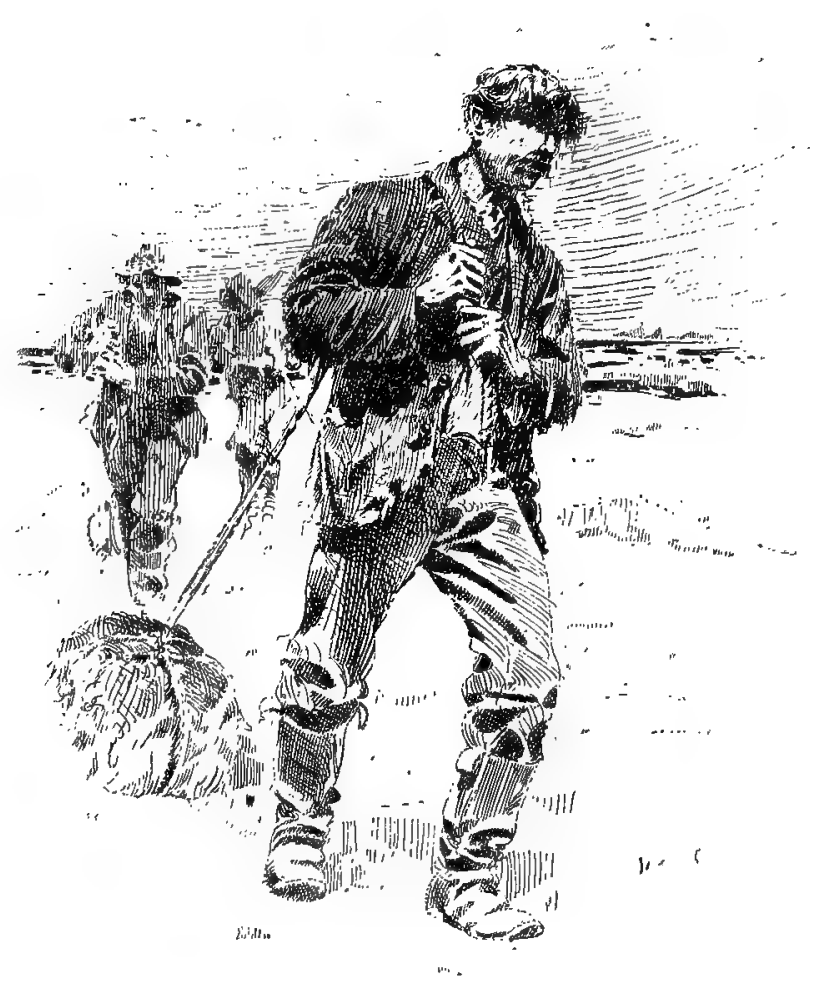

DRAGGING BUNDLES OF PELTS.

Having struck down all they can see within a short distance, the small squad of men who work together quickly skin, or (as they call it) "sculp" their victims with a broad clasp-knife, cutting clear through the thick layer of fat which lies underneath the hide, and so leaving a surprisingly 
small carcass behind. Bundles are then made of from three to seven "pelts," and each man drags a bundle towards the boat. This is sometimes miles distant, the ice is rough and broken, he inust leap cracks, trust himself to isolated cakes, and may often fall into the freezing water, or lose his way in a sudden squall of snow. It is limb-cracking and liferisking work, and to accomplish it successfully a man must school his muscles to endurance, his nerves to peril, and his heart to bitter cruelty; but every pelt is worth a dollar!

By night, after a "seal-meadow" has been attacked, the decks of the vessel are hidden under a deep layer of fat, slippery pelts. After these have lain long enough to get cool, they are stowed away in the hold in pairs, each pair having the hair outward. The hold is divided by stout partitions into compartments, or "pounds," in order to prevent the cargo from moving about and so rubbing the fat into oil, which would speedily fill every part of the hold and the cabins, spoiling all the provisions; a vessel once had to be abandoned from this accident becanse it had not been "pounded." The European ships, howerer, generally separate the fat at once and stow it in casks.

Sometimes, instead of bringing the pelts to the ship as fast as they are obtained, the hunters pile them up, placing a flag on the heap so that no other crew will take them, for there may be a score or two of vessels all attacking the herd at once; and this clain is respected. But in very many cases a snow-storm hides these heaps, or they break away from the floe, or the ice "jams" and crushes them, or the ship itself is driven too far off to return, so that they are lost or wasted; hence the practice of thus piling up the pelts is ceasing.

Perhaps I have given you the impression that it is only the young seals that are taken on these expeditions, but that is not whully correct. 'Two voyages ale ordinarily made, each lasting about two weeks. The first voyage brings home few old seals, but on the second voyage the sealers find the youngsters pretty well grown, and as well able to escape as the old ones. They must therefore use guns somewhat, and otherwise manage to secure adult or nearly full-grown seals, if they are to get any at all.

There are several methods of capturing these animals along the shore: by driving companies of them into nets set among rocks, or spread underneath the ice at their breathing-holes; by surprising them asleep on the shore and cutting off their retreat; by shooting, harpooning, and so on, all of which are exciting and picturesque.

Besides the skins and the fat, parts of the flesh are preserved for food, 
and those who are accustomed to it recommend it highly. The flesh is a "universal remedy" anong the Eskimos. When the Pandora left England on her arctic expedition in 1874, her interpreter, Joe, an Eskimo, had a bad congh, but he refused all medicine, saying, "Bimeby, eat seal, get well." And sure enough his coughing was heard no more after he had feasted on his favorite food for a few days. "For young ladies and gentlemen who cannot succeed in making their features sufficiently attractive on chicken and cheese-cakes, no diet is likely to succeed so well as delicate cutlets from the Join of a seal."

When a cargo of pelts has been brought home, the fat is carefully removed and converted into oil by exposure to the sun. The process may be hastened by the aid of steam, but oil thus produced is said to be poorer both for lamps and for the lubrication of machines. The skins are salted and packed, and become cured in three weeks, finding ultimate use as shoeleather, and as covering for knapsacks, valises, small trunks, etc.

In the North Atlantic alone the sealing gives employment every spring to, say, twenty-five steamers from Newfoundland, built expressly for the purpose, besides unnumbered sailing vessels; the crews of this fleet making a navy of about ten thousand eager young men. The starting is a scene of the greatest bustle, and when the men return with rich cargoes, and get their pockets full of money, there is great hilarity around the usually dull towns of that far northern island. It is said that in one year, recently, a round million of seals were taken in the North Atlantic alone. Yet there seems to be little or no diminution in the crowds that annually throng the ice-floes when March comes round. 


\section{XIX.}

\section{THE CAVERNS AT LURAY AND AT PIKE'S PEAK.}

THAT the underlying limestones of Page County, Virginia, were penetrated by crevices, horizontal cracks, and some caverns of respectable size, has long been known. The general valley of the Shenandoah is here badly broken up. At Riverton two streams unite to form the main river. Between them lies the Massanutton Mountain-an isolated range parallel with the neighboring chain, and dividing their water-sheds. Enclosed by it and the Blue Ridge, and drained by the South Fork of the Shenandoah, lies the Page Valley, with the small village of Laray, as county-seat, in the centre, on the Shenandoah Valley Railroad.

Page Valley is here several miles wide, and the surface is diversified by an endless series of knolls, ridges, rocky outcroppings, and deeply embedded streams. "The rocks throughont the whole of this region have been much displaced, having been flexed into great folds, the direction of which coincides with that of the Appalachian mountain-chain. In fact these folds are a remnant of the results of that series of movements in which the whole system primarily originated." Hidden in the woods near the top of one of these hills, about a mile east of Luray, an old cave has always been known to exist. Connected with it are traditions which reach back to the Ruffiners, the earliest settlers of the valley. Peter Ruffner the First was a Hanoverian, who married the daughter of a wealthy Pennsylvania farmer, and moved down into this wilderness, where he possessed himself of a large tract of land and raised fifteen children. His eldest son, Peter the Second, also got him a wife and fifteen children, so that the colonization of the valley proceeded with great rapidity. One of this first generation of Ruffners went out hunting one day and did not come back. At the end of nearly a week's search his gun and powder-horn were found at the mouth of this cave, within which the famished and nearly dead man was at last discovered. Of course nothing less could be done than to call it Ruffner's Cave, which is printed on all the maps in attestation of the truth of this history. 
Knowing something of this eave, in the summer of $1878 \mathrm{Mr}$. B. P. Stebbins conceived the project of a more complete exploration of it, with a view of making it an object of interest to tourists, and he invited the co-operation of the brothers Andrew and William E. Campbell. These gentlenen declined to go into the old cave, but were ready to engage in "s search for a new one, and it was finally agreed to form a "company" for that purpose.

Together they went ranging over the hills on both sides of the valley, across the fields and in and ont of the abundant and tangled.woods, examining every depression, peering into all the dark corners, stooping under rocky ledges from which the rattlesnake had first to be expelled, enlarging holes whence scared foxes darted in dismay or drew their skins into a minimum of bulk, hiding their bushy tails and skulking at the uttermost end of their half-natural burrow. They parted thickets only to find that they did not hide the coveted prize, which, nulike most objects of eager searching, would have an increased value in proportion to its hollowness! Nearly four weeks spent in fruitless search had their only effect in exciting the astonishment and ridicule of the neighborhood, when, returning one Angust day from a long tramp, the men approached home over the hill where Ruffner's Cave was. In the cleared land on the northern slope, a couple of hundred yards or so from the mouth of the old cave, was a sink-hole choked with weeds, bushes, and an accumulation of rails and loose stones, which, for generations back, farmers had been accustomed to toss in there out of the way. It occurred to them that this suspicious hollow was worth investigation. Clearing away some of the rubbish, they fancied they felt currents of cool air sifting up through. Laborionsly tumbling out the bowlders, Mr. Andrew Campbell was finally able to descend by the aid of a rope into a black abyss, which was not bottomless, however, for he soon let go of the rope and left his companions on the surface to their conjectures. Becoming uneasy at his long absence, his brother also descended, and together the men walked in a lofty passage for several rods, where their progress was stopped by water. Returning, they told $\mathrm{Mr}$. Stebbins what they had seen, and all agreed upon a policy of silence until the property could be bought. Then they went home and dreamed of "millions in it." Such was the discovery of the Luray Cave.

Dreams are but a "baseless fabric." The property was bonght of a bankrupted owner, at sheriff's sale, but upon an intimation of its nnderground value, one of the relatives of the original owner sued for recovery upon an irregularity in the sale, and after two years of tedions litigation, 
in which the case was carried to the highest conrt, he won his suit. Previously, a company of Northern gentlemen, most of them also interested in the local railway, formed a joint-stock company to purchase the property, and it passed into their hands in the spring of 1881. But during the two years the original cost had swelled, and the early visions had dwindled until they met at $\$ 40,000$. This is the history of the "wonder," and nuw we are ready to enter it.

The ground rises only a trifle from the level of the valley to the hill, and on the open slope stands a honse with porticoes all around, conspicuous in fresh paint, and having a public air about it. There is the ordinary appearance of public waiting-rooms about this house, bnt, unlike most houses, the great interest of it lies in its cellar. Registering your name, yonr gnide gives you a tin frame, much like a scoop-shovel, held upright by a liandle at the back, which holds in front three lighted candles. He opens an inner door, and you follow him down a staircase of masonry, and before you grasp the idca that your adventures have begun, you find yourself in the large antechamber of the caverns. This unpremeditated, unintentional entrance is as though you had been dropped in the midst of it, or had waked from a sleep there, and is most effectual in putting the stranger en rapport with the spirit of astonishment which he must feign, if (by reason of any sad defect in his constitution) it is lacking, in order to maintain his reputation in this locality as a respectable person. At the same time the truth is pressed upon your mind that this cavern is not in the side of a momtain, as your preconception of it would suggest, but underneath one of the low hills which diversify the surface of the valley, and which remain from the hollowing out of all the valleys, and the production of the mountains four or five miles distant on either side; and the cave "has no obvious relation with them, except that its origin was partly coincident with their origin, and with the excavation of the valley by erosion."

When the Campbells first entered this antechamber, which is abont as large as an ordinary barn, they were able to follow a narrowing extension of it only a little way, when, as I have said, they were stopped by water. Some weeks later, in order to make a second exploration, they took a small boat with them, but found that the water had nearly dried away. We can now walk across on a causeway of clay for twenty-five or thirty yards, past the Vegetable Garden, the Bear Scratches, the Theatre, the Gallery; over Muddy Lake on a planking bridge, which is itself spanned by a stone arch; through the Fish Market and across the Eltin Ramble-a platean in which the roof is grenerally within reach of the 
hand; and so come to Pluto's Chasm, an underground ravine roofed with the strata which support precisely similar gulches and chasms opening to daylight, and owing their configuration to the same slow and subtle agencies. Most persons, trying with their gaze to fathom a depth which their candles' beams fail to penetrate, but which, by-and-by, their feet lead them to, are tempted to exclaim, "What mighty convulsions rent these walls asnnder "' forgetting the unparted stratum of native rock overhead. But cataclysm, as the all-potent word to explain every hard conundrum of geology, is obsolete. As in the fable of the hare and the tortoise, an agency infinitely slower, a very type of gentleness, has done the same work while the convulsion slept.

Great caves can only occur in a limestone region, and they result from the chemical fact that the carbonates of lime and magnesia are soluble in water cuntaining carbonic acid. "This acid abonnds in atmospheric air, and is one of the products of the decomposition of animal and vegetable waters, so that rain-water which has percolated throngh the soil has usually been enriched with it from both sources. With carbonic acid, then, as the active agent, and water as the carrier, we are able to account for the disappearance of strata however thick, and whether above or below ground. Above gronnd the result is a lowering of the general level, the deposition of a residual stratum of clay (a constituent, in a finely divided condition, of the Valley limestones), and the formation of valleys where special causes have favored the disintegration of the stone. 'Har'd' water flows away, and a clay soil is left behind. Below ground, on the other hand, the result is a cave--if there be a fissure in the strata through which the acidified water nay make its descent. In the course of time this fissure is worn larger, and the entering water dissolves and bears away with it bit by bit the stratum through which it passes, flowing ont at some lower level with its burden of lime and magnesia, but leaving the clay behind to plague the adventnious cave-hunter."

Given the initiatory crack-common enough in limestones-and it only requires time and abundance of water to hollow out Pluto's and all the other chasms, halls, galleries, and aventues which make up this or a more extensive series of caverns; and when once this work has well begun, other natural agencies contribute their aid to the enlargement of the area and the adornment of its interior.

From the chasm, where there is a Bridge of Sighs, a Balcony, a Spectre, and various other names and habitations, we recross the Elfin Ramble, walk, wherever dry, on mud or tufaceous floor or ringing rock (when honeycombed, sonnding hollow beneath the tread), and in muddy 
or difficult places npon bridges of pine planking, which rots away and must be replaced every nine months. We pass successively Titania's Veil, Diana's Bath - the lady was not fastidious - and come to a very satisfactory Saracen Tent.

Then we ascend stairways past the Empress Column-easily empress of all, I think - and proceed under the Fallen Column to the spacions nave of the Cathedral. We panse to note its lofty groined roof and Gothic pillars-surely, in some like scene to this, the first architect of that style met his inspiration!-its large, Michael-Angelesque Angel's Wing, and its Organ. Then we sit down and turn to the prostrate stalactite. It is as big as a steamboat boiler, and bears an enormous pagoda of stalagmitic rock which has grown there since it fell. It thus forms a good text for a conversation.

Here Dr. C. A. White, of the Smithsonian Institution, stands as authority. The rock ont of which Luray Cavern has been excavated is a compact, blnish limestone, not very evenly bedded, and weathering ruggedly on account of its heterogeneous texture, a fact to which the almost endless variety and irregularity to which it chiefly owes its charm is largely due. The few fossils discovered indicate that this limestone stratum is of lower silurian, probably belonging to the Trenton period.

The position of the cave in the middle of an open valley, distant from the mountains, and so much below their crests, shows that it was hollowed out towards the close of the epoch within which the formation of the valley took place. The character of the erosion leads to the conviction that the excavation was effected subsequently to the formation of the great folds referred to at the beginning of this article, which plaiuly took place after the close of the carboniferous period, because strata of that period and those of later date are involved.

It is thus evident that the geological date of the origin of Iuray Cave, althongh it is carved out of silurian limestone, is considerably later than the close of the carboniferous period. None of the facts yet ascertained warrant a more definite conclusion concerning the limits of its antiquity than to say that the most recent epoch at which it might have been formed is the tertiary. It is highly probable that the date of its origin is not more ancient than that of the Mammoth Cave, or the Wyandotte in southern Indiana.*

Now these geological statements tell one the relative position which the cave occupies in cosmic history, but they help the mind little in 
comprehending its antiquity, measured in years or even by centuries, and serve chiefly to make our vaporing on the subject seem of extremely small acconnt. Nor can we get at a moch better estimate by studying the present processes of change, for evidently these have not gone on uniformly since the beginning - both erosion and new growth varying from year to year at every point, and proceeding in no two parts of the cave at exactly the same rate. The indications are, that in past ages the work went on with great rapidity, but that latterly change has been very slow, and at present has almost ceased.

Leaving the Cathedral, a narrow, jagged passage, where one must continually guard both his shins and his crown from painful bumps, we get an outlook down into a sort of devil's pantheon, full of grotesque shapes and colossal caricatures of things animate and inanimate, casting odd and suggestive shadows in whose gloom funcy may work marvels of unworldly effect, and leads you by a stairway to a well-curtained room called the Bridal Chamber. With an access of that idiocy with which the strongest people, perhaps, are tinctured when about to enter matrimony, one or two couples have come to this damp hole to be married; so the place is put down in descriptions as "consecrated!" The back door of the Bridal Chamber admits to Giant's Hall, just beyond which is the Ballroom - both large and lofty apartments, constituting a separate portion of the cave, parallel with the length of Pluto's Chasm. In the Ballroom we have worked back opposite the entrance, having followed a course roughly outlined by the letter $\mathrm{U}$.

I have thus run hastily over the greater part of the ground open to the public, in order to give an idea of its extent and nomenclature. To describe each figure and room separately is impossible. The best I can do is to try to give some general notion of the character of the ornamental formations of crystalline rock which render this cave without a peer in the world, perhaps, for the startling beaty and astonishing rariety of its interior. Some caves - the Mammoth is an example-are completed by the simple digging ont of their vaults; no subsequent growth of new rock supervenes to decorate their hard and changeless walls. There the sense of vast vacancy, of awful silence, of dreadful, lonely darkness, strikes the heart.with awe, and impresses the mind by its utter intangibility. Here there is nothing of the sort. Objects are near at hand, suggest familiar forms, and instead of vague terror you feel a comfortable and lively entertainment.

Where conditions of dryness and ventilation are favorable, and the percolation of water is just right, stalactites and stalagmites will form 
as they have done here, though rarely in equal profusion and attractiveness. Their formation is simple. Whenever, through some of the minute crevices in the limestone roof or wall, a drop of water trickles, it is sure to be saturated with carbonic acid, and to bear along with it a solution of lime and magnesia. When emerging from its rocky channel it meets with a current of air, it will evaporate and leave behind it minute crystals of carbonate of lime, deposited in the form of a ring, because, as the drop evaporated, the solid matter became more concentrated around its edges than in the pendent centre. "This ring now becomes the support of the drop, and the process continues until a tube of the diameter of the drop, and from one to thirty-six inches in length, is formed. At this stage of its growth it begins to fill ap, and the water now trickling exteriorly deposits its solid matter and enlarges it." This process forms a hanging appendage of stone exactly as icicles growlarge at the top, because the larger part of the lime is deposited before the drop reaches the tip, which nevertheless prolongs itself downward with never-ceasing endeavor to toueh bottom.

But, in the majority of cases, more water flows down a stalactite than can be evaporated, and drops to the floor, depositing, particle by particle, its solid matter in the same spot, directly underneath the tip of the stalactite, until a column corresponding fairly to the size of the stalac tite is built up; this is a stalagmite. In time the upward reach of the one and the downward stretching of the other may join them into a single column, thick or slender, reaching from floor to ceiling. There are many such pillars, seeming to support the roof, in this cave-hundreds of them, from the size of a fisling-rod (and wonderfully resembling a bamboo stick, with every node perfect) to that great column in the centre of Giant's Hall, which is fifteen or twenty feet in circumference and is ribbed like an ancient oak or redwood; pillars representing all sorts of architectural style in base and capital, for the sculpture-like growth and commingling of these stalactites and crystallizations lend themselves easily to every odd design and fantastic embellishment, which yet never seem inharmonious.

Thongh the simple stalactite will be circular and gradually decreasing in size, conically, from its attachment to its acuminate point, yet innumerable variations may occur, as the dripping or streaming water that feeds it is diverted from its direct and moderate flowing. Where it runs slowest, but copiously, or at least continuously, there most lime will be deposited, and the stony image will be built up to the prejudice of a less favored part. Thus it happens that stalactites often become expand- 
ed at their ends far beyond their size at the top, or take a slanting line; then the stalagmite underneath learns also to lean in the same direction, so that when they meet it will be at the intersection of two angular lines of growth. A notable example of this process is seen in the "Tara's Harp" and its snow-white feeder.

Chief of all the varieties, however, and the one that in lavish profusion is to be seen everywhere in these caverns, is that which, by growing on the edges only, produces not a round, icicle form, vertically pendent, but a wide and thin laminated or sheet form, which is best described by its semblance to heary cloth hanging in pointed folds and wrinkles, as a table-cover arranges itself about a corner. This is most likely to happen where the water flows over the edge of a ledge, or comes down through a crack rather than by percolation throngh needle-point apertures, or where it oozes from the side-walls. Now the heterogeneous nature of this limestone, mixing masses of harder or more gritty substances with other fractions of a softer kind, cansed it to be eroded unequally, and everywhere enormous angular masses, resting on a softer substratum, have been undermined until they fell to the floor, stood out from the walls as protrnding ledges, or were cut out from their connection with the wall-rock, and left standing as islands to be coated and reshaped and hidden away under the glittering panoply which the gnomes who did the work hastened to throw over every bit of common rock within their industrions reach. It is this channelling through soft rock and leaving hard limestone alone; this chipping away overhead and underneath a resisting stratum; this tumbling heedlessly down and sedulously piling up; this everlasting, tireless labor after grotesque change which is not yet, nor ever will be, content-these give to Luray its labyrinthine lack of shape, its chaotic mnltiplicity of things completed and things half done, and things not yet nore than mere material, which mark it to the imagination as a workshop, or a last hasty refinge, or an unarranged storehouse of the art-workers of the underworld, who, surprised by the light of intruding day and the inquisitive, commonplace eyes of men, fled affrighted to some yet more profound habitation in the depths.

Fancy has taken the bit in her teeth, as she is most likely to do down here; but what I started ont to show was, that where ledges and tablelike surfaces were so abundant, there the drapery was sure to form. In the Market it crowds the terraced walls in short, thick, whitish fringes, like so many fishes hung up by the gills_- "rock-fish" the guide will tell you, as his little joke. The Saracen Tent is formed by these great, flat, 
sharply tipped and gently curving plates, rich brown in color, depending from a square canopy so that they reach the floor, save on one side, where you may enter as throngh. conveniently parted canvas. The Bridal Chamber is curtained from curious gaze with their massive and carelessly graceful folds; the walls of Pluto's Chasm are hung with them as in a mighty wardrobe; Diana's Bath is concealed under their protecting shelter; Titania's Veil is only a more delicate texture of the same; Cinderella Leaving the Ball becomes lost in their folds as she glides, lace-white, to her disrobing; and a Sleeping Beauty has wrapped these abundant blankets about her motionless form; while the Ballroom carries you back to the days of the Round Table, for the spacious walls are hung as with tapestries.

Do not disbelieve me when I speak of wealth of color. The range is small, to be sure, but the variation of tint and shade is infinite and never out of tune. A painter would perhaps express it intelligibly to his bretbren by saying it was all a harmony in brown. The first crystals of these salts of lime are pure white and translucent. If you pick up a fallen fragment of a young stalactite, you find it a white, delicate tube, glassy without, spongy within, alabaster-like, and almost transparent. Where water is continuonsly flowing, and crystallization at present is going on with some rapidity, as at the various "frozen fountains" and "cascades" - which look precisely like the gleaming cataracts of sunlit ice that are to be seen on high mountains, or at Niagara in winter-the surface is crystalline, perfectly white, like fresh marble, only more radiant and ethereal, and sparkling with a soft, snowy light. Such is the lofty and richly chased Empress Column, the Geyser, the odd little Comet, the Spectre that gleams fitfully from the stygian gloom of a seemingly boundless abyss, a thousand alabaster pinnacles and pendants scattered here and there, and much silvery fretwork on wall and monument. But when the steady growth ceases, and fresh crystals no longer supersede with maiden purity the débutantes of yesterday, then the carbonic moisture of the air eats away the glistening particles of lime, and leaves behind a discolored residuum of clay-dust and iron oxides. If this has gone on very long, the object attached becomes almost completely decomposed; you may push your penknife to its hilt into the apparently adamantine substance of the Fallen Column. Thus it happens that, from the niveous purity or pearly surface of the new work, there runs a gentle gradation through every stage of yellowish and whitish brown to the dun of the long abandoned and dirty stalagmite, the leaden gray of the native limestone, or the inky shadow that lurks be- 
hind. It is thus that the draped and folded tapestries in the Ballroom are variegated and resplendent in a thousand hues. Moreover, various tints are often combined in the same object, particularly in the way of stripes more or less horizontal, due to the varying amount of iron, silica, or other foreign matter which the lime-water contained from time to time.

The best example of this, and, indeed, of the "drapery formation" generally, is to be found in the Wet Blanket-a name given apparently to dampen enthusiasm beforehand, that the eye may enjoy a fresh surprise. Suspended in a recess in the wall of a small sub-cavern is this curious stalactite, which perfectly simulates a blanket hung up after a wetting, every wrinkle natural to a dangling piece of heavy woollen cloth being represented, as though the water were yet draining out of it.

Down in Pluto's Chasm, also, is a notable group of stalactitic draperies. "They are sixteen alabaster scarfs," says a recent description, "of exquisite color and texture. Three are snow-white; thirteen, like agate, are striated with rich bands of every imaginable shade of brown, and all are translucent. The shape of each is that of one wing of a narrow lambrequin, one edge being straight, the other meeting it by an undulating curve. The stripes follow the curve in every detail. Down the edge of each piece of drapery trickles a tiny rill, glittering like silver in the lamplight. This is the ever-plying shuttle that weaves the fairy fabric." A balcony has now been built right among them, overlooking the Chasm, and this point should by no means be missed. The burning of magnesium tape here brings out, with the suddenness and spectacular effect of the ballet-stage, a thousand grotesque shapes and fanciful outlines, leaving spaces of darkness between where the eye nervously suspects that frightful creatures abide. "The devil !" exclaimed a startled guide, not long ago, as, halting for a moment, his lights were snddenly overturned by a gaunt form which shot by his feet; but it was only a hare. Wood-rats, mice, and bats are occasionally seen. There are no snakes, as one timid lady was afraid there might be, and the imagination is left to evolve the uncanny beasts out of the dens of darkness, which hold no life in reality beyond a few groping insects.

I have said that the edges of fallen rock-masses and ledges are clothed with the drapery-stalactites. This works curious results here and there in the cave, for two masses may be joined together, or, previously connected by an overlapping bridge-stone, may both be surrounded by stalactites which thus enclose an open centre, and bear a forest of stalagmites on top. A large number of the pillars are probably hollow, and are formed by the crowding together of many drapery-stalactites, which tinally have coa- 
lesced, leaving the pillar deeply fluted, or seamed up and down, along their connected edges. When you find one of these massive, ribbed, and rugged pillars vanishing above in a host of curved stalactites, their thin and wavy selvages guiding the eye to tips which seem to sway and quiver overhead, it is hard not to believe it is an aged willow turned to stone. Indeed the whole scene, in many parts, is strongly suggestive of a forest with tangled undergrowths, thrifty saplings, fallen logs, and crowding ranks of sturdy trees, under whose bending limbs and drooping foliage one might wander for miles without catching the flicker of a leaf or hearing the stir of any breeze-

\section{"The island valley. . .}

Where falls not hail or rain or any snow,

Nor ever wind blows loudly."

In more than the general effect, indeed, the ornamental incrustations of this cave mimic the vegetable growths ontside. Many of the stalactites are embroidered with small excrescences and complicated clusters of protruding and twisted points and flakes, much like leaves, buds, and twigs. To these have been given the scientific name of helictites, and they are ascribed "to a slow crystallization taking place on a surface barely moist, from material conveyed to the point of growth by a capillary movement." The grottoes of Stebbins Avenue exhibit them to the best advantage.

Then there are the botryoids-round and oblong tubers covered with twigs and tubercles, such as that cauliflower-like group which gives the name to the Vegetable Garden; these grow where there is a continual spattering going on. A process of decomposition, dissolving out a part and leaving a spongy framework behind, furnishes to many other districts quantities of plant-semblances, that you may name and name in endless distinction. Then, in the many little hollow basins or "baths," and in the bottom of the gorges where still water lies, so crystal clear you cannot find its surface nor estimate its depth-where your blue magnesium-flame opens a wonderful new cave beneath your feet in the unrecognized reflection of the.fretted roof, and where no ice is needed to cool nor cordial competent to benefit the taste of the beverage-there the hard gray stone blossoms forth into multitudes of exquisite flowers of crystallization, with petals rosy, fawn-colored, and white, that apparently a breath would wilt. Have you seen a group of sea-anemones in some tide-pool, with all their downy tentacles flung out? That is like these motionless corollas of calcite.

Another freak of crystallization is the making of "cave-pearls." They lie, three or four together, in little hollows in the floor, exactly 
like so many eggs in a sparrow's nest. Around a grain of sand or flint, as a nucleus, accumulates a concretion of lime. Every falling drop moves the grain and prevents its becoming attached or growing into any except a globular form; thus, under the propel circumstances, narbles or "pearls" are formed.

But I must cease this attempt at even a suggestion of the possible variety of size and shape, mimicry and quaint device to be met with in this cavern.

That hard stone shonld lend itself to so many delicate, gracefnl, airy shapes and attitudes, rivalling the flexible flower of the organic world, fills the mind with astonishment and bewilders the eye. And when you have struck the thin and pendent curtains, or the "pipes" of the Organ in the Cathedral-for these are only a group of stalactites which have fallen and partly buried themselves upright in the mud-and have fonnd that each has a rich, deep, musical resonance of varying pitch, so that with a little study you could complete the octaves and thrum a melody whose tones would be more like the breathings of an organ than the metallic quality of piano or xylophone-then your admiration is complete; the denizens of the cavern not only pose but speak. And how many, many centuries has this musenm, or gallery of the "playfulness of God," which the old geologists used to talk of, been patiently awaiting its disclosure! It is not a place for thousands of lights and the chattering merriment of excursionists, with their flirtations and junketing, but for silent and full-hearted delight.

The impressions which it all makes upon such visitors as are affected at all beyond ohs! and ahs! if written down, would form very curious reading. Of the hundreds that walk singly through these catacombs, or troop after the brass band of an excursion, few have left any record by tongue or pen; but the two best remembered by the managers about sum up the whole range of mental experience here. Both, curiously enough, were uttered the same day. The first visitor, after a long tramp, turned to Mr. Corson, and speaking slowly and impressively, said, " $\mathrm{I}$ feel as though I must kneel down and render homage to my Creator for this exhibition of infinite power." As the strong magnesium-light lifted the curtain of thick darkness in the Ballroom, and brought ont in an instant the far-reaching, coruscant, theatrical sculpture of the lofty dome, the silence was broken by the exclamation of the second spectator" "It knocks thunder out of the Black Crook!"

The cave has not yet years enough to have gathered about itself much human interest; but before leaving we must not forget to follow down 
a long stairway into a deep and narrow gulch, where the dampness and gloom is little relieved by anything to please the eye. At the foot of the staircase the guide drops his lantern close to a trench-like depression, through which a filmy brooklet trickles noiselessly. No need of interrogation-there is no mistaking that slender, slightly curved, brown object, lying there half out, half embedded in the rock, with its rounded and bi-lobed head, nor its grooved and broken companions. They are not fallen, small stalactites; they are human bones. Fit for the mausoleum of emperors, what a vast vault to become the sarcophagus of one poor frame! But the cave has guarded its trust well, for, while Cæsar's bones have "turned to clay," these are durable as iron.

It is remembered in the valley that, half a century ago, a dwarf lived here, and one day disappeared from view. Six or seven years afterwards his gun and shreds of his overcoat were discovered in the woods near the entrance to the old cave, whereupon it was concluded that he had entered and lost himself. However, the fact that additional parts of the skeleton are still buried underneath the tufaceous floor seems to disprove the theory that these are the poor dwarf's bones, since more than half a century, or a whole one, would be needed to deposit stone enongh to entomb the bones, unless we discredit the evidence of the present slow growth of lime-rock in the cavern. Perhaps the owner of the femur, etc., was some Indian youth, who, three or four hundred years ago, by accident or design, entered these catacombs, and falling over the high precipice and unable to move starved to death.*

In animal and plant life also this cave is singularly deficient, all of Kentucky's and even the neighboring Virginian caves furnishing a far greater variety. Small spiders are numerons, but all seem to belong to the single species Linyphia Weyeri. There are occasional examples of oue of the cave flies; the myriapod spirostrephon Copei (Packard), which occurs in all the caverns of that region; and a new species peculiar to this cave, which has been named Zygonopus Whitei by Ryder, who described it in the Proceedings of the United States National Museum, vol. iii., p. 527. Previous to receiving living examples, Professor Ryder had obtained supposed specimens, which, upon being subjected to a test with acetic acid, proved to be only a calcareous crust that had been

* Mr. S. Z. Ammen, in his excellent little guide-book, calls these "the bones of a man -unhappy not to have possessed a copy of this book when he entered upon his explorations." My unhappiness, on the contrary, arose from the fact that I did possess it ; for I found it had preempted all my adjectives, particularly that widely serviceable term, "weird." 
deposited over dead insects lying in the cave. "These... were interesting as showing how psendomorphs of organic forms might be developed in caverns."

Both of these species of myriapods are blind, althongh seven other closely related species have the power of sight, which leads Professor Ryder to make some cautious remarks, a part of which I am persuaded to quote:

"In the absence of proof to the contrary, with the increase in the number of known blind forms which are often congeneric with lightloving species, there is the strongest kind of ground for supposing that they have descended from forms which had eyes, and which wandered into these recesses, where, after many generations had lived and died, a blind form appeared, which resulted from the gradual abortion of the visual organs of its ancestors. In proof of this we have the partially blind Orchesella, which now seems to be verging towards snch a condition. In the absence of a greater number of facts we are not justified in inferring more. True, we have a few instances among mollusks, some of which in their larval states have useful eyes, but which afterwards become useless and abort as the shell develops and gets thicker. Some terrestrial myriapods are blind, such as Eurypauropus; so is Lumbrious, the earth-worm, and some of the dirt-abiding Thysanura, which also live among fallen leaves, such as Campodea; while in the burrowing Symphyla (scolopendrella) the eyes are rednced to a single pair, with little or no red or dark coloring in the tapetum, differing widely in this respect from the compound-eyed terrestrial myriapods."

A few bats and fewer rats make the entrance portions of the cave their retreat; and there seems to be no aquatic life in the pools, which nowhere form a stream communicating with the outer world so as to admit such denizens as the strange blind fishes and crawfish found in the Mammoth Cave. The vegetation is chiefly, perhaps wholly, represented by a long white mould which collects npon the under side of the green planks taken into the cavern for walks and stairways, and hangs like Spanish moss in quaint imitation of the ponderous stalactites overhead.

Out into the warm, sweet air again, all the world looks fairer for one's temporary occultation. Surely the Troglodytes had a hard lot. Even the Naiads nnder the water, and the Nereids, though indissoluble from growing trees, were better off!

Subsequent to my visit to the eaverns of Luray, I inspected a cave near Manitou, Colorado, which proved to bear a striking resemblance to 
the Virgiuian cave, and merits a word or two of description. This one is called the Cave of the Winds, and is distant from the Maniton Spa just a pleasant walk up Williams's Cañon, one of the prettiest of the gorges seaming the base of the great peak. The cañon walls are limestone, stained red and Indian yellow; they are lofty, vertical, and broken into a inultitude of bastions, turrets, pinnacles, and sweeping, hugely carved façades, whose rugged battlements tower hundreds of feet overhead against a sky of violet. At their bases these upright walls are so close together that much of the way there is not room for one carriage to pass another, and the track lies nearly always in the very bed of the sparkling brook. You seem always in a cul de sac among the zigzags of this irregular chasm, and sometimes the abundant foliage, rooted in the crevices above, meets in an arch across the brightly painted but narrow space you are tortuously threading.

Half a mile up the cañon, at the end of the roadway, a trail goes by frequent turnings about three hundred feet up the precipitous sides of the ravine to the foot of sheer cliff. Floundering in snow up this steep and slippery goat-path, we arrived breathless underneath an archway of native rock, giving access to a great chimney rising above a niche which serves as anteroom. The cave proved a labyrinth of passages, occasionally opening ont into chambers of irregular size (and rarely with very high ceilings), into which protruded great ledges and points of rock from the stratified walls, still further limiting the space in which it is possible to move about.

These passages are often very narrow, and frequently you must stoop in crowding through, or, if you insist upon going to the end of the route, squirm along, Brahmin-like, on all-fours for several rods at a time. The avenues and apartments are not upon the same level, but run over and under each other, and constantly show slender fox-holes branching off, which the guide tells you lead to some stygian retreat you have visited or are about to see. Boston Avenue is one such passage, partly artificial, between Canopy Hall and another large chamber, originally separated at that point by a thin wall of clay. Chicago Avenue is another side-squeezing but very pretty channel which forms part of the regula]" four hours' walk through the cave; for if one is to "do" the whole of the nearly one hundred chambers already discovered, it will take him fully that length of time. Often the end of one of these tortuous nuderground crevices, or passage-ways, is found in a round sink, like one of the great "pot-holes" sometimes occurring in a river-bottom, and the like of which I have never seen in any other cave. Many of the pro- 
truding ledges, especially in Canopy Hall, are thus perforated, and the guide will say that they were ground out by revolving pebbles; but it is easy to show the error of this, and demonstrate that the slow action of water and the atmospheric agents that have cut the rest of the cavern are also responsible for the "pot-holes." Instead, there will sometimes yawn at your feet, in a way likely to startle you, a squarish chasm, or the path will end in the side of a vertical chimney, seeming endless as you attempt to make your candle-beans penetrate the thick darkness which fills the shaft above and below.

Through several such chimneys or shafts you follow your guide in climbing long ladders or stairways up to a higher or down to a lower level. Clinging to the spidery supports with only a little halo of light about you, both ends of the ladder or the slender bridge hidden from view, and thus apparently unsupported, you thrill with a sense of romantic peril, and take extraordinary interest in what the guide is telling of his first exploration of this subterranean maze, when there was no route to be followed, nor even a ladder to assist his going about; you wonder more and more not only how such a labyrinth ever was explored, but how its passages can be remembered even with daily practice. I can best picture the tortuous complexity of underground shafts and tunnels, cracks and crannies, by asking you to imagine the atmosphere a solid, and yourself some pygmy following the tangled and criss-crossed interior of the thickly branching twigs of a tree. However, in remote portions of the cave, there exist very large rooms. One of these is two hundred and fifty feet long, and of varying width. Another would be large were it not encnmbered by fallen masses and by drip-stone pillars which are vertically ribbed. A third room, the biggest of all, measures four hundred and fifty feet in length, and is wide at each end, but narrows, hour-glass fashion, in the middle. The ceiling of this chamber is so high that no candleflame, or even magnesinm-light, has ever been strong enough to bring it into view, and the echoes are remarkable. In the greater part of the cave, however, one must contiuually stoop and dodge to avoid contact with the sidewalls or the ceiling.

It is to the ornamentation that I wish particularly to call attention. This exactly resembles that at Luray, except that it is upon a much smaller scale; the largest drip-formed pillars in the Colorado cave are said to be not more than twenty feet in height, and few in number. Both stalactites and stalagmites are small, and hang in rows from overhanging ledges, like icicles on eaves in winter. There are also few stalagmites, showing that generally the dripping has been sufficiently slow to allow 
of the evaporation of all the water before it accumulated in too heavy a drop on the tip of the pendant that its burden of lime was building out.

This varied greatly, however, in different parts of the cave; some rooms, for example, those near the entrance, are almost utterly bare, or adorned only with fungoid tufts of pure clay, which remained after the solid matrix had disappeared. On the other hand, so profuse had been the discharge of water over several ledges that the native rock is wholly concealed under a great "frozen cascade" of deposited material-alabaster-white, crystalline, sparkling - which well simulates ice. Elsewhere there is abundant proof that the water dripped rapidly and spattered, producing those curious botryoidal cauliflower-like masses called "vegetable gardens." This was like Luray, as also was the tendency observable everywhere-though rarely well carried out-towards the curtain or ribbon-like "drapery" form of stalactite, whose gracefully pendent corners make the Virginia cavern so strangely attractive. Much less wall-rock and ceiling is hidden under these water-built accretions, however, here than at Luray-showing, probably, that at no time was there so much water present in the rocks as found its way through the Virginian catacomb. The relatively smaller size of all the excavations at Manitou would confirm this explanation of a condition which might be expected in this dryer climate and superior altitude.

In one respect this cave far surpasses in beauty its Eastern prototype. The floors of many rooms are laid several inches deep with incrustations of lime-work, which is embroidered in raised ridges of exquisite carving. Again, where water has been caught in depressions, these basins have been lined with a continnous, crowding plush of minute lime crystals, like small tufted cushions of yellow and white moss. Such depressed patches occur frequently; moreover, the rapid evaporation of these pools, in confined spaces, has so surcharged the air with carbonated moisture that particles of lime have been deposited on the walls of the pocket in a thousand dainty and delicate forms - tiny stalactites and bunches of stone twigs - until you fancy the most airy of milleporic corals transferred to these recesses. Here often the air seems foggy as your lamp-rays strike it, and the growing filigree work gleams alabaster-white under the spray that is producing its weird and exquisite growth. In this form of minute and frost-like ornamentation, to which the most skilled work of the silversmith would bear no comparison, and where the flowers of the hot-house, or the brilliantly tentacled dwellers in some sunny tide-cove would find their delicate beauty surpassed, this Colorado cavern excels anything I know of anywhere. 
The most profusely ornamented part of the cave is that included in Music Hall, Alabaster Hall and Grotto, the Bridal Chamber, and the Dining-room. Music Hall, a chamber fifty feet long, with a level floor, even sides, and a high-arched ceiling, takes its name from the musical tones produced by gently striking the resonant, vibratory stalactites. Quaint imitative devices occur in the abundant excrescences here, while one end of the hall is a perfect little jungle of stalactites and stalagmites. Many of the specimens here do not taper, but have grown from their interiors by the water which trickled through, leaving snccessive rings at the mouth of the slender pendent tube, are of exactly the same diameter throughout, and, having grown rapidly, have not had time to waste into the clay-stained condition of the older formations, but remain beatifully translucent, as you may see by holding your yellow candle-flame behind them. Alabaster Hall and the Grotto are treasure-nooks, lavishly ornamented in every pattern of cave art.

I have said enough to show, I think, that in the Pike's Peak cave, which seems to belong to the same geological age as its eastern type, the conditions of excavation were substantially the same as in the Virginian "Wonder," and that consequently the same kind of spaces in the limestone rock are found in both, and the same sort of interior decoration: with this important difference, however, that the far greater supply of water in one has carved out vastly more spacious rooms, and furnished the transportation for an immensely greater mass of material into the secondary formations of both pendent and piled up drip-rock. 


\section{$\mathrm{XX}$. \\ THE ABALONE AND ITS UTILITY.}

PROBABLY of all the "shell-fish" of the Union, after the oysters, 1 clams, and the scallop, none holds a more important place commercially than the ear-shells, or abalones; and if edible properties are not made the scale of jndginent, then they hold the first place. The earshells belong to the conchological genus Haliotis, and there are nearly a hundred species of them scattered abont the world, our own Atlantic shore being almost the only coast where the haliotis is not represented. In many countries the flesh of this animal is eaten, and everywhere its shell is highly valued.

In Europe one of the localities most populons in haliotis is the Channel Islands, where they are called "ormer shells," said to be a corruption of the French oreille de mer; perhaps the popular name seen in the books of old English writers, "Norman shell," is equally a transformation from the French. Jeffreys says that the Cherbourg fishwomen call them "six yeux" (six eyes), from an idea that the orifices in the shell are real eyelets or peep-holes. "Venus's ear" and "sea-ear" are names derived from the

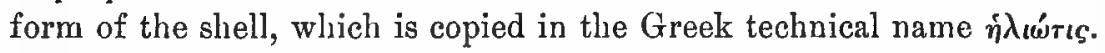

"The people of Guernsey and Jersey," says Simmonds, in his Cornmercial Products of the Sea, "ornament their houses with the shells of the ormer, disposing them frequently in quincunx order, and placing them so that their bright interiors may catch the rays of the sun." Could any decoration or frescoing be prettier, albeit somewhat grotesque? Not content with this, the farmers hang bunches of then on top of poles in their grain-fields to dangle abont and shoot lances of reflected light from their scintillating surfaces at timid but thieving birds.

In southern California the gathering of haliotis affords employment to a large number of persons, and a considerable commerce has sprung up. There the mollusk is called "abalone" - a word of donbtful SpanishIndian derivation, apparently having reference to the beads which Indians were wont to fabricate from this shell. The business is chiefly in the 
hands of Chinese, and that it shonld be so is very natural. At home the Chinese were, and yet are, accustomed to dry the flesh of their own haliotis (which is abundant from Malaya to Kamtchatka) as a food luxury. Finding in California practically the same mollusk, they at once began to gather the abalones for the sake of the meat, the surplusage of which they dried in salt, and shipped home to China at a good profit. After a time white men began to pick up the shells thrown away, and to work them over into ornaments and objects of jewellery. Thus apprised of their valne, the Chinamen also saved all the shells they got, and soon found this half of the catch brought more money than the dried flesh. For three or four years past the business in these shells has been extensive, but fears are felt that the mollusks may soon become exterminated.

The abalone producing region extends from San Francisco to Lower California, San Diego being the principal depot ontside of the capital, receiving stock largely from Mexican waters. For a long time Mexico paid no attention to this trespass upon her shores, but now she charges a license duty upon every abalone boat from the United States.

Abalones thrive best among rocky, weed-grown crags or reefs alternately exposed and submerged with every tide, and in a warm climate. They are not carnivorous, but subsist upon the sea vegetables, of which there is always an abundance in such places. Their fleshy base, or "foot," upon which the conrex, ear-shaped shell is carried, concealing and protecting the vital organs, is "very large, rounded at the ends, and fringed with thread-like tentaculæ, which, when the animal is protruded from the shell below the surface of the water, are gently swayed."

They move very little, and with great moderation of gait. The broad muscular foot is adapted less to locomotion than for adhesion, and so strong is the force with which they cling to the rock-withdrawing their protracted lobes, and squatting flat down at the least disturbance-that often it is exceedingly difficult to detach them, even with the aid of the trowel or spade which is usually carried by the fishermen. Another method is to pour over them a small quantity of warm water, and then give a sharp push sideways with the foot. The warm douche surprises and disgusts them into relaxation.

There is a grisly yarn (now of respectable antiquity) about a poor Chinaman who discovered a large abalone left bare by the tide, and partly exposing its mantle-lobes beneath the edge of its shell. The man had no spade or hot water with him, but atternpted to tear the mollusk up with his bare hands. No sooner did the abalone feel his touch than it shut down, pinching the Celestial's finger's between its shell and the rock so 
tightly that he could not pull them away before the tide, advancing with crnel speed, had drowned the poor wretch in the creature's relentless clutch. Whether or not this be an "ow'r-true tale," it well illustrates the strength with which the haliotis holds to its site-a power of anchorage needed when storms beat npon its native reef with almost resistless force.

The tenacity of life in this mollusk seems equal to its hold upon the rocks. R. E. C. Stearns, of San Francisco, writes that he has frequently removed the animal from the shell by means of a sharp knife, and thrown it back into the water, when "it would at once descend and place itself in its normal position upon a rock, to which it would adhere with apparently as much tenacity as before it was deprived of its shelly covering."

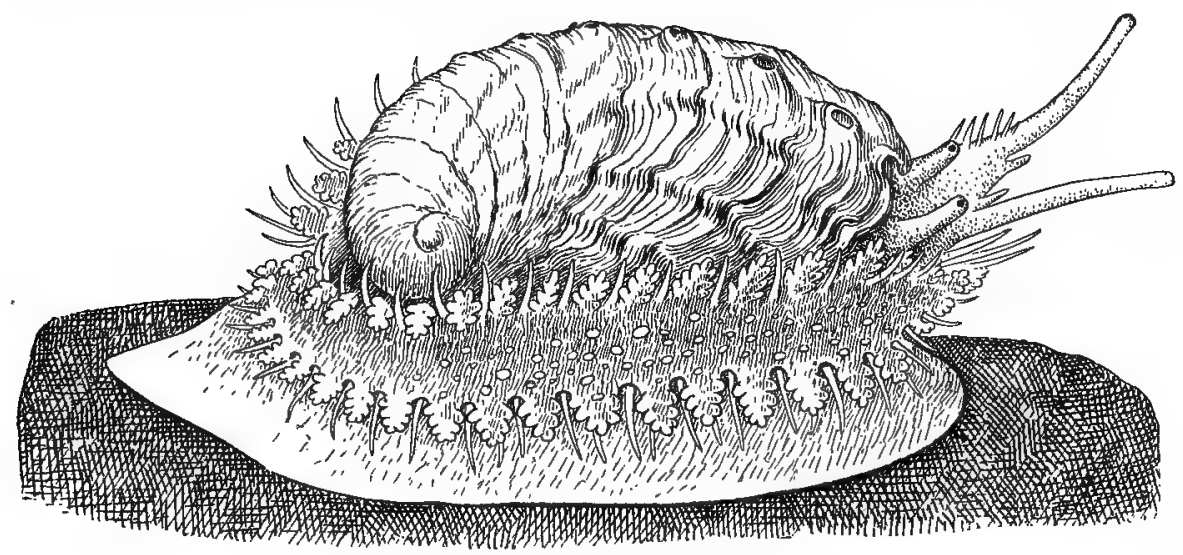

THE ABALONE, FULLY EXPANDED.

The flesh of the abalone has long formed an article of food in various parts of the world, such as the Channel Islands, France, along the Mediterranean (where they beat it to make it tender), Senegal, the South Sea Islands, Malaya, China, Japan, and our Pacific coast. It was described by old Athenæus, centuries and centuries ago, as "exceedingly nutritious, but indigestible," and holds its reputation well. A gentleman who lately ate it in Japan said his first mouthful seemed as tough and tasteless as so much india-rubber, but that presently the morsel dissolved into granules and could be swallowed, developing a flavor not unpleasant. Mexico exports it to us under the Custom-honse heading, "dried oysters." In San Francisco and the coast towns it is rarely eaten except by Chinese, who are the only ones that gather it. A simple process of salting and drying is all that is necessary for its preservation, in which shape it is sent to China. In order to get a ton of meat, about six tons of living 
animals must be collected, but there is no telling how many individuals this represents. After being cured, abalone meat is worth from five to ten cents a pound, and the value of the crop which reaches San Francisco annually approaches $\$ 40,000$, distributed among some hundreds of men. The coast is now so stripped of the haliotis that the Chinese fishermen are compelled to resort to unfrequented islands, transportation to which is afforded them by Americans, who take their pay in shells, while the Chinese retain the meat.

The trade in abalone-shells, indeed, is of twice as much importance, financially, as that in the flesh, since it amounts to nearly $\$ 90,000$ a year. Some Americans also are engaged in this business, and the finishing off of the shells for market is wholly in their hands.

The shell of the haliotis is one of the most brilliantly beautiful in its interior of any known. The lustrons, iridescent curves of the nacre, reflecting ever-varying and prismatic colors in endless profusion, delight every eye. In aged specimens the part to which the adductor muscle is attached is raised above the level of the rest of the interior, and presents a roughened or carved surface of irregular shape, often fancifully imitative of some other object. The writer has seen one which thus contained a singularly colrect profile or medallion of Napoleon I.

Eastern ingenuity, combined with the close observation which in some directions make the Chinese and Japanese eminent, has cleverly utilized the extraordinary power of secreting nacre possessed by this mollusk. It was observed that whenerer a grain of sand or any other small foreign substance worked its way between the shell and the mantle, the mollusk would speedily cover it with a pearly coat. This is the origin of pearls; and all bivalves do the same thing, but few are so large or supply the pearl so copiously as does our subject.

It occurred to the ingenious Chinaman that if he were to slip small figures of his own making underneath the abalone's armor, he could presently take them away beautifully empearled. This has often been done in the past and present; and priests have advanced theil doctrines in the faith of simple peasants by prodncing in this way (which they did not explain) pearl images of Buddha and other saints, and selling the same at a high price-advertising them as Nature's signets, miraculously impressed in divine attestation of the truth of their creed.

Outside, the shells are nsually rough and unattractive, except to the marine zoölogist, who finds them supporting a small forest of minute vegetable and animal forms, and harboring microscopic life of great interest. A curious case of a larger parasite is mentioned by Mr. Stearns, 
where a haliotis had been attacked by another mollusk-a boring bivalve known as Navea which had cut its way through the shell. Advised of this enemy, the haliotis had defended itself by adding coating upon coating of nacre as a bulwark between him and his foe, until, as the Navea progressed, a large knob was built in the interior of the abalone's shell.

The shells are usually sent to San Francisco from the lower counties of California in the rongh, and are the means of considerable speculation among coasting captains. The price paid for them by merchants varies greatly; an average at present would be $\$ 50$ or $\$ 60$ a ton. From San Francisco they are shipped botlı to China and to the Eastern States. In China they are broken up and used for inlaying in connection with the lacquer-work for which the Chinese are famous. The mosaics of Errope are often adorned by the same means, and various arts are served by their glittering fragments. It was with pieces of this sort of shell that those wonderfully beautiful inlaid screens from Holland, representing moonlight landscapes, etc., which attracted so much attention at the Centennial Exhibition, were produced.

Many of our shells are sent to Europe, there to be polished with the help of acids until they shall be as lustrous outwardly as inside, and then are reshipped to the United States to serve as mantel ornaments, soapbasins, match-boxes, card-cases, receptacles for flowers, etc. The same work is done to some extent in San Francisco, and many are there manufactured into gold-mounted ear-rings and brooches, shawl-pins, and various toilet articles, particularly ladies' ligh hair-combs of great costliness, if not invariably of equal elegance.

One dealer, also, at San Diego, California, polishes these shells himself, and sells them to tourists for from twenty-five cents to five dollars, or sends them to the East by mail in "nests" of four to six. The young of one sort are cleaned with the aid of hydrochloric acid, but the usual method with aged shells is to grind away the epidermis by hand by rubbing upon stones. It is too delicate work to trust to machinery, lest holes should be made in the thin pearly underlayers.

A peculiarity of haliotis shells is the line of four to ten round holes álong the ridge at one side. It is through these apertures that the mollusk gets the fresh water necessary to its breathing when it sits close down upon a rock, and when none can flow in under the edges of the tight shell. A similar provision exists in the "key-hole" of the limpet, and in the "notch" in the shelly lip of a large number of whorled shells, like the whelk, conch, etc. Throngh these loles, when the animal is 
expanded, are protruded tiny waving feelers that warn him of the approach of any danger in time to withdraw underneath his shield.

To the Indians of California the haliotis was very valuable. They wore it as an ornament about their necks and in their hair. The tribes of the interior were so attracted by its glitter that they were willing to pay a large price in barter to possess it. A horse was not an infrequent exchange for a fine specimen. I have seen these shells, rudely polished, dangling in the braids of Indian braves, and around the necks of vainglorious squaws of every tribe from New Mexico northward to the far upper Missouri plains. Recent explorations in the prehistoric mounds of the Ohio Valley show that this shell was possessed by many families of the builders who buried them in the graves of friends; yet it is not at all strange that they shonld have travelled so far, when we recall the systematically conducted trading carried on among the red men, and the distances some of their traders are known to have wandered.

By stopping the holes, this dish-shaped shell became useful as a receptacle. Where it was common it served in this way all sorts of household purposes; but in the interior it was devoted chiefly to the more select purpose of preserving paint-earths and valuable trinkets. The heavier ones were sometiines broken in such a way as to be mounted upon handles, hatchet-wise, and, in the shape of cleavers or bludgeons, became formidable weapons in the hands of savage warriors.

The chief utility of the abalone, however, was as the principal material out of which the natives of the sonthern part of California fabricated their ornament-coins which served as money, and the making of which is described in an ensuing chapter. 


\section{XXI.}

\section{THE SHELL-MONEY OF THE NATIVE AMERICANS.}

$r$ HE use of a circulating medium to facilitate commerce by simplifying the awkward devices of barter is supposed to indicate a considerable advance towards civilization in the people employing it. On this score the North American Indians onght to stand high in the list of barbarians, since they possessed an aboriginal money of recognized value, although it had no sanction other than common custom. This money was made from sea-shells, and was known by varions names, of which one-wampum-has survived popularly, though in a somewhat changed shape; for while it originally meant a particular kind, it is now used as an American word to designate all varieties of shell beads and money.

Sea-shells, indeed, seein to have commended themselves for this purpose to widely different peoples. The great circulation which the cowryshell (Cypraea moneta) attained in tropical Africa, India, and the South Sea islands, will occur to the reader. It was once the coin of those regions to the exclusion of everything else in trading with the savages, and ships going after cargoes of ivory, palm-oil, sandal-wood and similar products, were obliged first to provide themselves with cargoes of cowries at Zanzibar or some other port where they could be bought. This small shell, smooth, shining, easily perforated, not too common, was the most suitable thing for the purpose that could have been found. It conld not be produced artificially, or counterfeited, or acquired withont considerable exertion. It therefore represented an expenditure of labor on the part of its possessor, and became at once a purchasing power. No alterations were made to the Cyprcea, except to punch a small hole in it when it was desired to put a thread throngh; and in this respect the Dentalium, which, as we shall see, served as money among the Indians of the Oregon coast, resembled it - that shell being easily strung, and therefore used whole.

The importance of the cowry (Cyproa moneta) is shown by the statistics of commerce during the present century. In 1843 it was recorded 
that this shell was the current coin of Bengal, but it required 3200 to equal a rupee-abont fifty cents. Between 1850 and 1855 more than a thousand cwt. on the average were imported into Liverpool, to be used in the African trade, these coming from the Mediterranean and Indian Seas. Some portions of Africa, again, export cowries to India. To get them at Zanzibar several ships go annually from Hamburg, and having loaded, proceed to the west coast of Africa for the purchase of palm-oil or other produce. In 1870 over $50,000 \mathrm{cwt}$. were imported into Sagos alone, under a duty of one shilling per cwt. This import is diminishing. "Their relative currency varies in different localities. In British India about 4000 pass for a shilling, and the erection of a church, which cost $£ 4000$, is said to have been paid for entirely with cowries. The ordinary gradation or valne on the west coast of Africa is as follows:
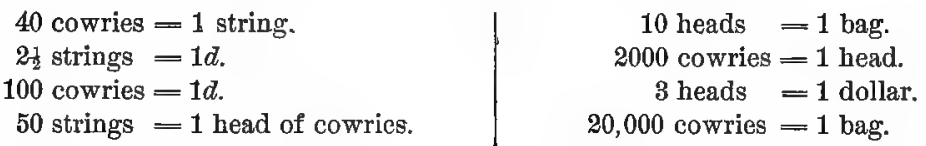

"In other places they are valued at about 1s. $3 \%$. the 1000 . Sometimes 60,000 to 100,000 . (or from $£ 315 s$. to $£ 710 s$.) are given for a young wife, while a more common or ordinary wife may be had for 20,000 cowries or 25s. In Soudan, much as the people trade, they have no other currency than the cowry, of which 2000 shells, weighing from five to seven pounds, are worth only one dollar. Since the recent expansion of traftic in that country the cowry currency has already become an intolerable burden. . . . Although completely depreciated in the territory of the Upper Nile, cowries still form among the Miltoo tribes, between $5^{\circ}$ and $6^{\circ}$ North latitude, a favorite ornament.

"Cowry shells are also... in circulation as money in the Hyderabad State, and in other parts of India.

"The valuable cargoes of sandal-wood obtained in some of the Pacific Islands for the China market are, in the first instance, purchased from the New Hebrides by means of a shell-the Ovulum angulosum, a white porcelainous variety of cowry with a violet-colored lip-which is found in the Friendly Islands but never in the sandal-wood regions. This shell is so highly esteemed as an ornament by the natives of the New Hebrides that for one shell they will give in exchange a ton of sandalwood. The trading captains go expressly to the Tongan Archipelago for the shells, where they sell at a Spanish dollar each."

A recent traveller who visited the Solomon Islands (The Field, April 
$22,1882, \dot{p} .524)$ says that in that group the regular currency consists of native beads, red and white, called makira (Makira being a large bay and district at San Christoval), and malayta money, the latter a kind much smaller than the former. Makira money is not unlike the segment of the backbone of a small fish, and is made from small shells ground to proper size and smothness; the making of this, a slow process, is the employment of the women, who, after its mannfacture, string it together by the liole which exists in the centre. For small change they nse the teetl of the dog and the flying-fox (Pteropus), two of the former and four of the latter equalling one makira.

This approaches nearer than does the cowry currency to the character of the American shell-money of the eastern coast; for, whereas all that was required to turn a cowly into a coin was to find it and punch a sunall hole in it, both makira and wampum were a distinct advance npon this, since they were manufactured articles. In addition to the exertion of securing the mollusk's shell, there was a large expenditure of labor in fashioning the bead which acted as a coin. Lindstrom, a Swedish engineer, says (in Smith's "History of New Jersey") that an Indian's utmost manufacture amounted only to a few pence a day; and all writers enlarge upon the great labor and patience needed to make it, especially at the South. Hence the purchasing power of a wampum bead was far in advance of that of a cowry, a dentalinm of the Pacific coast, or any other unwrought shell used as money.

The origin of American shell-money may be taken to have been somewhat as follows: Shells, by their pretty shape and bright colors, attracted the eye of the savage, who, tinding them easy to suspend about his clothing, employed them as ornaments. Only those tribes living on the shores of the ocean could obtain these shells; but finding them coveted by natives of the interior, exchanges woild quickly spring up. Roger Williams says distinctly that among the trades pursued by different members of the Narraganset tribe, those along the coast "made money" as a regular and profitable occupation. The"longer this continued, and the more frequently it occurred, the nearer the shells came to being money as well as ornaments. In Iroquois myths Iiawatha introduced the use of wampum by stringing small white shells which he found on the shores of one of the northern lakes; but this was for ceremonial purposes, not as money (Hale, "Iroquois Book of Rites," p. 23). Small fresh-water shells, suitable for stringing and unfitted to ornamental purposes, are found plentifully in mounds and graves in the Mississippi Valley, and many archæologists believe that these were employed as the currency of 
the tribes of that region; it is very probable, but there seems to be little or no positive evidence otherwise that such was the case. Perforated pearls also occur in great quantities, and probably answered a similar purpose to beads in the Sonth and West.

That the bead-money was an evolntion directly from the use of single separate shells seems evident from these and various other considerations and matters of evidence. The only opposing circumstance is the statement of the missionary, Loskiel, who asserts that the natives of sonthern New Jersey "used to make their strings of wompom chiefly of small pieces of wood of equal size, stained either black or white. Few were made of muscles, which were esteemed very valuable and difficnlt to make; for, not having proper tools, they spent much time in finishing them, and yet their work had a clumsy appearance." This is the only hint of such a custom I have ever seen; and no such thing is mentioned by Lindstrom, who surveyed New Jersey (where Loskiel wrote) as early as 1640, or in Smith's history of that State, written long previous to Loskiel's account. If the latter was right, his words probably applied to the belts of wampumbeads by the aid of which messages were carried and ceremonials conducted among all the eastern Indians - an interesting phase of the subject outside of my present inquiry.

However the custom began, the very earliest accounts of North America show that this money was in cornmon and widespread service among the natives as far north as the Saskatchewan, and westward to the Rocky Mountains. Among the far western tribes, who obtained it after a succes-. sion of barterings throngh races living between them and the coast, the beads came to be considered rare and precions, and were devoted almost wholly to ornament; but everywhere east of the Mississippi their prehistoric circulation, commonly, as a buying and selling medium, seems well assured. The evidences of this are derived not only from the accounts of early visitors to the tribes of the interior, but from relics abounding at their village sites and in their graves. The Pacific coast had a shell-money of entirely different character from that of the Atlantic side of the continent, but I defer reference to it until later, further than to say that in the interior of the continent it divided the honors of trade with the eastern beads.

The shell-money of the eastern coast of the United States, then, consisted of elongated beads of two kinds and values, represented by different colors. One kind was white, the other purplish or brownish black.*

* Later a blue kind was added, but this was an innovation of white traders. 
A great variety of names for one or the other or both of these beads appears in the books of the early voyagers and historians, and it is very difficult for us now to come at the true significance of the terms in most cases.

Northward of New York seawan was the usual name applied, and it seems to have been used generically for all sorts. of shell-money. Similarly "wampum" (which Loskiel spells wompom, and defines as an Iroquois word "meaning a muscle"), in its numberless spellings and derivatives, came to be used generically, and thus has descended to our popular vocabulary. But this has occurred, apparently, through defiance of its proper restriction; for as well as I can make out, the word originally, and etymologically, belonged only to the white beads.

The white variety was most plentiful and of inferior value. It was commonly made from the large univalves, Sycotypus canaliculatus and Fulyur carica, whose pear-shaped, coiled shells I have described in a previous chapter. Yet sometimes other material was. used. Thus the "New England's Rarities Discovered," by John Josselyn, gent., reads: "A kind of cocele, of whose shell the Indians make their. beads called wampumpeage* and mohaicks. The first are white," etc. This is an exception, or an error. Roger Williams wrote in his "Key :" "The New England Indians are ignorant of Europe's coyne. . . Their owne is of two sorts; one white, which they make of the stem or stock of the Periwincle, which they call Meteaûhok, when all the shell is broken off." Again he says: "Theil white they call Wampam (which signifies white)." The wampum made from the periwinkle was distinguished in law as late as 1663 in Rhode Island; and in 1679 Wooley, describing New York, says of it: "They [the Indians] make their White Wampum or Silver of a kind of Horn, which is beyond Oyster-bay"-a phrase that certainly would not apply to a bivalve.

It appears certain, then, that the coiled, univalve, "periwinkle" shells were largely used for this inferior grade of currency. It was only necessary to take out one or two small sections. of the central column of the spire and smooth the edges; the hollow core made them natural beads.

Sinith's "History of New Jersey" informs us that this was precisely the plan followed, for it relates that "the white wampum was worked ont of the inside of the great conques into the form of a bead, and perforated to string on leather." Still earlier testimony comes from the southern coast. Thus Beverly, in his "History and Present State of

* Wampampeege.-W W INTHRoP (1634). 
Virginia" (1705), records that the riches of the Indians there consisted of "Peak, Roenoke, and such-like trifles made out of the Cunk Shell. Peak is of two sorts, or rather of two colors; both are made of one Shell, tho' of different parts; one is a dark Purple Cylinder, and the other a white; they are both made in size and figure alike." The same author also mentions a poorer kind of money yet, "made of the cockle shell, broke into small bits with rough edges, drill'd through in the same manner as Beads, and this they call Roenoke." Other authorities corroborate this, and prove what I have been led to enlarge upon-the fact that the conchs were used mainly as material for the white beads-becanse the popnlar idea has been that all the shell-money was made from the valves of quahaug.

Out of the quahang was fabricated that dark-colored variety of wampum-the "gold" of the red men. This bivalve is one of the commonest mollusks on the shore of eastern America south of Cape Cod. It is a thick, somewhat globose shell, which buries itself in the sand under pretty deep salt-water. The Indians gathered it alive by wading and feeling with the toes, or by diving, and ate the animal with great gusto; it remains, indeed, an article of extensive sale in all our markets, nnder the name of "round" or "hard" clam, or "quahaug"-the scientific name of which is Venus mercenaria.

In regard to the word "qualuang," Mr. J. H. Trumbull, of Hartford; Connecticut, who leads students in the etymology of the languages of the native races of New England, writes me as follows: "For the spelling and derivation of the common name Quahang, in the last edition of Webster, I am, I believe, responsible. The pronunciation there given is that of eastern Connecticut and Rhode Island-kwaw'hogg. I have occasionally heard the name reduced to a monosyllable-quaw'g; and farther east it is often made pooquaw'. In a note to my edition of Roger Williams's Indian Key ("Narraganset Club Publications," vol. i., p. 140) I gave two or three other dialectic forms of the Indian name. As you may not have the volume within reach, I copy the note: Pequot, $p^{\prime}$ quaughhaug.* Gus. Stiles, MS.-Abnaki, pekwe, pl. pełwahak, 'huitres'-Râle. The signification appears to be, either 'thick shell' or 'tightly-closed shell.' The Delaware equivalent is, as Zeisberger wrote it, 'pooque-u, a mnscle.' I have now no doubt that the second meaning given above (tightly-closed)

* "A piece of Poquahauges, a rare shell, and a dainty food with the Indians. The flesh eats like veal: the English make pyes thereof; and of the shells the Indians make money."-Winthrop (1634). A historical pamphlet gives Poquau as the name used in Martha's Vineyard in 180\%. - E. I. 
is the true one, distinguishing the Tenus mercenaria from the more common Mya, or gaping clam. Strachey's Virginia vocabulary (abont 1612) gives cawaih for 'oysters,' which is, I have no doubt, another' form of the same name $=p^{\prime}$ cawaih. The vocabularies mentioned are the only ones I now remember in which the name is found."

Towards the anterior end of the otherwise white interior of each of the valves of this mollusk's shell is a deep purple or brownish-black scar, indicating the point of muscular attachment-fishermen call it the "eye." This dark spot was broken out of the shell by the Indians, and formed the material of their more valuable coins. In descriptions of it we meet with a new list of terms and additional confusion. It was worth, on the averuge, twice as much as the white variety, and the latter was frequently dyed to counterfeit it.

In New England Roger Williams describes this superior money as follows: "The second is black, inclining to blue, which is made of the shell of a fish which some English call Hens, Poquaûhock." This money, he says, was called "Suckáubock* (Śucki signifying blacke)." Josselyn gives mohaicks as the Connecticut word. Among the Dutch on the Hudson River (and frequently elsewhere) seawan was the usual tern-and they spoke of it as black or white-the various shades of blue, purple, and dull black receiving separate names, but regarded as of equal value. In notices of it among the early writers, whose carelessness is apparent, the words wampum, wompam, wompom, wampampeege, wampumpeage, wampeage, peage, peag, wampum peak, mohaicks, suckauhock, seawan, seawant, roenoke, ronoak, and other's occur. Seawant appears to have been properly a generic term indicating any and all kinds of shell-money; wampum was often used thus, and now is so used altogether; but originally it seems to have meant the white beads alone, while the words peag (in its various forms), suckauhock and mohaicks represented the black. In Beverly's "Virginia," however, this is precisely reversed, which leads us to believe that the author made a mistake. Southern writers unite in making peak generic, while roenoket is a word unknown at the North. All of these terms are misspelled derivatives from roots meaning "shell," and the Indian names for Venus mercenaria show their close affinity with the group. Porcelan was a Dutch appellation, heard only among the traders at New York.

* Misprint for suckauhock.

$\uparrow$ " Roanole (a small kind of beades) made of oyster shells, which they use and pass one to another, as we doe money (a cubites length valuing six pence)."-HarIot (1614), p. 41. For "a bushel" of these Powhatan sold his daughter. 
Some of the methods of making this finer sort of bead-coin are interesting. "Before ever they had awle-blades from Europe they made shift to bore their shell-money with stone." This was around Narraganset; and in the shell-heaps along the New England coast are hidden these old flint awls of prehistoric design, which may have been revolved in some cases by a small bow such as jewellers employ at present. In Virginia, Beverly found that both sorts of peak were "in size and figure alike, and resembling the English Buglas, but not so transparent nor so brittle. They are wrought as smooth as glass, being one-third of an inch long and about a quarter in diameter, strung by a hole drilled through the centre." Lawson describes the drilling, "which the Indians manage with a nail stuck in a cane or reed. Thus they roll it continually on their thighs with their right hand, holding the bit of shell with their left; so in time they drill a hole quite through it, which is very tedious work, but especially in making their ronoak."

The coinage, so to speak, of this shell-money was, therefore, a work of patient labor, and great delicacy of manipulation, and there was no fear of increasing the supply beyond the demands of trade by the worth of one deer-skin, since a savage would rarely make a single bead more than sufficed for his immediate necessities. It was a true medium of exchange -real currency. All the early accounts speak of it as "riches" and "money" and "current specie."

The Delawares in fact had a tribal treasury of wampum, out of which were paid the expenses of public affairs. At certain feasts a great quantity of it was scattered, to be scrambled for by the youngsterscarnival fashion. Hired servants at these feasts or anywhere else were paid in wampum, and great quantities were thrown into graves.

It followed as a matter of course that the shrewd first traders who came to New York and New Jersey should adopt this currency which all the natives were accustomed to, receiving it as pay for their merchandise, and with it buying peltries of the Indians. Thus wampum quickly became a standard of values, the currency of the colonists to a great extent in their transactions with each other, and even a legal tender.

Though the beads were often used separately, the ordinary and approved manner was to string them upon the sinews of animals or upon cords, which might or might not be woven into plaits about as broad as the hand, called wampum belts. The length of these strings varied, but in the North about six feet was found the usual quantity computed by 
the Indians, and hence the fathom became the unit of trade.* In the Carolinas, according to Lawson, the strings were measured in cubits, "as much in leugth as will reach from the elbow to the little finger."

The Indians themselves were particular as to quality and size of the beads, for upon the elegance of their finish (to speak scientifically, the amount of labor and tine they represented) depended their value. "When these beads are worn out," says Lindstrom, "so' that they cannot be strung neatly and evenly on the thread, they no longer consider them as good. Their way of trying them is to rub the whole threadful on their noses; if they find it full and even, like glass beads, then they are considered good, otherwise they break and throw them away. Their manner of measuring their strings is by the length of their thumbs: from the end of the nail to the first joint makes six beads." This was in New Jersey.

Seeing that profit and wealth lay in the possession of wampum, the burghers along the Hudson River, as the easiest way of getting rich, began to make it. With their tools of steel this could be done very rapidly; but with absence of the painstaking care with which the Indian wronght came a loss of value. To widen their market it was carried to New England. Considering the many references to it, and the nndoubted fact that it was made there aboriginally as well as southward, I an at a loss to understand Gowan's statement that " the use of wampun was not known in New England until it was introduced there in October, 1627, by Isaac de Razier, who was acting as a sort of amity-treaty commissioner from the New Netherlands to Plymouth Colony. He carried wampum thither and bought corn. To this introduction the pious Hubbard attribntes all the wars which ensued between the Puritans and the Indians. "Whatever were the honey in the month of that beast of trade, there was a deadly sting in the tail," he wails out. "For it is said they (the Dutch) first brought our people to the knowledge of wampam-peag; and the acquaintance therewith occasioned the Indians of these parts to. learn the skill to make it, by which, as by the exchange of money, they purchased store of artillery, both from the English, Dutch, and French, which proved a fatal business to those that were concerned in it. It seems the trade thereof was at first, by strict proclamation, prohibited by

* "They fashion both sorts like beads, and String them into several lengths, but the most usual measure is a Fathom; for when they make any considerable bargain, they usually say so many Fathom. So many Black or so many white Wampams make a farthing, a penny, and so on : which Wampam or Indian Money we valued above the Spanish or English Silver in any Payments, because of trading with the Indians in their own coin."-Wooley's Nero York, 1679. 
the king. Sed quid non mortalis pectora cogis, duri sacri fames! The love of money is the root of all evil, \&c."

The anthority for Gowan's statement is probably an intimation in Nathaniel Morton's "New England's Memoriall" (1669), p. 67, followed by the remark that "sundry unworthy persons" sold firearms to the Indians for it.

I am not singular in donbting the accuracy of this tradition, for in addition to the contradictory evidence already quoted, I observe that, in his work on the "Antiquities of the Southern Indians," C. C. Jones remarks: "It inay be safely asserted that this shell-money was manufactured along the Atlantic coast, from Maine to Florida, and on the Gulf coast, certainly as far sonth as Central America." The natives of Rhode Island certainly practised the art before the arrival of Europeans.

Whatever may be the truth on this point, it is a fact that at a very early day both Dutch and English merchants adopted it as the most profitable medium with which to do business. The red men, finding a new valne placed upon their ancient wealth, applied themselves anew to the industry, and wampum increased rapidly in amount, but with the usnal result of depreciation in value. Political economy applies as well to wampum as to silver and gold. Indeed the "precious" metals were of little account then. "An Indian chief to whom the value of a rix-dollar was explained by the first clergyman of Rensselaerwyck, langhed exceedingly to think the Dutch should set so high a value upon a piece of iron." Mr. Gowan has very clearly explained how trade was helped by the wampum at the first, and I quote his paragraph:

"Althongh the general distinction of this seawant was black and white, yet that in use in New England was black, blne, and white, and that of the Five Nations of Indians was of a purple color. . . . The process of trade was this: The Dutch and English sold for seawant to the Indians of the interior their knives, combs, scissors, needles, awls, lookingglasses, hatchets, guus, black cloth, and other articles of aboriginal traffic (the Indians at this time [about 1665 ] rejected fabrics in which the least white color in their texture was discoverable); and with the seawant bought the furs, corn, and venison from the Indians on the seaboard, who also, with their shell-money, bought such articles from the aborigines residing farther inland; and by this course the white men saved the trouble of transporting their furs and grain throngh the country. Thus, by this circulating medium, a brisk commerce was carried on, not only between the white people and the Indians, but also between different tribes among the latter. So much was this seawant the circulating unediun of many of 
the European colonies in North America, that the different governments fonnd it necessary to make regulations on the subject."

It was during the administration of Willian Kieft that wanpum currency became of this importance in New York. Washington Irving, in his "Knickerbocker" History, Chapter VI., gives a humorous account of it, and the troubles to which it gave rise. Kieft began by endeavoring to flood the colony with this Indian money, which, as I have slıwn, the Indians were content to take in exchange for their peltries, but which of course had no intrinsic value. Says the veritable Diedrich, than whom we could wish no better anthority:

"He began by paying all the servants of the Company and all the debts of the government in strings of wampum. He sent emissaries to sweep the shores of Long Island, which was the Ophil of this modern Solomon, and abounded in shell-fisl. These were transported in loads to New Amsterdam, coined into Indian money, and lannched into circulation.

"And now for a time affairs went on swimmingly.... Yankee traders poured into the province, buying everything they conld lay their hands on, and paying the worthy Dutchmen their own price-in Indian money. If the latter, however, attenpted to pay the Yankees in the same coin for their tinware and wooden bowls the case was altered; nothing would do bnt Dutch guilders and such-like 'metallic currency.' What was worse, the Yankees introduced an inferior kind of wampum made of oyster-shells, with which they deluged the province, carrying off in exchange all the silver and gold, the Dutch herrings and Dutch cheeses. Thus early did the knowing men of the East manifest their skill in bargaining the New Amsterdamers out of the oyster and leaving them the shell.

"It was a long time before William the Testy was made sensible how completely his grand project of finance was turued against him by his Eastern neighbors; nor would he probably have ever found it ont had not tidings been brought him that the Yankees had made a descent upon Long Island, and had established a kind of mint at Oyster Bay, where they were coining up all the oyster banks.

"Now this was making a vital attack upon the province in a double sense, financial and gastronomical. Ever since the council dinner of Oloffe the Dreamer, at the founding of New Amsterdam, at which banquet the oysters figured so conspicuously, this divine shell-fish had been held in a kind of superstitious reverence at the Manhattoes-as witness the temples erected to its cult in every street and lane and alley. In fact it is the standard luxury of the place, as is the terrapin at Philadelphia, the soft crab at Baltimore, or the can vas-back at Washington. 
"The seizure of Oyster Bay, therefore, was an outrage not merely on the pockets, but the larders of the New Amsterdamers; the whole community was aroused, and an oyster crusade was immediately set on foot against the Yankees. Erery stout trencherman hastened to the standard; nay, some of the most corpulent Burgomasters and Schepens joined the expedition as a corps de reserve, only to be called into action when the sacking commenced."

A valiant army under Stoffel Brinkerhoff having marched to Oyster Bay, ronted the English there, "and would have driven the inhabitants into the sea if they had not managed to escape across the sound to the main-land by the Devil's Stepping-stones, which remain to this day monnments of this great Dutch victory over the Yankees." This done-

"Stoffel Brinkerhoff made great spoil of oysters and clams, coined and uncoined, and then set out on his return to the Manhattoes. A grand triumph, after the manner of the ancients, was prepared for him by William the Testy. He entered New Amsterdam as a conqueror, mounted on a Narraganset pacer. Five dried codfisl on poles, standards taken from the enemy, were borne before him, and an immense store of oyster's and clams, Weathersfield onions, and Yankee 'notions' formed the spolia opima; while several coiners of oyster-shells were led captive to grace the hero's trinmph.

"The procession was accompanied by a full band of boys and negroes, performing on the popular instruments of rattle-bones and clam-shells, while Antony Van Corlear sounded his trumpet from the ramparts.

"A great banquet was served in the Stadthouse from the clams and oysters taken from the enemy, while the governor sent the shells privately to the mint, and had them coined into Indian money with which he paid his troops."

To check the evil effects of this "inflation," a law was passed at the instance of Governor Kieft by the Council of the New Netherlands, on April 18, 1641, which reads thus :

"Whereas very bad Wampum is at present circulating here, and payment is made in nothing but rough, unpolished stuff which is brought lither from other places, where it is fifty per cent. cheaper than it is paid out here, and the good, polished Wampum, commonly called Manhattan Wampum, is wholly put out of sight or exported, which tends to the express ruin and destruction of this Conntry; In order to provide in time therefor, We do, therefore, for the public good, interdict and forbid all persons... to receive in payment, or to pay out, any unpolished Wampum 
during the next month of May, except at Five for one Stiver, and that strung, and then after that Six beads for one Stiver. Whosoever shall be found to have acted contrary hereunto, shall provisionally forfeit the Wampum which is paid out and ten guilders for the Poor, and both payer and payee are alike liable. The well-polished Wampum shall remain at its price as before, to wit, Four for one stiver, provided it be strung."

In November, 1647, another act was passed, allowing loose wampum to circulate, as it was needed for change, but excluding imperfect and unpierced specimens. These measures of the. Dutch government were at once imitated in the Connecticut legislature by a re-enactment of some precautionary laws on this subject previously in force for many years, by which it was ordered, "That no peage (as they call seawant), white or black, bee paid or leceived, but what is strunge, and in some measure strunge sntably, and not small and great, uncomely and disorderly mixt, as formerly it hath beene."

In Massachusetts "wamparn-peag". was legal tender" (Act of 1648) for" all debts less than forty shillings, "except county rates to the treasurer," the white at eight for a penny, and the black at four for a penny. The Pequot Indians, in the year 1656, paid as a tribnte to the United Colonies of New England 215 fathouns of wampum - of which amount the Commissioners of the United Colonies paid to Thomas Stanton, their agent among the Indians, 120 fathoms for his salary. Having deducted this, there remained 95 fathoms, which, together with 51 fathoms at $\mathrm{New}$ Haven, in all 145 fathoms, was divided among the United Colonies, according to the number of males enumerated in the year 1665, in the following manner:

To Massachusetts.......94 fathoms, 2s. $6 d_{. .} \mid$To Connecticut........20 fathoms, 2s. $0 d$. To Plymouth.........18 " 0s.9d. To New Haven........13 “ 0s.6d.

This was the first distribution of public money in the good old time of our history.

It was not until 1661 that shell-beads were declared no longer legal tender; but long subsequent, wampum served as money in New England, as it did everywhere else.*

* "In a Manuscript record of the province [of New Netherlands], dated 1659, Library of the Historical Society, is the following mention of Indian money:

" 'Seawant, alias wampum-Beads manufactured from the Quahaug or will.. A shellfsh formerly abounding on our coasts, but lately of. more rare occurrence, of two colors, black and white; the former twice the value of the latter. Six beads of the white and 
It would be impossible to get at the volume in circulation, but values are accessible. These remained substantially those I have mentioned* until 1673 , when the true wampum had become very scarce, owing to the hoarding of it by the Indians and its disposal to remote tribes. The Dutch council, therefore, issued an edict enhancing its legal value twentyfive per cent, and permitting the Swedes of southern New Jersey, who had been plundered by Dutch privateers, to lay an imposition in wampum to the value of four guilders upon each anker of strong rum, and so on.

Such an action as this increase of value one-fourth, by act of council, the red men could not in the least comprehend. Adair says they had a fixed value for every bead, and "bought and sold at the current rate, without the least variation for circumstances either of time or place; and now they will hear nothing patiently of loss or gain, or allow us to heighten the price of our goods, be our reasons ever so strong." This was a sad case for an Indiun trader!

Nearly a century $†$ passed, and still the shell-money held a firm place in colonial trade all along the coast. That observant traveller, Dr. Kalm, who visited and wrote about the American settlements in 1748, saw this money. in constant nse at that period all through the coast towns. "A traveller," he says, "who goes to trade with the Indians, and is well stocked with wampum, may become a considerable gainer; but if he take gold coin or bullion, he will undonbtedly be a loser; for the Indians who live

three of the black for an English penny. The seawant depreciates from time to time. The New England people make use of it as a means of barter, not only to carry away the best cargoes which we send thither, but to accumulate a large quantity of beavers and other furs; by which the company is defrauded of her revenues, and the merchants disappointed in making returns with that speed which they might wish to meet their engagements : while their commissioners and the inhabitants remain overstocked with seawant-a sort of currency of no value except with the New Netherland savages," "etc.

* In New Jersey, 1640. Six beads valued at two stivers for black and one stiver for white.

In New York, 1641. Polished good "Manhattan" wampum, four beads for one stiver; five and six unpolished beads for one stiver.

At Boston, 1648. White, eight beads for one penny ; black, four for one penny.

New York, 1659-see preceding foot-note.

In Rhode Island, 1663. White (periwinkle), six beads for one penny ; black (quahaug), three beads one penny; by the fathom, three hundred and sixty white beads, five shillings sterling; a fathom black, ten shillings sterling.

$\uparrow$ New Jersey, 1765. "Every bead is of a known value, and a belt of a less number is made to equal one of a greater, by so many as is wanting fastened to the belt by a string. . . Eight white wampums, or four black, passed at this time as a stiver ; twenty stivers made what they called a guilder, which was about aixpence of present currency." Sмrтн, History of Nero Jersey. 
farther up the country put little or no value upon these metals which we reckon so precious, as I have freqnently observed in the conrse of my travels. The Indians formerly made their own wampums, though not withont a deal of trouble; but at present the Europeans employ themselves that way, especially the inhavitants of Albany, who get a considerable profit by it." This last fact is also mentioned by the Reverend Burnaby, who further saw it made by white men on Staten Island.

Only a little later (1756) Jacob Spicer, the most prominent man in Cape May County, New Jersey, advertised to barter goods "for all kinds of produce and commodities, and particularly for wampum," offering five dollars reward to the person making the largest amount of it. "He succeeded in procuring a quantity of the wampum, and before sending it off to Albany [cf. antèa] and a market, weighed a shot-bag full of silver coin and the same shot-bag full of wampum, and found the latter most valuable by ten per cent."

It was not, however, in the Northern States alone that wampum cirealated as money. Old historians of the Sonthern Colonies make nuany references to it. 'I have already, in another connection, quoted some sentences from Beverly's "History and Present State of Virginia," but repeat them here in order to give the entire passage its full significance. He says:

"The Indians had nothing which they reckoned Riches before the English went anong them, except Peak, Roenoke and such like trifles made out of the Cunk Shell. These past with them instead of Gold and Silver, and serv'd them both for Money and Ornament.

"Peak is of two sorts, or rather of two colours; both are made of one Shell, tho' of different parts; one is a dark Purple Cylinder, and the other a white; they are both made in size and figure alike, and commonly much resembling the English Buglas, but not so transparent nor so. brittle. They are wronght as smooth as Glass, being one third of an inch long, and about a quarter diameter, strung by a hole drilled thro? the center. The dark color is the dearest, and distinguish'd by the name of Wampom Peak. The English men that are call'd Indian Traders value the Wampom Peak at eighteen pence per Yard, and the white Peak at nine pence. The Indians also make Pipes of this, two or three inches long, and thicker than ordinary, which are much more valuable. They also make Runtees of the same Shell, and grind them as smooth as Peak. These are either large, like an Oval Bead, and drill'd the length of the Oval, or else they are circular and flat, almost an inch over, and one-third of an inch thick, and drill'd edgeways. Of this Shell they also make round Tablets of about four inches diameter, which they polish as smooth 
as the other, and sometimes they etch or grave thereon Circles, Stars, and a Half-Moon, or any other figure suitable to their fancy. These they wear instead of Medals before or behind their Neck, and use the Peak, Runtees, and Pipes for Coronets, Bracelets, Belts or long Strings, hanging down before the Breast, or else they lace their Garments with them, and adorn their Tomahawks and every other thing that they value.

"They have also another sort which is as current among them, but of far less value; and this is made of the Cockle shell, broke into small bits with rough edges, drill'd through in the same manner as Beads, and this they call Roenoke, and use it as the Peak.

"These sorts of Money have their rates set upon them as unalterable, and current as the values of our Money are."

The "Westover Papers" say of the conch: "The extremities of these shells are blue, the rest being white, so that Peak of both these colours are drilled out of the same shell, serving the natives [of the Virginia coast] both for ornament and money, and are esteemed by them beyond gold and silver."

"The money of the Carolina Indians," says Lawson ("History of Carolina"--Raleigh reprint, 1860, p. 315), "is of different sorts, but all made of shells which are found on the coast of Carolina, which are very large and hard so that they are very difficult to cut. Some English smiths have tried to drill this sort of shell-money, and thereby thought to get an advantage, but it proved so hard that nothing conld be gained." Lawson then describes the valuable shell "gorges, which they wear about their neck in a string," and which seem also to have served as coin in certain cases; "bnt," he adds, "the general and current species of all the Indians in Carolina, and, I believe, all over the continent as far as the Bay of Mexico, is that which we call Peak and Ronoak; but Peak more especially." He says that peak is the same as the New York wampum or porcelan, that five cubits of it will purchase a dressed doe-skin, and seven or eight a dressed buck-skin. He continues:

"An Englishman could not afford to make so much of this wampum for five or ten times the value; for it is made out of a vast, great shell, of which that country affords plenty; where it is ground sinaller than the small end of a tobacco-pipe or a large wheat straw. Four or five of these make an inch, and every one is to be drilled through, and made as smooth as glass, and so strung as beads are; and a cubit of the Indian measure contains as much in length as will reach from the elbow to the end of the little finger. They never stand to question whether it is a tall man or a short man that measures it; but if this wampnm peak be black 
or purple, as some part of that shell is, then it is twice the value. This the Indians grind on stones and other things till they make it current; but the drilling is the most difficult to the Englishman, which the Indians manage with a nail stuck in a cane or reed. Thus they roll it continually on their thighs with their right hand, holding the bit of shell with their left; so, in time, they drill a hole quite through it, which is a very tedions work-but especially in making their ronoak, four of which will scarce make one length of wampum. The Indians are a people that never value their time, so that they can afford to make them, and never need to fear' the English will take the trade ont of their hands. This is the money with which you may buy skins, fnrs, slaves, or anything the Indians have; it being the mammon (as our money is to us) that entices and persuades them to do anything, and part with everything they possess except their children for slaves. As for their wives, they are often sold and their daughters violated for it. With this they bny off murder's; and whatsoever a man can do that is ill, this wampum will quit him of, and make him, in their opinion, good and virtuous, though never so black before."* "When Cabeza de Vaca," says Jones, "set out upon his trading expedition, he carried with him from the Gulf coast cones and other pieces of sea-snail, conches used for cutting, and 'sea-beads.' These he traded away to the Indians inhabiting the interior. . . . On various occasions shell-beads were offered as presents by the Sonthern Indians to the Spaniards. ... A mong the articles regarded as ' great riches' by the inhabitants of Pacaha, Bedma enumerates 'beads made of sea-snails."

Let us now transfer our inquiries to the western half of the continent.

Though with the tribes of the central region of North America commercial transactions were all a matter of barter, and the standard of value (if any existed) varied with the especial local commodity, like buffalorobes on the plains, blankets among the Navajoes and Puebloans, or otterskins in.Alaska, yet the coast tribes of the Pacific had a true money when white men first became acquainted with them.

This currency seems to have been confined nearly or quite within the present boundaries of the United States and British Columbia, and it comprised a variety of forms, one of which in the northern and another sort in the southern part of this area, approached in solid and widely recognized value the substantial wampum of the East.

The northern and most celebrated of these varieties was the hiqua,

* Compare Dr. Brickell's "Natural History of North Carolina" (1737), p. 337, et seq. 
hikwa, hiaqua, or ioqua-for all tliese (and other) forms of the Chinook jargon word are found. Hiqua consisted of strings of the shell of a mollusk (Dentalium) called by conchologists " tusk-shells." These were gathered off the shores of Vanconver's and Queen Charlotte's Islands by prodding into the sea-bottom a long pole with a spiked board* at the end, upon the points of which the slender shells were caught. None were quite two inches in length, many much smaller; and among all the Indians north of the Columbia River the. unit of measurement was a string of about a fathour's length, or as mnch as could be stretched between the extended hands of the owner. The larger the shells the greater their value; forty to the fathorn was the standard, fifty to the fatlom being worth scarcely half so much. Early in the present century a fathom was worth ten beaver-skins in dealing with the whites in Oregon; but with the advent of the Hudson Bay Company's traders the hiqua disappeared to a great extent, and values were reckoved in blankets, as is now the case in many parts of Alaska and Aretic America.

. South of the fur-trading posts, however, this money survived to a much later date, and is even yet to be seen in certain remote districts, a large Enropean Dentalium being exported to Alaska for trading with Indians of the interior. "Those aboriginal peddlers, the Klikitats," and other Columbians, carried it to. sonthern Oregon and to the Klamath region year after year, whence it spread through all northern California, receiving there a new name, allooochick, and an alteration of estimate. The northern measure between the extended finger-tips was discarded on the Klamath River for a string scarcely half that length. Among the Hupas, still farther southward, the standard became a string of five sliells. Nearly every man had ten lines tattooed across the inside of his left arm about half way between the wrist and the elbow; in measuring shellmoney he drew one end over his left thumb-nail, and if the other end reached to the uppermost of the tattoo lines, the five shells (about 1870) were worth $\$ 25$ in gold, or even more. Only one in ten thousand would reach this distinction, so that the ordinary worth of a string was $\$ 10$. "No shell is treated as money at all," says Mr. Powers, "unless it is long. enough to rate as twenty-five cents. Below that ... it goes to form part of a woman's necklace. Real money is ornamented with little sciratches or carvings, and with very narrow strips of thin, fine snake-skin, wrapped

* "Obtained at a considerable depth by means of a long pole stuck in a flat board about fifteen inches square. From this board a number of bone pieces project, which, when pressed down, enter the hollow ends of the shell . . . and [they] are thus brought to the surface."-KANE, Wanderings of an Artist. 
spirally around the shells; and sometimes a tiny tuft of scarlet woodpecker's down is pasted on the base of the shell." These marks manifestly were designed to give the money some sort of sanction-make it represent somewhat the labor put upon the beads with which it had to compete.

For sonth of the Eel River, and thence throughout all central and sonthern California, the staple currency was a shell-money resembling the eastern wampum. Hiqua and allocochick were simply shells of some rarity, ground at the tip sufficiently to admit of being strung, but the hawok and üllo of California were carefully manufactured, and represented a real cost of labor and time, though they had no intrinsic value. These Californian coins were of different shape and valne.

The first-named (hawol) was of least worth, standing in the place of, the white wampum of the East, or our silver. It consisted of circular disks or buttons from a quarter of an inch to a whole inch in diameter, and of the thickness of the shell from which it was cnt. For this purpose a heavy bivalve was chosen-usually the Saxidomus auratus of Gouldand broken into discoidal fragments. These pieces were then ground smooth and polished by rubbing on blocks of sandstone, which often had to be brought from a long distance to the maker's rancheria. This finished, a hole was bored through the centre with a wooden flint-tipped drill, forced to revolve very rapidly by a buckskin string which wonnd upon it, unwound and rewound itself in an opposite direction, through the incessant vertical movement of a loose cross-bar in the operator's hand. These hawok-disks were then strung upon sinews, or on cords made of milk-weed fibre, but the strings were not of invariable length, though beads of like size must be put together. The very best of this was worth twenty-five cents apiece ten years ago; but the smallest always went by the string. This white-bead money was (and to a certain extent still is) the great medium of Indian trading among themselves.

Theil gold, so to speak (the üllo), is made from the shell of the abalone (Haliotis), and chiefly from the red species (H. mufescens). These shells are cut with flints into oblong, key-stone-shaped pieces from one to two inches in length, according to the curvature of the shell, and a third as broad. Two holes are drilled near the narrow end of each piece, and they are thus strung edge to edge. "Ten pieces," wrote Powers, "generally constitute a string, and the larger pieces rate at $\$ 1$ apiece, $\$ 10$ a string; the smaller in proportion, or less if they are not pretty. Being susceptible of a high polish, this money forms a beantiful ornament, and is worn for necklaces on gala-days. But as money it is rather too large and cumbersome, and ... may be considered rather as jewelry." 
A third sort of money, very rarely seen nowadays, was fabricated on the islands off the southern coast and on the adjacent main-land, ocenrring in the mounds of Contra Costa and Alameda counties, mixed with the small flat disks described above. This was called kol-kol, and was made by grinding off the apex of the univalve shell of Olivella biplicata until a cord conld be passed through. It was slightly esteemed.

Farther south all these forms of shell-cutting disappear in their capacity of money-retaining value only as ornaments-so that their use in trade sonth of California belongs under the head of barter. Thus Bancroft notes of the natives of Sonora, "Pearls, turquoises, emeralds, coral, feathers, and gold were in former times part of their property, and held the place of money."

There seems to have been an immense amount of this regular money, hiqua, allocochick, hawok and üllo on the Pacific coast; Powers thinks an average of $\$ 100$ worth to each male Indian would not be too large an estimate for California at the time of its discovery by the Spaniards. This portion equals the value of two grisly bear-skins, or three ponies, or the price of two wives. However, it was not equally distributed, any more than are riches in more civilized neighborhoods-a point for communists to consider.

The shore tribes were the coiners of this money, and jealously guarded their privileges. With it they bought skins, arms, and implements from the dwellers in the Coast Range, where grew animals and materials not to be obtained along the beach. The mountaineers, in turn, disseminated it far in the interior, where finally the beads were prized and worn as ormaments, and ceased to circulate. Moreover, an enormons waste and destruction was always going on (a fact also true of the Atlantic coast), owing to the practice of propitiatory sacrifices, and the wide-spread custom of burying or burning all the wealth with each man (or noted woman) who died. Thus the demand was always greater than the supply, and a high value maintained. It is astonishing to read how shrewd and thrifty the Indians were in respect to this shell coinage. When Americans grew numerous, and began to manufacture large quantities of the hawok, of conrse its value declined; moreover, with the partial civilization of the Indians, a new sentiment crept in, and some strange clanges in primitive social economy followed.

At present the younger English-speaking Indians scarcely use it at all, except in a few dealings with their elders, like wife-buying, or for gambling. A young fellow sometimes procures it as an investment, laying away a few strings of it, for lie knows that he caunot squander it at the 
stores; whereas if he really needs a few dollars of current cash he can always "negotiate" his shells with some old Indian who happens to have gold or greenbacks. Americans speculate in it here and there to advantage, working upon the clinging love the aged savages retain for the wealth of their youth. These old men save all of it they can possibly acquire, and hoard it like veritable misers, only on great occasions letting their women-folk wear any as jewellery. This hoarding is not so much miserly greed, however, as it is a religious notion, since to their minds the shell-money is the only thing worthy to be offered upon the funeral pyre of any famous chief or departed friend, or to be sent along with their own souls into the spirit-world. 



\section{N D E X.}

Abalone (Haliotis), 221-226.

"s shell-jewellery, 224.

Agassiz, Alexander, 78, 79, 88.

". Professor Louis, 78.

Alligator (Alligator mississippiensis) in winter, 65 .

Allocochick. (See. Shell-money.)

Amateurs in natural science, 50.

Ancistrodon contortrix, $91,95$.

“ piscivorus, 91, 94.

Antelopes (Antizocapra americana) in winter, 74.

Antilocapra americana, 74.

Antlers, growth of, 168-172.

Arca plexata, 135.

Architeuthis, 161, 164.

Asterias an'enicola, 124.

"vulgaris, 124.

Astragalinus tristis, 15.

Basilisk, the, 28.

Batrachians, 64.

Bats in winter, 72.

Bearded seal, 188.

Bears in winter, 74.

Bee-marten. (See King-bird.)

Birds and Serpents, 28, 30, 96.

" effect of terror upon, 29, 96.

" in winter, 66,68 .

" mimicking powers of, 22 .

" of a brookside, 39 .

" pugnacity of, 27 .

"vigilance of, 22 .

Blarina brevicanda, 33.

Blind animals, 216.

Blood-quahaug (Arca plexata), 135.

Blue-bird (Sialia sialis), 26.

Bob White, a chat about, 175-181.

Borer, the, 145.

Brook, attractive features of a, 39 .
Butterflies in winter, 61.

Butting a log, 14.

Callinectes hastatus, 147.

Cancer irroratus, 147.

Cariacus macrotis, 74.

" virginianus, 74.

Carolina wren, 22-26, 27.

Caudisona tergemina, 91.

Caves, animal life of, 215.

" at Luray, 203.

“ at Pike's Peak, 216-220.

“ characteristics of, 203-220.

" formation of, in limestone, 206.

Centronyx bairdi, $5 \%$.

Cervus canadensis, 168.

Chotura pelasgia, 66.

Chelopus mühlenbergii, 56.

Chewink. (See Towhee Finch.)

Chipping sparrows (Spizella socialis), 21.

Clam, hard or round. (See Quahaug.)

Cliona sulphurea, 149.

Coiling, tendency towards, in mollusks, $11 \%$.

Conch-shells, 137, 232.

'Coon oysters. (See Ostrea virginiana.)

Coot, eating star-fishes, 136.

Copperhead (Ancistrodon contortrix), 91, 95.

Cowry (Cypraa moneta), $22 \%$.

Crab, common shore, 147.

" in the oyster, 148.

" soft-shelled, 147.

“ the blue, 147.

Crepidula fornicata, 118.

Crotalidoe, origin of name, 90.

Crotalus admanteus, 92.

" confluentus, 93.

" horridus, 90.

" kirtlandi, 92.

" miliaria, 92.

Curiosity in small animals, 97, 100. 
Cuttle-fishes, 161.

" edible, of Puget Sound, 165.

Cyprcea moneta, $22 \%$.

Cystophora cristata, 186, 188, 191.

Deer in winter, 74 .

" the eastern (Cariacus virginianus), 74 .

Deer, the mule (Cariacus macrotis), 74 .

Dendr'eca cstiva, 21.

Dentalium-money, 244.

Devil-fishes, a practical view of, 161-167.

Didelphys virginiana, 69.

Distribution, local, of animal life, 55 .

Dogs used in hunting seals, 192.

Donax variabilis, 156.

Dove (Zenaidura carolinensis), note of, 26 .

Dredging apparatus, 84.

Drill, the, 145.

Drum-fish (Pogonias chromis), 142.

Echo, myth of, the, 91.

Eggs of oyster, 113.

Elk (Cervus canadensis), 168.

Embryology of oyster, 114. " of star-fishes, 125.

Erethizon dorsatus, 73.

Erignathus barbatus, 186.

Eskimo method of seal-hunting, 190, 194.

Fascination accounted for, 28, 95 .

Field-naturalist, a model, 54.

Fishes as oyster enemies, 142. " in winter, 63.

Five-finger. (See Star-fish.)

Five, significance of, among Radiates, 120.

Floe-rat. (See Ringed Seal.)

Flounders, color changes in, 82. " reared from eggs, 87 .

Food of seals, 196.

Fright, stupefaction from, 29, 37, 96.

Frog, tree (Hyla versicolor), 15, 64.

" wood (Rāna temporaria, var. sylvati$c a), 15,65$.

Fulgur carica, 137, 138, 232.

F'ulica americana, 136.

Fungus in caves, 216.

" in winter, 49.

Geology of caves, 203-220.

Goldfinch (Astragalinus tristis), 15.

Graybeard hydroids, 149.
Ground-squirrels, 70.

Gulf Stream, effect of, on animal life, 77, 87.

Gulls, burgomaster, 192.

Gulo luscus, 76.

Haliotis family, 221-226, 245 .

" Chinese uses of, 222, 224.

"Indian uses of, 226, 245.

Harbor-seal, 182.

Hares in winter, 69.

Harp-seal, 186, 188, 191.

Hawok. (See Shell-money.)

Herons when a heronry burns, 29.

Heterodon platyrhinus, 101.

Hiqua. (See Shell-money.)

Hirundo erythrogastra, 26.

Hog-nose snake (Heterodon platyrhinus), 101.

Hooded seal, 186, 188, 191.

Hummingbirds, 2\%.

Hyla versicolor, 15.

Ilyanassa obsoleta, 146.

Indian beads. (See Shell-money.)

“ methods of boring, 234, 243 .

“ money and trade, 226-247.

Infusoria, 58.

Ink from cuttle-fishes, 166.

Insects in winter, 58.

Joree. (See Towhee Finch.)

Kassigiak. (See Harbor-seal.)

King-bird (Tyrannus carolinensis), $2 \%$.

King-snake (Ophiobolus sayi), 102.

Kol-kol. (See Shell-money.)

Laboratory, Agassiz's sea-side, 78.

Larus glaucus, 192.

Limpet, the slipper (Crepidula fornicata), 118.

Linyphia weyeri, 215 .

Lizards in winter, 65.

Loligo pallida, 161.

" pealei, 161.

“ sagittata, 164.

“ vulgaris, 165 .

Lunatia heros, 145.

Luray caverns, 203-216.

Makira money, 229.

Malayta money, 229.

Mangrove, characteristics of, 151. 


\section{INDEX.}

Mangrove key, history of a, 150-155.

Massasauga (Caudisona tergemina), 91.

Medicinal qualities of the rattlesnake, 107.

Melospiza melodia, 21.

Merula migratorius, 26.

Mice and rats, wild, 70.

Migrations of seals, 188, 195.

Moccasin (Ancistrodon piscivorus), 91, 94.

Mockingbirds and rattlesnake, 30.

Modiola plicatula, 146.

Mole (Scalops aquaticus), 72.

Mollusks as oyster enemies, 119-146.

Moths, sphinx, 61.

Mussels as oyster pests, 146.

Myriapods of caves, 215.

Neosorex, 32, 37.

Netsick. (See Ringed Seal.)

Ocean, distribution of life in, 77.

Octopus granulatus, 161, 166.

" punctatus, 165.

Ommastrephes illecebrosa, 161.

Operculum, use of, 117.

Ophiobolus sayi, 102.

Ophiurans, 130.

Opossum (Didelphys virginiana) in winter, 69. Ormer shell. (See Haliotis.)

Ortyx virginianus, 175.

Ostrea virginiana, 113.

Oven-bird. (See Water-thrush.)

Ovulum angulosum, 228.

Oyster (Ostrea virginiana), 113.

“ enemies of, 119-149.

“ on the Florida coast, 150.

Pagophilus grœnlandicus, 186.

Partridge. (See Quail.)

Pearl images of Buddha, 224.

Pedicellariæ of star-fish, 120.

Periwinkles and oyster pests, 137-149.

Phitampetus labrusco, 60.

Phoca fotida, 186.

Phoca vitulina, 182, 187.

Pinnotheres ostreum, 148.

Pipilo erythropthalmus, 30.

Pogonias chromis, 142.

Pompano (Trachynotus carolinus), food of, 160.

Pompano-shells, the, 156-160.

Porcupine (Erethizon dorsatus), 73.
Pugnacity in small animals, 36.

Purpura lapillus, 145.

Quadrupeds in winter, 68.

Quahaug (Venus mercenaria), 232, 239.

Quail, the American (Ortyx virginianus), 175.

Rails, when flooded out, 30.

Rana sylvatica, 15, 65.

Rattle of rattlesnake, purpose of, 97.

Rattlesnakes (see Crotalus), 90-112.

Reptiles, expression in, 101.

Ringed seal, 186, 188.

Robin (Merula migratoria), 26.

Sandpiper, spotted (Tringoides macularius), 41.

Saxidomus auratus, 244.

Scalops aquaticus, 72.

Scent, retention of, in quail, 179.

Sciurus carolinensis, 72.

" 7udsonius, 72.

Sea-ear. (See Haliotis.)

Sea-grapes (eggs of squid), 146.

Sea-necklaces, 139.

Sea-stars. (See Star-fish.)

Seal, bearded (Erignathus barbaitus); 188.

" common. (See Harbor-seal.)

" the Greenland. (See Harp-seal.)

" the harbor (Phoca vitulina), 182.

" the harp (Pagophilus gronlandicus), 186, $188,199$.

Seal, the hooded (Cystophora cristata), 186, $188,191$.

Seal, the ringed (Phoca fotida), 186, 188.

Seals, former abundance of, 182 .

Sepia, or India ink, source of, 166.

Serpulidxe on oysters, 149, 152.

Sertularia argentea, 149.

Shell-heaps in Florida, 154, 155.

Shell-money of primitive races, 227-24\%.

$$
\text { " } \quad \text { of Pacific coast, } 240 \text {. }
$$

Shells as a defence, 116, 128.

Shrew, etymology, 38 .

“. long-tailed, 32 .

“ short-tailed (Blarina brevicauda), 33.

Sialia sialis, 26.

Sizurus anericapillus, 47.

" motacilla, 44, 47.

" novins, 43,46 . 
Six yeux. (See Haliotis.)

Snails in winter, 61.

Snakes in winter, 66 .

Song-sparrow (Melospiza melodia), 21.

Sorex, 32.

Soricida, 32, 72.

South Sea Islands, primitive money of, 228.

Sparrow, Baird's (Centronyx bairdii), 57.

$$
\begin{aligned}
& \text { " chipping, } 21 . \\
& \text { " song, 21, 22. }
\end{aligned}
$$

Spiders, water, 58, 62.

Spirostrephon copei, 215.

spizella socialis, 21.

Sponges, fresh-water, 58.

“ parasitic on oysters, 149.

Square-flipper. (See Bearded Seal.)

Squids as oyster enemies, 146.

“ and cuttles as food, 164.

Squirrel, gray (Sciurus carolinensis), 17, 70, 72.

Squirrel, red (Sciurus hudsonius), 71.

" rescuing a young, 17.

Stalactites, formation of, $209,219$.

Star-fish and their mischief, 119-136.

Sting-ray, stingaree, 144.

Swallow, barn (Hirundo erythrogastra), 26.

Swallows, hibernation of, 66 .

Swallowing of young snakes by their mother, 91.

Swamp-robin. (See Towhee Finch.)

Swift, chimney (Chatura pelasgia), 66.

Sword-fish attacking seals, 186, 187 .

Sycotypus canaliculatus, 137, 141, 232.

Symbolism of serpents, 110.

Thryothorus ludovicianus, 22, 27 .

Toads in winter, 64.

Topics in natural history for social study, 53. Torpidity, animal, 61, 66.

Tortoises and turtles in winter, 65.

Towhee finch (Pipilo erythropthalmus), 30.

Trachynotus carolinus, 160.

Tree-toad. (See Tree-frog.)
Tyingoides macularius, 41, 43.

Tritia trivitata, 146.

Turtle, Mühlenberg's (Chelopus mühlenbergii) 56.

Tusk-shells. (See Dentalium).

Tyrannus cas'olinensis, 27.

Ullo. (See Shell-money.)

Urosalpinx cinerea, 145.

Tanessa antiopa, 61 .

" progne, 61.

Venus mercenaria, 232.

Venus's ear. (See Haliotis.)

Vitrina snails, 62.

Wagtail. (See Water-thrush.)

Wampum. (See Shell-money.)

Wapiti. (See Elk.)

Warbler, yellow (Dendroeca cestiva), 21.

Water-thrush, golden-crowned (Siurus auricapillus), 47.

Water-thrush, large-billed (Siurus motacilla), $44,47$.

Water-thrush, Louisiana, 44, 47.

“ New York, 48, 46.

" small-billed (Siurus novius),

43,46 .

Weasels and martens, 76.

Wedge-shells. (See Donax.)

Winkle, or wrinkle, 137.

Winter, animals of, 58-76.

" effect of, on fur and plumage, 76.

“ quails in, 180.

“ work for naturalists, 49.

Wolverine (Gulo luscus), 76.

Worms, 58.

Wren, Bewick's (Thryothorus bewickii), 56 . "Carolina (Thryothorus ludovicianus), 22-26, 27.

Yellow warbler, 21.

Zenaidura carolinensis, 26.

Zygonopus vohitei, 215. 


\section{INTERESTING WORKS}

\section{ON \\ NATURAL HISTORY.}

Biart's Adventures of a Young Naturalist.

The Adventures of a Young Naturalist. By Lucier Biart. Edited and Adapted by Parier Gillmore. With 117 Illustrations. 12mo, Cloth, $\$ 175$.

\section{Gillmore's Prairie and Forest.}

Prairie and Forest : a Description of the Game of North America, with Personal Adventures in their Pursuit. By PARker Gidlmore. Illustrated. $12 \mathrm{mo}$, Cloth, $\$ 150$.

\section{Darwin's Voyage of a Natul'alist.}

Voyage of a Naturalist. Journal of Researches into the Natural History and Geology of the Countries visited during the Voyage of H.M.S. Beagle round the World. By Charles Darwin, M.A., F.R.S. 2 vols., $12 \mathrm{mo}$, Cloth, $\$ 200$.

What Mr. Darwin Saw.

What Mr. Darwin Saw in his Voyage round the World in the Ship Beagle. With Illustrations. 8vo, Cloth, \$3 00.

\section{Greenwood's Wild Sports of the World.}

Wild Sports of the World: a Book of Natural History and Adventure. By J AMes Greenwood. Illustrated. Crown 8vo, Cloth, $\$ 250$.

\section{Hooker's Natural History.}

Natural History. For the Use of Schools and Families. By WortIington Hooker, M.D. Nearly 300 Ill's. 12mo, Half Leather, 90 cts.

\section{Hooker's Child's Book of Nature.}

The Child's Book of Nature, for the Use of Families and Schools : intended to aid Mothers and Teachers in Training Children in the Observation of Nature. By Worthington Hooker, M.D. Illustrated. Small 4to, Half Leather, $\$ 100$.

\section{Pike's Sub.'Tropical Rambles.}

Sub-Tropical Rambles in the Land of the Aphanapteryx : Personal Experiences, Adventures, and Wanderings in and about the Island of Mauritius. By Nicholas Pike. Illustrated. 8vo, Cloth, \$3 50.

\section{Jaeger's North A merican Insects.}

The North American Insects; with Numerous Illustrations. By Professor J 
Kingsley's West Indies.

At Last: a Christmas in the West Indies. By Charles Kingsuer. Illustrated. $12 \mathrm{mo}$, Cloth, \$1 50 .

Lewes's Studies in Animal Life.

Studies in Animal Life. By Geo. H. Lewes. Illustrated. 12mo, Cloth, $\$ 100$.

Smiles's Scotch Naturalist.

Life of a Scotch Naturalist: Thomas Edward, Associate of the Linnæan Society. By Samdel Smiles. Portrait and Ill's. 12mo, Cloth, \$1 50.

\section{Spry's Cruise of the "Challenger."}

The Cruise of Her Majesty's Ship Challenger. Voyages over many Seas, Scenes in many Lands. By W. J. J. SpRr, R.N. With Map and Illustrations. Crown 8vo, Cloth, ${ }^{\star} 200$.

\section{Thomson's Voyage of the "Challenger."}

The Atlantic: An Account of the General Results of the Voyage of the Challenger during the Years 1873 and 1876. By Sir C. W צvilue Thомson, F.R.S. With a Portrait of the Author, Colored Maps, Temperature Charts, and Illustrations. 2 vols., 8vo, Cloth, $\$ 1200$.

\section{Wallace's Island Life.}

Island Life; or, The Phenomena of Insular Faunas and Floras, with their Causes. Including an entire revision of the Problem of Geological Climates. By Alfred Russer Wallace. With Illustrations and Maps. 8vo, Cloth, $\$ 400$.

\section{Wallace's Geographical Distribution of Animals.}

The Geographical Distribution of Animals. With a Study of the Relations of Living and Extinct Faunas, as Elucidating the Past Changes of the Earth's Surface. By Alfired Russel Wallace. With Maps and Illustrations. 2 vols., 8 vo, Cloth, \$10 00 .

\section{Treat's Chapters on Ants.}

Chapters on Ants. By Mary Treat. 32mo, Paper, 20 cents; Cloth, 35 cents.

\section{White's Selborne.}

Natural History of Selborne. By Rev. GiLbert WHite. Illustrated. $18 \mathrm{mo}$, Cloth, 75 cents.

\section{Rev. J. G. Wood's Works.}

Homes without Hands : being a Description of the Habitations of Animals, classed according to their Principle of Construction. Illustrated. 8vo, Cloth, \$4 50; Sheep, \$5 00; Roan, \$5 00; Half Calf, \$6 75.

Man and Beast, Here and Hereafter. Illustrated by more than 300 Original Anecdotes. $8 \mathrm{vo}$, Cloth, \$1 50.

The Illustrated Natural History. With 450 Engravings. 12mo, Cloth, \$1 0 . 
Bush's Reindeer, Dogs, and Snow.shoes.

Reindeer, Dogs, and Snow-shoes: a Journal of Siberian Travel and Explorations made in the Years 1865-'67. By RICHARD J. BusH. Illustrated. Crown 8vo, Cloth, \$3 00.

\section{Orton's Comparative Zoology.}

Comparative Zoology, Structural and Systematic. By James OrTon, $\mathrm{Ph} . \mathrm{D}$. With 350 Illustrations. Revised Edition. Crown 8vo, Cloth, $\$ 180$.

\section{Orton's Andes and the Amazon.}

The Andes and the Amazon; or, Across the Continent of South America. By James Orton, Ph.D. Third Edition, Revised and Enlarged, containing Notes of a Second Journey Across the Continent from Pará to Lima and Lake Titicaca. With Maps and Ill's. 8vo, Cloth, \$3 00.

\section{Ernest Ingersoll's Works.}

Knocking Round the Rockies. Mllustrated. 8vo, Cloth, $\$ 200$.

Friends Worth Knowing, Glimpses of American Natural History. Illustrated. Square 16mo, Cloth, $\$ 100$.

Country Cousins. Short Studies in the Natural History of the United States. Illustrated. 8vo, Cloth. (Just Ready.)

\section{Gibson's Camp Life in the Woods.}

Camp Life in the Woods; and the Tricks of Trapping and Trap Making. Containing Comprehensive Hints on Camp Shelter, Woodland Beds, Boat and Canoe Building, Trappers' Food, \&c. With Extended Chapters on the Trapper's Art; Detailed Instructions for the Capture of all Fur-Bearing Animals; Valuable Recipes for the Curing and Tanning of Fur Skins, \&c. By W. Hamilton Gibson, Author of "Pastoral Days." Illustrated by the Author. 12mo, Cloth, $\$ 100$.

Wolf's Wild Animals.

The Life and Habits of Wild Animals. Illustrated from Designs by Joseph Worf. With Descriptive Letter-press by Daniel Giraud Elliot. 4to, Cloth, Gilt Edges, $\$ 500$.

\section{Jones's South Pacific.}

Life and Adventures in the South Pacific. By Jones. Illustrated. $12 \mathrm{mo}$, Cloth, \$1 50 .

Hunting Adventures on Land and Sea. By Thos. W. Knox. Part I. The Young Nimrods in North America, Copiously Illustrated. 8vo, Cloth, $\$ 250$.

Part II. The Young Nimrods Around the World. Copiously Illustrated. 8vo, Cloth, $\$ 250$.

\section{Davis's Nimrod of the Sea.}

Nimrod of the Sea; or, The American Whaleman. By William M. Davis. Illustrated. $12 \mathrm{mo}$, Cloth, $\$ 200$. 


\section{Murphy's Sporting Adventures in the Far West.}

Sporting Adventures in the Far West. By J. M. Murpux. Illustrated. $12 \mathrm{mo}$, Cloth, $\$ 150$.

\section{Morris's Dogs and their Doings.}

Dogs and their Doings. By Rev. F. O. Morris, B.A. Illustrated. Square 8vo, Cloth, Gilt Sides, \$1 75 .

\section{Rennie's Natural History of the Elephant.}

Natural History of the Elephant, as he exists in a Wild State, and as he has been made subservient, in Peace and in War, to the Purposes of Man. By Prof. James Rennie. Illustrated. 18mo, Cloth, 75 cents.

\section{Rennie's Natural History of Quadrupeds.}

Natural History of Quadrupeds. By Prof. James Rennie. Illustrated. $18 \mathrm{mo}$, Cloth, 75 cents.

\section{Children's Natural History Picture $\cdot$ Books.}

Square 4to, Cloth, 300 pages each, Illustrated, \$1 50 each.

Picture-Book of Sagacity of Animals, - Picture-Book of Birds,Picture-Book of Quadrupeds and other Mammalia.

\section{Paul B. Du Chaillu's Works.}

A Journey to Ashango-Land, and Penetration into Equatorial Africa. Illustrated. 8vo, Cloth, \$5 00; Sheep, \$5 50; Half Calf, \$7 25.

Stories of the Gorilla Country. Illustrated. 12mo, Cloth, \$1 50.

Wild Life under the Equator. Illustrated. 12mo, Cloth, \$1 50.

Lost in the Jungle. Illustrated. 12mo, Cloth; $\$ 150$.

My Apingi Kingdom: With Life in the Great Sahara, and Sketches of the Chase of the Ostrich, Hyena, \&c. Illustrated. 12mo, Cloth, \$150.

The Country of the Dwarfs. Illustrated. 12mo, Cloth, \$1 50.

The Land of the Midnight Sun, Summer and Winter Journeys through Sweden, Norway, luapland, and Northern Finland. Map and I1lustrations. 2 vols. 8 vo, Cloth, $\$ 750$; Half Calf, $\$ 1200$.

\section{Hallock's Fishing 'Tourist.}

'The Fishing Tourist: Angler's Guide and Reference Book, By Charles HaLLOCK. Illustrated. Crown 8vo, Cloth, $\$ 200$.

Published by HARPER \& BROTHERS, New York. 





